\title{
VALORES AMBIENTAIS E
}

DESENVOL VIMENTO TURÍSTICO: UM

ESTUDO DE CASO DO DISTRITO DE SÃO

JORGE EDOPARQUE NACIONAL DA

CHAPADA DOS VEADEIROS

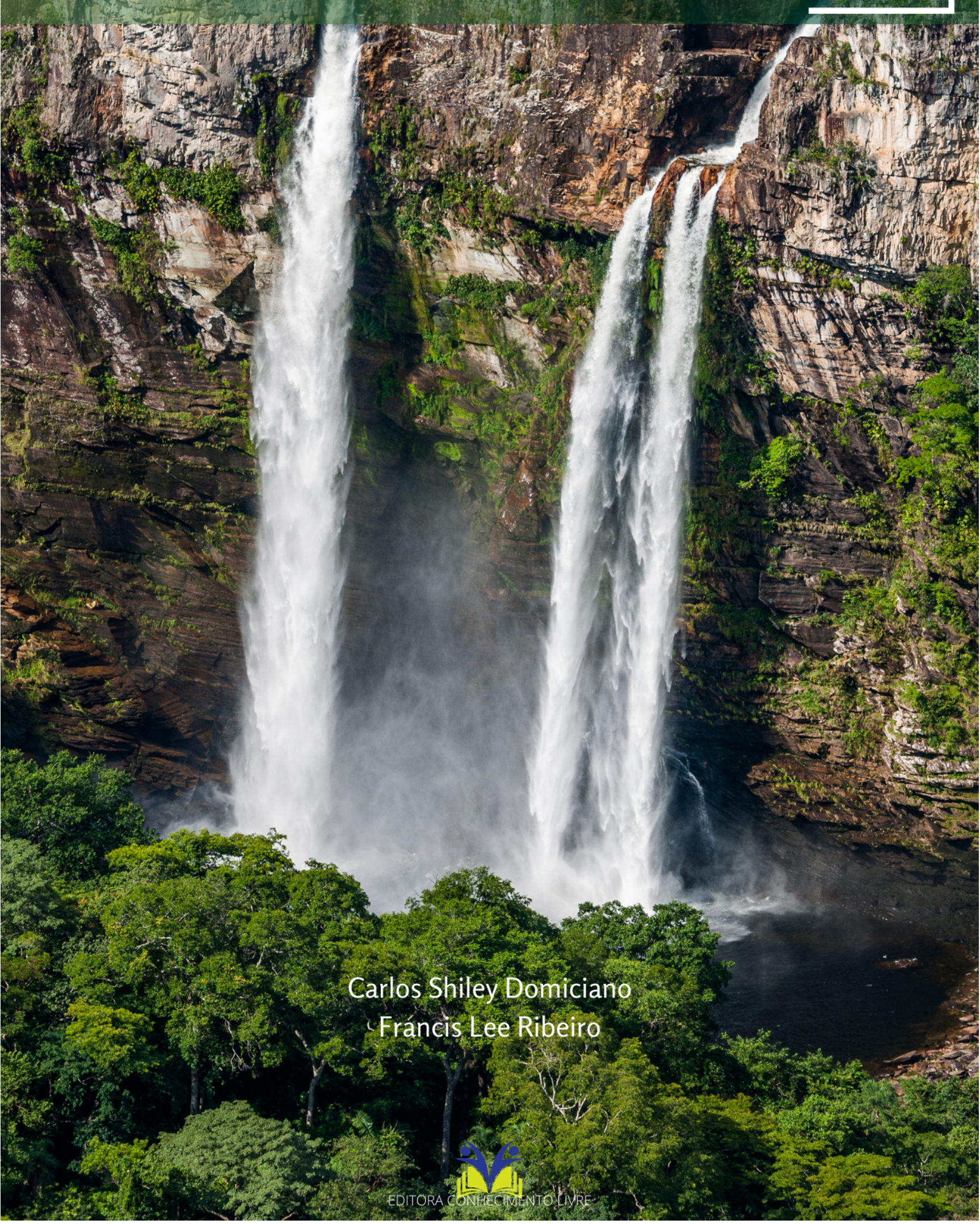


Carlos Shiley Domiciano

Francis Lee Ribeiro

VALORES AMBIENTAIS E DESENVOLVIMENTO TURÍSTICO: UM ESTUDO DE CASO DO DISTRITO DE SÃO JORGE E DO PARQUE NACIONAL DA CHAPADA DOS VEADEIROS

$1^{\text {a }}$ ed.

Piracanjuba-GO

Editora Conhecimento Livre

Piracanjuba-GO 
$1^{\mathrm{a}} \mathrm{ed}$

\section{Dados Internacionais de Catalogação na Publicação (CIP)}

Domiciano, Carlos Shiley

D671V VALORES AMBIENTAIS E DESENVOLVIMENTO TURÍSTICO: UM ESTUDO DE

CASO DO DISTRITO DE SÃO JORGE E DO PARQUE NACIONAL DA CHAPADA DOS

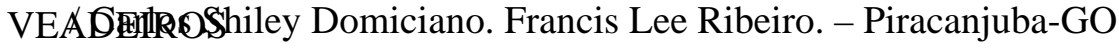

Editora Conhecimento Livre, 2021

190 f.: il

DOI: $10.37423 / 2021$. edcl 278

ISBN: 978-65-89955-12-2

Modo de acesso: World Wide Web

Incluir Bibliografia

1. chapada-dos-veadeiros 2. valoração 3. desenvolvimento-turístico 4. custo-de-viagem 5. valores I.

Domiciano, Carlos Shiley II. Ribeiro, Francis Lee III. Título

CDU: 333.72

https://doi.org/10.37423/2021.edc1278

O conteúdo dos artigos e sua correção ortográfica são de responsabilidade exclusiva dos seus respectivos autores. 


\title{
EDITORA CONHECIMENTO LIVRE
}

\section{Corpo Editorial}

\author{
Dr. João Luís Ribeiro Ulhôa \\ Dra. Eyde Cristianne Saraiva-Bonatto \\ Dr. Anderson Reis de Sousa \\ MSc. Frederico Celestino Barbosa \\ MSc. Carlos Eduardo de Oliveira Gontijo
}

$\underline{\text { MSc. Plínio Ferreira Pires }}$

Editora Conhecimento Livre

Piracanjuba-GO 
VALORES AMBIENTAIS E DESENVOLVIMENTO TURÍSTICO: UM ESTUDO DE CASO DO DISTRITO DE SÃO JORGE E DO PARQUE NACIONAL DA CHAPADA DOS VEADEIROS
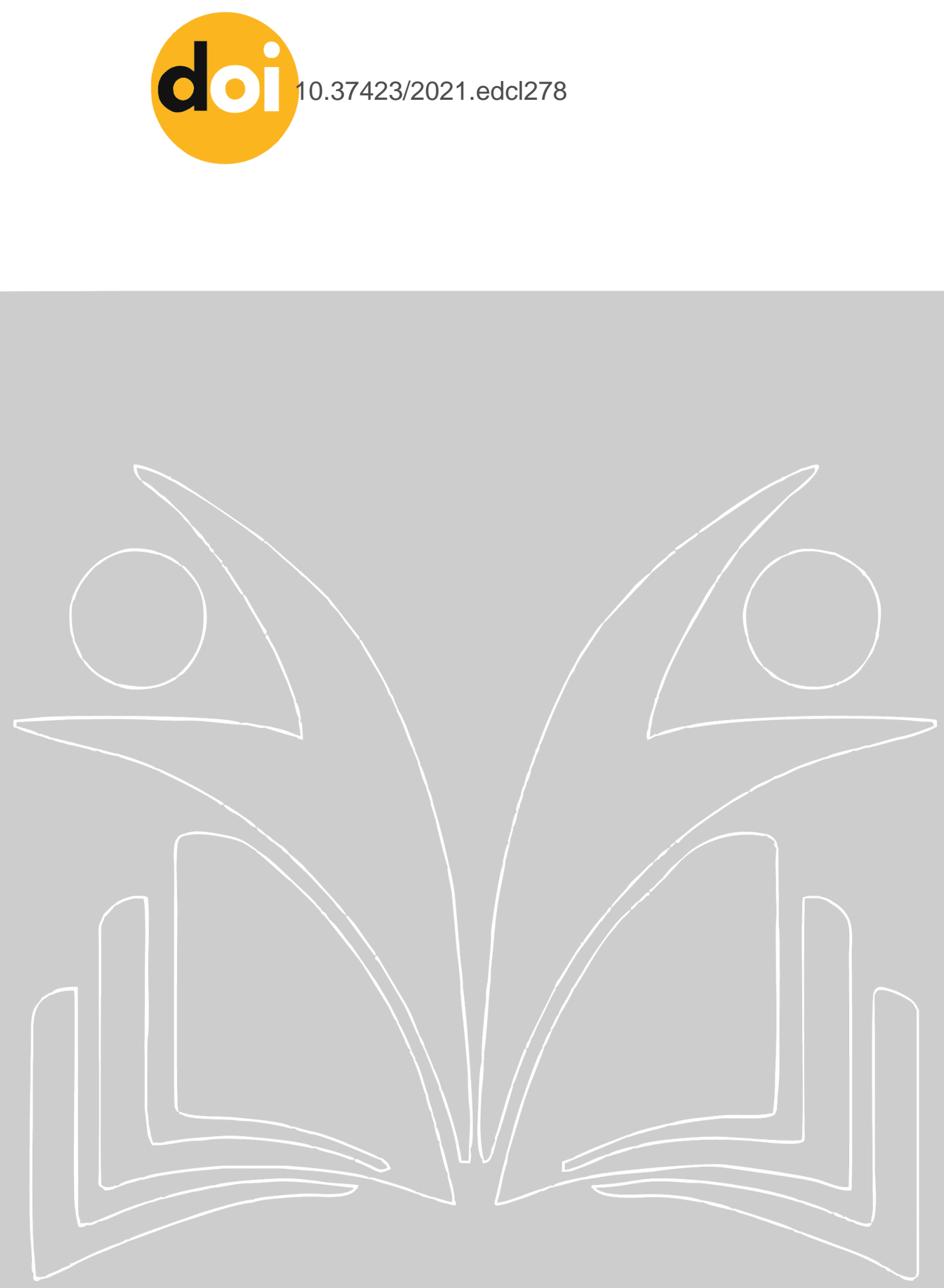


\section{Sumário}

INTRODUÇ̃̃o

1 OS CAMINHOS DA PESQUISA 11

1.1 ASPECTOS METODOLÓGICOS. 11

1.2 CARACTERIZAÇÃO DA ÁREA DE ESTUDO 16

1.2.1 O MUNICÍPIO DE ALTO PARAíSO DE GOIÁS E O DISTRITO DE SÃO JORGE 16

1.2.2 - O PARQUE NACIONAL DA CHAPADA DOS VEADEIROS. 20

1.3 FOTOGRAFIAS DO PNCV, ATRATIVOS DO ENTORNO E DO DISTRITO DE SÃO JORGE FEITAS PELO AUTOR EM JULHO DE 2012 25

2 DESENVOLVIMENTO RURAL E A CONSERVAÇÃO AMBIENTAL 34

2.1 NOVOS VALORES PARA O RURAL .34

2.2 AS UNIDADES DE CONSERVAÇÃO E AS RURALIDADES CONTEMPORÂNEAS 36

2.3 AS IMPLICAÇÕES DA CRIAÇÃO DE UMA UNIDADE DE CONSERVAÇÃO EM UM TERRITÓRIO .50 3 CONTEXTUALIZAÇÃO HISTÓRICA DA CHAPADA DOS VEADEIROS: (IM)POSSIBILIDADES E POTENCIALIDADES. 59

3.1 DA TERRA DE GARIMPO A PARQUE .59

3.2 A CRIAÇÃO DO PARQUE NACIONAL DA CHAPADA DOS VEADEIROS .68

3.3 E AGORA? 90

4 VALORAÇÃO DOS BENS E SERVIÇOS DO PARQUE NACIONAL DA CHAPADA DOS VEADEIROS E ENTORNO 98

4.1 VALOR E VALORAÇÃO: UM CONSENSO ENTRE O ECONÔMICO E SOCIOAMBIENTAL .98

4.2 VALORAÇÃO AMBIENTAL 104

4.2.1 MÉTODOS E TÉCNICAS DE VALORAÇÃO AMBIENTAL. 108

4.2.2 MÉTODO DO CUSTO DE VIAGEM. 114

4.3 VALORIZAÇÃO TURÍSTICA: PARA ALÉM DO VALOR MONETÁRIO 120

4.4 RESULTADOS E DISCUSSÕES 124

4.4.1 PESQUISA PILOTO 124

4.4.1.1 RESULTADOS DA PESQUISA PILOTO 125 


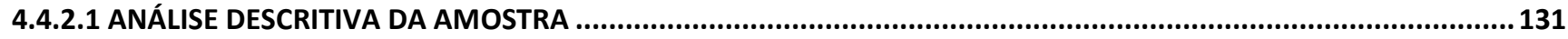

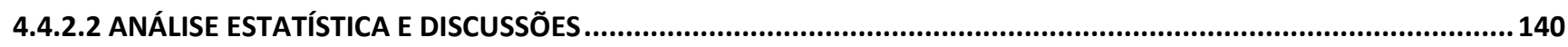

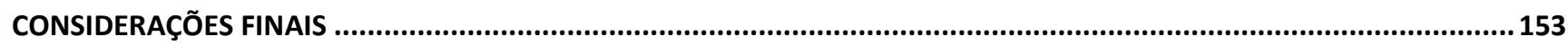

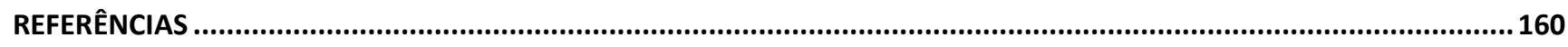

APÊNDICE A: ROTEIROS DAS ENTREVISTAS SEMI-ESTRUTURADAS ................................................................172

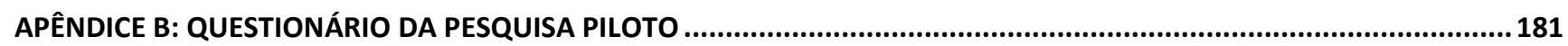

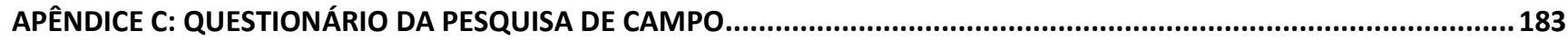

APÊNDICE D: CÁLCULO PARA DETERMINAR O TAMANHO DA AMOSTRA DA PESQUISA DE CAMPO ...........................185

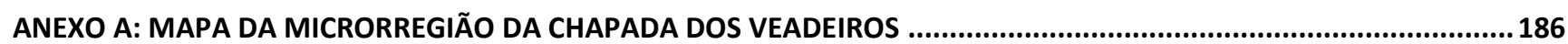

ANEXO B: ÁREAS DO PNCV CONFORME OS DECRETOS DE SUA REGULAMENTAÇÃO ............................................187 


\section{INTRODUÇÃO}

O ser humano, como todo ser vivo, busca no ambiente os recursos de que precisa para sobreviver. Essa exigência de sempre estar em contato com o meio para subsistir cria a chamada relação homemnatureza e se manifesta em vários aspectos: econômico, social, cultural, ambiental.

Desde tempos remotos, essa relação tem um caráter exploratório e, na medida em que a população vai aumentando, os meios tecnológicos vão se sofisticando, o homem passa a sobrecarregar mais as regiões naturais e a sua capacidade de se recompor, comprometendo o seu equilíbrio. Assim, o consumo humano, que aumenta a cada dia, faz surgir os problemas ambientais, ao desregular a estrutura do meio ambiente, ao passo que avança sobre as áreas naturais, extinguindo espécies e esgotando os recursos que garantem a sua sobrevivência.

Em virtude desse processo, surge então a necessidade de se resguardar tais recursos frente ao seu crescente consumo e todas as formas de intervenção descontroladas por parte do homem. Dessa forma, institucionaliza-se a criação das Unidades de Conservação (UC). Dentre estas UC, destacam-se os Parques Nacionais (PARNA), que além de garantir a conservação e manutenção da biodiversidade e dos seus bens e serviços, preservando o patrimônio genético de espécies, permitem a realização de atividades de pesquisa, educação ambiental e de turismo.

Tais UC, ao serem investidas na proteção da biodiversidade e dos recursos naturais de um determinado bioma, ou de parte deste, encerram em si alguns valores que vão desde a esfera econômica até a sociocultural das regiões onde se localizam.

Esses valores podem se refletir economicamente, quando do uso de um bem ou serviço, como o uso direto de suas amenidades, por meio do lazer e recreação, ou gerar renda, quando da contratação de um guia local. Pode também se encerrar em um princípio ativo, encontrado em uma espécie de planta, existente nessa UC, que ainda não foi descoberto e na qual a planta está aí preservada. Ou ainda, nas formas viventes que na localidade se encontram e possuem seu valor pelo simples fato de existir, como uma manifestação de vida.

As UC, além do seu papel na conservação da biodiversidade e dos bens e serviços que proporcionam, podem também constituir-se em elementos de referência de desenvolvimento das comunidades onde estão instaladas, obtendo, dessa forma, o reconhecimento de sua importância. 
Nessa perspectiva, trata-se de encontrar um caminho que busque a sustentabilidade das regiões onde se situam, garantindo qualidade de vida das pessoas dessas localidades, conforme assegurou Leff (2009, p. 193), em que se torna necessário "repensar o ambiente como um potencial para o desenvolvimento, ou seja, construir um novo paradigma produtivo que integre a natureza e a cultura como forças produtivas".

O motivo da escolha do Parque Nacional da Chapada dos Veadeiros (PNCV) e das imediações do Distrito de São Jorge como objeto desse estudo reside no fato de que a região se destaca entre os exemplos de rico patrimônio natural do estado de Goiás e do país. A mesma apresenta-se como uma das mais bem preservadas áreas do cerrado brasileiro e representa a maior área de vegetação nativa de um tipo específico (cerrado rupestre) do bioma no território goiano, ocorrendo em altitudes superiores a 900 metros, sobre afloramentos rochosos e com forte endemismo e, segundo Oliveira (2007), compreende apenas $3 \%$ de todo o cerrado brasileiro, sendo que desse percentual, quase a totalidade (cerca de 98\%) encontra-se na Chapada dos Veadeiros.

De acordo com o Plano de Manejo do PNCV, a preservação do cerrado de altitude com suas "chapadas ainda intactas", é de fundamental importância para a proteção das reservas hídricas da área do alto curso do Rio Tocantins, bem como para a realização de atividades de ecoturismo, recreação e educação ambiental em áreas naturais, não só para a população das cidades próximas e do Centro Oeste, mas também para aquela de diferentes pontos do país (BRASIL, 2009).

A região, pelas suas características topográficas, com relevo acidentado, e edafológicas, com solos rasos e pedregosos, não foi utilizada para agricultura intensiva que tomou conta do cerrado em geral, registrando-se uma incipiente prática agrícola de subsistência e de uma pecuária extensiva por parte das pessoas que aí habitavam.

Antes, porém, da instalação do PNCV, na região do Distrito de São Jorge, as pessoas se ocupavam da atividade garimpeira de cristais de rocha de quartzo, material este que era extraído manualmente, com o uso de ferramentas simples (picaretas, pás, marretas, ponteiros, etc.). A atividade apresentou seu auge de produção nas décadas de 1940 e 1950, em picos coincidentes com a II Guerra Mundial e a Guerra da Coreia, por ser utilizado na indústria bélica de telecomunicação. A relação das pessoas com esse ambiente era de exploração, uma visão utilitária, de ganho imediato, sem a preocupação em preservar aquele meio, visto que a atividade era altamente depredatória. 
Com a instalação do Parque Nacional, houve uma reconfiguração das práticas das pessoas na localidade. Primeiramente, um período de confrontos e conflitos, envolvendo os garimpeiros e proprietários de terras de um lado, e de outro, o Estado, no início por intermédio do Ministério da Agricultura (MA) e depois pelo Instituto Brasileiro de Desenvolvimento Florestal (IBDF) e o Instituto Brasileiro do Meio Ambiente e dos Recursos Naturais Renováveis (IBAMA), até que se chegou a um consenso, de que as atividades da antiga vila se voltassem para a atividade turística, que emanava do Parque.

Nesse momento, a visão das pessoas se voltou para o aspecto da conservação dos bens e serviços que o Parque e o seu entorno possuíam, pois estes se transformaram em elementos mais estáveis para proporcionar renda, não somente aos garimpeiros, que se tornaram condutores de visitantes (guias), mas também aos proprietários de estabelecimentos comerciais e de serviços como pousadas, restaurantes, bares e aos proprietários de terras, principalmente na Zona de Amortecimento, que viram os recursos naturais de suas propriedades (rios, cachoeiras) transformarem-se em atrativos turísticos.

Ao propiciar a oportunidade desses produtores rurais se ocuparem com uma atividade fora dos meandros da função produtiva agrícola, o PNCV abriu caminho para o desempenho de uma nova função, a da conservação ambiental, inserida na lógica da multifuncionalidade das atividades no espaço rural, em contribuição ao desenvolvimento da região.

A atividade turística proveniente da criação do PNCV atraiu para a localidade os turistas (visitantes), que buscavam no contato com a natureza, na contemplação da beleza cênica do lugar, a formulação de valores diretamente ligados à conservação da natureza. O turismo é um processo de produção social, que envolve trocas, não só no âmbito econômico, mas também no âmbito sociocultural, e esse intercâmbio, de certa forma, interferiu na referência de valores das pessoas da localidade, que por sua vez, passaram a valorizar mais os aspectos ambientais do seu lugar.

O Parque não deixou de ser uma referência econômica para as pessoas da região, pois, como muitos afirmaram em seus relatos, na pesquisa de campo, em ser a principal fonte de renda dos moradores do local, "ser o ganha-pão", como também instituiu na mentalidade das pessoas uma valorização no que diz respeito a manter e conservar aquele ambiente, até mesmo em garantia de seu "sustento". Essa preocupação com o meio ambiente pode ser notada nas palavras de orientação de um condutor de visitantes a um grupo de pessoas que se preparava para realizar um passeio nas trilhas do Parque: "aqui a gente só mata sede, tira foto, deixa pegada e leva saudade". 
Também para os turistas, os ecoturistas - consumidores de paisagens autênticas (LIMA, 1998) - os bens e serviços do PNCV e entorno apresentam seus valores, visto que esse visitante busca numa viagem como essa o aprimoramento do conhecimento, a aproximação e o convívio com outras culturas e a integração com a natureza. Esses valores que os turistas atribuem ao conjunto de bens e serviços de um Parque Nacional relacionam-se aos custos de viagem, que estão dispostos a pagar para usufruir das amenidades desse local, e revelam um valor econômico total, em que se agregam valores monetários, sociais, culturais e ambientais desse passeio.

Nesse aspecto, suscitam-se as seguintes indagações que norteiam a realização desse trabalho:

- As atividades turísticas desenvolvidas no PNCV e seu entorno constituem-se em uma estratégia de desenvolvimento rural para as pessoas da região do Distrito de São Jorge, no âmbito da multifuncionalidade do espaço rural?

- Qual a noção de valores que a comunidade local atribui ao conjunto de bens e serviços ambientais do PNCV e seu entorno?

Quais são os valores que os visitantes atribuem ao conjunto de bens e serviços do PNCV e seu entorno?

Em face dessas questões expostas, surgem as hipóteses para a fundamentação da pesquisa.

- Uma unidade de conservação constitui um elemento de desenvolvimento para as comunidades rurais do seu entorno, ao proporcionar renda para as pessoas por intermédio das atividades turísticas aí praticadas.

- O conjunto de bens e serviços do PNCV e entorno possui valores expressos pelas pessoas da comunidade do Distrito de São Jorge e pelos visitantes-turistas.

Este trabalho analisa um objeto que tem uma perspectiva prática interdisciplinar cujo mote principal passa pela questão ambiental, e busca respostas na área das ciências aplicadas, em disciplinas como a Economia, a Sociologia Rural, o Turismo e outras, que formam um arcabouço teórico com o fim de elucidar as intrincadas relações socioambientais de uma localidade. Como afirmou Leff (2003, p.7): “a complexidade emerge como uma nova racionalidade e um novo pensamento sobre a produção do mundo com base no conhecimento, na ciência e na tecnologia: é o espaço onde se articulam a natureza, a técnica e a cultura".

Nesse aspecto, trabalhou-se um conjunto de metodologias que aliam a temática ambiental à socioeconômica. Primeiramente, fez-se uma análise do contexto histórico do que se sucedeu na 
Chapada dos Veadeiros, e especificamente na região do Distrito de São Jorge, desde a época da garimpagem até os dias atuais, com a atividade turística proveniente da criação do PNCV.

Essa análise respaldou-se em estudos do desenvolvimento rural, uma vez que a região se enquadra nesse aspecto, focando-se na multifuncionalidade do espaço rural, cuja função da conservação ambiental tornou-se a prerrogativa maior, dada a instalação de uma UC na região. Nessa discussão também se mencionou a territorialização dos espaços, que reflete os diversos interesses que envolvem as questões sociais, econômicas, políticas, culturais e ambientais da conservação no Brasil.

Em relação ao turismo que é realizado nas UC, destaca-se a sua importância por ser, em diversos casos, uma das principais fontes de emprego e renda para as populações das localidades onde estão assentadas. Medeiros et al. (2011, p. 6) apontam em um estudo realizado para o Ministério do Meio Ambiente (MMA): “o turismo que dinamiza a economia de muitos dos municípios do país só é possível pela proteção das paisagens proporcionada pela presença das Unidades de Conservação".

Na segunda parte do trabalho, o enfoque passou a ter como eixo propulsor o turismo enquanto um processo de produção social, no intuito de realizar uma valoração, um conceito de natureza econômica, de um ente ambiental, no caso o PNCV, por intermédio da atividade turística desenvolvida pelas pessoas, na junção dos bens e serviços que formam o Parque. Tratou-se da questão da valoração ambiental com base nos custos de viagem dos visitantes que se destinaram ao PNCV e seu entorno, numa determinada época.

Dessa forma, delinearam-se os objetivos para a consecução do trabalho.

Objetivo geral:

- analisar a importância de uma unidade de conservação no contexto do desenvolvimento rural de uma região, identificando os valores que as pessoas (moradores e visitantes) atribuem ao conjunto de bens e serviços do PNCV e seu entorno.

Objetivos específicos:

- detectar as contribuições da unidade de conservação para o desenvolvimento da região a partir da atividade turística por ela proporcionada;

- mensurar e relacionar os custos de viagem dos visitantes do PNCV aos valores atribuídos aos seus bens e serviços; 
- compreender a percepção de valores que a comunidade local possui dos bens e serviços do PNCV e suas imediações.

O intento desse trabalho foi analisar uma região onde se instalou uma UC, que desencadeou um processo de mudanças no uso e nas possibilidades de uso, na apropriação e exploração dos recursos dessa localidade, constituída como um território. Esse fato gerou um conjunto de implicações sociais, econômicas e ambientais, estabelecendo impasses e enfrentamentos entre as pessoas e as instituições envolvidas no processo de instalação do PNCV.

Assim, procurou-se compreender o processo de criação da UC na região, dada a importância que representou e representa na conservação do cerrado no estado de Goiás, e em especial o cerrado de altitude. A sua instalação, de certa forma, interferiu nos modos de vida das pessoas que aí habitavam e possuíam as suas práticas, porém acenou com novas possibilidades para essas mesmas pessoas, por intermédio de um processo de mudança de comportamento com relação ao meio no qual estavam inseridas.

Também vinculada à transformação do plano de conduta dessas pessoas, houve uma reconfiguração de seus valores. Antes da instalação do Parque, o espaço era terra de garimpo, onde para se ganhar alguma coisa era preciso degradar o ambiente. Com o Parque, o entendimento passou a ser outro, o ganho viria com a conservação ambiental, que por sua vez induziria ao turismo.

Entretanto, essa nova atividade, para se estabelecer na localidade, passou a requerer das pessoas uma nova forma de agir, de trabalhar coletivamente para se atingir os seus intentos e se firmarem frente a essa realidade. Houve uma transição dos valores da comunidade residente, que passou a valorizar mais a integridade do ambiente.

A atividade turística significou uma nova oportunidade de reprodução social e econômica, gerando renda e propiciando a exploração dos recursos daquele ambiente, sem contudo deteriorá-lo. E trouxe também os turistas, novos atores em busca do contato com a natureza do conhecimento, do convívio com outras culturas, incutindo na localidade os seus valores ligados à conservação ambiental.

Enfim, esse estudo perpassou por essas nuances com a finalidade de entender se o PNCV, além de cumprir com suas funções de conservação ambiental e da biodiversidade, conseguiu proporcionar à localidade, principalmente ao Distrito de São Jorge, por intermédio do turismo, um marco no desenvolvimento da região, sob a perspectiva da multifuncionalidade. 
Seguindo uma trajetória narrativa, este trabalho apresenta a seguinte estrutura: no Capítulo 1, aborda a questão metodológica utilizada tanto para o estudo de caso relacionado às atividades desenvolvidas pela comunidade do Distrito de São Jorge, quanto para a pesquisa de campo, para apuração do custo de viagem dos visitantes do PNCV e imediações de seu portão de entrada.

No Capítulo 2, apresentou-se um referencial teórico relativo ao desenvolvimento rural, focando no aspecto da multifuncionalidade do espaço rural, principalmente na sua função de conservação ambiental. Também foi utilizado um referencial que trata das questões relacionadas à conservação ambiental no Brasil.

O caso da comunidade do Distrito de São Jorge é analisado no Capítulo 3, em que se destacam as atividades socioeconômicas desenvolvidas na região, desde a época da garimpagem, passando pela criação do PNCV e suas implicações, destacando o surgimento da atividade turística, até os dias de agora, para buscar compreender a importância da UC para a região e a noção de valor que a referida comunidade possui acerca de seu conjunto de bens e serviços.

No Capítulo 4, discutiu-se assuntos referentes à valoração ambiental dos bens e serviços de um sítio natural, para dar suporte ao cálculo de custo de viagem dos visitantes do PNCV, revelando sua disposição a pagar, por esses bens e serviços, na forma de recreação e lazer. Também se fez menção a uma literatura que trata da valorização turística de um determinado atrativo, para mostrar as motivações de um passeio a uma UC. Foram ainda tratados os resultados e as discussões sobre o custo de viagem dos visitantes do PNCV e suas imediações, em que se demonstrou a disposição a pagar das pessoas por uma viagem dessas, relacionando com os valores que atribuem ao conjunto de bens e serviços aí encontrados.

\section{OS CAMINHOS DA PESQUISA}

\subsection{ASPECTOS METODOLÓGICOS}

Esse trabalho tem um caráter qualiquantitativo (DENCKER, 2007), ao ressaltar, por um lado, a natureza socialmente construída de uma realidade (DENZIM e LINCOLN, 2006), no caso a situação dos moradores do Distrito de São Jorge, perscrutando a sua noção de valores relacionados ao ambiente, por intermédio de suas atividades socioeconômicas aí desenvolvidas, e por outro, ao verificar e aferir os custos de viagem dos visitantes do PNCV, em um determinado momento, com intuito de analisar os valores que estes atribuem ao conjunto de bens e serviços aí encontrados e nas imediações de sua entrada. 
Convém esclarecer que a pesquisa de campo foi realizada em duas etapas. Primeiramente, foram coletados os dados junto aos visitantes do PNCV, com aplicação de questionários, e depois foram realizadas as entrevistas com os moradores da localidade e com os agentes institucionais envolvidos no caso. Embora essa tenha sido a ordem cronológica da realização dos trabalhos de campo, na apresentação deste estudo, colocou-se o caso dos moradores do Distrito à frente, para compreender o contexto sócioeconomicoambiental que se passou na região e, em seguida, tratou-se da questão relativa ao custo de viagem dos visitantes.

Para analisar a situação dos moradores do Distrito de São Jorge utilizou-se o estudo de caso. Um estudo de caso possibilita a verificação de como os agentes sociais vivenciam os processos estruturais, o resgate de sua historicidade e a dinâmica das relações sociais.

Segundo Yin (2001, p. 38), o estudo de caso é uma "investigação empírica que investiga um fenômeno contemporâneo dentro do seu contexto da vida real, especialmente quando os limites entre o fenômeno e o contexto não estão claramente definidos".

O mesmo autor salienta que os estudos de casos elucidam generalizações estabelecidas e aceitas, que podem ganhar novos significados quando repetidos em condições diferentes. Também podem se constituir em testes para teorias passíveis de serem comprovadas em várias instâncias, e assim, seus resultados podem estimular novas pesquisas, induzindo a generalizações (YIN, 2001).

Os dados foram coletados com base em depoimentos dos moradores locais e agentes institucionais, combinando técnicas de observação direta e entrevistas. A utilização da oralidade permitiu ampliar o conhecimento dos acontecimentos, nas diversas fases pelas quais passaram essas pessoas, baseandose nos relatos e versões individuais, que somados na trama de um contexto maior propiciaram compreender o que se desenrolou nessa sociedade, por meio da experiência de seus componentes (ALBERTI, 1989), contribuindo para o registro de fatos que eventualmente não tenham sido documentados (HAGUETTE, 2001).

Para tal, utilizou-se uma amostragem não-probabilística e por cotas, por meio da qual se procedeu a uma "seleção dos respondentes para cobrir as cotas, dentro de uma área específica" (DENCKER, 2007, p. 215). Neste caso, as pessoas ligadas diretamente ao turismo praticado no PNCV, como os condutores de visitantes, os proprietários de pousadas e estabelecimentos comerciais, os proprietários de terra com atrativos turísticos e as pessoas que vivenciaram as fases pelas quais passou o Distrito, desde a época da garimpagem até os dias atuais, para poder captar as suas percepções e representações de valor em relação ao conjunto de bens e serviços que o Parque lhes proporcionou e 
proporciona. "Os dados são captados em um contexto fluente de relações. Procura-se compreender a experiência que as pessoas têm, as representações que formam e os conceitos que elaboram" (CHIZOTTI, 2010, p. 84).

O tamanho da amostra seguiu o critério da amostragem por saturação dos objetivos propostos para esse enfoque da pesquisa, quando os dados de um determinado grupo atingiram "a saturação teórica" (FLICK, 2009).

A utilização da técnica da observação tornou possível a avaliação do comportamento das pessoas num dado período, em nível de campo e, a entrevista proporcionou a captação de informações sobre determinado assunto, além de desvelar traços da cultura, crenças e valores dos entrevistados, contribuindo para uma melhor compreensão de sua realidade (LAVILLE e DIONNE, 1999).

Esse procedimento teve o intento de resgatar uma noção de valores que marcaram cada época, que pudessem estar latentes em suas rememorações, “a lembrança diz respeito ao passado, mas se atualiza sempre a partir de um ponto do presente. As lembranças não são falsas ou verdadeiras, simplesmente contam o passado através de quem o vivenciou" (GOLDENBERG, 2000, p. 56).

As entrevistas seguiram um roteiro semi-estruturado (Apêndice A), foram gravadas e posteriormente transcritas, sendo lançadas as perguntas às pessoas, para um direcionamento de seus relatos, numa trajetória que acompanhou o desenrolar de suas experiências no contexto socioeconômico do local.

Ao todo foram realizadas vinte e nove entrevistas com as pessoas da comunidade do Distrito de São Jorge e de Alto Paraíso de Goiás. Desses, quatro eram moradores mais antigos, que vivenciaram as experiências da garimpagem, entre eles, dois chegantes nos anos de 1940; cinco moradores exgarimpeiros e condutores de visitantes; quatro proprietários rurais, com atrativos turísticos em suas propriedades, sendo dois deles ex-garimpeiros; nove donos de estabelecimentos (pousadas, áreas de camping, restaurantes, bares), sendo uma ex-garimpeira e líder comunitária e dois ex-condutores de visitantes, três agentes administrativos do PNCV; dois agentes de órgãos ligados à assistência agropecuária no município (Empresa de Assistência Técnica e Extensão Rural - EMATER; Agência Goiana de Defesa Agropecuária - AGRODEFESA) e dois agentes administrativos, um municipal e outro local.

A análise dos relatos foi corroborada por estudos relativos à região que lhe propiciou uma sustentação dentro de uma conjuntura que permitiu uma melhor compreensão da contextualização histórica, socioeconômica, cultural e ambiental da localidade, sendo utilizadas referências que tratam do 
desenvolvimento do cerrado em geral, alguns estudos relacionados à Chapada dos Veadeiros, e mais especificamente à UC.

Na explanação do caso foram intercalados os depoimentos das pessoas, com apoio dessas referências, para reforçar as análises sobre o seu papel nesse ambiente, antes e depois da instalação do PNCV, focalizando nas suas representações de valores de cada época.

Foram realizadas várias incursões no campo pelo pesquisador, desde 2008 , quando se tomou 0 primeiro contato com o PNCV e o Distrito de São Jorge, por intermédio de visitas técnicas realizadas juntamente com os estudantes dos cursos de Tecnologia em Hotelaria e Planejamento Turístico do Instituto Federal de Educação, Ciência e Tecnologia de Goiás (IFG), estendendo-se até o ano de 2010. Nessas visitas, com duração de quatro dias em média, pode-se observar a realidade da região, o funcionamento do PNCV e o modo de vida das pessoas da localidade, bem como conhecer uma parte de seus aspectos históricos, sociais e culturais.

Em 2011, foi possível passar mais dois períodos de tempo (três e cinco dias respectivamente) na localidade, para o levantamento dos impactos ambientais provocados pelo turismo no PNCV, Distrito de São Jorge e imediações para a realização de um trabalho da disciplina de Oficinas em Análises Ambientais do Programa de Pós-Graduação em Ciências Ambientais (PRPPG/CIAMB).

No ano de 2012, foram mais duas estadias no local, uma para aplicação dos questionários da pesquisapiloto (Apêndice B) desse trabalho aos visitantes do PNCV, com duração de quatro dias, e outra para a realização da pesquisa de campo, em um período de duas semanas, na alta temporada do turismo.

Em 2013, foi desenvolvida a parte operacional do estudo de caso com a realização das entrevistas, em duas oportunidades, com duração de cinco dias cada uma delas, nos meses de março e julho. No mês de março, período coincidente com a baixa temporada do turismo, época em que as pessoas da localidade tiveram uma maior disponibilidade de tempo para tecer os seus relatos, e também propício para a observação do cotidiano do Distrito nesse mesmo período.

O levantamento de dados para o Método do Custo de Viagem (MCV) foi efetivado em uma pesquisa de campo junto aos visitantes do PNCV, com a aplicação dos questionários (Apêndice C), do dia 13 ao dia 27 de julho de 2012, por uma equipe de quatro pessoas, coordenada pelo autor e mais três estudantes de graduação1 da Universidade Federal de Goiás (UFG).

1 Felipe Silva Domiciano, do Curso de Bacharelado em Economia, Gabriela Silva Domiciano, do Curso de Licenciatura em Artes Visuais, e Luana Beatriz Silvéria, do Curso Licenciatura em História. 
A quantidade de questionários aplicada foi definida a partir de uma amostragem probabilística, calculada sobre a média do número de visitantes dos últimos seis anos (2006-2011), conforme dados fornecidos pela administração do PNCV (19.891 pessoas). O cálculo da amostragem definiu um número de 377 questionários (Apêndice $D$ ).

Os questionários foram aplicados aos visitantes que chegavam ao portão de entrada do PNCV, abordados pelos pesquisadores de acordo com a oportunidade de aproximação, isto é, por amostragem de conveniência (DENCKER, 2007), enquanto aguardavam a formação dos grupos para o ingresso no Parque. Uma parte dos questionários foi aplicada aos visitantes após o passeio pelas trilhas do Parque, e outros nas pousadas e áreas de camping do Distrito de São Jorge, com agendamento prévio, antes da entrada.

Esses questionários foram aplicados com as seguintes finalidades: 1 - identificar o perfil socioeconômico dos visitantes, considerando variáveis como a região de origem, sexo, idade, o nível de escolaridade; 2 - o motivo da viagem, o número de pessoas no passeio, o meio de locomoção, o tempo de permanência no local, o pagamento da taxa do condutor de visitantes (que equivale ao valor da entrada do PNCV); 3 - a disponibilidade a pagar, caso o Parque cobrasse uma taxa de ingresso, os gastos efetivos com a viagem e as rendas pessoal e familiar, estipulados em faixas baseadas no salário mínimo vigente no país; 4 - ao final, foram colocadas duas questões de natureza subjetiva, com respostas curtas, com o intuito de sondar, junto aos visitantes, as motivações da viagem e que valores mais atribuíam ao passeio.

A partir dos dados obtidos, em especial aqueles relativos às despesas efetivas com a viagem, procedeu-se à análise dos custos de viagem dos visitantes, relacionando esses gastos com as variáveis que mais interferiram na formação dos mesmos. Buscou-se analisar a disposição a pagar dos visitantes, e também mostrar como esses dispêndios revelam os valores monetários e não monetários que eles atribuem ao conjunto de bens e serviços existentes no PNCV e no seu entorno.

Para a realização desse trabalho, o referencial teórico foi dividido em duas partes. Relativo ao estudo de caso sobre as representações de valores do PNCV para os moradores do Distrito de São Jorge e suas imediações, baseou-se em estudos que tratam do desenvolvimento rural, na linha que aborda a questão dos territórios e a multifuncionalidade das atividades no espaço rural. Esta última foi focada, em especial, no aspecto da conservação da natureza, que é o elemento marcante do objeto de estudo e proporciona o desenvolvimento da atividade turística na região. Também foram tomados como 
referência, estudos relacionados à conservação da natureza, por intermédio da implantação de UC e suas ligações com as populações residentes no seu entorno.

O referencial teórico relativo aos valores atribuídos ao PNCV e imediações por parte dos visitantes apoiou-se na questão da valoração econômica dos bens e serviços ambientais, tendo como principal elemento o Método do Custo de Viagem, para analisar a disposição a pagar dos visitantes do PARNA por um conjunto de bens e serviços ambientais aí presentes.

\subsection{CARACTERIZAÇÃO DA ÁREA DE ESTUDO}

\subsubsection{O MUNICÍPIO DE ALTO PARAÍSO DE GOIÁS E O DISTRITO DE SÃO JORGE}

O município de Alto Paraíso de Goiás, distante aproximadamente 430 km de Goiânia e 230 km de Brasília, conforme a Figura 1 a seguir. Está inserido na Microrregião da Chapada dos Veadeiros (Anexo A), que coincide com o Território da Chapada dos Veadeiros do Programa Território da Cidadania, do Ministério do Desenvolvimento Agrário (MDA), composto por 8 municípios: Alto Paraíso de Goiás, Campos Belos, Cavalcante, Colinas do Sul, Monte Alegre de Goiás, Nova Roma, São João d'Aliança e Teresina de Goiás. 


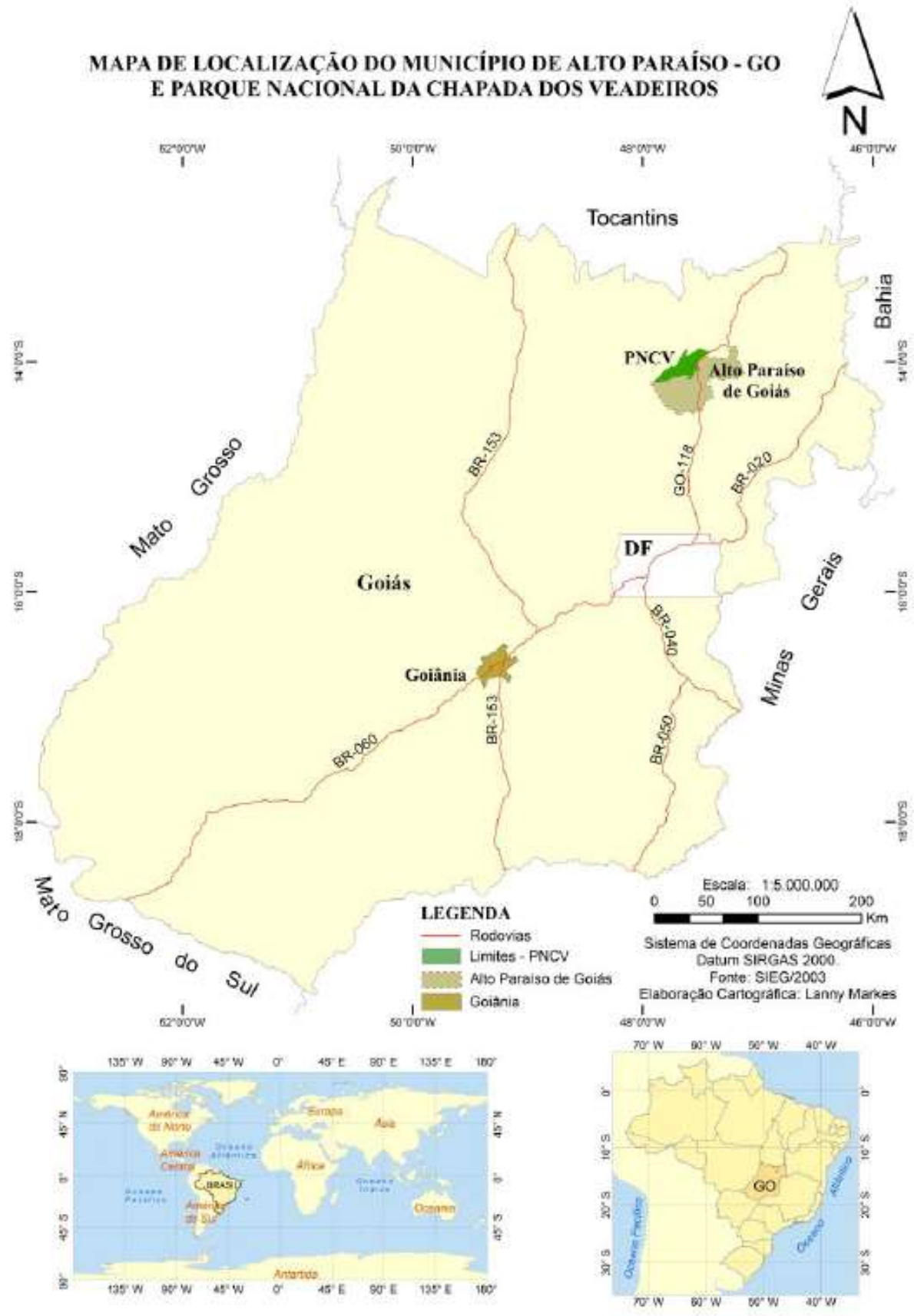

Figura1: Localização do Município de Alto Paraíso de Goiás

Fonte: SIEG/2003

O referido território apresenta uma população rural correspondente a cerca de um terço do total da sua população, que é de 62.656 habitantes, e possui um Índice de Desenvolvimento Humano (IDH) médio de 0,68, abaixo do índice médio do estado de Goiás, estipulado em 0,735 (IBGE, 2010; BRASIL, 2013). O PIB da microrregião representa 0,68\% do Produto Interno Bruto (PIB) estadual, segundo dados do Instituto Brasileiro de Geografia e Estatística - IBGE (2013). 
A microrregião tem a economia baseada na agricultura de subsistência e na pecuária extensiva, concentrando a produção nos seguintes produtos agrícolas: milho, soja, feijão, mandioca, cana-deaçúcar e arroz, destacando-se os dois primeiros. Em relação ao estado de Goiás, as culturas agrícolas mais expressivas são o milho e a soja, representando 1,25\% e 0,93\% da produção estadual, respectivamente (IBGE, 2013).

$\mathrm{Na}$ atividade pecuária, destacam-se as explorações de bovinocultura, avicultura e suinocultura. Relativamente às explorações da pecuária sobressaíram a bovinocultura com 2,83\% e a avicultura com 0,69\% da produção goiana, conforme dados do IBGE (2013) (Quadro 1).

\begin{tabular}{|l|r|r|r|}
\hline \multirow{2}{*}{} & \multicolumn{2}{|c|}{$\begin{array}{c}\text { Microrregião da Chapada dos Veadeiros } \\
\text { (CV) }\end{array}$} & Goiás (GO) \\
\hline \multicolumn{1}{|c|}{ Produto } & Quantidade & CV/GO (\%) & Quantidade \\
\hline Milho & 102.724 ton. & 1,25 & 8.230 .069 ton. \\
\hline Soja & 77.850 ton. & 0,93 & 8.398 .891 ton. \\
\hline Bovinocultura & $491.073 \mathrm{cab}$. & 2,83 & $22.045 .776 \mathrm{cab}$. \\
\hline Avicultura & $414.282 \mathrm{cab}$. & 0,69 & $59.424 .726 \mathrm{cab}$. \\
\hline
\end{tabular}

Quadro 1: Comparação da produção da microrregião da Chapada dos Veadeiros com o estado de Goiás - 2012 (Elaboração do autor)

Fonte dos dados: IBGE (2013)

Entretanto, a microrregião da Chapada dos Veadeiros concentra um grande porcentual de vegetação nativa ainda preservada no estado de Goiás, o que potencializa o seu papel para "práticas alternativas e menos impactantes no ambiente, tais como o ecoturismo e o extrativismo de frutos do Cerrado" (BRASIL, 2009, p. 36). Segundo Rocha et al. (2009), com base em dados do Laboratório de Processamento de Imagens e Geoprocessamento (LAPIG) do Insituto de Estudos Sócio-Ambientais (IESA) da UFG, alguns municípios da microrregião, que estão na área de abrangência da Zona de Amortecimento do PNCV, apresentam cobertura vegetal remanescente acima de 70\%. São eles: São João da Aliança, com 72\%; Colinas do Sul, com 80\%; Alto Paraíso de Goiás, com 84\%; Cavalcante, com 94\%; e Teresina de Goiás, com 95\%.

O município de Alto Paraíso de Goiás possui uma área de $2593,9 \mathrm{~km}^{2}$, e apresenta uma população de 6885 habitantes, divididos em 5219 habitantes constituindo a população urbana e 1666 habitantes a 
população rural, segundo o censo do IBGE (2010). O IDH do município está no patamar de 0,713 (IBGE, 2010), um pouco acima do índice da microrregião $(0,68)$ e abaixo do índice estadual $(0,735)$.

A produção agropecuária do município, segundo o IBGE (2013), nesse mesmo ano estava baseada nos principais produtos agrícolas: milho, soja, feijão, mandioca e outros de menor expressão. Na pecuária, a bovinocultura e a avicultura eram as explorações mais significativas, conforme o Quadro 2 a seguir.

\begin{tabular}{|l|r|r|r|}
\hline & \multicolumn{2}{|c|}{$\begin{array}{c}\text { Alto Paraíso de Goiás } \\
\text { (AP) }\end{array}$} & $\begin{array}{c}\text { Microrregião da Chapada dos } \\
\text { Veadeiros (CV) }\end{array}$ \\
\hline \multicolumn{1}{|c|}{ Produto } & Quantidade & $\mathrm{AP} / \mathrm{CV}(\%)$ & \multicolumn{1}{c|}{ Quantidade } \\
\hline Milho & 17.600 ton. & 17,13 & 102.724 ton. \\
\hline Soja & 12.690 ton. & 16,30 & 47.850 ton. \\
\hline Bovinocultura & $32.284 \mathrm{cab}$. & 6,57 & $414.282 \mathrm{cab}$. \\
\hline Avicultura & $16.286 \mathrm{cab}$. & 3,93 & $\mathrm{cab}$. \\
\hline
\end{tabular}

Quadro 2: Comparação da produção do Município de Alto Paraíso de Goiás com a microrregião da Chapada dos Veadeiros - 2012 (Elaboração do autor)

Fonte dos dados: IBGE (2013)

De acordo com o Censo Agropecuário de 2006, realizado pelo IBGE, havia no município 378 estabelecimentos agropecuários cadastrados e a utilização das terras se encontravam da seguinte maneira: área total com 190.439 ha; lavouras permanentes com 1.250 ha (0,66\% da área total); lavouras temporárias com 5.592 ha (2,94\% da área total); pastagens plantadas com 6.989 ha (3,67\% da área total); pastagens naturais com 77.599 ha (40,71\% da área total) e matas naturais com 89198 há (46,84\% da área total). Por esses números apresentados é possível notar a expressiva quantidade de área ocupada por pastagens naturais, que está relacionada à criação extensiva de gado, e a área reservada às matas naturais, que coincidem com as unidades de conservação que abrangem as terras do município, principalmente a Área de Proteção Ambiental (APA) do Pouso Alto e o PNCV.

De acordo com o IBGE, no ano de 2011, a atividade agropecuária no município contribuiu com 23,87\% para a formação de seu PIB, sendo que as atividades relacionadas ao setor de serviços, que abarca o turismo, representaram $61,67 \%$ do PIB municipal.

O Distrito de São Jorge dista 36 km a oeste da cidade de Alto Paraíso de Goiás, seguindo a estrada GO239, que faz a ligação com a cidade de Colinas do Sul, inicialmente com $22 \mathrm{~km}$ asfaltados e mais $14 \mathrm{~km}$ 
a serem percorridos em estrada de terra, onde se encontra a sede administrativa e o portão de entrada do PNCV.

Os registros paroquiais do Distrito indicam que o mesmo foi criado em 1912, formado por um acampamento de garimpeiros, chamado de Garimpão, que deu origem a um povoado, conhecido por Baixa dos Veadeiros (BRASIL, 2009). Foi renomeado para Vila de São Jorge na década de 1950 e elevado à categoria de Distrito de São Jorge em 1996 (Prefeitura Municipal de Alto Paraíso de Goiás, 1998).

Segundo a Secretaria de Turismo de Alto Paraíso de Goiás, a população atual do Distrito de São Jorge é de aproximadamente 500 habitantes, cuja maioria se dedica à atividade turística desenvolvida na UC. De acordo com a Administração Local, o Distrito possui cerca de 28 pousadas, 15 áreas de camping para alojamento dos turistas que se destinam ao PNCV e atrativos do seu entorno.

\subsection{2 - O PARQUE NACIONAL DA CHAPADA DOS VEADEIROS}

O Parque Nacional da Chapada dos Veadeiros foi criado sob o nome de Parque Nacional do Tocantins, em 1961, e conta atualmente com cerca de 65.514 ha de área. Seus limites se estendem entre as coordenadas geográficas de $13^{\circ} 53^{\prime}$ a $14^{\circ} 11^{\prime}$ de latitude sul, e de $47^{\circ} 25^{\prime}$ a $47^{\circ} 54^{\prime}$ de longitude oeste (Figura 2), compreendendo um perímetro de cerca de $160 \mathrm{~km}$, com altitudes variando entre 400 e 1676 m. As partes leste e sul confrontam-se com terras do município de Alto Paraíso de Goiás e as divisas oeste e norte são delimitadas por domínios do município de Cavalcante. Dois outros municípios, Colinas do Sul e Teresina de Goiás, têm parcelas de seus municípios pertencentes à Zona de Amortecimento do PNCV. 


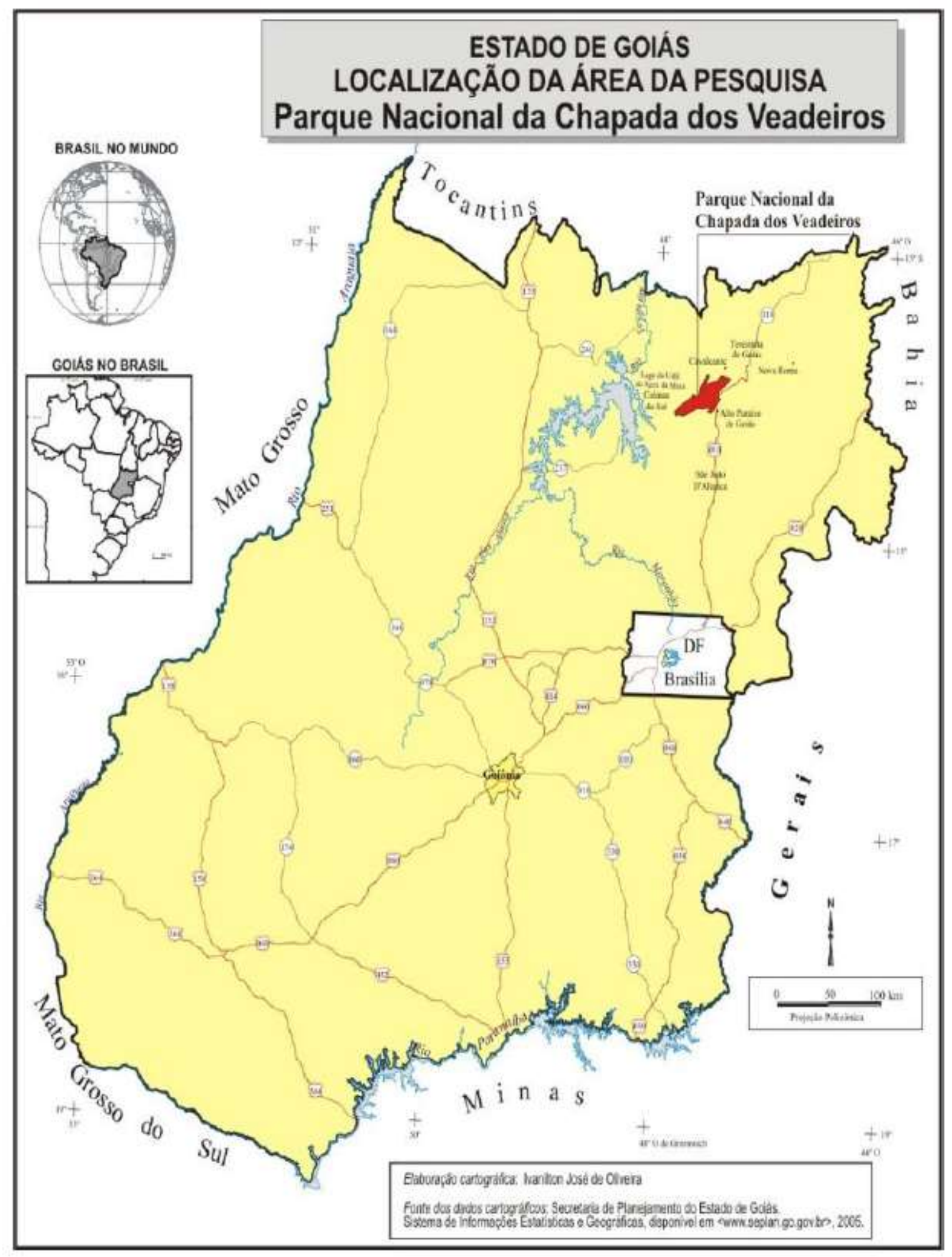

Figura 2: Mapa de Goiás - Localização do PNCV

Fonte: Oliveira (2007) 
A área do PNCV se assenta em sua maior extensão sobre o Complexo Montanhoso Araí-Nova RomaVeadeiros, situando-se na parte noroeste da região do nordeste goiano e apresenta as maiores altitudes do estado (MARTINS, 2011). Segundo Oliveira (2007, p. 47), a região da Chapada dos Veadeiros caracteriza-se pela antiguidade de suas rochas, com "estruturas geológicas ligadas a movimentos antigos como dobramentos, falhamentos e fraturas". Ainda, conforme o autor, esses falhamentos podem apresentar "intrusões de espessos veios de quartzo", fenômeno que originou a atividade garimpeira na região.

O Rio Preto, afluente do Rio Tocantins é o principal curso d'água que corta de leste para oeste o Parque Nacional, recebendo as águas de córregos que descem de suas encostas, formando pequenos vales transversais. Percorrendo as fraturas rochosas que são características do local, forma cânions e corredeiras, e os desníveis aí encontrados dão origem às cachoeiras e saltos.

A fitofisionomia da região é variada, sendo que as mais representativas são as "formações savânicas estacionais campestres (campo rupestre, campo limpo e campo sujo) e porções de cerrado de sentido restrito (denso, rupestre e ralo). Ocorre a presença de formações florestais ladeadas por campos úmidos substituídos por áreas alagadas, com a presença de buritis (palmeiral de vereda)" (BRASIL, 2009, p. 12).

No interior do Parque Nacional existem condições favoráveis para a manutenção de uma grande diversidade da flora e da fauna regionais, que inclui espécies raras e ameaçadas de extinção. No caso da flora, citam-se algumas espécies, bem características da região: chuveirinho (Paepalanthus scandens), candombá (Vellozia sp.), canela-de-ema (Vellozia squamata), palipalã (Paepalanthus elongatus) e algumas espécies ameaçadas pela exploração desmedida, como a arnica (Lyncochnophora enicoides) e a aroeira (Myracondron urundeuva). Em relação aos animais, destacamse espécies de mamíferos como o lobo-guará (Chrysocium brachyurus) e a onça pintada (Panthera onça); espécies de aves como o pato-mergulhão (Mergus octocetaceus), a codorna (Nothura minor) e o socó-boi-escuro (Coryphaspiza melanotis); no grupo dos anfíbios são registrados espécimes endêmicos do cerrado, entre eles o sapo-de-chifre (Proceratophrys goyana) e o sapo-fusquinha (Odontophrynus salvatori), entre outras espécies animais (BRASIL, 2009).

Dentre esses exemplos, um caso específico, que torna a área de estudo como relevante é o fato de que o PNCV constitui-se em um dos poucos locais de procriação do pato-mergulhão (Mergus octosetaceus), "uma espécie criticamente ameaçada que ocorria no Brasil, Argentina e Paraguai. 
Atualmente, existem registros apenas no Brasil e na Argentina. (...) A estimativa populacional atual é de apenas cerca de 250 aves na natureza e nenhuma em cativeiro" (HUGHES, 2006, p.15). O mesmo autor cita que, no Brasil, a ave ocorria em oito estados do centro sul do país - Bahia, Goiás, Minas Gerais, Tocantins, São Paulo, Rio de Janeiro e talvez Paraná e Santa Catarina, com evidências de já ter sido extinta em estados como São Paulo, Rio de Janeiro e Santa Catarina, mantendo-se em pequenos números em localidades disjuntas de Goiás (no PNCV e entorno), Minas Gerais e Tocantins.

Por esse motivo, uma das trilhas que conduz ao Cânion I, um dos atrativos do Parque, está interditada, proibida à entrada de visitantes, em atendimento ao que dispõe o Plano de Manejo do PNCV, conforme destacam Domiciano e Oliveira (2012).

A área de visitação do Parque é composta por duas trilhas (Figura 3). A primeira, com aproximadamente 5 km, conduz ao Cânion II e à Cachoeira das Cariocas. O Cânion II constitui-se de um grande desfiladeiro, com um paredão de pedra com cerca de $20 \mathrm{~m}$ de altura, onde o Rio Preto se afunila, e na sua parte mais baixa, forma poços que podem ser utilizados para banhos, verdadeiras piscinas naturais. Na Cachoeira das Cariocas, em um ponto mais abaixo do mesmo rio, após uma íngreme descida, avistam-se várias quedas d'água, em cujos poços é permitida a entrada dos visitantes.

A segunda trilha, com um percurso médio de 4,5 km, passa pelos Saltos II ( $120 \mathrm{~m}$ de altura) e I ( $80 \mathrm{~m}$ de altura) e depois, pelas corredeiras do Rio Preto. A chegada ao pé do Salto Il é proibida, por motivo de segurança, porém o mesmo pode ser contemplado de um mirante, numa parte da trilha, que permite também a visualização dos vales recortados pelo Rio Preto. No poço do Salto I é permitida a entrada para banho, com uma grande área para usufruto dos visitantes, até certa distância da queda d'água. Subindo a trilha, um pouco mais adiante, chega-se às corredeiras, onde o rio apresenta pequenas quedas e passa por entre fendas de rochas, propiciando banhos de "hidromassagem". A capacidade de lotação das trilhas, definida pela administração do Parque, é de 200 pessoas/dia para a primeira trilha e 250 pessoas/dia para a segunda trilha. 


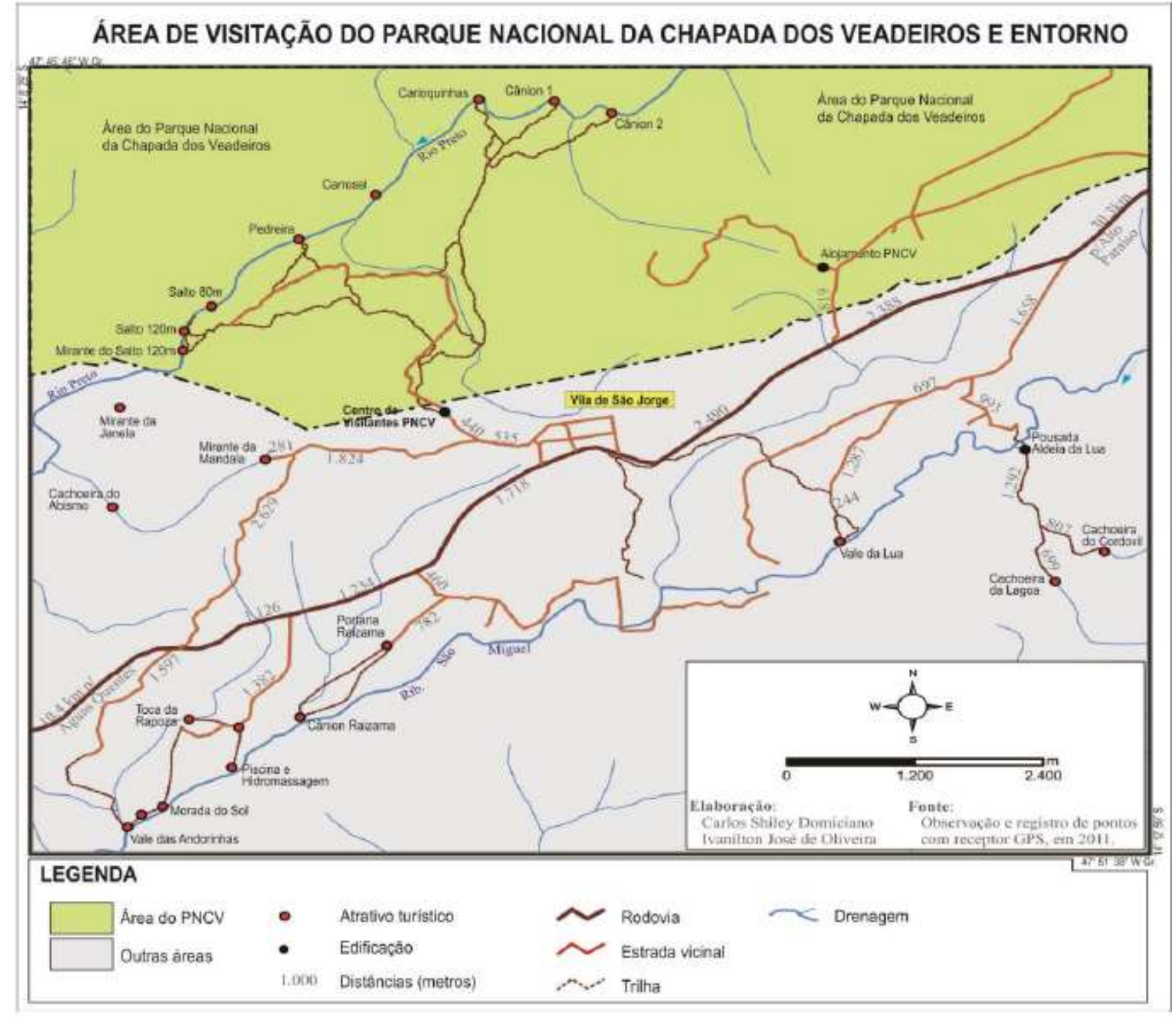

Figura 3: Mapa de localização das trilhas no PNCV e atrativos próximos.

Assim, o PNCV inclui entre seus atributos, que lhe conferem certo valor de uso, não somente o conjunto de bens e serviços que constituem os seus atrativos naturais e que são passíveis de serem mensurados em termos monetários pelo $\mathrm{MCV}$, como apresenta uma estreita relação com o valor de existência de espécies raras ou ameaçadas de extinção, o que lhe concerne vital importância no tocante à sua conservação e manutenção.

O Parque ainda guarda em seu interior as marcas da atividade que faz parte da história da região da Chapada dos Veadeiros, intimamente ligada à sua origem. São as catas deixadas pela garimpagem forma quase que exclusiva de sobrevivência das pessoas da localidade - e que atualmente são vestígios de uma época. 
A trilha para os Saltos do rio Preto (tradicionalmente conhecidos como Saltos do Garimpão) passa por trechos do antigo garimpo onde até hoje se encontram resquícios das atividades extrativas minerais do início do século $\mathrm{XX}$, proporcionando uma rica abordagem histórico-cultural que agrega grande valor ao desenvolvimento de práticas turísticas e educativas. Este local constitui um sítio histórico na área do PNCV (BRASIL, 2009, p.23).

Além desses elementos que constituem o conjunto de bens e serviços que ele pode proporcionar aos seus visitantes, o PNCV também apresenta um forte vínculo com o seu entorno, principalmente as imediações do Distrito de São Jorge, por onde passa o Ribeirão São Miguel, na sua Zona de Amortecimento. No mesmo existem cerca de 30 atrativos, em propriedades particulares, entre cachoeiras e corredeiras, que variam de 3 a 150 m de altura, dentre elas se destacam o Vale da Lua, o Raizama, a Morada do Sol, o Segredo, entre outros.

Todos esses atrativos se agregam ao conjunto de belezas naturais que induzem os turistas a se deslocarem para a região, para usufruírem de suas amenidades, uma vez que a maioria dos visitantes que se destinam ao PNCV também visitam esses locais.

\subsection{FOTOGRAFIAS DO PNCV, ATRATIVOS DO ENTORNO E DO DISTRITO DE SÃO JORGE FEITAS PELO}

\section{AUTOR EM JULHO DE 2012}

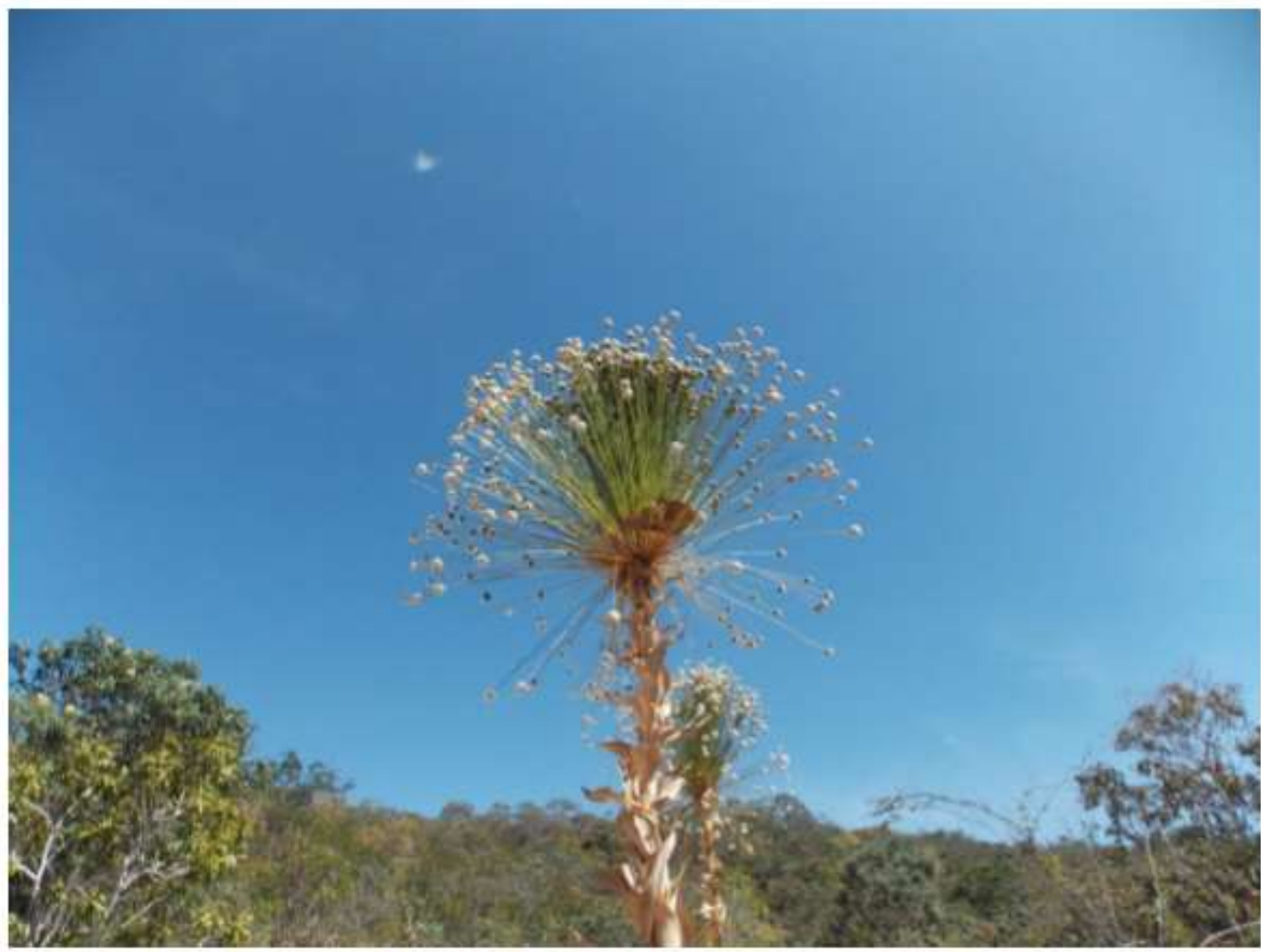

Figura 4: Chuveirinho 


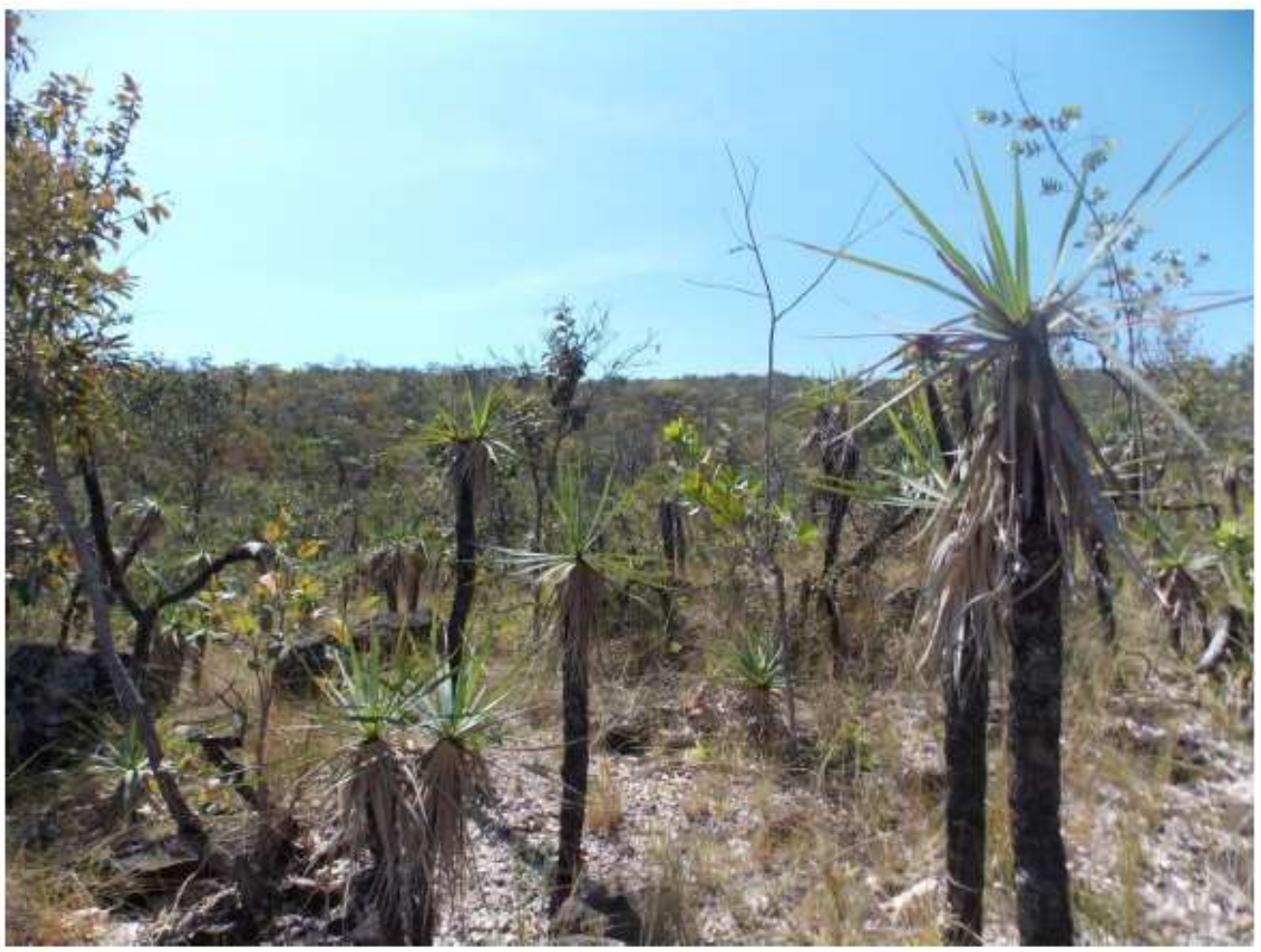

Figura 5: Candombá

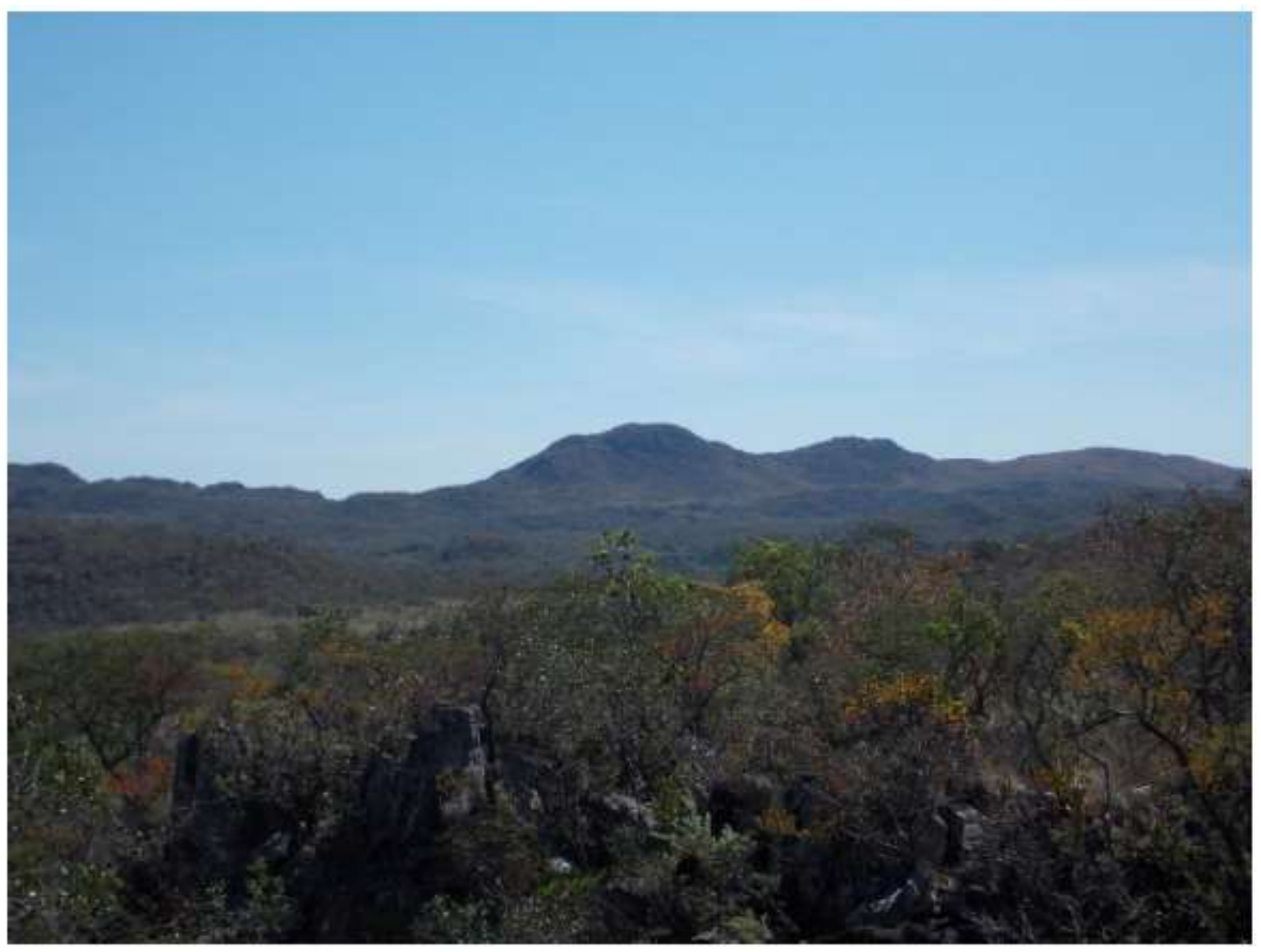

Figura 6: Vista panorâmica do PNCV (Trilha do Cânion) 


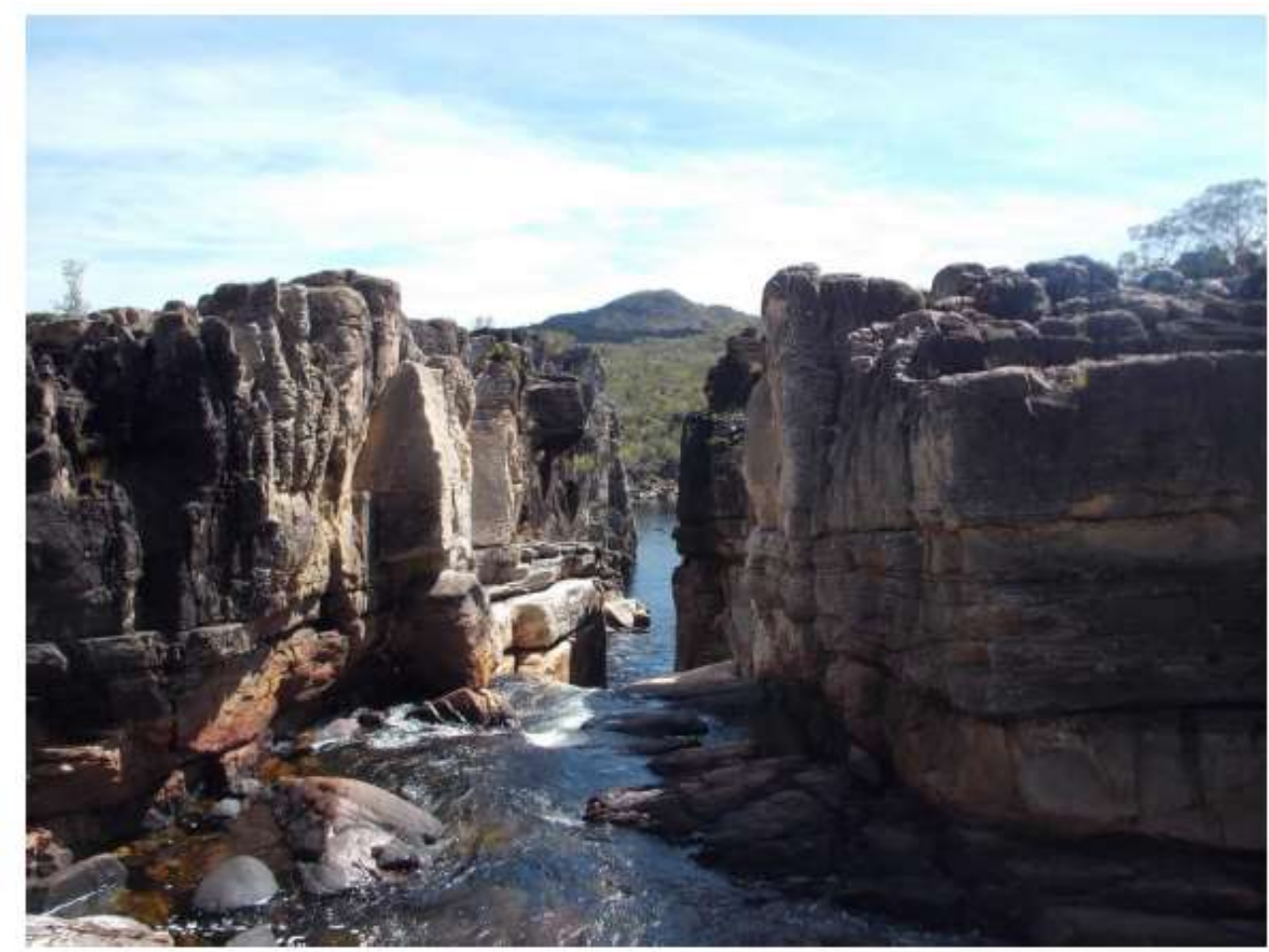

Figura 7: Cânion 2

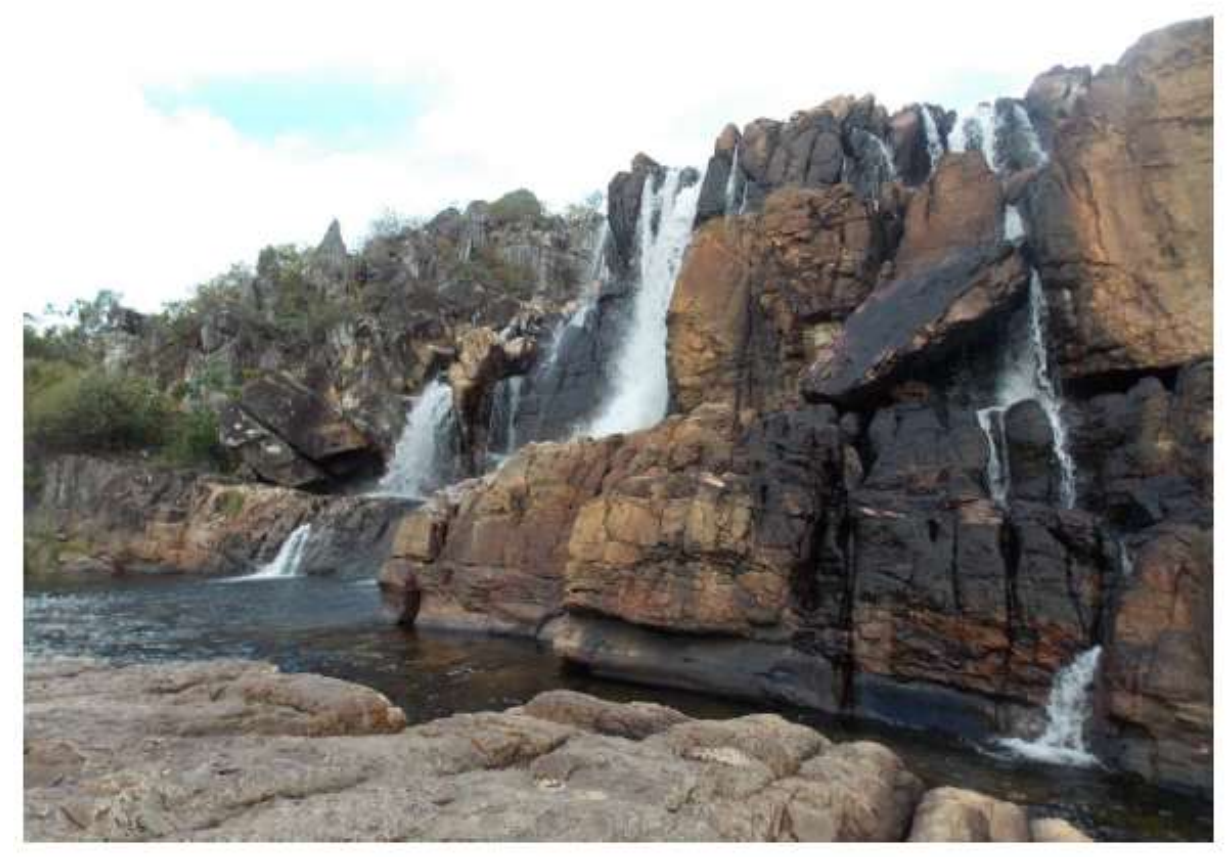

Figura 8: Cachoeira das Cariocas 


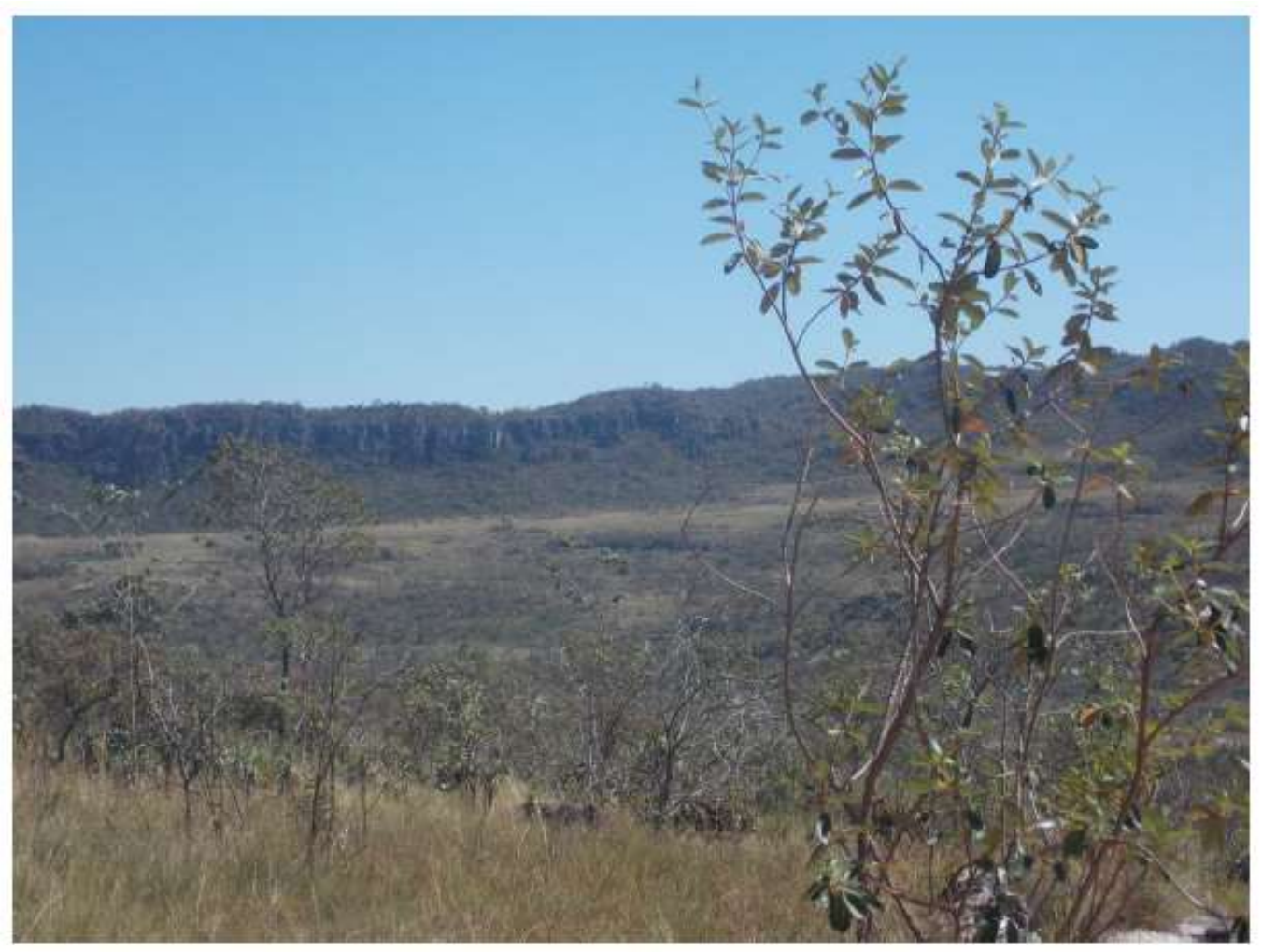

Figura 9: Vista panorâmica do PNCV (Trilha dos Saltos)

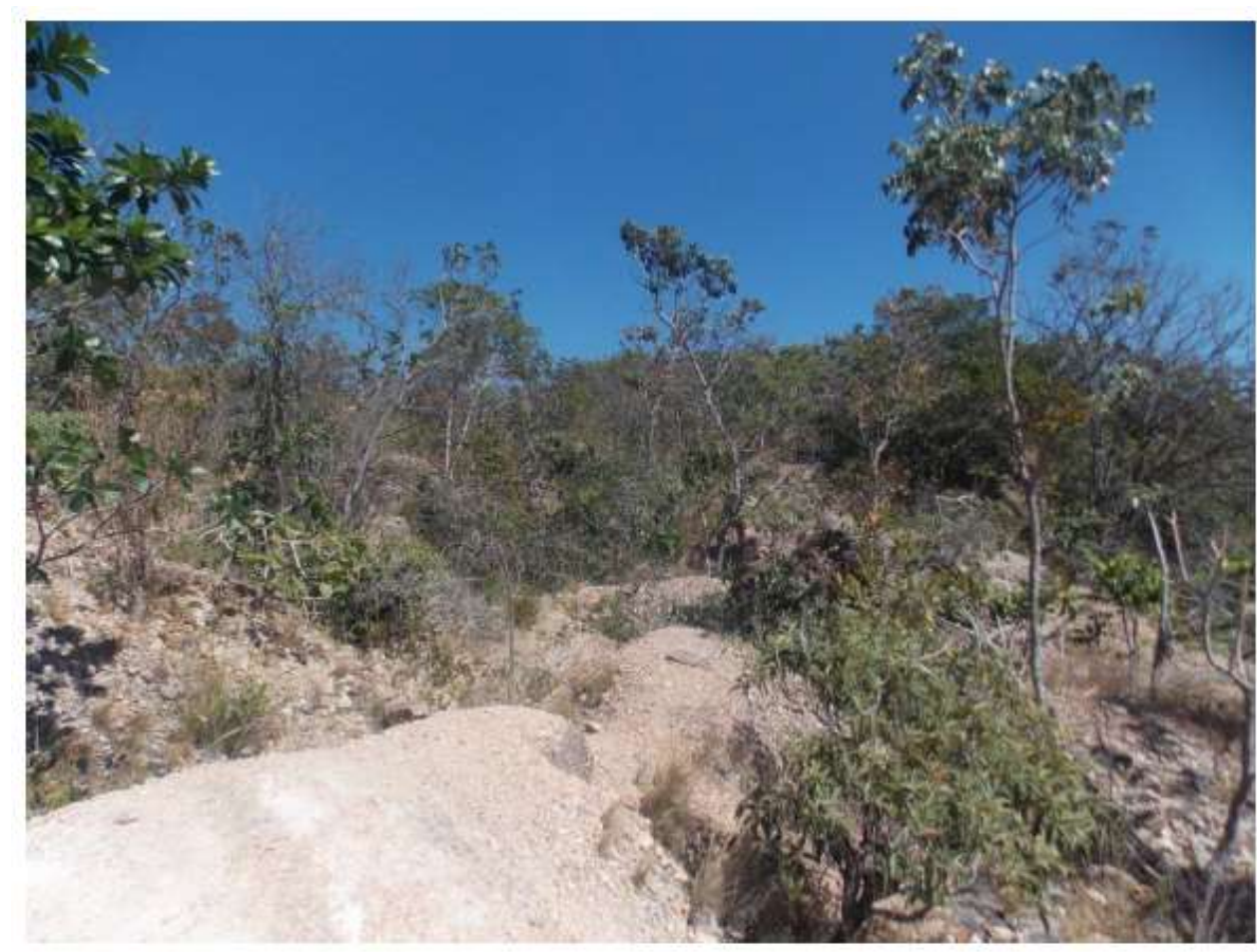

Figura 10: Catas do garimpo no PNCV 


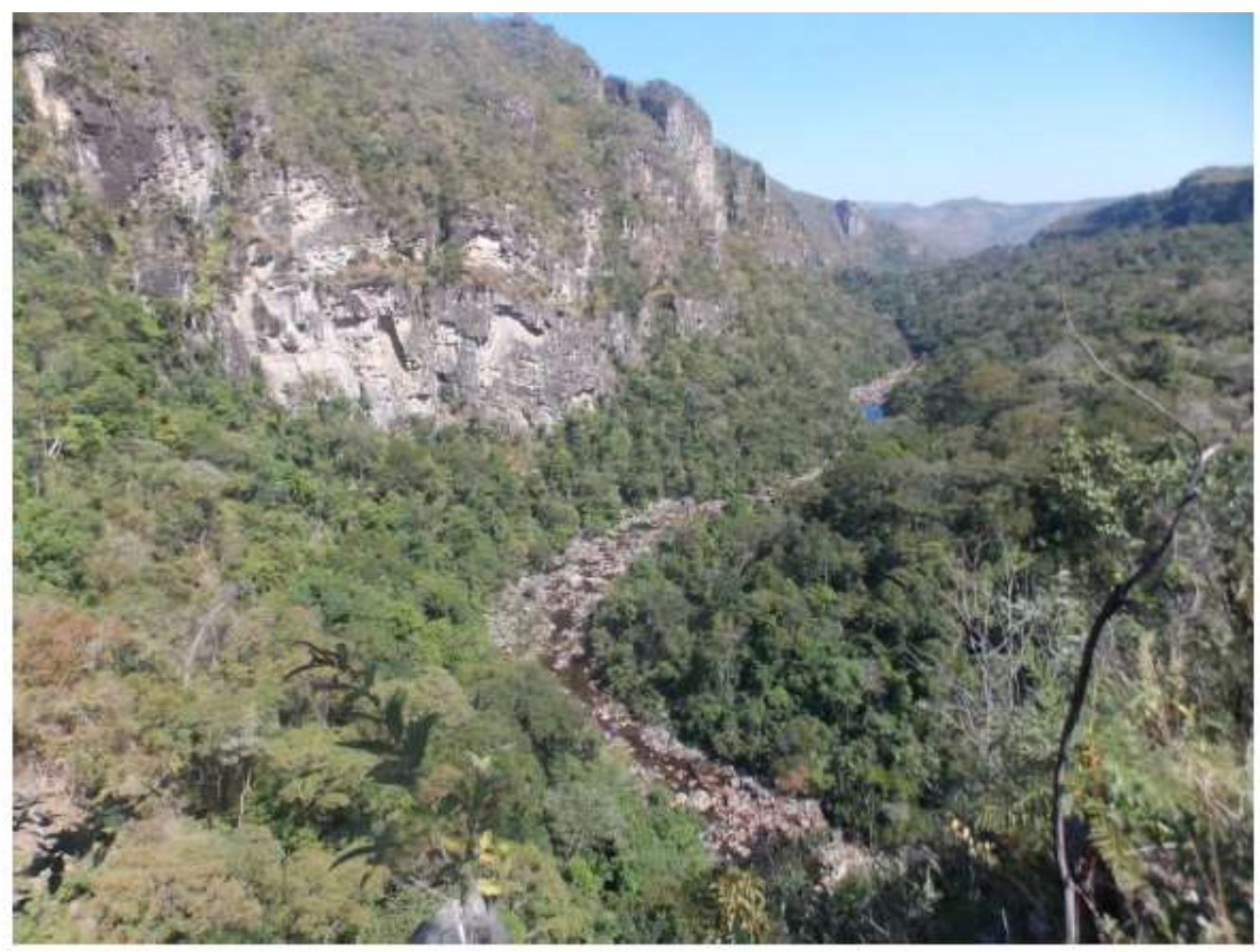

Figura 11: Vista panorâmica do vale do Rio Preto

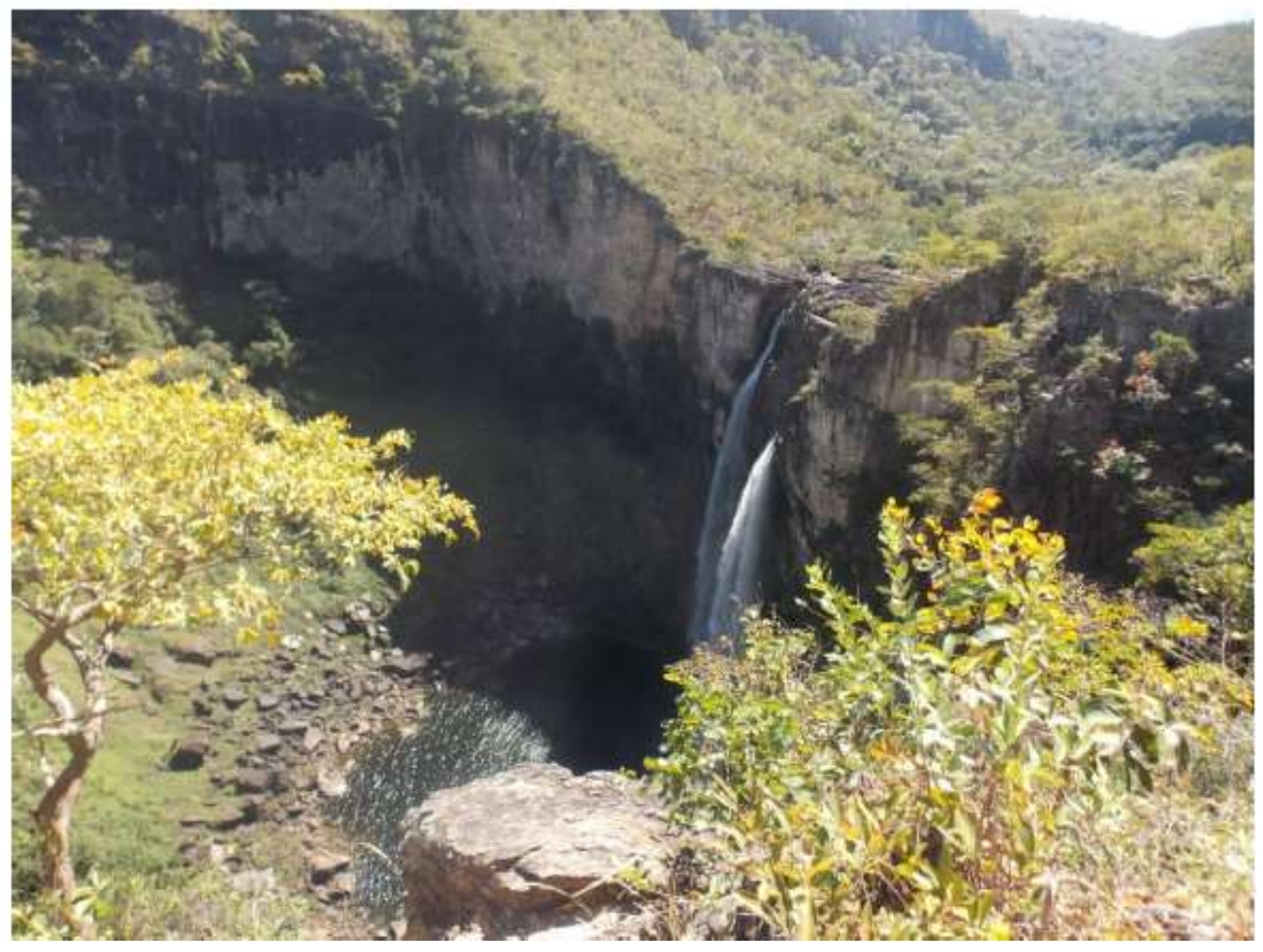

Figura 12: Vista do Salto de $120 \mathrm{~m}$ 


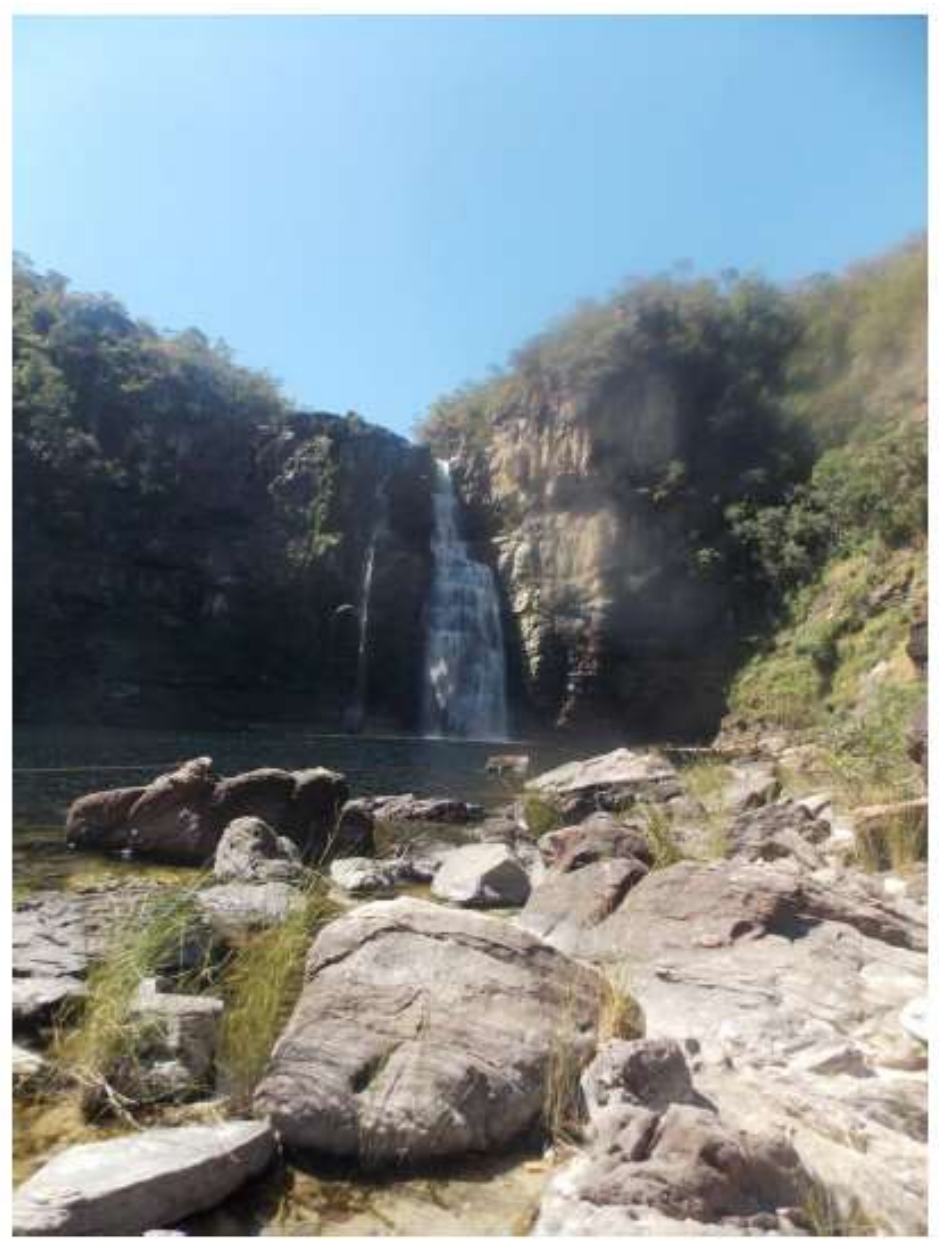

Figura 13: Vista do Salto de $80 \mathrm{~m}$

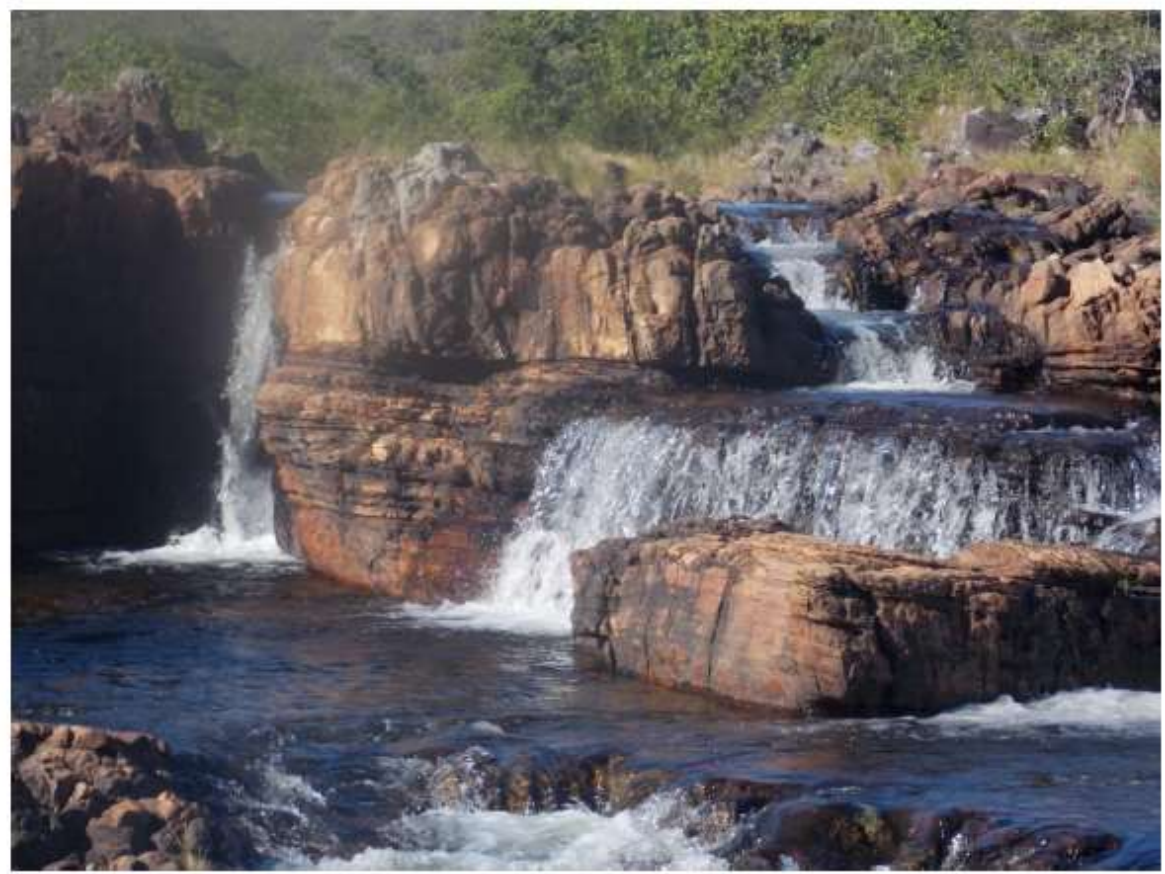

Figura 14: Corredeiras 


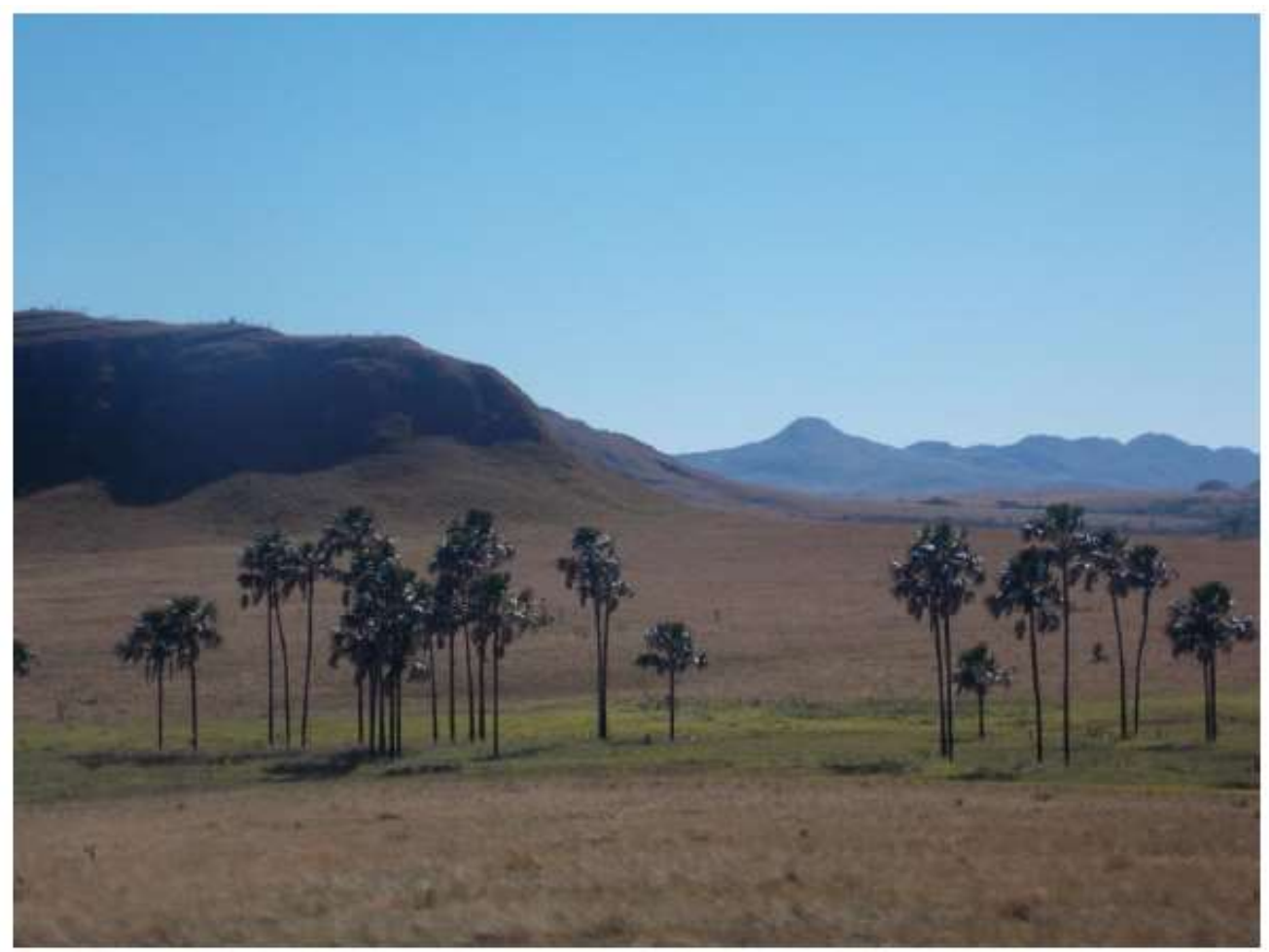

Figura 15: Jardim de Maitreya

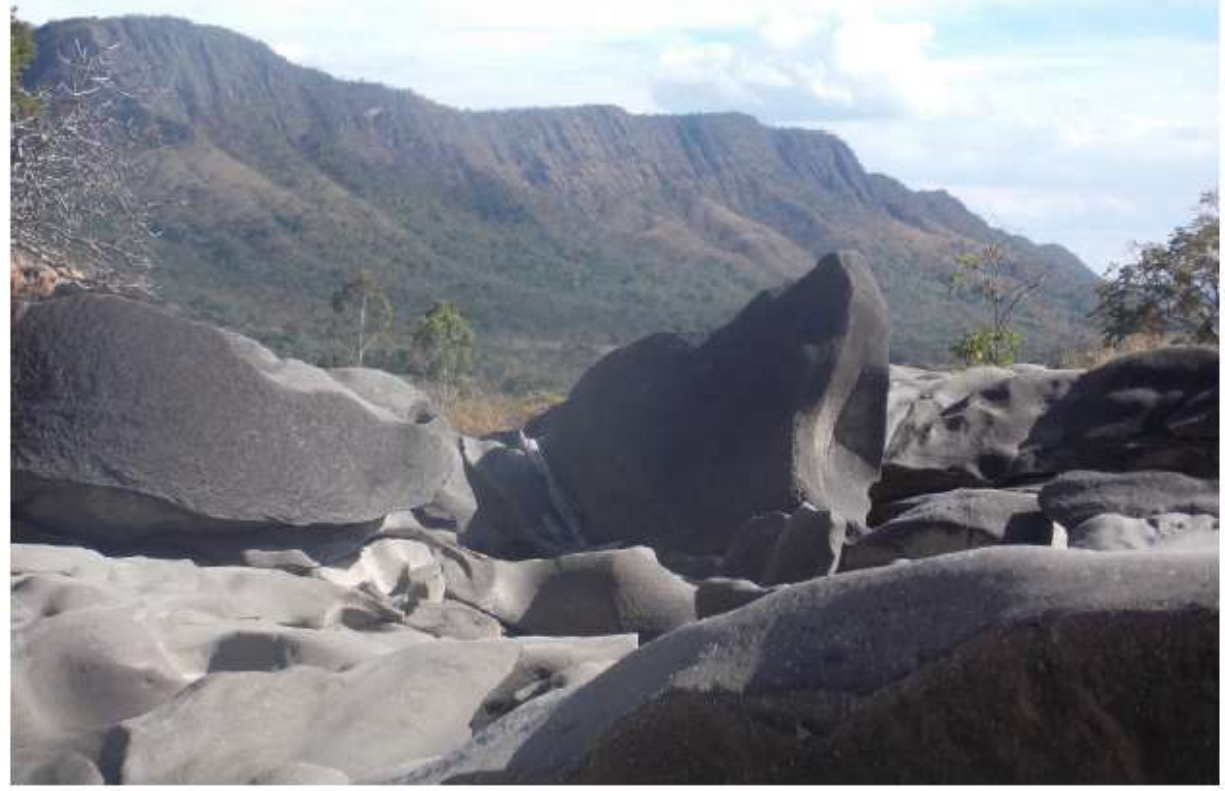

Figura 16: Vale da Lua (entorno do PNCV) 


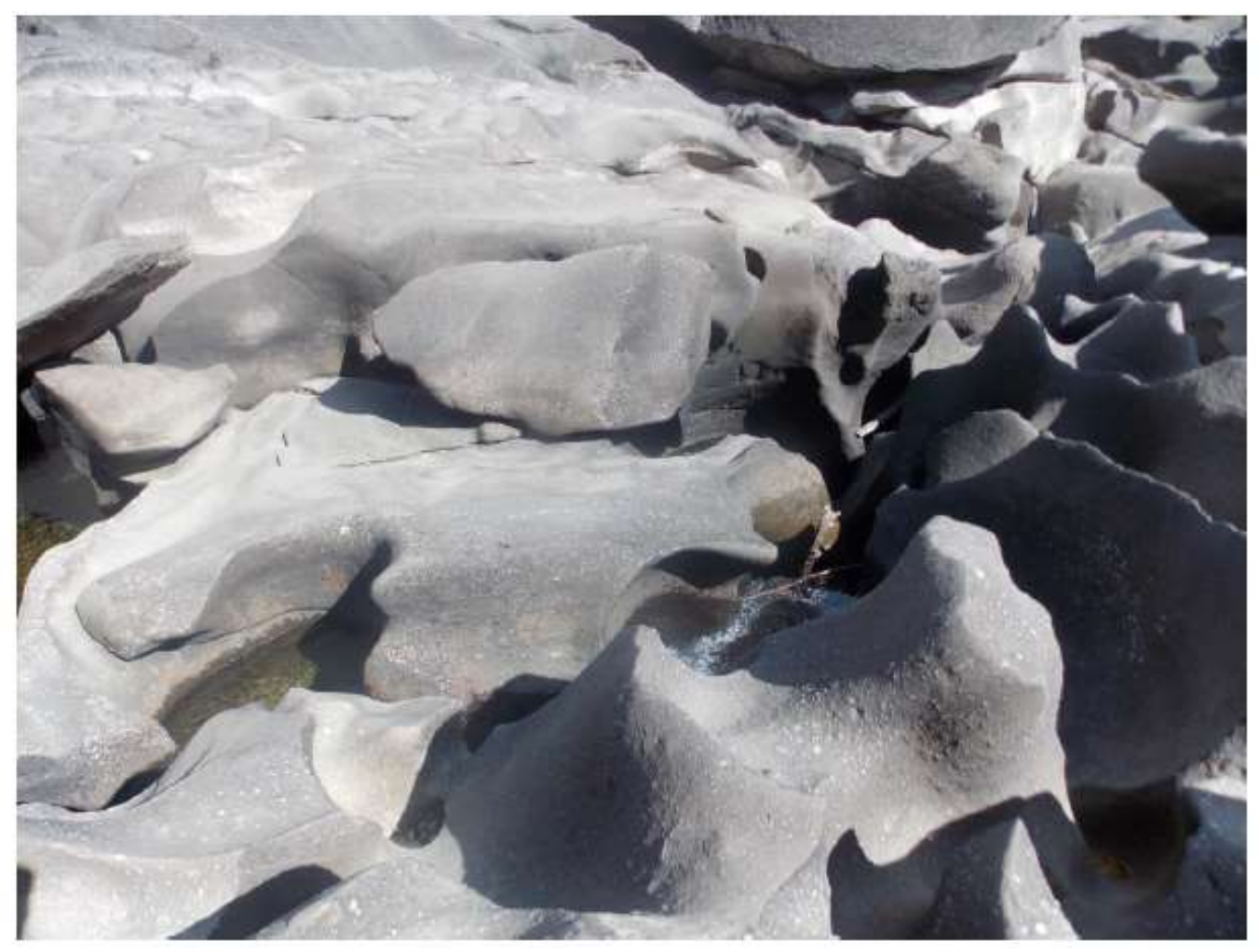

Figura 17: Vale da Lua (entorno do PNCV)

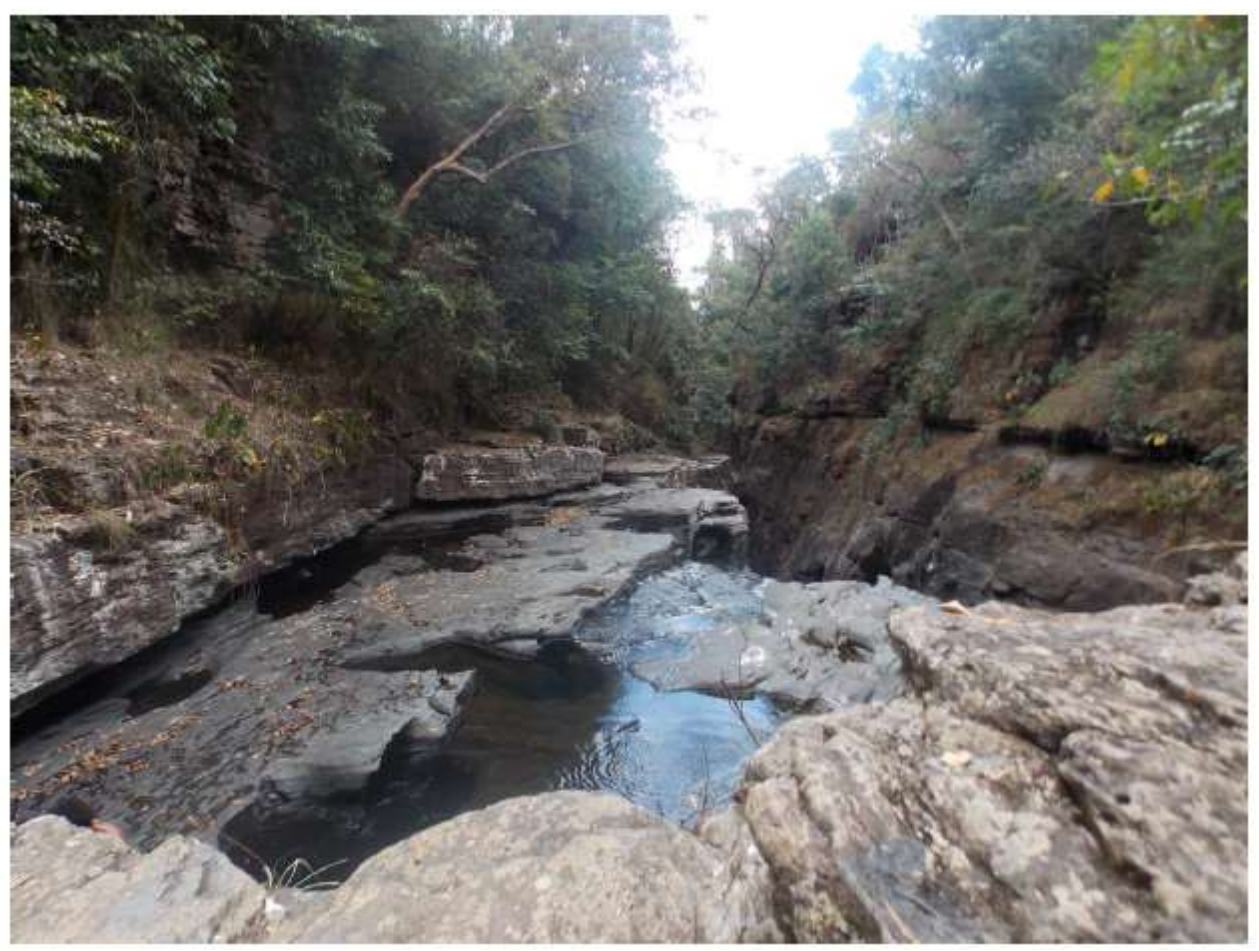

Figura 18: Raizama (entorno do PNCV) 


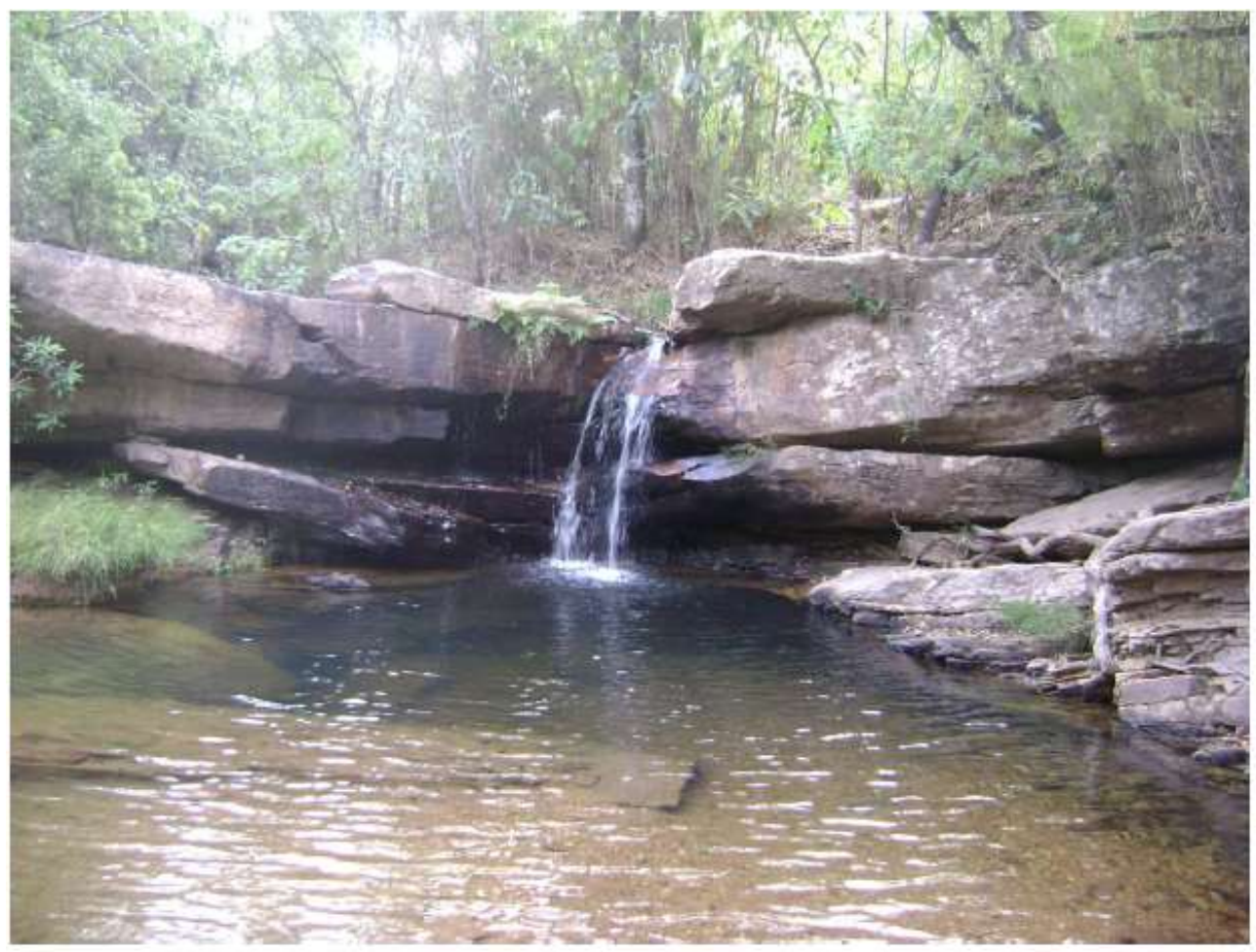

Figura 19: Raizama (entorno do PNCV)

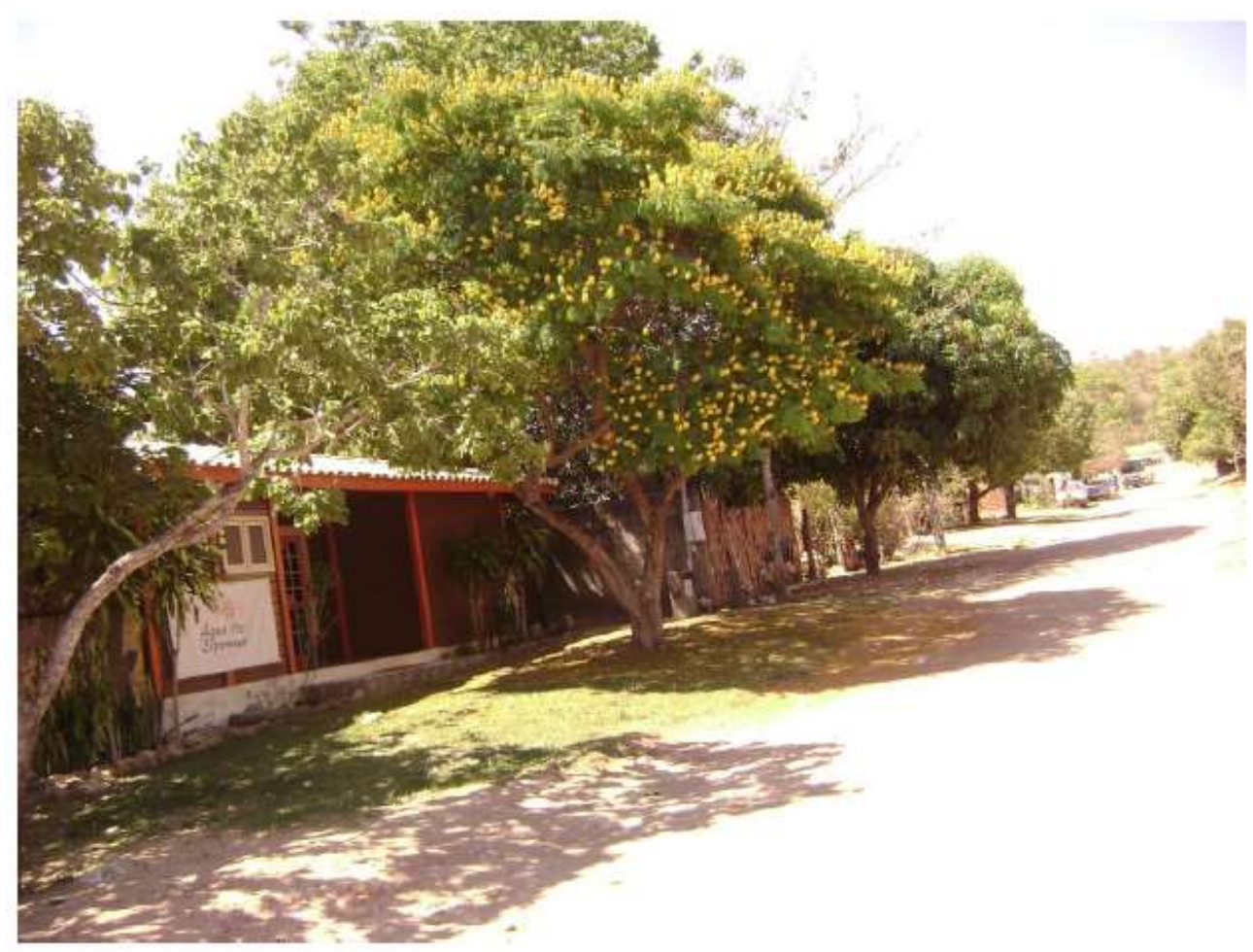

Figura 20: Vista parcial do Distrito de São Jorge 


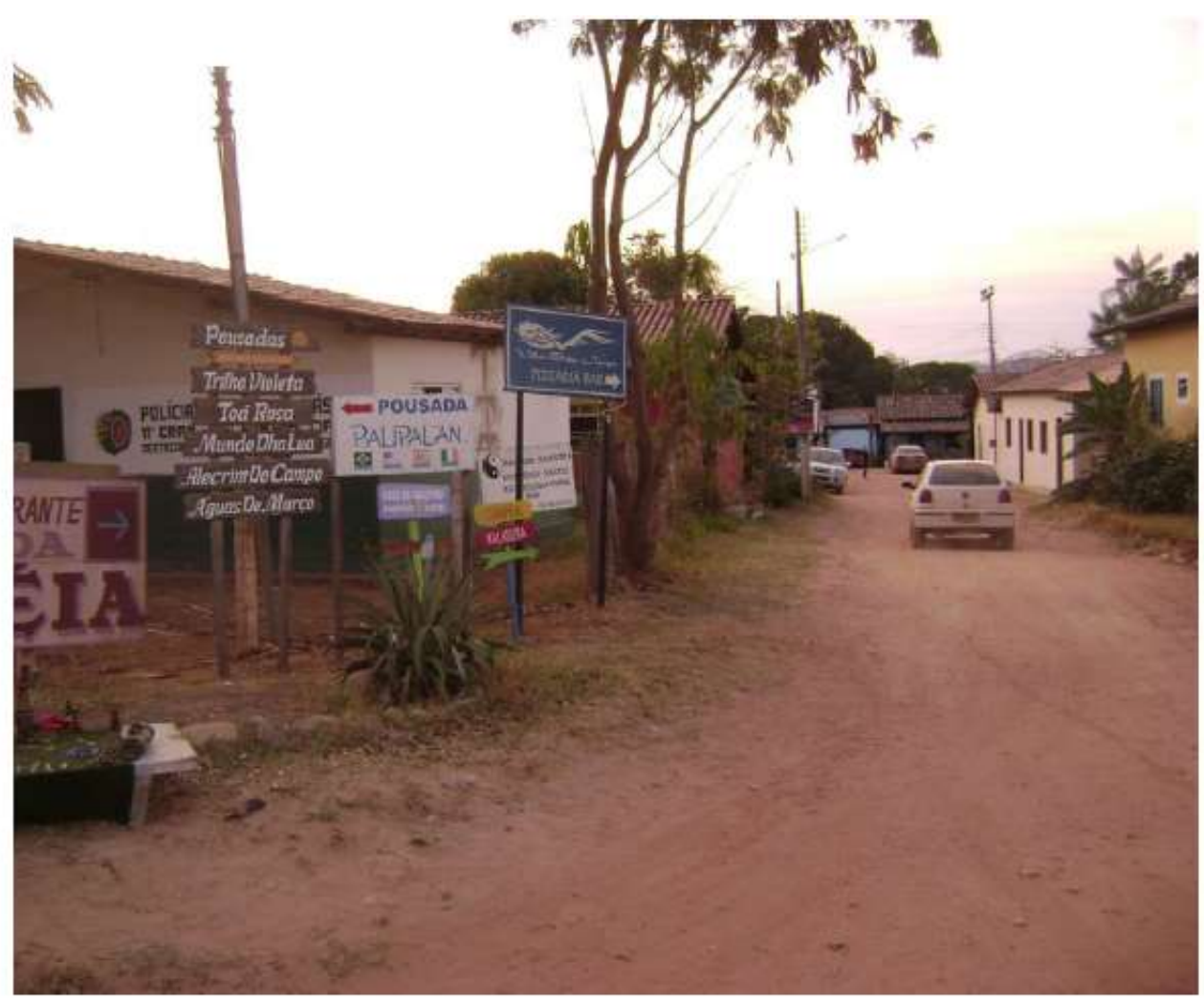

Figura 21: Vista parcial do Distrito de São Jorge

\section{DESENVOLVIMENTO RURAL E A CONSERVAÇÃO AMBIENTAL}

\subsection{NOVOS VALORES PARA O RURAL}

As áreas rurais antes isoladas, nas últimas décadas do século passado, passaram a ser o foco das atenções em virtude das funções que podiam desempenhar, e as pessoas que aí habitavam precisaram buscar novas formas de atingir um patamar de desenvolvimento, refletindo as preocupações com a conservação ambiental.

Com as mudanças que ocorreram nas comunidades rurais, novos elementos culturais, sociais e econômicos foram incorporados ao dia a dia das pessoas, criando novas relações e identidades, modificando o seu fazer cotidiano. O espaço passou a ser não mais identificado somente como agrícola, mas também enquanto elemento de novas alternativas, como a (re)valorização da natureza, conforme destaca Carneiro (2012), quando propõe uma linha de estudos sobre as ruralidades contemporâneas, ao buscar uma maior compreensão a respeito dos modos de viver e pensar o rural no Brasil.

Uma tendência de olhar o rural para além do agrícola apontou para novas dinâmicas sociais das localidades que, por sua vez, se transformaram num palco de confluência de diversos atores sociais. 
Essa dinâmica introduz novas dimensões de "localidade" e de "comunidade". Pensada como uma construção social e não como um espaço reificado, a localidade estaria em contínua reformulação a partir de novas relações engendradas pelos diferentes atores sociais, que passam a ter como referência, seja para o trabalho, seja para a moradia, um mesmo território (CARNEIRO, 2012, p. 38).

Nesse território, a partir do momento em que o aspecto produtivo da agricultura deixa de ser uma atividade principal, estabelecem-se as bases para o surgimento da multifuncionalidade (CARNEIRO, 2009), e de novas oportunidades em termos de atividades econômicas. Além do aspecto social, de manutenção das pessoas nas zonas rurais, a função ambiental se sobressai nesse espaço, e gera um conflito de interesses, como aponta Carneiro (2012, p. 47), "as noções de rural como espaço de preservação ambiental e de natureza como meio de contemplação passam a ser concorrentes da terra como meio de produção agrícola". Mesmo aqueles espaços destinados à conservação da biodiversidade tornam-se palco de disputas, refletindo uma situação dúbia, mencionada por Seabra (1998) em que o mesmo sistema produtivo que leva o poder público a criar as áreas de conservação, também pressiona tais áreas em busca de recursos para o seu funcionamento.

É o que aconteceu com o cerrado brasileiro, mesmo em processo de ocupação e exploração tardios iniciados com a Marcha para o Oeste nos anos de $1940^{2}$, e atualmente em função do atendimento às demandas do processo de produção de commodities, trazendo consequências sociais e ambientais. “A ocupação dos cerrados, ocorrida nas duas últimas décadas, transformou consideravelmente o perfil da região e a relação entre as populações ali adaptadas e meio ambiente, além de acelerar a diminuição da biodiversidade" (DUARTE, 2002, p. 17).

Outro aspecto a se considerar, é de que nas áreas de proteção ambiental, em virtude da restrição de seu uso, "as estratégias prevalecentes de conservação acabam sendo geradoras de pobreza" (NOVAES, LOBO e FERREIRA, 2008, p. 132). Irving, Rodrigues e Novaes Filho (2002, p. 108) reafirmam essa ideia e destacam que, "ironicamente, algumas áreas caracterizadas por pobreza rural detêm um elevado patrimônio natural, expresso por sua biodiversidade e/ou recursos hídricos em áreas protegidas".

As pessoas dessas localidades, por sua vez, acabam por enfrentar as dificuldades com a criação de uma unidade de conservação, ao se analisar a sua mudança de comportamento frente aos objetivos que uma UC preconiza, ou por determinações instituídas pela força da lei.

Contudo, a criação de uma UC numa determinada região, além das suas funções primordiais que lhe são atribuídas pelo SNUC no que tange à conservação dos ecossistemas, permite que sejam realizadas algumas atividades relacionadas à educação ambiental, de recreação e lazer e turismo ecológico, não 
só no seu interior, como também nas suas adjacências, principalmente nas suas regiões confrontantes, nas denominadas Zonas de Amortecimento, que também requerem atenção especial no que diz respeito à questão ambiental (BRASIL, 2000).

Assim, nessas áreas rurais, a agricultura tem a sua função produtiva restringida em favor da preservação do meio ambiente e da paisagem, e o turismo, mais precisamente o ecoturismo ganha seu espaço, porque não dizer ocupa o espaço, marcando bem a abordagem da multifuncionalidade das atividades, conferindo renda às pessoas aí residentes, em garantia de sua sobrevivência.

Coriolano (2002, p. 52), enfatiza que o ecoturismo torna-se uma possibilidade de desenvolvimento, sendo uma atividade de baixo impacto ambiental, que pode propiciar sustentação econômica às regiões onde se implementa: "é uma alternativa para as economias locais que desenvolvem a agricultura familiar, o extrativismo, a pesca artesanal e outras atividades ligadas à Natureza".

A autora ainda complementa, referindo-se a essa modalidade turística como uma estratégia de desenvolvimento sustentável: “O ecoturismo é uma forma de valorizar o patrimônio natural, histórico e cultural e de participar do viver das comunidades locais. É o turismo motivado pela valorização ambiental e pela descoberta da natureza como valor estético transformado em ativo ambiental" (CORIOLANO, 2002, p. 52).

Esse turismo pode constituir-se em um elemento que venha trazer benefícios não só para os turistas, ao entrar em contato com a natureza, valorizando-a por intermédio do lazer e da recreação, mas também uma estratégia de "conciliação", segundo Bensusan (2006), entre conservação e o uso da biodiversidade, para o desenvolvimento das comunidades adjacentes e das áreas de proteção ambiental.

Nesse aspecto, essas áreas rurais por natureza, veem a sua função de produção se deslocar para uma função de conservação ambiental que lhes confere uma nova valorização.

\subsection{AS UNIDADES DE CONSERVAÇÃO E AS RURALIDADES CONTEMPORÂNEAS}

A ideia de rural que emergiu nos anos de 1970, a partir das transformações nas economias capitalistas e da crise do setor agrícola no Brasil, deu início a novas formas de conceber e gerir o espaço rural. 0 campo já não é somente responsável pela produção de alimentos a preços mais acessíveis, novas expectativas e desejos surgiram e outras funções agregaram-se ao fazer rural. A todo instante, está mais difícil identificar o que seja rural ou urbano, a época em que cada espaço tinha uma função prédefinida esvaiu-se (PIRES, 2004). 
Atividades desempenhadas em outros setores da economia começaram a se desenvolver fora das cidades, dentre elas cita-se o turismo praticado no espaço rural, complementando e tornando-se a principal referência econômica de determinadas localidades. Com esse enfoque é necessário ajustar as políticas voltadas para o meio rural e dirigí-las também para toda a população rural, e não somente aos agricultores, pois a diversidade de atividades e o "esgotamento do modelo produtivista fez com que a pauta das políticas públicas para o rural fosse ampliada, incluindo entre essas atividades nãoagrícolas, assim como a dimensão ambiental" (PIRES, 2004, p.156). O mesmo autor também destaca que a separação rural-urbano prevaleceu até o momento em que "os processos de urbanização e industrialização funcionavam de modo 'clássico', isto é, enquanto os centros urbanos concentravam os principais recursos (mão-de-obra, comunicações, serviços, entre outros) e mercados" (PIRES, 2004, p.159).

Outra forma utilizada para balizar o que seria rural e urbano referia-se à população, considerando-se o seu tamanho e sua densidade. Kageyama (2008, p. 37) discorda desse ponto de vista e acrescenta mais alguns elementos para análise:

Além de extremamente simplificadoras da realidade, não há consenso sobre os limites dessas variáveis que separariam rural e urbano, mesmo em situações que admitam uma gradação entre os extremos. Os problemas ocorrem porque as áreas rurais não se distinguem das urbanas apenas por aspectos demográficos, mas também por elementos econômicos, sociais e culturais.

Graziano da Silva (2002a, p.61) reforça esse pensamento, ao afirmar que ainda que existam diferenças entre as pessoas que moram nas áreas urbanas e rurais, nos quesitos de renda e acesso a determinados bens e serviços (saneamento, educação, saúde, infraestrutura, recreativos), “a idéia de dois mundos que se opõem vai cedendo lugar à idéia de um continuum espacial, seja do ponto de vista de sua dimensão geográfica e territorial, seja na dimensão econômica e social”.

O desenvolvimento da economia produziu mudanças em todas as áreas da sociedade, tanto na questão produtiva, quanto na de consumo; a agricultura, que antes podia ser considerada como um setor com certa autonomia produtiva integrou-se ao restante da economia, já não podendo mais ser vista separadamente dos setores que lhe fornecem insumos e/ou compram seus produtos (GRAZIANO DA SILVA, 2002a).

Van der Ploeg (2009), em estudo que trata da recampenização do agricultor europeu, aponta como a agricultura pode e deve continuar dando suporte ao desenvolvimento de uma localidade reconstituindo, na atualidade, suas bases naturais e sociais de produção. Como alternativa ao modo de produção agrícola vigente, voltado exclusivamente para o mercado, os agricultores começaram a 
diversificar suas atividades, em que novos produtos e serviços são produzidos para novos mercados. Destacam-se também ações de cooperação local, a pluriatividade, a reintrodução da artesanalidade (combinando os trabalhos intelectual e manual das pessoas) e, a "reconexão da agricultura com a natureza tem desempenhado um papel central" (VAN DER PLOEG, 2009, p. 47) nesse processo.

A percepção de que as áreas rurais também são áreas de consumo adquire uma conotação importante, mesmo que esse consumo provenha de uma determinada demanda de pessoas oriundas das cidades, que tenham migrado para o meio rural, passando a valorizá-lo e a lhe atribuir qualidades positivas tais como moradia, recreação, lazer e proteção ambiental (PIRES, 2004).

Seabra (2012) indica os interesses dos viajantes para as localidades rurais, ao ressaltar que, além da busca pela interação com as atividades agropecuárias, também procuram o contato com o patrimônio cultural e com os elementos naturais aí presentes

Os visitantes optam por conhecerem as atividades rurais desenvolvidas nas pequenas, médias e grandes propriedades, associadas a diferentes modalidades de lazeres e recreação. Também podem vivenciar os hábitos e conhecer os sistemas produtivos simples das comunidades rurais tradicionais em contato íntimo com a natureza (SEABRA, 2012, p. 31).

Abramovay (2000) em deferência aos estudos de dois institutos franceses (Instituto Nacional de Estatísticas e Estudos Econômicos - Insee / Instituto Nacional de Pesquisa Agronômica - Inra) em que se confrontam "espaço produtor" e "espaço consumido" no meio rural, aponta que é cada vez menos legítimo o uso exclusivo dos espaços rurais para a produção agroindustrial. Também reforça que as estratégias de desenvolvimento rural devam considerar temas de natureza ambiental, pois "à medida que a noção de ruralidade incorpora o meio natural como um valor a ser preservado [...] vão ganhando forças as políticas e as práticas produtivas voltadas para a exploração sustentável da biodiversidade" (ABRAMOVAY, 2000, p.9).

No aspecto de que o meio rural torna-se um "espaço consumido", e que o mesmo passa a ser procurado pelas pessoas dos centros urbanos para entrar em contato com o meio natural, estas passam a ser "consumidoras da natureza" e das atividades daí advindas (KAGEYAMA, 2008). Dessa forma "o mundo rural vem sendo valorizado cada vez mais como produtor de 'bens não tangíveis' tais como a paisagem e o lazer ao lado dos tradicionais produtos agropecuários (...) além de um espaço de preservação ambiental" (GRAZIANO DA SILVA, 2002 a, p.120), orientando-se para atividades ligadas à prestação de serviços. 
A procura por localidades nas zonas rurais para moradia, para desfrute de suas amenidades ou ainda para atividades recreativas, vai ao encontro do primeiro quesito que Abramovay (2000) indicou como sendo característico da ruralidade, a relação com a natureza, implicando em um contato mais imediato dos moradores locais com o meio natural do que os das cidades. Essa "relação com a natureza emerge não só como um valor ético ou afetivo" (ABRAMOVAY, 2000, p.7), como também pode ser uma fonte de renda para as localidades, no caso de uma exploração turística.

O rural está sendo associado, cada vez mais, a um espaço de lazer, de residência, de investimento e de distração. Seguindo essa perspectiva, surgem novas modalidades de turismo (ecoturismo e turismo rural, por exemplo) que fomentam o crescimento do setor de serviços no campo, engendrando novas relações sociais e de trabalho no espaço rural (RODRIGUES, 2012, p. 229).

Dessa forma, o turismo pode se transformar em uma estratégia alternativa de desenvolvimento para as comunidades locais, como afirma Rozo (2002, p. 132) e

não deixa de ser um fenômeno particularmente interessante, dadas as possibilidades de contribuir para o crescimento regional harmônico com a natureza, de pequenas comunidades, que em geral estão assentadas em territórios com alta riqueza paisagística e cultural nos países em vias de desenvolvimento.

Outro quesito citado por Abramovay (2000), é a relativa dispersão populacional em contraposição com as aglomerações e congestionamento populacional das grandes cidades, que levam a uma situação de estresse da vida metropolitana. Essa dispersão pode favorecer as relações de proximidade familiar, de vizinhança e comunitárias nas localidades rurais.

O terceiro e último quesito tem a ver com a relação com as cidades, pois as regiões rurais não podem "escamotear sua completa dependência com relação às cidades" em termos de bem-estar econômico, pois é fundamental a integração orgânica entre cidade e campo, "sem eliminar as particularidades da organização social, econômica, e territorial das áreas não densamente povoadas" (ABRAMOVAY, 2000, p.13-14).

Por sua vez Chalita (2005), mostra o modo rural de viver e suas várias formas:

A noção de "ruralidade" como "modo de vida constitutivo de um determinado ambiente" [...] indica fenômenos de usos múltiplos do espaço geográfico, pluriatividade, demanda por educação e qualidade de vida, acesso a técnicas, circuitos de produção e inserção cultural no mundo urbano e redes de sociabilidade diversas que envolvem os agentes econômicos da produção agrícola (CHALITA, 2005, p. 98).

Schneider et al. (2009, p.140) ressaltam que a pluriatividade explicita o processo de diversificação do trabalho no meio rural e demonstra "a transição da própria função da agricultura, que além de 
produzir alimentos e gerar emprego, favorecendo o processo de acumulação de capital, se apresenta hoje como um setor multifuncional, que não deve ser analisado apenas pela sua eficiência produtiva, mas também pela sua contribuição à preservação ambiental e à própria dinamização do espaço rural". Wanderley (2012) se refere ao rural como um objeto multifacetário com sua diversidade de dinâmicas e atores sociais e revela as suas várias dimensões, além da produtiva, com as atividades agrícolas e não agrícolas; a residencial, que reivindica a extensão dos serviços urbanos às comunidades rurais e a "dimensão patrimonial que enfatiza a paisagem rural como uma riqueza pertencente a todos, estimulando atividades econômicas no campo do lazer e do turismo" (WANDERLEY, 2012, p.17).

Assim, segundo Graziano da Silva (2002a), já não é possível identificar o mundo rural somente pelas atividades agropecuárias, o mesmo passa a desenvolver outras formas de organização socioeconômica comuns a outros setores da sociedade, que demandariam novas modalidades de regulação do Estado, entre as quais, políticas na área ambiental, de bem-estar social, de desenvolvimento rural, etc.

O mesmo autor ressalta que, por esses fatos, torna-se necessário reconceituar o agrário, ou como frisou Pires (2004, p. 163), repensar o rural, que "já não estaria mais associado a um espaço geográfico determinado. Tido como um constructo social, múltiplo e aberto, não há como falar de um único rural, mas de ruralidades construídas que se relacionam com diferentes espaços geográficos".

Seguindo por essa linha de pensamento, Brandão $(2007$, p.33) assegura que:

\footnotetext{
Nenhum recorte espacial é natural [...] as escalas são construções históricas, econômicas, culturais, políticas e sociais e, desse modo, devem ser vistas na formulação de políticas. É preciso repactuar relações, reconstruir espaços públicos e canais institucionalizados de concertação de interesses e estabelecer contratos sociais territorializados.
}

Santos (1997) enfatiza que os elementos do espaço são os homens, as instituições, a infraestrutura, o suporte ecológico. Da relação entre os elementos de um lugar, ditada pelas suas condições, surge a sua valorização, "cada lugar atribui a cada elemento constituinte do espaço um valor particular" (SANTOS, 1997, p.10), que não se baseia em si próprio, mas em um contexto maior onde se encontra difuso.

O entendimento de que a reconstrução do rural se baseia numa abordagem multissetorial, que envolve vários atores, além dos agricultores, que se relacionam entre si, exigindo uma análise das instituições em torno das quais se organizam uma interação social (ABRAMOVAY, 2007), remete à noção de que essa ruralidade tenha um caráter de natureza territorial e não setorial (ABRAMOVAY, 2000). Segundo o mesmo autor, a ideia central é que 
O território, mais que uma base física para relações entre indivíduos e empresas, possui um tecido social, uma organização complexa feita por laços que vão além de seus atributos naturais [...] representa uma trama de relações com raízes históricas, configurações políticas e identidades (ABRAMOVAY, 2000 , p.6, grifo do autor).

De acordo com Pires (2004, p. 169), muitos autores, ao abordarem o tema território, ressaltam o seu conteúdo político administrativo, indicando certo domínio individual ou coletivo sobre uma determinada parte da sociedade. Para este autor, a noção de território vai além de uma base material, tem a ver com as interações entre as pessoas que habitam uma mesma localidade, com valores que aproximam ou afastam essas pessoas, é "algo construído historicamente permeado por relações políticas, econômicas e culturais" que define limites (físicos ou simbólicos) e "demarcam o pertencimento a uma formação socioespacial", constituindo um processo que dá origem a espécies de identidades sociais.

Diegues e Nogara (1999) mostram a importância do território na relação entre as sociedades tradicionais e a natureza, ao destacar que nesta "porção do mundo natural", é onde se encontram os meios de subsistência, de trabalho e produção, e os aspectos materiais das relações sociais, e frisa que “o território depende não somente do tipo de meio-físico explotado, mas também das relações sociais existentes" (DIEGUES e NOGARA, 1999, p. 36).

Brandão (2009) diz que um território, por vincular-se a um determinado grupo social, onde se observa um jogo de poder, expressa as interações de seus atores. Partindo desse princípio, o autor frisa que o território apresenta como características marcantes o fato de ser

\footnotetext{
uma construção social, por natureza conflituosa. Uma produção coletiva, dinâmica, multidimencional, com trajetória histórica em aberto. [...] O território é uma unidade privilegiada de reprodução social, denominador comum, desembocadura, encarnação de processos diversos e manifestação de conflitualidades (BRANDÃO, 2009, p. 54).
}

Para Leff (2009, p. 362), o território se converteu no espaço de lutas e resistência de várias comunidades latino-americanas, desde os processos de colonização até os dias atuais, com a globalização da economia, em que se observa uma forma de reapropriação da natureza. Essas comunidades, por meio de seus movimentos sociais " $r$-existiram reinventando-se a partir de sua própria cultura". O autor destaca exemplos no Brasil, quando comunidades tradicionais da Amazônia, como seringueiros, "se territorializam reinventando suas práticas como Reservas Extrativistas, estão valorizando todo o contexto ecológico-sócio-cultural que habitam” (LEFF, 2009, p. 363). 
Nesse sentido, Brandão (2007, p. 54), reitera que, com as crises surgidas na sociedade a partir da exploração do sistema de produção dominante, "diversos grupos de pressão regionais procuram vocalizar suas demandas, e o regionalismo nada mais é que a expressão política desses grupos, que buscam construir sua identidade no recorte territorial, mobilizando-se para o enfretamento com outras unidades e escalas espaciais no Estado".

Carneiro (2012) refere-se ao território como uma representação que se mantém por intermédio de uma rede de relações sociais, sendo que uma localidade pode ser permeada por diversos territórios, de acordo com os vários interesses de seus membros e suas identidades territoriais. Essa teia de relações que se estabelece em uma localidade, ainda que crie tensões e conflitos, pode levar a um enriquecimento do tecido social local, com as trocas que ocorrem entre os vários atores envolvidos, criando um "processo de reestruturação dos sistemas sociais a partir da incorporação de novos elementos econômicos, culturais e sociais" (CARNEIRO, 2012, p. 48).

A questão da territorialidade, segundo Luchiari (2002, p. 116) entra no campo relacional do poder, com suas representações e na produção dos valores que um determinado grupo mantém entre seus membros e com o ambiente em que se encontram, "pois, ao traçarem territorialidades, os homens conjugam as relações com a Natureza e com as próprias relações sociais de poder". Paulillo (2000, p. 23) complementa esse raciocínio ao apontar essa dinâmica de poder em um território, tendo em vista que o mesmo "é o resultado de uma construção social e política no qual os agentes individuais e coletivos trocam recursos de poder e articulam interesses", e que "as relações de poder podem apresentar uma conformação territorial".

Acerca do relacionamento dos vários tipos de poder no território, Mior (2005, p. 36) acrescenta que não deve existir "uma exclusividade de um poder em relação a um território baseada na característica que territórios são entidades que se justapõem, mas não se superpõem". Em se tratando do poder público, por exemplo, em nível municipal, além do poder do governo local, têm-se os poderes dos governos estadual e federal. "Neste sentido ocorrem superposições de territórios com forma variada e limites não coincidentes, podendo existir atritos e contradições entre os respectivos poderes" (MIOR, 2005, p. 37).

Uma dimensão socioambiental que Abramovay (2007) considera no estudo de regiões rurais, quando na abordagem territorial, é o destaque na forma de como um grupo social explora seus recursos para a sua produção, tornando-se importante a sua relação com o meio onde está inserido - "relação entre sistemas sociais e ecológicos". Nesse ponto de vista, os territórios se transformam "nos resultados da 
maneira como as sociedades se organizam para usar os sistemas naturais em que se apóia sua reprodução" (ABRAMOVAY, 2007, p.21), seja ela econômica ou social. Leff (2009, p. 361) afirma que esse relacionamento com o meio faz surgir novos atores na construção de uma dinâmica ambiental, "gerando uma ressignificação da natureza e, assim, a emergência de novos protagonistas que com ela teceram suas vidas e culturas: indígenas, afrodescendentes, camponeses, ribeirinhos, pescadores".

Abramovay (1999) aponta que o sucesso das regiões rurais dos países desenvolvidos, conforme estudo da Organização para a Cooperação e Desenvolvimento Econômico (OCDE), resulta de uma dinâmica territorial específica, que estimula a formulação de políticas e projetos que valorizam atributos locais e regionais no processo de desenvolvimento.

A noção de território abre caminho para um avanço notável no estudo do próprio, já que convida a que coloque ênfase na maneira como os diferentes atores - privados, públicos e associativos - relacionam-se no plano local. 0 processo de desenvolvimento é o resultado da forma específica como são usados os fatores materiais e imateriais disponíveis, com base nessas relações (ABRAMOVAY, 2007, p. 27).

Por sua vez, a noção de território impede a confusão entre crescimento econômico e processo de desenvolvimento (ABRAMOVAY, 2007). Veiga (2010) esclarece que o processo de desenvolvimento estende-se para além do simples aumento da riqueza ou crescimento econômico de uma região. A esse processo é necessário se acrescentar a expansão das liberdades humanas propostas por Amartya Sen - Prêmio Nobel de Economia de 1998, dando ênfase que

A busca de bem-estar, de democracia e de paz precisa ser combinada, em última instância, com a necessidade de conservação de suas próprias bases materiais, isto é, a conservação dos ecossistemas por mais artificializados que alguns necessariamente se tornem (VEIGA, 2010, p. 38).

Kageyama (2008, p. 52) corrobora esse entendimento quando se trata do desenvolvimento rural, que deve ser "visto como um processo que envolve múltiplas dimensões: dimensão econômica, dimensão sócio cultural, dimensão política-institucional e dimensão ambiental”. Ademais, a autora acrescenta que ao processo de desenvolvimento de uma região, é necessário incorporar explicitamente os indicadores de bem-estar das pessoas, na forma de desenvolvimento humano (medido pelo IDH, proposto pelas Nações Unidas) e de sustentabilidade ambiental, identificado com o desenvolvimento sustentável.

Por desenvolvimento sustentável entende-se que "é aquele que atende as necessidades do presente sem comprometer a possibilidade de as gerações futuras atenderem suas próprias necessidades" (CMMAD, 1991, p.46). 
Veiga (2008) afirma que a noção de desenvolvimento sustentável liga as temáticas do crescimento econômico à ambiental e se refere à questão da sustentabilidade ambiental. O autor salienta que o uso da expressão "desenvolvimento sustentável" indica uma "tomada de consciência sobre a problemática dos limites naturais", começando a prevalecer a ideia de que o desenvolvimento não deve ser atingido simplesmente, "deve ser qualificado: ser ecologicamente sustentável" (VEIGA, 2008, p. 192).

Para Leff (2009, p. 204), o desenvolvimento sustentável deve também expressar os aspectos culturais e ecológicos de uma comunidade e levar em consideração "as necessidades de revalorização de suas práticas tradicionais de uso dos recursos [...] visto que passa pela socialização da natureza e o manejo comunitário dos recursos baseados em princípios de diversidade ecológica e cultural".

Essa concepção de desenvolvimento se origina na ideia do ecodesenvolvimento proposta por Sachs (1986), em que se analisa a utilização dos recursos de uma localidade, visando não só a satisfação das necessidades atuais das pessoas como também as futuras e alia elementos culturais com os ambientais. Esse processo deve ser um "estilo de desenvolvimento particularmente adaptado às regiões rurais" das áreas mais pobres do planeta, cujo "esforço se concentra na valorização de seus recursos específicos, para a satisfação das necessidades fundamentais da população" (SACHS, 1986, p.15).

Segundo Chalita (2005), ao se acrescentar a variável ambiental ao desenvolvimento rural, cria-se o desenvolvimento rural sustentável, um campo muito maior do que variáveis unidimensionais que definem sustentabilidades políticas, institucionais ou econômicas. Guanzirolli (2006) afirma que ao se somar as características da territorialidade com os preceitos do desenvolvimento agrário para uma localidade, pode-se construir uma estratégia de desenvolvimento rural, que ao encampar também os parâmetros ambientais, atinge-se o desenvolvimento rural sustentável.

Graziano da Silva (2002b) ressalta o fato de que é necessário analisar a situação do desenvolvimento agrícola brasileiro, principalmente no Centro-Sul do país, onde foram tomadas medidas que privilegiaram mais as dimensões técnicas e econômicas, em detrimento de mudanças mais de cunho social e política das pessoas do meio rural. O autor frisou que nesse contexto "cada vez mais importante no fortalecimento dos espaços locais, tem sido as exigências e preocupações crescentes com a gestão e a conservação dos recursos naturais" (GRAZIANO DA SILVA, 2002b, p. 434). Veiga (2002, p. 392) reforça este aspecto, quando menciona que a estratégia de desenvolvimento rural pode 
"por fim às práticas de exploração predatória dos imensos recursos naturais do país", em contribuição ao dinamismo da economia nacional.

Wanderley (2012, p.17) chama a atenção para as mudanças políticas e sociais que ocorreram na sociedade nos últimos anos, levando à formulação de novas visões de desenvolvimento, "inclusive de desenvolvimento rural, a partir de então apoiadas em novas referências teóricas e políticas, entre as quais as exigências a respeito do meio ambiente".

Kageyama (2008, p. 59) descreve que o modelo paradigmático da modernização agrícola vem sendo substituído, principalmente na Europa, por um novo modelo, o do desenvolvimento rural com objetivos calcados "na produção de bens públicos (paisagem), sinergias com ecossistemas locais, a maior valorização das economias de escopo em relação às economias de escala, e a pluriatividade das famílias rurais". De acordo com a autora, o desenvolvimento rural é um processo multi-nível, quando envolve diversos níveis de atuação; multi-atores, ao correlacionar várias instituições no processo; e multifacetado ao elencar "novas práticas, como administração da paisagem, conservação da natureza, agroturismo, agricultura orgânica, produção de especialidades regionais, vendas diretas, etc." (KAGEYAMA, 2008, p. 60).

Veiga $(2002$, p. 393) vislumbra nas relações citadas anteriormente a chance que as pessoas do meio rural podem ter de aproveitar "as sinergias latentes entre a agricultura familiar e as atividades dos setores terciário e secundário oferecem amplas oportunidades de ocupação e geração de renda", como por exemplo, o turismo realizado em áreas rurais.

Considerando a multifuncionalidade das atividades no espaço rural, Carneiro e Teixeira (2004) enfatizam a perda de importância das atividades agrícolas propriamente ditas nesse meio, principalmente no que se refere à fonte primordial na formação da renda das famílias. A perda da centralidade da produção agrícola no espaço rural e a diversificação das atividades levaram as pessoas à pluriatividade, o que propiciou outras práticas e valores sociais, culturais e econômicos para as sociedades locais e para os territórios. O agricultor já não é um mero "Homo economicus", mas "um ser social de múltipla inserção, sujeito a desejos e orientado por valores que não são reduzidos à lógica econômica" (CARNEIRO e TEIXEIRA, 2004, p. 35).

Nesse aspecto, a desvinculação da questão econômica revela uma identidade social das famílias rurais, mostrando "um modo de ser e de relacionar com o mundo e com a natureza", e o setor agrário passa a contribuir no fortalecimento do tecido social do campo com a permanência das pessoas em seus locais de origem, integrando a tradição de um lugar, em garantia da sua reprodução social e na 
"manutenção de um patrimônio social e cultural de um determinado território" (CARNEIRO e TEIXEIRA, 2004, p. 36).

No interior das propriedades ou de uma localidade, a cargo do processo de desenvolvimento rural, a agricultura pode nem ser considerada mais a principal fonte de receitas de um empreendimento rural, visto que o mesmo passa a englobar diversos aspectos: o econômico, relacionado à renda familiar; social, ligado ao nível de vida das famílias; e o ambiental, e que, as suas atividades apontam para a diversificação das atividades na geração da renda, que leva à pluriatividade (KAGEYAMA, 2008).

Por sua vez, os governos das localidades deveriam também atuar como facilitadores desse desenvolvimento, principalmente em regiões mais empobrecidas, como é o caso do objeto desse estudo, mais especificamente o Território da Chapada dos Veadeiros. Dessa forma "o desenvolvimento de um território depende em parte da organização e pactuação de sua sociedade em torno de objetivos comuns e de que essas condições podem ser construídas não implica o afastamento ou minimização do Estado" (ORTEGA e MENDONÇA, 2007, p. 118).

Em se tratando de uma base local ou regional, o desenvolvimento rural refere-se a uma base territorial, onde interagem diversos agentes e setores produtivos, daí a multissetorialidade e a multifuncionalidade do espaço rural. O caráter multifuncional confere, então, a esse espaço diversas funções

\begin{abstract}
A função produtiva, antes restrita à agricultura, passa a abranger diversas atividades, o artesanato e o processamento de produtos naturais e aquelas ligadas ao turismo rural e à conservação ambiental; a função populacional, que nos períodos de industrialização acelerada consistia em fornecer mão-de-obra para as cidades, agora invertem-se, requerendo-se o desenvolvimento de infraestrutura, serviços e oferta de empregos que assegurem a retenção da população na área rural; a função ambiental passa a receber mais atenção e demanda do meio rural à criação e proteção de bens públicos e quase-públicos, como paisagem, florestas e meio-ambiente em geral (KAGEYAMA, 2009, p. 250).
\end{abstract}

Miranda e Adib (2007) apontam que a amplitude multifuncional da agricultura vem sendo discutida pela Organização das Nações Unidas para Agricultura e Alimentos (FAO). Esta organização destaca não só a função econômica da agricultura e do espaço rural, como também as suas funções social e ambiental, estabelecendo uma fronteira entre a sociedade e a natureza.

Norder (2009), além das questões socioeconômicas do uso multifuncional do espaço rural, como o aspecto produtivo e o revigoramento das tradições nas comunidades rurais, sugere que novas combinações podem surgir aproveitando o espaço local para "a dinamização das interações 
econômicas e socioculturais com as demandas e investimentos urbanos voltados para o lazer, o turismo rural e ecológico" (NORDER, 2009, p. 81).

Mattos, Brondízio e Hercowitz (2011, p.125) reforçam esse âmbito multifuncional das atividades que envolvem as pessoas das localidades rurais, e frisam que deve haver uma maior interação entre os membros dessas comunidades, que necessitam de acesso aos serviços públicos em geral, a compreender as dimensões mercantis e não mercantis de suas atividades. Assim, sugerem que qualquer direcionamento de políticas públicas na área de serviços ambientais, não deve se restringir somente ao caráter técnico-produtivo, "tendo que considerar as relações e arranjos institucionais nos quais estão envolvidas as populações rurais" (MATTOS, BRONDÍZIO e HERCOWITZ, 2011, p.125).

A multifuncionalidade também pode gerar externalidades, um conceito de natureza econômica, no qual a ação de um agente influencia a atividade de outro no processo produtivo. Segundo Amédeé Mollard, citado por Kageyama (2008), as externalidades podem ser diretas, quando há uma complementaridade técnica ou econômica na produção; indiretas, mais difíceis de serem identificadas em um processo produtivo (como avaliar a importância de uma cultura agrícola para a biodiversidade) e; as "externalidades de localização, ou 'externalidades territoriais' (que) decorrem do efeito clássico de interação geográfica ou de proximidade, como a presença de recursos naturais nos territórios" (KAGEYAMA, 2008, p.71).

A autora sugere ainda que esses tipos de externalidades possam ser "aproveitados nos mercados localizados de produtos ou serviços de qualidade, que exploram recursos específicos do território com uma história e um patrimônio comum (em atividades como turismo e produtos regionais)" (KAGEYAMA, 2008, p.71).

Para Carneiro e Teixeira (2012, p. 91), a dimensão da multifuncionalidade no espaço rural induz a "uma visão integradora das esferas sociais no papel da agricultura e da participação das famílias rurais no desenvolvimento local". As outras funções da atividade (social e ambiental) se equiparam com a função produtivista (econômica) e se tornam relevantes ao permitir a uma comunidade manter práticas de sociabilidade, que por sua vez garante uma condição de vida e suas tradições, em contato com o seu meio, como afirmaram as autoras ao ressaltar "a sua importância como definidora de uma identidade social, de um modo de ser e de se relacionar com o mundo e com a natureza" (CARNEIRO e TEIXEIRA, 2012,p. 92).

A implantação de atividades não agrícolas no espaço rural tem lhe conferido novos atributos nesse processo de conversão de modos de agir sobre o próprio ambiente, como frisou Rodrigues (2012, p. 
227) "a sua ressignificação como lugar de lazer ou de preservação da natureza tem sido responsável por novas imagens e novos usos desse espaço". E não somente pelos usos que são feitos dessas localidades pelos visitantes, mas também ao propiciar uma melhor condição de vida em termos de renda, de comportamento, de infraestrutura, aos moradores dessas comunidades, inclusive como uma forma de fixação dessas pessoas no meio rural, com o oferecimento de oportunidades em seu local de origem, como assegura Carneiro (2012)

No caso deste estudo, a multifuncionalidade da agricultura contempla a situação por que passam os moradores do Distrito de São Jorge e seus arredores, no entorno do PNCV. Uma vez fixados numa área contígua a uma UC e numa região que, em suas condições naturais, também não propiciavam um bom desempenho na atividade agrícola, essas pessoas encontraram na função ambiental e nas atividades que dela derivam um meio de garantir a sua subsistência e se encaixar num contexto socioeconômico mais satisfatório.

Em um país onde é grande o número de residentes no meio rural que não têm condições, por diferentes motivos, de desenvolver uma agricultura comercialmente competitiva, nem de viver somente da atividade agrícola, a noção de multifuncionalidade permite reconhecer, estimular e valorizar formas de inserção social dessa população resgatando-lhe também um sentido de cidadania (CARNEIRO, 2009, p. 185).

Com a implantação do Parque Nacional, as pessoas da localidade deixaram de exercer algumas funções ligadas ao extrativismo de cristais de rocha de quartzo (garimpagem) e de plantas do cerrado e também as ligadas à agricultura de subsistência, que lhes garantiam a sobrevivência. A partir de então, começaram a se dedicar a novas atividades concernentes às dos objetivos da UC, dentre eles o de proteção ambiental, a atividade de suporte ao ecoturismo, envolvendo as comunidades locais, preferencialmente.

As atividades desenvolvidas nesse território se reconfiguraram. Tal fato remete aos termos multifuncionalidade do espaço rural e de território, tratados na Conferência das Nações Unidas sobre o Meio Ambiente e o Desenvolvimento (Eco-92), no Rio de Janeiro, que revelou, segundo Carneiro (2009, p.185), uma "preocupação com um rural não exclusivamente agrícola e com os significados não exclusivamente produtivos da prática agrícola", apontando para uma nova estratégia de desenvolvimento rural.

A partir do momento em que as atividades dos moradores da localidade se converteram para o fazer turístico, e mais especificamente para o ecoturismo, a questão ambiental, que envolve não só a vertente ecológica, mas também a social, tornou-se uma prática recorrente da localidade. Houve uma 
adequação dos fazeres das pessoas do local, tendo no aspecto ambiental um elemento para a mudança de suas ações. A exemplo do que afirmou Luchiari (2002, p. 118), "se a ecologia oferece chance de redefinir a política", essa, por sua vez, "fez uso da ecologia para definir os territórios". Surgiu uma oportunidade para a inserção socioeconômica dessas pessoas "em uma nova lógica de sobrevivência econômica para que não venham a ser mais um grupo de excluídos da sociedade" (LUCHIARI, 2002, p. 119).

Irving (2002) salienta que o turismo é um fenômeno complexo e surge como indutor de novas identidades das pessoas e o lugar onde o mesmo acontece não é um lugar apenas, mas o palco de conflitos e o cenário de transformações que abarca as intrincadas relações de seus atores sociais.

Nesse caso, a instalação do PNCV, em 1961, reconfigurou o modo de vida das pessoas do lugar e trouxe a presença de novos atores - os turistas - para o seu contexto. Uma nova visão da localidade em transformação sobressai, como destacou Irving (2002, p.72)

A reflexão sobre o lugar turístico emerge no contexto contemporâneo da resignificação do espaço rural, do reencantamento pela natureza, da prática de intervenção no lugar a partir do olhar e da demanda do não lugar, do "upgrade" da natureza como bem patrimonial de alto valor para as sociedades urbanas.

O PNCV redirecionou as atividades da população que habitava a área da Chapada dos Veadeiros. De garimpeiros, extrativistas e agricultores, as pessoas da localidade se viram de frente com as atividades do turismo, que começou a se desenvolver lentamente na região, no início dos anos de 1990. As pessoas do núcleo urbano do Distrito de São Jorge, bem como aquelas residentes na Zona de Amortecimento do Parque Nacional, se viram impelidas, por força da lei (leis e decretos que instituíram o Parque Nacional e passaram a normatizar a questão ambiental na região, entre elas a Lei de ${ }^{\circ}$ 9985/2000, que criou o Sistema Nacional de Unidades de Conservação - SNUC), a desempenhar atividades ligadas ao turismo, já que era uma opção colocada pelas circunstâncias, com a criação da Unidade de Conservação na região.

Houve uma reconfiguração do fazer cotidiano desses ex-garimpeiros, ex-agricultores, ex-donas-decasa, e outros, em um afã de se emoldurar numa nova atividade econômica que lhes garantisse o sustento sem, contudo, deixar a região. Não era uma atividade a mais no contexto do lugar, enquanto mais uma opção da pluriatividade, imposta pela modernização da agricultura (SCHNEIDER et al., 2009), e sim uma mudança no modo de atuar no espaço, em contato com outras pessoas, que passaram a usufruir dos bens e serviços do mesmo. 
A base especial de sua atividade não seria mais a propriedade ou o estabelecimento familiar, mas um território específico. Ele estaria atento a todas as alternativas de trabalho e as potencialidades apresentadas em um território. O sucesso profissional desse novo personagem dependeria da construção de uma rede interdependente de atores sociais que atuaria em um mesmo território, inclusive para a formação de novos mercados sustentados na relação pessoal entre produtos e consumidor (CARNEIRO, 2009, p.182).

Os atores desse processo são agora os turistas, os condutores de visitantes, os donos de pousadas, de áreas de camping, de restaurantes, de estabelecimentos comerciais e outros, que dão suporte a uma nova atividade. Nesse caso, o ecoturismo transformou-se no principal indutor das atividades abertas ao uso público, desenvolvidas no Parque Nacional, sendo uma das prerrogativas de sua função, e também impulsionou a atividade no Distrito de São Jorge e nas suas adjacências, na Zona de Amortecimento do PNCV, proporcionando condições de reprodução econômica e social das pessoas da comunidade.

\subsection{AS IMPLICAÇÕES DA CRIAÇÃO DE UMA UNIDADE DE CONSERVAÇÃO EM UM TERRITÓRIO}

Ao explorar demasiadamente o meio onde vive, para satisfação de suas necessidades, o homem causa a depleção dos recursos naturais e problemas na sua relação com o meio ambiente, conforme expôs Hauff (2004, p. 1): “desde as sociedades extrativistas e agrícolas pré-industriais até as tecnologicamente mais desenvolvidas, via de regra, os sistemas humanos retiram mais do ambiente do que este pode repor".

Um exemplo desse processo pode ser citado no caso da expansão da fronteira agrícola, principalmente no cerrado brasileiro, fruto da modernização da agricultura, que levou ao meio rural uma "reconversão tecnológica e produtiva, de (re)socialização social, cultural e ambiental” (DUARTE, 1998, p. 12).

No tocante à questão ambiental, Braga e Pires (2002) destacaram alguns estudos realizados por Organizações Não Governamentais (ONG) - (entre elas a Fundação Pró-Natureza - FUNATURA) - em que se ressaltou a importância da biodiversidade do cerrado, valorizando-o por suas características ecológicas e sociais, pelos povos que aí habitam. Houve um deslocamento da abordagem do tema, como apontam os autores (2002, p. 35) "a pauta saiu do espaço urbano e conduziu as discussões para os ambientes não-urbanos, se não propriamente rurais", em que as preocupações deixaram de ser somente em função das questões produtivas da agricultura e passaram a ser também focadas no meio ambiente.

Nesse aspecto, Pimbert e Pretty (2000) assinalam que a busca pela conservação ambiental tornou-se um foco importante no desenvolvimento rural, ao sustentarem que existe uma relação inversa entre 
as ações humanas e a saúde do ambiente, mencionando problemas advindos da agricultura como a erosão do solo, degradação de pastagens, desertificação, perda de florestas e a destruição da vida selvagem.

Para a contenção, ou a minimização, de problemas como esses, relacionados com a expansão da fronteira agrícola ou de outras atividades humanas, encontrou-se uma forma de proteger as áreas naturais, com a finalidade de conservar as espécies e comunidades biológicas, bem como de manter as suas belezas cênicas, instituindo-se a criação das unidades de conservação (MENDES, 2009). Seabra (2012) relaciona a criação dessas áreas à intensificação do consumo das pessoas que sobrecarregam a exploração dos recursos naturais e, em resposta os governos de vários países criaram tais unidades para resguardar tais recursos da ação humana.

No Brasil, a Lei $n^{\circ}$ 9985, de 18 de julho de 2000 e o Decreto 4340 foram criados para regulamentar o artigo 225 da Constituição Federal e instituir o SNUC, que categoriza as unidades de conservação, quanto aos seus objetivos de conservação e formas de uso dos recursos ambientais (BRASIL, 2009).

De acordo com o SNUC (BRASIL, 2000), as diferentes categorias de unidades de conservação organizam-se em função de seus objetivos de manejo e tipos de uso: UC de Proteção Integral e de Uso Sustentável. As primeiras têm o objetivo primordial de preservação da natureza, em que se admite o uso indireto de seus recursos naturais e se subdividem em: Parques Nacionais, Reservas Biológicas, Estações Ecológicas, Monumento Natural e Refúgio de Vida Silvestre.

As unidades representantes do segundo grupo tem como objetivo a conservação da natureza com o uso direto de seus recursos naturais e se subdividem em Área de Proteção Ambiental, Floresta Nacional, Reserva Extrativista, Reserva de Fauna, Área de Relevante Interesse Ecológico, Reserva de Desenvolvimento Sustentável e Reserva Particular do Patrimônio Natural (BRASIL, 2000).

No caso específico deste trabalho, o enfoque será dado à categoria dos Parques Nacionais. Conforme Diegues (2001), a primeira unidade dessa natureza surgiu em 1872, na região nordeste de Wyoming, EUA, o Parque Nacional de Yellowstone, "primeiro exemplo da preservação de grandes áreas naturais de interesse público" com o objetivo de "proteger áreas naturais de grande beleza cênica para usufruto dos visitantes (de fora da área)" (DIEGUES, 2001, p. 99). Esse modelo espalhou-se para outras regiões do mundo e chegou em terras brasileiras. 
No Brasil, os Parques Nacionais foram instituídos pela Lei de $n^{\circ} 4771$, de 15 de setembro de 1915, mas o primeiro só foi criado em 1937, o Parque Nacional do Itatiaia, no Rio de Janeiro, visando a promoção da pesquisa científica e o turismo (MARTINS, 2011).

Pelo que dispõe o SNUC, em seu artigo 11, um Parque Nacional

tem como objetivo básico a preservação de ecossistemas naturais de grande relevância ecológica e beleza cênica, possibilitando a realização de pesquisas científicas e o desenvolvimento de atividades de educação e interpretação ambiental, de recreação em contato com a natureza e de turismo ecológico (BRASIL, 2000, s/p).

Para Hauff (2004, p. 2), além dos objetivos explicitados no SNUC, as áreas das UC "são espaços que protegem recursos naturais desconhecidos ou pouco conhecidos que poderão vir a tornar-se úteis à humanidade como novos medicamentos, alimentos ou modelos para a melhoria de tecnologias". Mendes (2009) acrescenta que o estabelecimento dessas áreas de proteção em uma localidade, além de surtir um efeito positivo de conservação da biodiversidade, atua em outra frente, de contenção das atividades humanas que ameaçam um ambiente, ao que afirma

os parques têm se mostrado extremamente eficientes na proteção da biodiversidade e dos ecossistemas nas florestas tropicais, especialmente para conter o desmatamento. No Brasil, a criação de parques e estações ecológicas foi crucial em determinados locais para a manutenção de ecossistemas que seriam dizimados, seja pela expansão agropecuária, seja pelo aumento das cidades e urbanização dos espaços (MENDES, 2009, p. 77).

Além dos limites estabelecidos para uma UC, no caso um Parque Nacional, deve-se considerar a região de seu entorno, para que as pressões citadas anteriormente não interferiram no ambiente natural da unidade. Por esse motivo a lei que institui o SNUC preconiza a criação de uma região que confronta essas unidades, com a finalidade de amenizar a pressão do ambiente externo, denominada Zona de Amortecimento e a define como "o entorno de uma unidade de conservação, onde as atividades humanas estão sujeitas a normas e restrições específicas, com propósito de minimizar os impactos negativos sobre a unidade" (BRASIL, 2009, p.391).

Segundo Pereira et al. (2004), a Zona de Amortecimento ou Zona de Buffer no entorno de uma UC tem a finalidade de protegê-la das atividades antrópicas circunvizinhas. Dessa forma, nessas localidades, as atividades econômicas das pessoas deveriam estar em consonância com as atividades de conservação dos recursos naturais, fato que deve reverter o modo de agir daqueles que aí habitavam, obrigando-os a buscar uma nova forma de sobrevivência e desenvolver outras atividades, que não as tradicionais ou de costume que normalmente desempenhavam. 
O dimensionamento de uma Zona de Amortecimento segue o que está disposto no plano de manejo da UC, caso esse limite não esteja fixado, deve orientar-se pelo parágrafo $2^{\circ}$, do artigo $1^{\circ}$, da Resolução $n^{\circ} 428$ do Conselho Nacional do Meio Ambiente - CONAMA, de 17 de dezembro de 2010, que estabelece "o licenciamento de empreendimento de significativo impacto ambiental, localizado numa faixa de 3 mil metros a partir do limite da UC". Em se tratando de "empreendimentos não sujeitos a EIA [Estudo de Impacto Ambiental]/RIMA [Relatório de Impacto Ambiental], o órgão ambiental licenciado deverá dar ciência ao órgão responsável pela administração da UC, quando estiver localizado no limite de até 2 mil metros da UC", conforme o inciso III, do artigo $5^{\circ}$ da mesma resolução (BRASIL, 2010).

O SNUC ao mesmo tempo em que restringe as atividades humanas na Zona de Amortecimento, para evitar impactos diretos às UCs, por outro lado redireciona essas atividades para iniciativas que tenham caráter sustentável, quando explicita pelo menos dois objetivos intimamente ligados à questão do desenvolvimento socioeconômico das comunidades adjacentes a essas unidades:

- promover o desenvolvimento sustentável a partir dos recursos naturais;
promover a utilização dos princípios e práticas de conservação da natureza no
processo de desenvolvimento.
- proteger os recursos naturais necessários à subsistência de populações
tradicionais, respeitando e valorizando seu conhecimento e sua cultura e
promovendo-as, social e economicamente (BRASIL, $2000, \mathrm{~s} / \mathrm{p}$ ). De acordo com o Plano de Manejo do PNCV (BRASIL, 2009, p. 392), dentre os objetivos que norteiam o estabelecimento da Zona de Amortecimento, destaca-se a vinculação da atividade agrícola com um desenvolvimento mais sustentável: "estimular dirigentes e produtores a empregarem técnicas menos predatórias que associem o desenvolvimento econômico à conservação da natureza".

Para Hauff (2004), essas áreas também podem ser denominadas de Zona Tampão, e possuem importância tanto para o isolamento das comunidades de seres vivos do interior da UC quanto para integrar-se às comunidades de fora da unidade, principalmente as pessoas que aí habitam.

\begin{abstract}
Neste contexto, as suas áreas periféricas desempenham importante papel, tanto para proteger a unidade dos usos externos, como para promover atividades produtivas que sejam culturalmente aceitas, permitam a manutenção econômica das comunidades humanas e mantenham os recursos essenciais e o funcionamento do sistema (HAUFF, 2004, p. 2).
\end{abstract}

Consoante ao que afirmou a autora anteriormente, o Plano de Manejo do PNCV (BRASIL, 2009, p. 392) assinala como objetivo da Zona de Amortecimento, relacionado aos moradores aí residentes, "sensibilizar as comunidades acerca das atividades de preservação e conservação do Parque", bem 
como estabelece em suas normas específicas, que "deve-se buscar a inserção das comunidades residentes na zona de amortecimento nas atividades de educação ambiental desenvolvidas pela UC e seus parceiros" (BRASIL, 2009, p. 393).

Hercowitz, Mattos e Souza (2011, p. 252) veem como fato positivo na criação dessas zonas, a possibilidade de aproximação entre as pessoas locais e as unidades, visto que "as zonas de amortecimento, além de desempenharem a função de faixa de contenção da degradação antrópica, também podem ser instrumentos na promoção da integração entre populações vizinhas e as Unidades de Conservação".

Embora na definição do que seja zona de amortecimento e no próprio Plano de Manejo da UC conste que seja uma área de transição entre a unidade e seu meio externo, e que exista uma preocupação com as pessoas que nesse local residam, alguns estudiosos mencionam, que o estabelecimento dessas zonas reforça mais a questão espacial da sua demarcação do que com a preocupação com as comunidades que aí residam (HAUFF, 2004).

Guanaes (2006) também salienta que o SNUC propõe uma "relação eficaz e harmoniosa entre populações locais, a natureza e os agentes externos", que devem constar nos planos de manejo das UC, por intermédio de um zoneamento, do qual a Zona de Amortecimento faz parte. Esse procedimento, segundo a autora tem levado em consideração aspectos mais técnicos e ecossistêmicos, não contemplando "valores e critérios locais de acesso e uso dessas áreas; o que tem afetado (in) diretamente, e às vezes de modo perverso, a vida da população que depende do uso dos recursos naturais dessas áreas para sua sobrevivência" (GUANAES, 2006, p. 196).

Esse aspecto de relacionamento das comunidades com as UC é tratada de forma mais aprofundada por Diegues (2001). A instalação de áreas naturais protegidas em territórios ocupados por comunidades já residentes em uma determinada localidade, ocupa o espaço onde estas já exerciam anteriormente o seu modo de vida.

Essa atividade é vista pelos moradores locais como um roubo de seu território que significa uma porção da natureza sobre o qual eles reivindicam direitos estáveis de acesso, controle ou uso da totalidade ou parte dos recursos aí existentes (DIEGUES, 2001, p. 65).

Pode-se observar uma vinculação entre essas pessoas e o espaço que pleiteiam, pois, conforme destacam Pereira e Diegues (2010, p. 40), "são descendentes dos grupos que durante o período da colonização do território se estabeleceram em regiões isoladas de centros econômicos e de desenvolvimento". Esse elo com as localidades permite uma percepção mais apurada da realidade do 
ambiente onde essas populações se encontram inseridas, resultado de "uma forte ligação com suas terras, expressa pela lei consuetudinária, pelo sistema simbólico e pelo conhecimento detalhado dos recursos naturais" (COLCHESTER, 2000, p. 239).

Para essas comunidades locais, distintas das sociedades urbano-industriais, "o território é descontínuo, marcado por vazios aparentes (terras de pousio) e tem levado autoridades da conservação a declará-lo parte das 'unidades de conservação' porque 'não é usado por ninguém'” (DIEGUES e NOGARA, 1999, p. 37). Esse fato levou e leva ao conflito os moradores locais e autoridades, pela reivindicação e posse da terra nessas localidades.

Para Guanaes (2006, p. 39), essa forma de apropriação do espaço para a instalação de uma UC "é naturalmente potencializadora de conflitos e tensões, visto que sobrepõem territorialidades diferentes [...] Os parques nacionais como outras unidades de conservação no Brasil são territórios de múltiplos poderes, lugares e subjetividades superpostas".

No caso em estudo, essa situação foi marcada quando da criação do Parque Nacional da Chapada dos Veadeiros, numa região em que o sistema de aquisição de terra foi caracterizado pelo apossamento, principalmente pelos pequenos produtores, como afirma Bezerra da Silva (1998, p. 205)

De acordo com informação veiculada pelo cartório (de Alto Paraíso de Goiás), há, no Parque Nacional, uma faixa de domínio de aproximadamente 10 mil metros, delimitada e protegida pela legislação, mas que se encontra ocupada por diferentes tipos de posse.

Essa ocupação tem gerado tensão entre os posseiros - extratores de cristais pois, quando foi criado o Parque Nacional, não houve nenhum tipo de desapropriação menos ainda, de indenização.

Esse fato pode ser corroborado pelo que relata Diegues (2001, p. 121), que nas desapropriações realizadas em outros locais para a instalação de UC, "os moradores locais que usualmente não têm como regularizar sua posse quase nada ganham na desapropriação. Pior do que isso, em sua maioria, esses moradores não são indenizados, mas são proibidos de exercer suas atividades tradicionais".

Silva (2003b) retrata as percepções das pessoas a respeito do PNCV e aponta que o mesmo modificou os hábitos das pessoas da localidade, e no seu entorno: "a implantação do Parque tirou, além do garimpo, um outro meio de trabalho e sobrevivência, no caso a agricultura" (SILVA, 2003b, p. 75).

Neste caso, em se tratando de uma atividade de garimpagem, não era uma prática que estivesse associada à conservação da natureza. Novaes (2002, p. 24) aponta que a garimpagem do cristal apresentava um significativo impacto ambiental, "pois a mineração demanda(va) a retirada da 
cobertura vegetal e escavações profundas, das quais até hoje se podem ver testemunhos dentro do Parque Nacional e em outras áreas".

Essa prática como outras relacionadas às populações locais, mesmo que de certa forma, garantindo equilíbrio aos ecossistemas onde eram realizadas, não se revestiam de uma visão romântica do "bom selvagem", como asseguram Pereira e Diegues (2010). Contudo, associadas à atividade de garimpagem encontravam-se outras práticas como a da agricultura de subsistência, do extrativismo de plantas do cerrado, entre outros, que de certa forma mostravam um vínculo das pessoas com seu espaço natural, no respeito às estações do ano, do tempo de plantio, das floradas e frutificação da vegetação nativa, da reprodução dos animais, etc. Rodrigues e Fredrych (2013, p. 74) destacam que as populações nativas "têm um compromisso assumido há séculos com a natureza, onde são respeitados os tempos, os desgastes, os clamores do meio ambiente".

Esses momentos marcam uma relação de seguimento ao compasso natural das atividades e podem se manifestar nas suas tradições, nos saberes repassados através dos tempos. Guanaes $(2006$, p. 23) pondera, em estudo realizado na Chapada Diamantina - BA, que não sendo a "atividade garimpeira portadora de maior equilíbrio ecológico", a "relação entre o garimpeiro e o mundo natural é medida por sentimentos de medo e respeito", expressos na sua atividade, nas festas e rituais religiosos.

Castro (2000) afirma que nas sociedades tradicionais a organização da atividade do trabalho não se separa de rituais sacros das festividades ou sociabilidade grupal. São "manifestações sociais que, em última análise referem-se a lugares, ao território, colocando em destaque o regime dos rios, a reprodução das espécies e o ritmo da natureza" (CASTRO, 2000, p. 168). Nesse aspecto vão se criando nessas sociedades condições para a garantia de sua reprodução socioeconômica e o estabelecimento de uma cultura, como também uma maior integração com o ambiente.

Esses elementos remetem a uma reflexão sobre a coexistência entre o homem e o meio no qual está inserido, e podem mostrar que "o manejo dos recursos naturais desenvolvidos pelas populações tradicionais e proporcionado pela acumulação dos conhecimentos transmitidos ao longo do tempo entre as gerações contribui para o fortalecimento da biodiversidade" (PEREIRA e DIEGUES, 2010, p. 46), como também para estreitar a relação homem-natureza.

A partir dos anos de 1990, os órgãos responsáveis pela gestão das áreas protegidas brasileiras, primeiramente o IBAMA, e depois de 2007, o Instituto Chico Mendes de Conservação da Biodiversidade (ICMBio) colocaram na pauta de suas ações a estruturação dos planos de manejo das UC, e sua integração com as comunidades de seus entornos. Segundo Hauff (2004), com o objetivo de 
assegurar a integração da unidade com as Zonas de Amortecimento e áreas de influência, nos planos de manejo passaram a constar características socioeconômicas dos municípios abrangidos por uma determinada UC, bem como ações de extensão para serem desenvolvidas com as populações locais.

Outra forma de encaixar as populações locais com os objetivos das UC se deu por meio do envolvimento das pessoas nas suas atividades, principalmente na prestação de serviços relacionados ao turismo. "O ecoturismo transformou-se hoje num grande negócio e a distribuição da renda gerada com as comunidades locais tem sido um meio popular pelo qual os conservacionistas esperam reconciliar os povos nativos com as áreas protegidas" (COLCHESTER, 2000, p. 245).

Um exemplo que ilustra os benefícios que a atividade turística pode se estender às populações vizinhas das áreas protegidas, vem de Uganda, na África, onde o governo local delegou à Ugandan Wildlife Authority (Autoridade Ugandense de Vida Selvagem - UWA) repassar 20\% de todas as receitas do turismo nessas áreas para as suas comunidades vizinhas, permitindo a melhoria das condições locais e de preservação da biodiversidade e reforçando os meios de subsistência rural (EUROPEAN COMMUNITIES, 2008).

Os governos, via de regra, são os responsáveis pela proposição das políticas da área ambiental, em parcerias com diversas entidades, ONG, associações locais, entre outras. Além disso, deve-se contar com o envolvimento das pessoas que residem nas localidades, que passam a ser os protagonistas de qualquer intervenção, nos moldes como sugere Diegues (2000, p. 121), "essa participação das comunidades locais implica estimular sua organização mediante criação de associações locais. 0 Estado deve considerá-las interlocutoras privilegiadas nesse aspecto participativo".

Guanaes (2006) corrobora esse caráter organizacional das pessoas residentes, em parceria com os gestores públicos, na administração do uso dos bens e serviços ambientais.

Nesse sentido, a gestão conjunta entre grupos locais e órgãos públicos tem representado uma estratégia possível para que as populações sejam mantidas em seus espaços. Visto que a 'co-gestão' implica também em uma auto-gestão dos grupos sociais no manejo dos recursos disponíveis (GUANAES, 2006, p. 202).

Na Chapada dos Veadeiros, quando a atividade turística começou a se estruturar, no início dos anos de 1990, houve uma mudança nos fazeres das pessoas, principalmente dos ex-garimpeiros, que deixaram a garimpagem para se tornarem condutores de visitantes nas trilhas abertas ao público no interior do PNCV. Organizados em uma associação, com apoio do IBAMA, à época o órgão do governo federal administrador do Parque Nacional, por meio do Programa Nacional de Meio Ambiente (PNMA) 
e do Programa de Execução Descentralizada (PED) e de algumas organizações não-governamentais, essas pessoas receberam capacitação para atuarem na condução de visitantes, como também para dar suporte em algumas atividades da UC, atuando na manutenção da mesma, executando manutenção de trilhas, participando das brigadas de incêndio, entre outros.

Esse arranjo, baseado em "acordos mais ou menos informais com instituições oficiais do meio ambiente", como qualificou Diegues (2001, p. 120), propiciou aos moradores locais uma forma de subsistência no seu ambiente, porém com reconversão de suas atividades. Para Ribemboim (2004, p. 6), foi "uma estratégia de gerenciamento ao mesmo tempo inovadora e ética, rompendo com antigos modelos de exploração e aproveitamento dos recursos naturais de uma microrregião às custas do desconforto e da desagregação das comunidades ali estabelecidas".

Assim, algumas considerações devem ser feitas quanto ao fato da presença de uma UC em uma determinada localidade. Porquanto deve-se ressaltar que além dos seus objetivos de "manutenção da diversidade biológica" e da proteção dos recursos abióticos que lhe dão suporte, é necessário observar, como frisou Seabra (2013, p. 27), que a mesma garanta a promoção do "desenvolvimento sustentável a partir dos recursos naturais" de uma região, sem contudo deixar de "proteger as comunidades tradicionais, respeitando e realizando sua cultura e promovendo-as social e economicamente".

Uma das formas de se materializar essas propostas, que constam das prerrogativas do SNUC, seria o processo de alavancagem do ecoturismo que uma UC pode desenvolver, contribuindo com as regiões onde se encontra, em particular, porque essas são localidades indicadas para a conservação da natureza e o trabalho com a terra se volta para esse fim, ou ainda cuja atividade agrícola é incipiente. Dias (2003, p. 132) elucida essa situação, mostrando que o turismo pode levar "à diversificação da economia local, em especial nas zonas rurais e no entorno, em que o emprego na agricultura é esporádico e insuficiente".

Todavia, é importante ressaltar que na condução dos trabalhos de administração e manutenção dessas UC não se deve deixar de considerar a presença e a proximidade das populações residentes nesses locais, porque de certa forma essas pessoas "armazenaram vasto conhecimento empírico do funcionamento do mundo natural em que vivem" (DIEGUES, 2001, p. 159) e podem contribuir com o processo de conservação.

A articulação entre os meios natural e social, relacionando conhecimentos tradicionais e conservação dos recursos naturais pode trazer "importantes contribuições para a compreensão do funcionamento 
destes sistemas complexos, e, por conseguinte, para melhoria na administração e proteção dessas áreas", como asseguraram Pereira e Diegues (2010, p. 48), numa estratégia de negociação que garanta a conservação da "bio-sócio-diversidade" (DIEGUES e NOGARA, 1999).

O autor frisa que é necessário uma movimentação via sociedade que proponha o respeito à "diversidade cultural" baseada na conservação da "diversidade biológica", com a participação de todos os envolvidos, "na gestão dos espaços territoriais" (DIEGUES, 2001, p. 158). Comunidades tradicionais, populações locais, residentes, administradores de UC, governos, grupos de apoio, devem se integrar nessa questão da conservação dos recursos naturais, "reinventando cotidianamente os valores que os mantêm ligados à natureza", como destacou Guanaes (2006, p. 203), para a busca de soluções para esses problemas socioambientais.

\section{CONTEXTUALIZAÇÃO HISTÓRICA DA CHAPADA DOS VEADEIROS: (IM)POSSIBILIDADES E POTENCIALIDADES}

\subsection{DA TERRA DE GARIMPO A PARQUE}

As primeiras referências da colonização da região que atualmente denomina-se a Chapada dos Veadeiros datam do século XVIII. No século anterior, porém, se tem menções de exploradores que, utilizando os rios da ecorregião dos cerrados, a ela afluíram por intermédio das bacias do Prata, do São Francisco e Amazônica, mais especificamente os rios Tocantins e Araguaia. As incursões eram provenientes das explorações dos bandeirantes e das fazendas de gado que foram se formando até o rio Paranã (ALBUQUERQUE, 1998; BERTRAN, 2002; MARTINS, 2011).

Bertran (2002) faz alusão à passagem do bandeirante Bartolomeu Bueno da Silva (Anhanguera filho) e sua expedição pela região, onde hoje se situa Alto Paraíso de Goiás, nas imediações do rio São Bartolomeu da Chapada, e destaca que a mesma começou a ser ocupada em meados do século 18, quando da chegada dos primeiros desbravadores nas terras circunvizinhas de Arraias e Paranã.

A descoberta de ouro na região da Chapada levou a fundação do arraial em 1740, que em dias atuais é o município de Cavalcante, a primeira cidade do local, tanto que, segundo Behr (2000), no primeiro mapa da Capitania de Goiás, a região é denominada de Chapada de Cavalcante.

A atividade aurífera, por sua vez, fez surgir a agricultura de subsistência, para o abastecimento de seus trabalhadores, paralelamente à atividade das fazendas de criação de gado e de cultivo de trigo, 
introduzido na região por imigrantes egípcios provenientes da Bahia (BEHR, 2000; SILVA, 2003a; OLIVEIRA, 2007).

Dessas atividades, segundo Oliveira (2007, p. 39), "a pecuária extensiva é a atividade que melhor caracteriza o processo de ocupação da Chapada, principalmente a partir da decadência da mineração de ouro e também do cultivo do trigo". Behr (2000) complementa, ao relacionar o manejo da atividade com a ocupação territorial da localidade

A atividade se instalou na Chapada a partir da segunda metade do século 18 , sempre na época da seca, quando queimavam os campos para a rebrota do capim. O gado aproveitava os minerais das cinzas e alto valor proteico das gramíneas novas. Esta prática determinou o povoamento das regiões altas, dando origem a fazendas e povoados de criadores de gado que vinham do vão do Paranã (BEHR, 2000, p. 55-56).

A atividade tritícola teve uma importância para a região e se manteve expressiva até o final do século XIX, sendo responsável pelo surgimento dos povoados do Moinho e Bonsucesso (ALBUQUERQUE, 1998; OLIVEIRA, 2007). De acordo com BEHR (2000), Heitor Cordeiro, agente da Inspetoria Agrícola do Estado de Goiás, em um trabalho de 1935, Contribuição ao estudo da cultura do trigo em Goiás, atribuiu o êxito da cultura na Chapada "ao clima favorável e ao fracasso da atividade de exploração do ouro, o que levou os moradores da região a priorizarem a agricultura" (BEHR, 2000, p. 56).

Albuquerque (1998, p. 234-235) também destaca os elementos que garantiam a migração para as atividades agrícolas na região da Chapada, à época, principalmente no vale do Rio São Bartolomeu, "o ambiente úmido e abrigado do vale, a abundância de cursos de água de sua microbacia e, sobretudo, os solos férteis de seus platôs [...] o clima temperado, devido à altitude e à sazonalidade das chuvas, próprio da ecorregião".

Entretanto, Behr (2000) assinala que, já no início do século XX, a produção de trigo findou-se em decorrência dos seguintes fatores: "transporte inadequado, falta de chuva, inexistência de apoio oficial e concorrência com o cristal" (BEHR, 2000, p. 58).

O autor ressalta ainda a produção de couros de veados na região, atividade que predominou nos séculos XVIII e XIX, produto que era destinado à exportação. Os fardos de couro eram transportados até o porto de Belém, passando por entre trilhas das serras e o rio Tocantins; ou abastecia o mercado de calçados de Minas Gerais, via Formosa (GO), denominada à época de Couros. O material também era utilizado na mineração, para retenção do ouro. Seu enfardamento ocorria às margens de um rio, o rio dos Couros, indicativo dessa atividade (BEHR, 2000). 
O surgimento de Alto Paraíso de Goiás ocorreu por volta do ano de 1750, próximo às nascentes do rio São Bartolomeu, onde se estabeleceu um pequeno núcleo de colonização, formado por um grupo de fazendas, com cultivo de café e criação de gado, denominado de Veadeiros, situado à beira da estrada que ligava o sul do estado de Goiás até as regiões de Cavalcante e de Palmas (ALBUQUERQUE, 1998; BEHR, 2000).

A designação Veadeiros, segundo Behr (2000), apresenta duas versões: "uma devido à grande quantidade de veados campeiros que tinham ali seu habitat; outra em homenagem ao cachorro utilizado pelos caçadores para farejar e perseguir o animal durante as caçadas" (BEHR, 2000, p. 53).

Em 1938, o povoado passou a condição de distrito de Cavalcante, quando tomou posição de frente no vale do São Bartolomeu e, em 1953, o mesmo foi elevado à categoria de município, ainda sob o nome de Veadeiros, passando a denominar-se Alto Paraíso de Goiás, em 1963 (ALBUQUERQUE, 1998; BEHR, 2000).

Mesmo com a municipalização da localidade, o caráter administrativo em nada interferiu nas bases sociais e econômicas da região, o município, como aponta Albuquerque (1998, p. 240), mantinha "uma larga dominância de população habitando a área rural, em fazendas e sítios cujo aparato e dinâmica produtiva encontra(va)m-se mergulhados nos séculos passados".

A ocupação do espaço na região seguiu os moldes da lógica aplicada ao estado de Goiás e CentroOeste, em geral, que passou, por um lado, da mineração para uma economia agrícola de cunho regional, visando a subsistência dos arraiais. E de outro, a pecuária extensiva de corte transformou-se na atividade dominante, uma vez que dispensava uma maior utilização de mão-de-obra e também pelo fato da inexistência de capital para investimento, com incipiente comercialização, restringindose a poucos contatos com certas regiões do Nordeste brasileiro (ESTEVAM, 2004).

Esse fato pode ser evidenciado com o que relatou o morador A do Distrito de São Jorge, que ainda nos anos de 1930, confirmava essa relação comercial com a região Nordeste e também a forma de como era feito o seu transporte:

Eu vim prá Goiás, prá Taguatinga (aqui, hoje, de Tocantins) foi em 1938. Nós viemos prá aí, o meu pai comprava boi e vendia na Bahia. Naquele tempo não existia carro, era ni tropa, tocá boi (morador A, ex-garimpeiro, entrevista mar./2013).

Segundo Doles (1995), muitos desses arraiais tiveram suas populações diminuídas, e a vida na capitania ruralizou-se sob a "égide da pecuária", constituindo um vazio demográfico do meio-norte e norte do estado de Goiás (que na época incluía o atual estado do Tocantins). 
As comunidades da Chapada dos Veadeiros, bem como de todo o norte do estado, afastados do eixo viário que se dirigia a São Paulo, ficaram submetidas a um total isolamento, reforçando o processo de formação e de desenvolvimento das pequenas comunidades sertanejas do território brasileiro (ALBUQUERQUE, 1998, p. 234).

No limiar do século XX, a situação na Chapada ganhou outros contornos, diferentes daqueles que a exploração da pecuária ditara, e a socioeconomia se voltara novamente para a garimpagem, principalmente numa localidade situada a oeste do povoado de Veadeiros, com a descoberta de cristal de rocha, o quartzo. De acordo com Martins (2011), esse mineral combina em sua estrutura átomos de Silício (Si) e Oxigênio (O) e apresenta cores variadas, conforme as incrustações de outros elementos, sendo que o hialino, incolor, possui apenas Silício e Oxigênio na sua composição. "Na Chapada dos Veadeiros, a variedade mais abundante é o quartzo hialino, ocorrendo também o quartzo róseo" (MARTINS, 2011, p. 12). Oliveira (2007) associa a atividade da mineração desse cristal de rocha a uma demanda internacional da indústria eletrônica de equipamentos de guerra, apresentando picos de exploração no período das guerras mundiais e entrando em declínio após a guerra da Coreia, em meados dos anos de 1950.

De certa forma, esses achados contribuíram para o afluxo de pessoas para a região, como atesta Behr (2000, p. 59), "nas primeiras décadas deste século (XX), o povoamento da Chapada dos Veadeiros deuse também em função da exploração das jazidas de cristal de rocha, notadamente no povoado de São Jorge - antigamente denominado de Baixa dos Veadeiros". Pessoas de várias regiões dirigiram-se para o local, como destaca Silva (2003a, p. 39), "em 1912, a mineração de cristal de rocha ensejou a migração de levas de garimpeiros, oriundos, principalmente, dos sertões mineiros e baianos para a área do hoje Parque Nacional da Chapada dos Veadeiros e seus arredores".

Um garimpeiro, José Raimundo de Oliveira, relatou em um caderno de memórias, o local onde também, segundo depoimentos de outros ex-garimpeiros, foi o primeiro acampamento de garimpagem na região:

Como certo, depois do primeiro Salto do Rio Preto, numa planada muito bem configurada, acharam cristal. Ali fizeram a primeira exploração, muitas descobertas, jazidas riquíssimas, muito cristal. Jazidas descobertas em lugares que não tinham nome ainda. Decorrido um ano, eles deram um salto à esquerda do Rio Preto, acima do Salto das Cachoeiras, na serra à frente. $E$ fizeram a primeira exploração, já no ano de 1912. Apesar de já ter exploração dos antigos, ninguém sabe informar quem foi e em que ano. Nome do lugar: Garimpão (OLIVEIRA, 2009, p. 19-20).

Esse primeiro acampamento, que segundo relatos de ex-garimpeiros, chegou a abrigar entre duas e três mil pessoas, permaneceu ativo às margens do Rio Preto até que um incêndio o destruiu, entre os 
anos de 1949 e 1950. "Acabou, queimou tudo, foi um prejuízo danado", consumindo os seus ranchos de palha e capim e um barracão grande, afirmou o morador B e ex-garimpeiro (entrevista em mar./2013).

Outro acampamento foi montado, onde atualmente se situa o Distrito de São Jorge, iniciando o seu povoamento, conforme relata Oliveira (2009, p. 26): “De 1950 a 51, Matias Brasil, depois do incêndio do armazém, fez mudança do Garimpão para a planada da Baixa, trazendo seu estoque de mercadorias". Outras pessoas da região se deslocaram para a localidade, juntando-se aos garimpeiros. Chegantes de outras partes do estado de Goiás e de outros estados, para formar um novo povoado, que a partir de 1953, passou a denominar-se Vila de São Jorge (PM de Alto Paraíso de Goiás, 1998). Nessa nova configuração os moradores "se estabeleceram em barracos mais trabalhados e arruados (formando ruas) com implantação de locais de comércio" (BRASIL, 2009, p. 22).

Na região do Distrito de São Jorge encontravam-se vários pontos de garimpagem, tanto que na área do PNCV, de acordo com o seu Plano de Manejo (BRASIL, 2009), existem atualmente cerca de 34 jazidas fechadas, constituindo um sítio histórico-cultural de grande valor turístico e educativo, por onde passa a trilha que conduz aos Saltos do Rio Preto, conhecidos como Saltos do Garimpão.

O sistema de propriedade da terra era o apossamento, como indicou o morador C (entrevista em mar./2013), "naquele tempo, as pessoas aposseavam, o garimpeiro, por exemplo, saia daqui, ia daqui para Alto Paraíso, chegava na beira da estrada, achava um lugar bonito e fazia uma casa, e ali era tipo uma posse". Essa era a prática costumeira na região, onde as terras eram devolutas e as próprias autoridades incentivavam a sua ocupação como atesta o morador A, ex-garimpeiro (entrevista em mar./2013)

Fulano, que era o prefeito lá de Alto Paraíso, veio comigo nos garimpo. Chegou lá e falou assim: "vocês gostam muito de garimpo, vocês aposseam essa terra aqui (Silêncio, Segredo, os nomes atuais das localidades). Isso aqui, desde meus avós, que eu nunca ouvi falar que fosse de alguém, é terra devoluta. Mais tarde, vocês vão requerer do Estado e aí a terra é suas, não deixa ninguém entrar", e nós ficamos.

Enquanto alguns garimpeiros se apossavam das terras devolutas da região, outros trabalhavam em parceria com os proprietários já estabelecidos às margens do rio São Miguel, conforme o relato seguinte

Trabalhei de lavoura também, (plantava) arroz, feijão, mandioca, milho, batatadoce, tudo. Eu plantava de renda, eu plantava de a meia, porque a gente não tinha o terreno. Quem tinha terreno fornecia à gente, ou a gente plantava de meia ou plantava na renda. A renda às vezes acontecia, era 10 ou $20 \%$. Era o 
que garantia o sustento (morador G, ex-garimpeiro e condutor de visitantes, entrevista, mar./2013).

Em paralelo com a atividade garimpeira ou nas ocasiões em que o cristal de rocha estava com os preços em baixa no mercado, as pessoas se dedicavam à agricultura de subsistência, seja pela dificuldade econômica de se conseguir alimentos, seja como atividade complementar à da garimpagem, até mesmo na época das chuvas, quando diminuíam os trabalhos nas catas, conforme depoimento a seguir:

quando era nas águas, os garimpeiros que não faziam dinheiro para voltar, ficaram por aqui mesmo, na beira do (rio) São Miguel. Era mata, colhiam suas rocinhas. Faziam roça para ajudar o garimpo, porque aqui (os preços das mercadorias) era tudo pela hora da morte (morador B, ex-garimpeiro, entrevista, mar./2013).

Oliveira (2009) frisa bem a complementação das atividades de garimpagem com a agricultura de subsistência e registra o seu caráter diversificado para garantia do sustento das pessoas.

Ali os garimpeiros, na queda do cristal, aproveitaram o tempo enquanto voltava a aceitação de pedra dos cristais e tratavam de uma rocinha. Começaram também com uma criação de galinhas, um porquinho deles, criava uma vaquinha e, aí no tempo que voltava a influência da garimpagem, eles não se apertavam, tinham condições de romper a temporada (OLIVEIRA, 2009, p. 22).

Dessa forma, essas pessoas foram se moldando à realidade do local, criando um modo de vida peculiar que lhes permitisse a sobrevivência.

Essa população para sobreviver às crises com a venda do cristal, buscava na agricultura e na criação de animais formas de garantir a subsistência. Assim os garimpeiros criaram formas e ritmos próprios de lidar com o ambiente, associando a roça e o garimpo. [...] A retirada de palhas, lenha, frutas comestíveis e a queima da área para limpeza da macega, faziam parte das técnicas e conhecimentos que constituíam seu universo cultural (SILVA, 2003a, p. 54).

Behr (2000, p. 60) salienta que, concomitante à lida com a terra, nos momentos críticos da garimpagem, o extrativismo vegetal também se tornara outra alternativa, "a sobrevivência às diversas crises da atividade econômica do cristal era buscada na agricultura e na extração de flores secas do cerrado".

A atividade de extrativismo, de certa forma, garantia o sustento desses garimpeiros como também a prestação de serviços nas propriedades da região, como expõe o morador $D$, proprietário rural e exgarimpeiro (entrevista, mar./2013)

Aqui a gente plantava milho e feijão, só pro gasto. [...] quando não era garimpo, a gente pegava empreitada de pasto dos outros prá limpar. 
A gente apanhava aquela flor, a palipalã, pirec. Era só prá manter mesmo, quando você tirava a flor, às vezes a gente vendia pro cara que era dono de um boteco (venda) em Alto Paraíso. Então a gente já pegava a despesa com ele, praticamente era prá pagar a despesa.

Nesse depoimento verifica-se uma relação de troca com um comerciante, em que não envolvia pagamento monetário, pelas despesas realizadas (gastos com mantimentos em geral), característica de um escambo. No caso também pode se observar uma relação de dependência a um agente que exercia o papel de intermediário no processo de aquisição do material.

Assim, muitas pessoas que para a região se deslocaram em busca da garimpagem foram se estabelecendo no trecho do rio Preto ao rio Tocantins, como Oliveira (2009, p. 67) apontou, "muitos viam os blefados melhorar de situação com a lavoura, as terras do estado, ou devoluta, não era proibido fazer uma rocinha". Segundo o morador B, ex-garimpeiro (entrevista, mar./2013), blefar no garimpo significava a pessoa "não arranjar nada" na atividade e ficar sem possibilidades de retornar para o local de origem ou até mesmo de não conseguir recursos suficientes para sobreviver, visto que essas pessoas vivam de garimpo em garimpo, à procura de riqueza.

Novaes (2002, p.53) afirma que o garimpeiro "quando decide abandonar o nomadismo guiado pelas notícias das pedras e metais preciosos não tem dificuldades em adaptar-se ao estilo de vida ditado pela agricultura de subsistência".

Com relação à atividade da garimpagem, era uma operação exclusivamente manual, uma atividade praticamente artesanal (SEABRA, 1998). Como ferramentas, como relataram os ex-garimpeiros do Distrito (entrevistas em mar./2013), utilizava-se picaretas, marretas, pás, chibancas, ponteiros e cunhas, adquiridas na maioria das vezes em Formosa-GO. Também se usava a dinamite para explodir a rocha e encontrar o veio de cristal.

Algumas pessoas trabalhavam por conta própria, com suas ferramentas, mas uma outra grande parte mantinha uma relação de trabalho, um contrato precário, com alguns fornecedores, cuja situação era denominada de "meia-praça" com as seguintes características, conforme relatos de ex-garimpeiros:

A pessoa aceita as despesas e a ferramenta, e aquilo ali, o que fizer, $50 \%$ é do fornecedor e $50 \%$ do garimpeiro. Tinha muito disso, quase tudo era meia praça (morador B, ex-garimpeiro, entrevista, mar./2013).

O patrão entra com as ferramentas, as coisas e a comida, e ele tem direito em $50 \%$ e o patrão em $50 \%$, é uma sociedade (morador A, ex-garimpeiro, entrevista, mar./2013).

Se você tem um garimpo, você não tem dinheiro para me pagar, aí vou trabalho com você de sociedade. $O$ que vou arrancar, metade é seu, metade é meu. Você 
entra com as despesas, eu entro com o serviço (morador E, ex-garimpeiro, excomprador de cristal, entrevista, mar./2013).

O material encontrado pelos garimpeiros era comercializado com diversos tipos de compradores, de acordo com as menções dos ex-garimpeiros ouvidos (entrevistas mar./2013), eram representantes de empresas de exportação, compradores intermediários maiores que se deslocavam até a localidade e compradores menores, locais, também denominados de "faisqueiros" que moravam em São Jorge ou em Alto Paraíso. Alguns eram provenientes de Cristalina-GO, outros do Rio de Janeiro, São Paulo, entre outras cidades. Segundo um ex-garimpeiro (entrevista mar./2013), que depois de certo tempo de trabalho, passou a ser representante de uma empresa compradora do Rio de Janeiro, existiam cerca de 10 ou 12 compradores na região. O destino do cristal, muitos garimpeiros não sabiam ao certo, só que era exportado.

Novaes $(2002$, p. 53) revela como se davam as transações nesse incipiente mercado, "cujas relações de troca nos surtos de maior atividade se davam predominantemente com Formosa e Cristalina, mais ao Sul, de onde os compradores do cristal intermediavam gêneros alimentícios".

O preço recebido pelo material também não compensava em muito a atividade, principalmente nas épocas em que a demanda pelo produto baixava no mercado internacional, conforme destaca o morador A, ex-garimpeiro (entrevista, mar./2013), "pelo trabalho que o garimpeiro tem, eles pagavam barato demais, hoje o cristal tem mais valor do que naquele tempo".

O cristal de rocha tinha sua valorização no mercado em função de sua utilização, coincidindo sua maior procura por ocasião da 2ª Guerra Mundial, durante os anos de 1940, e na época da Guerra da Coreia, nos anos de 1950, como frisa Behr (2000, p. 60),

o ciclo do cristal durou até a década de 1960 (auge em 1941). Naquela década os poderes curativos do quartzo ficaram menos interessantes do que seus poderes elétricos para uso em telecomunicações em minas de defesa, e o quartzo passou a ser produzido artificialmente pelas indústrias.

Desse período em diante, só tinha demanda de mercado as pedras maiores, aquelas menores, denominadas lascas, eram comercializadas com compradores locais, que as destinavam para Cristalina-GO, polo produtor de artigos com pedras, como bijuterias, com pagamentos à base de troca por mercadorias, como relata a moradora F, ex-garimpeira, proprietária de estabelecimento (entrevista, mar./2013) que vivenciou essa fase:

Eu já vivi a época da lasca, que você pegava no garimpo assim por cima a lasca. Era aquilo que eles (garimpeiros) não queriam, numa época aonde só tinha valor aquelas pedras maiores, a gente ia e pegava, catando por cima. Fazia isso para ajudar em casa, na compra de comida, essas coisas. 
Oliveira (2009, p. 30) descreve o final do ciclo do cristal em que os compradores de pedras deixaram a atividade, ficando somente os compradores de lascas que se mantiveram na localidade, no final dos anos de 1960, mostrando o declínio da garimpagem, "compravam a lasca trocando em mercadoria [...] para não deixarem os garimpeiros passar fome e o garimpo ir embora".

Até então, a presença do Estado na região era nula e todo o movimento da atividade de garimpagem era feito sem fiscalização e sem o controle de agentes de governo. Algum tipo de intervenção em termos de arrecadação fiscal se dava a partir de Formosa-GO, onde os compradores declaravam a mercadoria, emitiam notas para a sua circulação, conforme os relatos do morador $B$, ex-garimpeiro (entrevista, mar./2013) "tinha que tirar a guia em Formosa, para poder seguir prá frente", e do morador E, ex-garimpeiro, que se tornou também comprador (entrevista, mar./2013), "imposto só na coletoria, que você não viajava sem a mercadoria guiada".

A garimpagem consistia de uma atividade que causava muito impacto na região e a visão das pessoas que dela se ocupavam era de ganho próprio e exclusivo, como frisou um ex-garimpeiro (entrevista, mar./2013), "o trabalho no garimpo era cada um prá si". Lima $(1998$, p. 55) retrata bem essa situação de vida de uma pessoa que exerce essa atividade ao expor: "para os garimpeiros, os cristais representam uma solução instrumental e economicista, fundada em uma ética individualista, pela qual cada um busca com suas próprias forças a possibilidade de fazer riqueza".

Não existia uma preocupação com a questão ambiental, como se pode observar no que relata um dos moradores mais antigos da localidade, acerca da garimpagem e da sua interrupção, com a chegada do "pessoal do MA", à época, que marcou a fundação do Parque Nacional:

Aquilo acontecia que ficava era um roçado danado, o que o garimpeiro não der fim, só Jesus Cristo. A destruição vai arrancando é tudo. (Se não chegasse o pessoal do MA) tinha arrasado com tudo. Foi quando o IBAMA ${ }^{3}$ chegou, chegou e foi barrando tudo, foi em 1962 (morador B, ex-garimpeiro, entrevista, mar./2013).

As marcas dessa época ainda estão na paisagem e não podem e nem devem ficar esquecidas, agregando um valor na abordagem histórico-cultural, transformadas em atrativos turístico-educativos numa das trilhas do Parque Nacional: "não se pode deixar de ressaltar a existência, no PNCV, no Morro do Garimpão, dos sinais da antiga atividade predominante na região, as catas deixadas pelos garimpeiros" (DOMICIANO e OLIVEIRA, 2012, p. 193). 
Nota-se que os valores dominantes eram aqueles que se fundavam no âmbito econômico e na própria sobrevivência das pessoas, até a localidade ser designada, por suas características já mencionadas, para ser abrigo de uma Unidade de Conservação.

\subsection{A CRIAÇÃO DO PARQUE NACIONAL DA CHAPADA DOS VEADEIROS}

Na década de 1960, já com o desenrolar da Marcha para o Oeste, com o intuito de ocupar os vazios demográficos dos territórios do Brasil Central, cujo ícone maior foi a construção de Brasília, ocorreu a criação do atual Parque Nacional da Chapada dos Veadeiros. Segundo Albuquerque (1998), o modelo desenvolvimentista que impulsionou a transferência da capital federal passou a ditar o ritmo dos processos que construiriam o cenário da ecorregião dos cerrados, interferindo em seus aspectos sociais, econômicos, tecnológicos e ambientais.

Seabra (1998, p. 89) corrobora essa linha de pensamento ao afirmar que, "historicamente, é o avanço das frentes pioneiras de desenvolvimento que têm exigido a implantação das áreas de proteção ambiental e contraditoriamente, esse mesmo desenvolvimento ameaça a integridade das unidades de conservação já estabelecidas".

Com a transferência da capital federal para o planalto central do país, deu-se a criação de várias unidades de conservação nesta área, inclusive uma no próprio Distrito Federal (Parque Nacional de Brasília) e mais duas, nas regiões dos rios Tocantins (Parque Nacional do Tocantins - atual PNCV) e Araguaia (Parque Nacional das Emas).

Para Oliveira (2007, p. 40), “a implantação do PNCV deve ser entendida, também dentro do contexto da criação de Brasília", para atender as necessidades da população das pessoas da cidade, conforme destaca Drumond (1997) citado por Behr (2000, p. 91)

\footnotetext{
uma vez decidida a mudança da Capital Nacional para Brasília, em 1956, foram criados em 1959 e 1961, os primeiros três parques nacionais definitivamente "sertanejos" (Araguaia, Emas e Chapada dos Veadeiros). Os seus documentos de criação enfatizam o seu papel de oferecer lazer aos futuros habitantes da nova capital nacional.
}

O Parque Nacional foi criado para atender uma proposta da Fundação Brasil Central, instituído sob o Decreto Presidencial de $n^{\circ}$ 49875, de 11 de janeiro de 1961, assinado pelo presidente Juscelino Kubitschek, com o nome oficial de Parque Nacional do Tocantins, com 625.000 ha (BEHR, 2000; MARTINS, 2011). 
Segundo Silva (2003b, p. 71), ao ser criado, houve a "institucionalização da paisagem", num confronto de olhares das pessoas do lugar com os que viriam a usufruir das suas belezas cênicas: "De um lado, um olhar derivado de uma imersão no ambiente por aqueles que ali vivem. De outro, a visão fugaz de quem está de passagem em busca da diversidade de imagens". Esse embate de visões permite a compreensão dessa paisagem com sua "complexidade multiforme de realidades, valores, sentimentos e significados", assegura ainda a autora.

O ato de criação do Parque Nacional, com suas dimensões iniciais, causou uma reação numa parte da sociedade local da Chapada, que perdeu suas terras ou teve que cedê-las para a formação da UC, alegando que o Parque seria um motivo de perdas para a economia da região. A saída encontrada foi a redução de sua área, por parte da instância que o criou, conforme atesta Behr (2000, p. 91)

Após sua criação, em 1961, os antigos proprietários da área do Parque Nacional continuaram a explorar suas terras, embora dentro dos limites do decreto de criação, obrigando o órgão responsável pela administração e jurisdição dos parques nacionais da época, o Instituto Brasileiro de Desenvolvimento Florestal - IBDF, a propor uma drástica redução em sua área, pois seus novos limites não chegavam mais ao rio Tocantins. Forte pressão política e a não indenização dos proprietários foram as causas principais dessa mutilação.

Pelo Decreto $\mathrm{n}^{\circ}$ 70492, de 11 de maio de 1972, do presidente Emílio Garrastazu Médici, a área do Parque foi reduzida para 171.924 ha e sua denominação passou para Parque Nacional da Chapada dos Veadeiros (BEHR, 2000; MARTINS, 2011).

Houve outra redução de área do Parque em 1981, por força do Decreto $n^{\circ} 86173$, de 2 de julho, retificado pelo Decreto $n^{\circ} 86596$, de 17 novembro, do presidente João Batista Figueiredo, para 60.000 ha, em atendimento ao Projeto Alto Paraíso, que propunha a exclusão de uma área degradada, para a implantação de projetos agropecuários e industriais, na região de Alto Paraíso (BEHR, 2000; MARTINS, 2011).

Em 1990, o IBAMA, procedeu uma anexação de terras, declarando-as de utilidade pública e a área do Parque Nacional, regulamentada pelo Decreto $n^{\circ}$ 99279, de 2 de junho, do presidente Fernando Collor de Melo, passou para os atuais 65.514,7259 ha, incluindo aí a margem esquerda do rio Preto, do Cânion I ao poço do Salto II, até o topo do morro do Garimpão (BRASIL, 2009; MARTINS, 2011), que viria a se constituir parte das trilhas abertas ao público para a prática turística.

Ainda, em 2001, uma alteração da área do Parque Nacional foi implementada, pelo Decreto s/n, de 27 de setembro, do presidente Fernando Henrique Cardoso, aumentando sua área para cerca de 235.000 ha, com o intuito de obter o título de Sítio do Patrimônio Natural Mundial, concedido pela Organização 
das Nações Unidas para a Educação, a Ciência e a Cultura (UNESCO). Porém, em 2003, esse decreto foi derrubado por força de um mandato de segurança do Superior Tribunal Federal, reduzindo aos 65.514,7259 ha, delimitados anteriormente (BRASIL, 2009).

Essa variação na área do PNCV (Anexo B) reflete a questão da política de regulamentação das terras no Brasil, principalmente as consideradas devolutas, não somente aquelas terras que fazem parte do Parque propriamente, mas também as que compõem o conjunto das propriedades no seu entorno. A questão do regime de propriedade de terras, em especial nas regiões de cerrado, segundo Mazzetto Silva (2009, p.101), seguiu um expediente corriqueiro no qual se observou que parte das terras devolutas foram apropriadas de formas "muitas vezes obscuras: grilagens, concessões pouco transparentes dos órgãos de terra dos estados que não visavam ao bem comum e à gestão pública dessas áreas, muito menos as suas funções sociais e ecológicas".

A esse respeito, Bezerra da Silva (1998, p. 205) esclarece que "o regime fundiário dominante em Alto Paraíso é a posse de terras, que, geralmente, não possuem título de propriedade, salvo para os grandes fazendeiros. Assim, aos pequenos produtores cabe a propriedade da casa, mas não a propriedade da terra".

O depoimento de um agente da AGRODEFESA mostra essa situação, quando trata da precariedade da posse da terra, com o agravante das medidas serem tomadas com a finalidade de estabelecer uma área destinada à conservação.

Já houve casos de pessoas que não foram indenizadas, justamente porque não tinha o título da propriedade. É muito precária a titularidade, a posse da terra. Às vezes se faz a desapropriação, se paga a benfeitoria e pede para a pessoa, a família desocupar o terreno. Essa estratégia de preservação ambiental, para mim, ela é totalmente equivocada e se baseia em um mito, que se chama o mito moderno da natureza intocada (agente da AGRODEFESA, entrevista, jul./2013).

Segundo o Agente Administrativo B do ICMBio (entrevista, jul./2013), já existiu muito conflito no passado envolvendo a posse da terra, e questionado sobre as desapropriações, o mesmo afirmou:

Muitas terras são devolutas. Como os cartórios da região fraudaram muito os títulos, houve casos de 15 matrículas da mesma terra. O ICMBio já indenizou parte dos proprietários antigos, porém há muitos processos de indenização abertos na justiça.

São questões tanto de natureza política, como já mencionado por Behr (2000), quanto também aquelas relacionadas à regularização fundiária na região, um processo burocrático e moroso, por envolver instâncias judiciais e a inexistência de recursos orçamentários para a indenização ou aquisição, e até mesmo a dificuldade de identificar a titulação dessas terras (BRASIL, 2009). Conforme 
Bezerra da Silva (1998), o Instituto de Desenvolvimento Agrário de Goiás (IDAGO) moveu uma ação discriminatória para demarcação definitiva e concessão de títulos de propriedade definitiva no município. Essa questão pode ser elucidada com o relato do Agente A da Administração do Município de Alto Paraíso de Goiás (entrevista, jul./2013):

O Parque Nacional tem a parte dele para ser resolvida, a dificuldade é exatamente isso, eram terras devolutas, as pessoas que estavam na posse da terra há anos, há décadas, não tiveram direito nenhum [...] alguns outros tem pendências judiciais que estão sendo resolvidas.

A realidade da região nossa é que agora o governo federal deu andamento para se resolver a nossa (ação) demarcatória, a (ação) discriminatória já foi feita, transitado em julgado, o que é particular, o que é terra devoluta. Mas nós precisamos agora fazer a demarcação dessas terras que são particulares, para ter seus documentos específicos, e depois, ser tratadas as terras devolutas, das posses que existem, como vai ser tratada a realidade desse pessoal.

A ocupação das terras foi um elemento que acirrou as tensões entre os moradores locais e a UC. Como afirma Saraiva (2012, p. 210), "a presença do Parque acentuou conflitos, entre eles os que dizem respeito ao território tradicionalmente ocupado pela população nativa". Foi necessária a desocupação da área para a instalação do PNCV, gerando desapropriações de terras de pessoas aí estabelecidas há muito tempo, em consonância ao relato anterior

Essa desapropriação atingiu, indistintamente, fazendeiros, lavradores e garimpeiros. Cada um desses grupos experimentou de forma diferente a experiência de ver suas terras, roças e lugares, ocupados por várias gerações, terem que ser desocupadas em nome da preservação da natureza (SARAIVA, 2012, p. 210).

Segundo a autora, seguindo a linha de pensamento de Diegues (2001), a visão preservacionista do mito da natureza intocada predominara, não só na implantação dessa UC, como também em outras Brasil afora, como também advertiu Seabra (1998), em estudo realizado na Chapada Diamantina-BA.

Para Albuquerque (1998), a história da implantação do Parque Nacional explicita o panorama do desenvolvimento moderno da Chapada dos Veadeiros. Conforme o autor, nos anos de 1970, com a implementação do III Plano Nacional de Desenvolvimento (PND), a Chapada dos Veadeiros e, especificamente, o município de Alto Paraíso de Goiás, por meio do Programa de Desenvolvimento Integrado de Alto Paraíso (PRODIAP), tiveram identificadas as suas vocações econômicas para alavancar o desenvolvimento regional. Tais planos apontaram a agricultura e o turismo como indutores desse desenvolvimento, devido as suas características locais.

De acordo com o autor, para grande parte da Chapada recomendou-se a agricultura intensiva da soja, enquanto que, para a região do Parque Nacional: “A área de produção de soja diminui conforme se 
aproxima da área nuclear, onde se encontra o Parque" (ALBUQUERQUE, 1998, p. 250). O mesmo ressalta que características como a declividade do terreno e do solo, pouco profundo e propenso à lixiviação, tornavam a localidade imprópria para a cultura.

Novaes (2002) frisa também o fato da "inaptidão natural das terras" do município para o tipo de agricultura que era estimulado pelas políticas governamentais da época e acrescenta ainda, no tocante à topografia e as condições do solo da região que: "o relevo movimentado e os solos rasos e quartzosos impedem a mecanização e a produção de grãos em larga escala" (NOVAES, 2002, p. 30).

As áreas agricultáveis são restritas, localizam-se na parte sul do município, no limite com o município de São João da Aliança e na região leste, acompanhando o rio São Bartolomeu, conforme atesta o Agente A da Administração Municipal (entrevista, jul./2013)

Menos de $10 \%$ da área do município é utilizada para agricultura e pecuária [...] grande parte de nossa área é área de preservação permanente, por conta da altitude [...] o nosso terreno não é um terreno adequado para a agricultura.

A maior marca que a gente fala que aqui não tem vocação agrícola é que os gaúchos chegaram até aqui, tentaram produzir, não deram conta e foram embora.

Silva (2003a) destaca que na proposta da criação do PNCV, existia uma preocupação com as características ímpares da região e sua beleza cênica. A demora em regularizar a situação da área, resolvendo a questão relativa à terra, e o descaso com os moradores locais, principalmente da Vila de São Jorge, à época, mostravam a despreocupação com os aspectos socioculturais da região. Existia até sugestão de retirada dos moradores da vila, do local onde estavam instalados, porém, "o que se verificou posteriormente foi que, em função das pressões dos fazendeiros locais, o Parque foi encolhido, recebendo nova denominação, e a Vila de São Jorge ficou fora dos limites do atual Parque Nacional da Chapada dos Veadeiros" (SILVA, 2003a, p. 44).

Com a criação do PNCV houve uma alteração dos modos de vida das pessoas da região, principalmente dos primeiros moradores da Vila de São Jorge e arredores:

\footnotetext{
"foi um fato que marcou indelevelmente o destino funcional da Chapada dos Veadeiros. De um lado reconheceu-se a excepcionalidade geográfica da região. De outro causou imediato desconforto econômico e social para a população local (...) porque furtava o suporte de sua atividade produtiva, a posse da terra e a exploração dos recursos naturais" (ALBUQUERQUE, 1998, p. 244).
}

Essa afirmativa pode ser corroborada pelos depoimentos dos proprietários sobre o seu fazer na lida com a terra: 
Nós plantava tudo pra sobreviver, plantava o arroz, feijão, milho, mandioca, tudo de lavoura nós plantava. (Hoje) criaram uma norma aqui em torno do Parque, que a gente não pode cultivar nada aqui (proprietário rural $\mathrm{A}$, exgarimpeiro, entrevista, mar./2013).

Só que daí, com a criação do turismo, o efetivo de guardas (fiscais) no Parque aumentou, daí proibiu geral de trabalhar tanto a lavoura quanto o garimpo. Até a criação de gado foi meio que restringido também, porque não dava pra fazer a pastagem, quem tinha a pastagem pronta, continuou. E não dava mais pra desmatar e fazer a pastagem, porque a gente mora na zona de amortecimento do Parque, daí prá você fazer qualquer coisa tem que ser com licença ambiental, tem que vir o técnico vistoriar, aí complicou mais (proprietário rural B, condutor de visitantes, entrevista, mar./2013).

A partir desses relatos pode-se observar o modelo de conservação adotado para a UC, não se levando em consideração as práticas das pessoas ali residentes e que as mesmas já conviviam com aquele ambiente, mantendo com ele certo equilíbrio, garantindo a sua sobrevivência, nos moldes aprendidos e herdados de seus antepassados. Conforme apontou Silva (2003a, p. 45), não se levou em conta que “mesmo em áreas protegidas, a diversidade ecológica deve caminhar pari passu com a diversidade cultural e que uma depende da outra".

Para Saraiva (2012), essa população mantinha suas atividades naquele ambiente e aquele mundo não era intocado, existia uma relação homem-natureza:

o cerrado foi conservado em meio a práticas culturais como a caça, a criação do gado, o garimpo e a coleta de flores tão presentes nas histórias de vida desse grupo. A natureza, para as populações tradicionais, é representada como um bem a ser explorado para atender suas necessidades vitais, mas também como um bem a ser protegido (SARAIVA, 2012, p. 222).

Mesmo com o uso para as atividades cotidianas, essas comunidades pouco impactaram o ambiente onde viviam. Conforme Mazzetto Silva (2009, p.99), análises de imagens de satélite mostram essas áreas pouco tocadas, levando a crer que "boa parte desses usos tradicionais consegue manter as fisionomias de cerrado nas chapadas bastante próximas do que poderíamos chamar de cerrado nativo".

A chegada do Estado na localidade, por intermédio das instituições que administravam o Parque Nacional, primeiramente o IBDF e depois o IBAMA, manteve certa distância dos moradores locais, não procurando uma aproximação das pessoas para conhecer a realidade da região. $O$ depoimento a seguir mostra bem a relação inicial e a visão que tinham os administradores do PARNA em relação às pessoas do local, conforme destaca o morador C (entrevista mar./2013): 
Olha, o IBAMA amedrontou muito a gente, porque era como um xerife. 0 primeiro diretor que veio aqui, que foi o Dr. Beltrano, eu chamei ele um dia e falei com ele: Dr. o senhor podia chamar os nativos e se informar deles o que é isso aqui e como pode ser feito. "Esse povo não sabe de nada" (foi a resposta dada pelo administrador ao morador).

Essa situação perdurou por mais de duas décadas, num clima de animosidades e distanciamento entre administradores e comunidade local, em que os moradores tentaram contornar a situação, ao buscar formas alternativas de sobrevivência, como relata a moradora $F$, ex-garimpeira, proprietária de estabelecimento (entrevista, mar./2013)

A Vila de São Jorge foi uma comunidade que sofreu muito. Primeiro quando deixou de ser o garimpo de cristal, onde as pessoas, todo mundo que aqui morava, tirava o seu sustento, lá do garimpo. Aí virou o Parque Nacional e começou uma história, uma guerra de amor e ódio. Chegou um momento em que eles (garimpeiros) não podiam trabalhar mesmo, de qualquer maneira.

O distanciamento da administração do Parque Nacional da comunidade ainda refletia o contexto de uma linha de visão preservacionista no país, do início do século $X X$, de resguardar somente as paisagens naturais de grande valor estético, não levando em consideração a presença das pessoas nas UC e suas imediações. Depois, nos anos de 1970, o objetivo maior era a proteção das espécies ameaçadas de extinção, e também não havia uma preocupação com as pessoas dessas localidades (SEABRA, 1998).

Em 1982, no $3^{\circ}$ Congresso Mundial de Parques Nacionais, realizado em Bali (Indonésia), essa visão da preservação ganhou outros contornos, estabelecendo-se que a conservação da biodiversidade não poderia ocorrer isoladamente. Foi sugerido na Declaração de Bali que os governos dos países tomassem medidas de desenvolvimento social e econômico sustentado, dentre elas a que "o manejo das áreas protegidas deveria ser realizado em conjunto pelas autoridades administradoras das unidades de conservação e as comunidades tradicionais" (SEABRA, 1998, p. 100).

Coincidente com esse período, nos anos de 1980, o turismo começa a ganhar força no Parque Nacional, ainda sem controle, permitindo-se até mesmo o acampamento das pessoas no interior da unidade, como afirmou o morador L, ex-garimpeiro e condutor de visitantes (entrevista, mar./2013), referindo-se ao que foi encontrado no Parque quando houve uma interrupção da visitação pelo seu uso desregrado:

Porque naquela época, em (19)91, nós tiramos várias toneladas de lixo de dentro do Parque Nacional, quando o pessoal entrava e acampava dentro do Parque. Todo o lixo produzido era deixado lá dentro. [...] O que não jogava dentro do rio, eles deixavam lá. 
A atividade turística ganhou força na região, em função da implementação de um plano de desenvolvimento do governo do estado de Goiás, denominado Projeto Alto Paraíso. Por esse projeto, a partir de 1979, deu-se início à instalação de alguns equipamentos urbanos que contribuíram para a atividade turística na região, entre eles a construção de uma pista de pouso no município, a abertura da estrada GO-239, que atualmente liga a Colinas do Sul, facilitando o acesso ao PNCV (BRASIL, 2009).

Outro elemento de fundamental importância para a atividade turística na região foi o asfaltamento da estrada GO-118, que liga o Distrito Federal a Alto Paraíso de Goiás, em 1986, facilitando o deslocamento de pessoas até a localidade, e a partir de então, "iniciou-se um movimento de especialização funcional do município como estância turística, particularmente de Brasília, que se estendeu e se amplificou nos anos de 1990. Uma multidão crescente de turistas passou a visitar todos os anos o Parque Nacional e seu entorno" (ALBUQUERQUE, 1998, p. 250).

Na década de 1990, a política de diminuição do aparato do Estado restringiu a ação dos órgãos ligados à conservação ambiental no país, momento em que surgiram as organizações da sociedade (ONG), voltadas para a área ambiental. Essas atividades, com suas propostas de uso sustentável dos recursos naturais, atuariam em parcerias com o governo federal na co-gestão das UC (SEABRA, 1998), desenvolvendo projetos com as comunidades do seu entorno.

O Parque Nacional direcionou, então, as atividades da região para o turismo, mais especificamente o ecoturismo. A atividade turística, que se iniciou em ritmo lento, ganhou força a partir da década de 1990 e atingiu os contornos atuais. Mas a população da Vila ainda estava às voltas com as questões que envolviam a instalação do Parque e dos desdobramentos que desse fato vieram, as impossibilidades de tocarem normalmente suas vidas como antes e tinham certo receio frente a essa nova atividade.

Quando chegou o momento do turismo, de novo parece que a história ia se repetir, onde a comunidade ia ficar à parte, porque era um novo momento. Era um novo modelo de busca da sustentabilidade, mudança da economia, mas a comunidade não se encaixava nesse novo modelo, porque ela não estava pronta prá isso, era uma coisa muito nova. E além de ser muito nova, não tinha recurso financeiro, não tinha nada para poder estar entrando também nesse mundo novo do turismo (moradora F, ex-garimpeira, proprietária de estabelecimento, entrevista, mar./2013).

O turismo aqui foi uma coisa inesperada, ela veio como um trator, as pessoas estavam despreparadas. De repente chegou, foi um choque, um choque em tudo, na cultura, no sistema de vida. Foi um choque, as pessoas ficaram meio extasiadas, mas depois foi se aclimatando e deu tudo certo (morador C, entrevista, mar./2013). 
O desenvolvimento do ecoturismo praticado no PNCV e com a intervenção do IBAMA ${ }^{4}$, que estabelecia dentre as suas normas a obrigatoriedade de condutores de visitantes no interior do Parque, propiciou que os ex-garimpeiros tomassem parte nessa atividade. Também se iniciou um processo de inserção da população local nessa atividade turística, abrindo espaço para os moradores atuarem no setor, nas áreas de hospedagem, alimentação e comércio, principalmente. Como salientaram Brandão e Barreto (2009, p.362), com esse processo "buscou-se parcerias entre a população e gestores do Parque, motivo pelo qual se considera que o ecoturismo trazido pelo Parque tem sido elemento de conciliação e transformação da relação com a comunidade".

A comunidade organizou-se em torno de associações para a resolução de seus problemas. Foi por intermédio da organização da população que benefícios como a captação e distribuição de água, energia elétrica, serviços de saúde e educação começaram a chegar ao Distrito. A primeira associação foi fundada em 1986, a Comissão Pró-Melhoramento de São Jorge (CPMSJ), em cuja ata de fundação constavam as prioridades da comunidade, como água, luz (energia), registro de terrenos e assistência médica, conforme relata um morador:

Essa associação, sabíamos que teria que ter uma administração aqui de alguma coisa e fomos. Não tinha água, a nossa água aqui era de um corguinho que desce aí (Ribeirão Rodoviarinha), aquele tiquinho de água lá. E nós fizemos a associação. E lá (o chefe do PNCV) tinha feito uma barragem prá trazer água prá ele. Sobrava muita água, então nós fizemos um documento e conseguimos a sobra daquela água (morador C, entrevista, mar./2013).

Outro morador detalha as ações da associação e reforça a sua importância na consecução das melhorias para o Distrito.

\footnotetext{
Através da associação nós conseguimos comprar a encanação todinha, sete quilômetros (de cano) para instalar a água, e conseguimos também, no IBAMA, em Goiânia, a doação da barragem.

Nós conseguimos posto de saúde, conseguimos escola, conseguimos energia e conseguimos água (morador E, ex-garimpeiro, ex-comprador de cristal, entrevista, mar./2013).
}

A Associação de Moradores da Vila de São Jorge (ASJOR) foi fundada em 1988, já no limiar da década de 1990, quando o ecoturismo se firmou como atividade principal na região, no PNCV e também nas propriedades particulares, com seus atrativos no entorno. Existia uma preocupação com o desenvolvimento socioeconômico, sem perder de vista a questão da sustentabilidade, preconizado pelo Projeto Veadeiros ${ }^{5}$, segundo explanou a moradora F, ex-garimpeira, proprietária de estabelecimento e também ex-dirigente da associação (entrevista, mar./2013): 
Presidi a associação por muito tempo, onde nós trabalhamos um projeto com propostas de desenvolvimento sustentável, uma proposta voltada para o turismo de base comunitária com a sustentabilidade. Essa fase foi onde aconteceu muita coisa, a gente se organizou, foi bem interessante, em meados da década de [19] 90. Era muito forte essa questão da organização social aqui em São Jorge.

Essa organização dos moradores na região seguiu uma trajetória de mudanças socioeconômicas e culturais ocorridas na Chapada dos Veadeiros, em função da integração com grupos de pessoas migrantes de outras regiões do país, que buscavam "formas alternativas de vida e de relacionamento com a biodiversidade" com propostas de sustentabilidade, em que visavam "democratizar os espaços políticos, econômicos, sociais e culturais", propiciando o desenvolvimento de "uma consciência sócioecológica" (BEZERRA DA SILVA, 1998, p.209).

Em 1991, numa iniciativa do IBAMA, foi promovido um treinamento das pessoas da comunidade, principalmente aquelas que se ocupavam da atividade garimpeira, para se tornarem condutores de visitantes, uma vez que a partir daquele momento estava proibida a entrada de visitantes no Parque Nacional sem o acompanhamento de um condutor de visitantes local, mediante o pagamento de uma taxa. Foi uma das formas que o órgão encontrou para que parte dos gastos realizados pelos visitantes fosse revertida em alguma forma de renda para a população local, conforme afirmaram os moradores abaixo acerca desse processo:

Foi um curso mais técnico para treinar as pessoas para receber o turista, prá saber lidar com o turista, porque ninguém, no momento, não sabia como tratar, como receber, recepcionar (morador $\mathrm{H}$, ex-garimpeiro, condutor de visitantes e presidente da ACVCV entrevista, mar./2013).

Veio um cara prá cá, um chefe de Parque, Dr. Sicrano., foi ele que ajudou a criar a associação. Chegou aqui, entende, como a pressão era muito grande pro pessoal ir na cachoeira e ninguém podia ir, porque na verdade foi proibida essa visitação por causa da depredação e a poluição [...] Aí ele teve essa ideia de pegar os garimpeiros, que era o povo que ocupava o Parque e trocar o serviço de garimpeiro pelo serviço de guia (morador L, ex-garimpeiro e condutor de visitantes, entrevista, mar./2013).

Os ex-garimpeiros passaram a exercer a atividade de condução de visitantes, e fundaram a Associação dos Condutores de Visitantes da Chapada dos Veadeiros (ACVCV), que de acordo com seu presidente, conta hoje com mais de cem condutores cadastrados, sendo que destes cerca de 75 estão na função e aptos a prestar o serviço de condução de visitantes. Ainda segundo o mesmo, outras associações da região (como de Alto Paraíso de Goiás e Teresina de Goiás), com cerca de 120 condutores, prestam serviços no Parque e seu entorno.

Nesse contexto, de uma nova realidade instalada na região por intermédio da atividade turística, com o arrefecimento da tutela do Estado, em função das contingências econômicas e políticas, entram no 
cenário as ONG, e em 1994, numa parceria que envolveu o IBAMA, a WWF, a FUNATURA, com apoio da UFG e da Cruz Vermelha, foi dado outro curso para os condutores que já haviam passado pelo primeiro treinamento, para melhor capacitação dos condutores de visitantes, relatou o morador $\mathrm{H}$, ex-garimpeiro, condutor de visitantes e presidente da ACVCV (entrevista, mar./2013).

Essa parceria foi relevante no processo de aproximação do Parque Nacional e a comunidade local, contribuindo para o processo administrativo da UC, e conservação ambiental na região (RIBEMBOIM, 2004). Para a população local tornou-se uma importante fonte de renda, e para os turistas, propiciou uma maior segurança na visita aos atrativos, não só do Parque, como também do entorno (BEHR, 2000).

Além da prestação de serviço na condução dos visitantes, os ex-garimpeiros foram os responsáveis, primeiramente, pelas operações de demarcação dos limites do Parque e na intermediação com as pessoas da localidade que ultrapassavam esses limites e adentravam nas terras que viriam a ser a área de conservação, em virtude da escassez de servidores que o órgão administrador tinha à época, como explica o morador L, ex-garimpeiro, condutor de visitantes (entrevista, mar./2013).

Na verdade, quando a gente começou a trabalhar nesse Parque, o IBAMA tinha pouco funcionário e a pressão era tão grande, aqui do povo. A gente como guarda do Parque, na beira da cerca prá vigiar o povo, para não entrar prá dentro para não fazer vandalismo. A gente trabalhava junto com o diretor do Parque, com mais dois fiscais que tinha. No começo a gente dava todo suporte pro Parque.

O primeiro trabalho foi, limitar, fazer o limite do Parque, tanto é que alguns lugares de visita do Parque, só quem sabe é quem trabalhou na medição.

E acrescenta que, até a época da pesquisa de campo em março de 2013, o serviço de manutenção das trilhas era realizado voluntariamente pelos condutores da ACVCV, nas segundas-feiras, na época de baixa temporada, quando não tinha visitação no Parque.

Em relação ao quesito renda, a atividade de condução de visitantes tornou-se um elemento primordial para a garantia de sobrevivência daqueles que passaram a ocupar essa função. De acordo com depoimentos dos condutores, os seus rendimentos variavam de aproximadamente um salário mínimo (à época desta entrevista, em março de 2013, o salário mínimo vigente no país era de $\mathrm{R} \$ 678,00$ ) até em torno de $\mathrm{R} \$ 2500,00$; equivalendo a 25 conduções ao mês, entre a baixa e a alta temporadas:

Se for normal, na baixa temporada, no mínimo dá 600,800 reais por mês, e (na) alta temporada, dá 2000 (reais), dois mil e tanto por mês. Dá, na média, dá pra sobreviver tranquilo, até mesmo só com guiagem (morador G, ex-garimpeiro e condutor de visitantes entrevista, mar./2013) 
Outra condutora de visitantes admitiu que a atividade já foi mais compensatória, em termos financeiros, principalmente na década de 1990, quando a região foi tomada de vez pela atividade turística. Também ponderou que, mesmo depois dessa época, a condução ainda garantia uma certa renda ao condutor de visitante

\footnotetext{
Nessa década do auge (1990), a gente não tinha baixa (temporada) [...] isso foi seis anos assim, virando sem baixa. Eu vou jogar por cima, assim uma estimativa, acredito que na época dava prá tirar uns dois salários (salário mínimo) tranquilo, por mês. Ele (condutor) não ia fazer menos que salário (mínimo) não, com certeza. Mês de julho, era praticamente 25 dias de trabalho por mês (moradora I, ex-garimpeira e condutora de visitantes, entrevista, mar./2013).
}

Além da questão econômica envolvida na atividade, mencionada anteriormente, outras nuances da atividade foram transparecendo, como a questão sócio-cultural na relação condutor-visitante. Os nativos, por sua vez, tornaram-se um elemento a mais no fenômeno de produção social do turismo ali praticado, "com sua cultura, hábitos e costumes, suas formas e suas características sociais internas, bem como seu relacionamento com os visitantes" (LEMOS, 2005, p.87), conforme se pode notar na exposição do morador G, ex-garimpeiro e condutor de visitantes (entrevista, mar./2013)

\footnotetext{
O guia é interessante não é (pela) trilha não, o guia é interessante para a caminhada que vai acontecer, contar a história de tudo que já aconteceu com ele, daquilo que vai acontecer, o que pode acontecer. Daquilo que é necessário, daquilo que não é necessário, é prá isso.
}

Nesse aspecto, observou-se, em dois momentos da pesquisa de campo com os turistas, em 2012, quando se acompanhou dois grupos nas trilhas do Parque: numa trilha, a condução foi realizada por um condutor que foi garimpeiro, e percebeu-se que o mesmo explanava com maior domínio quando mencionava as atividades realizadas na época da garimpagem, nos pontos de parada, nas catas que são atrativos nessas trilhas. Também, ao longo da caminhada, ia mostrando exemplares de espécies da flora local, indicando as suas propriedades. Em outra trilha, a condução foi realizada por um condutor mais novo, que foi mais sucinto em suas explicações sobre os assuntos abordados pelo primeiro condutor, indo mais rápido em direção aos atrativos, as cachoeiras e corredeiras do Rio Preto. A atividade turística expandiu no Parque e no entorno, nos atrativos particulares. Dessa forma, foi se criando uma estrutura para dar suporte a essa nova atividade na área de hospedagem, alimentação e comércio em geral. "Em síntese, ex-garimpeiros de cristais tornaram-se guias, donas de casa passaram a fornecer refeições, comerciantes ampliaram seus negócios e até quem dispunha unicamente de um quintal transformou-o em um pequeno camping" (BRANDÃO E BARRETO, 2009, p. 365). 
As condições que o Distrito oferecia em termos de serviços na área de turismo eram precárias nos finais dos anos de 1980. A estrada GO-239 não era asfaltada, o que dificultava o transporte de pessoas e mercadorias, não havia energia elétrica, que só foi instalada em meados de 1990, existiam duas vendas no local e as pousadas começaram a se estruturar com a chegada de pessoas de outras localidades, que viram no turismo uma nova oportunidade de negócio.

As pessoas improvisavam parte de suas residências para ofertar um tipo de serviço, por exemplo, o de restauração (alimentação), que era oferecido utilizando-se uma cozinha domiciliar e uma área externa da casa. Até a infraestrutura de apoio, como estrada para o transporte de mercadorias, e a falta de energia elétrica, eram fatores impeditivos de ampliação dos negócios, conforme expõe a moradora $F$, ex-garimpeira, proprietária de estabelecimento (entrevista, mar./2013):

Quando começou o turismo, a partir de (19)88, eu entendia que era uma proposta onde a comunidade deveria ser inserida nesse contexto. Aí, comecei a fazer comida na minha casa, eu utilizava a varanda, tinha uma mesa. Comecei a servir refeição para os visitantes que chegavam e encomendavam comida. A gente fazia uma lista de espera e eles iam chegando e a gente ia atendendo de acordo com o que tinha. Porque nessa época era muito difícil, não tinha energia elétrica, nem muita comida. Não tinha meios de transporte para buscar em Alto Paraíso, ou não tinha supermercados maiores. Então você tinha uma lista em que atendia no máximo 15 pessoas por dia. Até meados de [19]90 a gente funcionava dessa forma.

O desenvolvimento da atividade turística induziu a uma melhoria das condições de vida do local, tanto no aspecto físico, ao propiciar uma infraestrutura para as pessoas visitantes e, por conseguinte, aos moradores, quanto na forma de agir destes. Silva (2003b) afirma que a chegada de pessoas de fora imprime "novos padrões de comportamento". A vinda de novos residentes para se dedicarem à atividade contribuíram para essa mudança, como aponta o morador C (entrevista, mar./2013)

São Jorge antes do turismo não existia, existia uma vila de garimpeiros. Depois do turismo, chegou pessoas de fora e foram criando alguma coisa, dando uma visão diferente. Visão, sujeito que valorizou mais as coisas, tinha uma visão de construir as coisas prá ele.

E assim, começou a surgir uma estrutura de apoio ao turismo, com a chegada e investimento em infraestrutura de pessoas de outras localidades, o que provocou certo ceticismo aos nativos, em função das iniciativas tomadas conforme expôs o morador A, ex-garimpeiro (entrevista, mar./2013)

Aqui começou assim, sabe a Pousada Cristal da Terra, a dona dela é de Goiânia. Aí ela fez aquela pousada e o povo: "essa velha tá ficando doida", e começou a fazer chalezinho. "Essa mulher não tem juízo". Aí ela puxou o turismo prá cá, a primeira a vir foi ela. 
Em função das demandas das atividades turísticas, o Distrito de São Jorge experimentou uma transformação, para oferecer um suporte aos visitantes do Parque Nacional e que se estendeu aos seus moradores, como assegurou Hauff (2004, p. 131) "esta transformação desencadeou melhorias de qualidade nos serviços para a população e nas suas moradias, principalmente". Essa melhoria está associada a abertura do Parque Nacional e as perspectivas da nova atividade dele proveniente, garantindo a sobrevivência econômica e social das pessoas da localidade, conforme mencionou o morador A, ex-garimpeiro (entrevista, mar./2013):

Depois do Parque, pro povo guiar foi melhor, porque não podia garimpar [...] E as pousadas, os chalés, o que melhorou aqui foi isso, foi o turismo. Aqui se não fosse o turismo, isso aqui não era nada, tinha acabado.

Outro morador e condutor de visitantes aponta que com a movimentação turística na região, foi se formando uma estrutura de apoio à atividade no Distrito, em contraste com o que havia, traçando um paralelo entre os momentos pelos quais a localidade passou.

Porque aí foi onde que criou os botecos, os restaurantes, os quiosques, ai foi criando tudo. Foi em função do turismo. (Na época do) garimpo, todo mundo vivia isolado no meio do mato, só tinha duas vendas aqui, [...] quando veio o turismo todo mundo começou a colocar coisinha, construir, fazer pequenos comércios (morador L, ex-garimpeiro e condutor de visitantes, entrevista, mar./2013).

Nos últimos dez anos, dos mais de vinte mil visitantes ao ano que se destinaram ao PNCV, conforme apontado por Domiciano e Oliveira (2012, p.181), a maioria "invariavelmente, passa pelo Distrito de São Jorge que, de acordo com a administração local, possui 28 pousadas, 15 áreas de camping e residências que alugam parte de suas dependências para alojamento das pessoas".

Mas também, com o incremento no número de estabelecimentos para hospedagem, novas ocupações surgiram para os moradores, e proporcionando não somente uma fonte de renda, como uma chance de desenvolvimento no aspecto profissional, como enfatiza a moradora 0 , proprietária de uma pousada, que funciona no Distrito de São Jorge desde meados dos anos de 1990, e contava à época da pesquisa de campo com dezoito funcionários permanentes.

A oportunidade que eu vejo de um crescimento pessoal, talvez mais do que material. E a responsabilidade também com os novos funcionários diretamente. Mais nossa obrigação social é de zelar por eles, dar treinamentos, procura abrir horizontes, dar perspectivas (moradora $\mathrm{O}$, proprietária de estabelecimento, entrevista, mar./2013).

Nos arredores do Distrito de São Jorge, os proprietários de terra que possuíam em seus domínios um atrativo natural como um rio, com locais de banho ou cachoeiras, vislumbraram na atividade turística 
uma forma de garantir a sua sobrevivência, abrindo suas porteiras aos turistas, principalmente aqueles nas imediações do Parque, na sua Zona de Amortecimento.

Segundo o Agente Administrativo do Distrito (entrevista, mar./2013) existem na região do Distrito cerca de trinta propriedades com atrativos turísticos ${ }^{6}$. Nessas localidades são cobradas as entradas dos visitantes, com valores variando entre $R \$ 10,00$ e $R \$ 15,00$ por pessoa. Em alguns locais encontram-se alguma infraestrutura para receber as pessoas, como pequenas cantinas, sanitários, entre outros. Em outras, são servidas refeições por encomenda. Em uma propriedade foi possível observar, quando do trabalho de campo (março de 2013), uma pequena pousada, em outra, uma estrutura de um palco para apresentações artísticas.

Em todas essas propriedades, a grande maioria emprega mão de obra familiar, seja das pessoas que moram nos estabelecimentos, em épocas de menor movimento, seja de pessoas da família, provenientes de outra localidade, na época da alta temporada. Numa propriedade, às margens do rio São Miguel, cujo atrativo principal são as corredeiras por entre as formações rochosas, conforme relatou um de seus proprietários, trabalham em média 17 pessoas nos finais de semana, na época de menor movimento, e cerca de 30 pessoas, no período da alta temporada, "tudo da família". Ainda, na alta temporada, o mesmo frisou, vindas de fora mais 3 a 4 pessoas para ajudar no atendimento do serviço de cantina, mais 2 guias, que permanecem o dia todo próximos ao curso do rio, orientando as pessoas e um socorrista profissional, para atender os visitantes, em casos de emergência. Quanto ao número de visitantes ao local, o proprietário informou que em finais de semana, "na alta temporada, deve passar umas 400 pessoas por dia, e na baixa temporada, de cem a cento e poucas" (morador D, ex-garimpeiro, proprietário rural, entrevista, mar./2013).

Segundo o morador A, ex-garimpeiro e também proprietário de terras, quando cessaram as atividades de garimpagem, continuou com o trabalho agrícola por mais um período de tempo, deixando-o também pelo pouco rendimento que proporcionava e as condições topográficas do terreno, e já vislumbrando as oportunidades da nova atividade, o turismo. Em sua propriedade encontra-se, atualmente, um dos principais atrativos do entorno, na região do Distrito de São Jorge, as cachoeiras do Segredo.

Depois do garimpo, eu mexia com lavoura, mexia com gado, comprava gado e vendia. Sabe o que eu fiz? Lavoura não dava nada, minha terra é muito acidentada, preservei tudinho. Parece que tava adivinhando, não derrubei mais nada, não fiz roça, não fiz nada. Faz uns trinta e tantos anos (morador A, exgarimpeiro, entrevista, mar./2013). 
Outro produtor acrescenta que depois do desenvolvimento do turismo na região, a atividade agrícola propriamente dita ficou inviabilizada, uma vez que os ganhos com o turismo podem se sobrepor aos rendimentos de uma exploração leiteira, por exemplo.

Seria imbecil da minha parte, enquanto meu vizinho ali acorda de madrugada, tira leite, cuida de bicheira, cuida da vaca, não sei o que, faz um queijo pra vender por dez contos (R\$10,00), a visita chega aqui, já traz os dez contos, eu ainda to dormindo (proprietário rural C, entrevista, mar./ 2013).

Outro fato que foi mencionado pelos produtores da região e que de certa forma restringiu as atividades agrícolas no entorno do Parque foi a criação da Zona de Amortecimento, com a finalidade de amenizar as atividades humanas para diminuir os impactos negativos sobre as UC, ainda que a lei que instituiu o SNUC, em 2000, trouxesse em seu bojo objetivos ligados à questão do desenvolvimento socioeconômico das comunidades adjacentes a estas unidades.

Dessa forma, nessas localidades, as atividades econômicas deveriam estar em consonância com as atividades de conservação dos recursos naturais, o que contribuiu para reverter o modo de agir das pessoas que aí habitavam, obrigando-as a buscar uma nova forma de sobrevivência e desenvolver outras atividades, que não aquelas tradicionais ou de costume.

O turismo tá fazendo a gente viver, porque se não fosse o turismo, porque a gente não pode inventar coisa, derrubar (mato) e fazer uma roça, não pode, o IBAMA (atualmente ICMBio) tá bem ali, o IBAMA comanda $10 \mathrm{Km}$ ao redor, não deixa fazer nada, a não ser alguma estrutura prá aqui mesmo no local, não pode tirar nada prá fora, só prá dentro (morador D, ex-garimpeiro, proprietário rural, entrevista, mar./2013).

As pessoas do núcleo urbano do Distrito de São Jorge, bem como aquelas residentes na Zona de Amortecimento do PNCV, se viram impelidas, pela força da lei, a desempenhar atividades ligadas ao turismo, deixando de lado as suas práticas antigas como a garimpagem, o extrativismo e a atividade agrícola ligada à subsistência, uma opção imposta a partir da criação do Parque Nacional na região.

A supervisora da unidade local da EMATER (entrevista, set./2013) afirma essa tendência da localidade de se apoiar produtiva e economicamente na atividade turística:

Diferentemente de outras regiões mais próximas (da sede do município) e com caráter de produção agropecuária, São Jorge dista muito desta característica, pois foca a sua produção para um público também diferenciado, em função da presença do PNCV. As demais regiões produtoras do município têm maior participação em grupos organizados, cooperativas (PAA - Programa de Aquisição de Alimentos da Agricultura Familiar e PNAE - Programa Nacional de Alimentação Escolar), associações, conselho rural, Território da Cidadania Chapada dos Veadeiros e afins. 
Mesmo aqueles produtores que se dedicam à atividade agrícola, como destaca a extensionista da EMATER, buscando uma produção especializada para atender uma demanda proveniente do turismo: "alguns produtores que lá existem atendem exclusivamente à necessidade deste público no distrito e um exemplo disso é o Sr. X, que produz queijo para atender às pousadas" (Supervisora da EMATER, entrevista, set./2013).

Outro fator limitante para os agricultores da Chapada, conforme relata um agente da AGRODEFESA, é que praticamente toda a extensão da área do município de Alto Paraíso de Goiás está na APA do Pouso Alto, ocupando cerca de "96\% de seu território". Embora, dentre as UC, as APA deem uma maior flexibilidade no que diz respeito à exploração dos recursos naturais de uma região, o plano de manejo da APA do Pouso Alto ainda inexiste, em função dos problemas pendentes relacionados à posse da terra na localidade, dificultando o acesso dos produtores rurais às políticas voltadas para o setor agrícola.

Esse plano de manejo ainda não foi feito porque não há regularização fundiária no município. E essa regularização fundiária é um dos principais gargalos para acessar crédito, para todas as políticas que se desenvolvem no campo. É necessário que haja a regulamentação fundiária, a falta dela promove um grande prejuízo aos produtores, de uma forma geral, dentro de um único contexto (agente da AGRODEFESA, entrevista, jul./2013).

Assim, com o funcionamento do Parque Nacional, foi traçada uma nova configuração nas relações sociais, econômicas, culturais e ambientais na região. Aos nativos e primeiros moradores, tanto do Distrito de São Jorge, quanto de suas imediações, somaram-se as pessoas advindas de outras localidades, que buscavam na atividade turística uma oportunidade, e também, os turistas, atraídos pelas atividades naturais do lugar, sua beleza cênica e suas amenidades.

Nesse sentido, assegura Silva (2003b) pode-se evidenciar diversos sentimentos e significados por parte dessas pessoas, interferindo nas suas atitudes e valores acerca do local, uma área natural que exprime em tempos diversos, sucessivas relações entre o homem e a natureza, "seja pela beleza estética exposta à contemplação, por ser fonte de renda, seja pela possibilidade de qualidade de vida ou pelas novas relações sociais, o Parque é dotado de valores socioculturais" (SILVA, 2003b, p. 83).

Com o desenrolar da atividade turística, os moradores do Distrito de São Jorge puderam mudar sua posição frente ao Parque Nacional, antes vistos como um obstáculo à implantação da UC, passaram a ser defensores de seu uso responsável, mesmo que se tenha um interesse econômico atrelado a essa questão, como salientou Barbosa (2008, p. 65): "o advento do turismo proporcionou desenvolvimento 
econômico e social à viabilidade ambiental, por causa do compromisso dos seus moradores com a conservação de sua maior fonte de renda, o PNCV".

A criação da UC na localidade, mesmo interrompendo o ciclo de uma atividade que deu origem ao Distrito, tem um significado de mudança, de transformação não só do espaço das pessoas, como no seu modo de viver, da sua relação com o ambiente.

Em contrapartida, as mesmas pessoas que viveram a experiência dessa atividade viram o seu ir e vir, em função das demandas do cristal no mercado internacional, ao longo do tempo, com pessoas ora "bamburrando", como diziam os garimpeiros ao acertar um veio de cristal e "fazendo muito dinheiro", ora no "blefe", quando "não arranjava nada" e precisavam se socorrer da agricultura de subsistência, da "lavoura" para garantir o "sustento", presenciaram a chegada da nova atividade, o turismo, e viram na mesma uma oportunidade, em seu próprio ambiente:

Quando os turistas vêm chegando em visita à região, desapareceram os compradores de quartzo de cristal. Foi chegando muito visitante e o povo de São Jorge começou a crescer os passos, foram melhorando. São Jorge hoje tem boas pousadas de luxo e camping, restaurante, associações de guias e outras. Os moradores sobreviviam de garimpagem e hoje vivem da associação ${ }^{7}$. De 1990 para cá, o recurso é este: receber o turista (OLIVEIRA, 2009, p. 30).

O Parque Nacional, juntamente com os atrativos de seu entorno, transformou-se na referência de um cenário de grande valor para as pessoas do meio urbano que buscam um contato com a natureza, por intermédio do lazer e recreação e, o local, "antes território de garimpeiros torna-se palco e suporte da atividade ecoturística" (SILVA, 2003a, p. 56).

E o Distrito de São Jorge e suas imediações, por ser o marco do portão de entrada do PNCV, de certa forma atraem as atenções por sua localização e adquire uma posição especial no município, com relação ao turismo na região, fato que pode ser notado no que expôs o Agente $A$ da Administração Municipal (entrevista, jul./2013):

Eu até digo que São Jorge é a nossa galinha dos ovos de ouro na questão do turismo, porque se a gente pudesse dizer que aquela região é nosso principal produto turístico. Em São Jorge é o que tem acesso ao Parque Nacional. As áreas de uso público do Parque Nacional são grandes atrativos. Na região de São Jorge nós temos o atrativo privado mais visitado da região toda nossa, que é o Vale da Lua.

Embora, para a administração municipal, a região do PNCV e do Distrito de São Jorge seja o principal produto turístico do município, muitos entrevistados (moradores, comerciantes) reclamaram da ausência de ações do poder público municipal para desenvolver a atividade turística no local, 
apontando para questões relacionadas à dificuldade de aceso e tráfego pelo distrito, pelo fato de parte da estrada GO-239 não estar asfaltada (14 km), as ruas sem pavimentação e esburacadas.

Por sua vez, o Agente A da Administração Municipal (entrevista, jul./2013) assegura que um dos principais problemas do Distrito, que reside na coleta de lixo, está sendo resolvido com um processo de terceirização. Outra preocupação se refere à manutenção das estradas vicinais da região, para o acesso aos atrativos turísticos, em que a prefeitura municipal cede as máquinas para o serviço, recebendo em contrapartida, dos proprietários, o pagamento dos custos operacionais.

Essa ideia do Parque Nacional e os atrativos do seu entorno constituírem-se na "galinha dos ovos de ouro" é recorrente entre alguns moradores, principalmente daqueles que veem no Parque a oportunidade de tirar um proveito financeiro com a atividade turística, sem se importar com os impactos que a atividade possa causar. Entretanto, algumas pessoas questionam esse pensamento e ponderam, apontando para uma consciência que busque uma alternativa mais próxima de um desenvolvimento mais sustentável do turismo

Então a gente precisa convergir essas ideias e ver uma coisa do todo. Não é simplesmente ver o Parque, o que eu vejo, que a relação do Parque é como se fosse uma prostituta, sabe, é forma de ganhar dinheiro - eu quero dinheiro. Ninguém vai ficar rico com o ecoturismo, não fica, porque a natureza não tá aqui prá isso. Mas dá prá gente viver e ter qualidade de vida, se a gente tiver sabendo o que a gente quer (moradora F, ex-garimpeira, dona de estabelecimento, entrevista, mar./2013).

O Parque Nacional tornou-se o carro chefe do turismo desenvolvido na Chapada dos Veadeiros, desde o início da organização da atividade na região, nos anos 1990, quando anteriormente a essa data, a entrada era livre e os visitantes sobre-exploravam seus recursos, comprometendo a sua conservação. Esse fato levou à proibição do livre trânsito de pessoas na UC e provocou um colapso financeiro no Distrito de São Jorge, que já se engrenava na nova atividade.

No início de 1991, o Departamento de Unidades de Conservação do IBAMA, em alerta para a exploração descontrolada do ambiente e visando à preservação de seus atrativos, determinou o fechamento do Parque para visitação pública. Alegou que o local não tinha condições de receber o intenso fluxo turístico devido à falta de infraestrutura, à insuficiente quantidade de pessoal para a fiscalização e à desinformação e má conduta dos usuários. Esse fechamento que durou praticamente todo ano, causou grandes prejuízos e transtornos para os donos de pousadas e restaurantes de São Jorge (BRANDÃO e BARRETO, 2009, p. 363).

A importância do Parque Nacional para o Distrito pode ser detectada quando em entrevista aos proprietários de estabelecimentos comerciais e de prestação de serviços local, relataram que o movimento de seus estabelecimentos caminha, conforme a visitação e o funcionamento do mesmo: 
O Parque é como se fosse o coração da Vila aqui, que estamos em volta dele. Porque o visitante confunde, fechou o Parque, ele acha que fechou foi tudo, não sabe que tem outros atrativos em volta. Então é muito importante, se falar que fechou o Parque, aqui o turismo cai $80 \%$ (morador $\mathrm{M}$, ex-condutor e proprietário de estabelecimento, entrevista, mar./2013).

Levando em consideração que a gente tem outros atrativos particulares belíssimos, talvez até mais bonitos que o Parque Nacional, mas se o Parque Nacional fecha o turista não vem. Ele pode até não visitar o Parque, mas na cabeça dele, quando o Parque não tá funcionando, a Chapada é como se tivesse fechada também, as portas.

O Parque é o que chama o visitante aqui, ele é o carro-chefe (moradora F, exgarimpeira, proprietária de estabelecimento, entrevista, mar./2013).

Se o Parque acabasse hoje, a gente poderia fechar as portas e ir embora, porque as pessoas não vêm prá cá, prá ir prá Morada do Sol, ir prá outros lugares. Se fosse simplesmente prá ir pro Vale de Lua, elas ficariam em Alto Paraíso e poderiam vir no Vale da Lua. Mas, por causa do Parque, acho que $90 \%$ do fluxo de turismo aqui é por causa do Parque Nacional (morador $\mathrm{P}$, proprietário de estabelecimento, entrevista, mar./2013).

Percebe-se que o Parque Nacional dita o ritmo da atividade econômica e movimento de pessoas no Distrito, o que pode ser observado no fluxo de visitantes na localidade nas épocas de alta temporada, coincidente com o mês de julho, e de baixa temporada, no mês de março.

Além da questão econômica, diretamente relacionada com a ambiental, pode-se notar que na região, - Parque Nacional tem uma representação muito grande na vida das pessoas da localidade, principalmente daqueles que vivenciaram as várias fases, que aí se desenrolaram. Para essas pessoas as representações possuem uma ligação com as suas percepções do meio onde estiveram e estão inseridas.

Segundo Silva (2003b, p. 71), “a percepção é sempre acompanhada de valores e esses estão ligados aos padrões culturais vigentes na sociedade", especialmente aqueles que garantem a sobrevivência das pessoas em um dado momento.

Dessa forma, foi se criando uma experiência social e histórica das pessoas numa relação de trocas com o ambiente, criando uma forte vinculação com a localidade, de ser daquele local, de ter passado a vida toda ali acompanhando as suas transformações, tendo vivenciado a mudança no padrão de valores desde a época da garimpagem até o momento em que o local se transformou em uma UC. "É nesse contexto que produzem seus saberes e fazeres e constroem seu campo indentitário. Uma identidade tecida com e no ambiente onde suas histórias de vida foram construídas" (SARAIVA, 2012, p. 211-212). Ao ser questionado sobre o que o Parque representava em termos de valor, o morador $\mathrm{G}$, exgarimpeiro, em entrevista em março de 2013, afirmou: 
Desde criança, às vezes, quando tinha 6 ou 7 anos, eu estava na escola, às vezes a escola era cedo, eu ia à tarde mais meu pai, ao menos servir ele de companheiro prá garimpo.

Prá mim é muita coisa, é tudo. Até pela preservação, não é? Porque eu tô com 58 anos. É pelo futuro dos que vão vir.

Para Mazzetto Silva (2009, p. 100-101), as pessoas dessas localidades apresentam "uma íntima relação com esses lugares que habitam e essa relação histórica produz um conhecimento ancestral desses ecossistemas e de seu uso." O autor reforça ainda que, para as mesmas o cerrado é o "lugar de viver" e destaca um sentido de pertencimento na relação com o local em que vivem ao qualificá-las como "povos do Cerrado".

As interrelações que vão se formando entre o homem e o meio estabelecem formas peculiares de cada grupo social, envolvendo toda uma gama de representações com e naquele espaço. Silva (2005, p. 40) ressalta que

\begin{abstract}
A paisagem de um parque nacional para os moradores locais envolve sua própria história de vida, formada por um conjunto de símbolos, valores e sentimentos ligados à sua maneira de ver e harmonizar com o espaço vivido. Construindo e reconstruindo traços definidores na sua relação com o mundo natural e imaginário, esses grupos revelam sua forma própria de viver, perceber e experenciar a paisagem, criar suas raízes e seus lugares. [...] Isto nos possibilita entender que as relações entre homem e a paisagem constitui uma rede de significados e sentidos que são construídos e reconstruídos conforme as transformações históricas, sociais e culturais.
\end{abstract}

Uma identidade que foi se moldando em virtude dos acontecimentos que foram transcorrendo na localidade e que, atualmente, reflete os objetivos de uma UC, valorizando aquele patrimônio, como afirmou a Agente A da Administração do Parque Nacional (entrevista, mar./2013)

O maior valor de um Parque Nacional é quando a sociedade, principalmente aqueles que estão ali do lado, eles valorizam, eles veem essa importância. É quando a sociedade que tá ali, ela reconhece aquilo (UC) como algo importante. Ela vem aqui, igual já vieram algumas pessoas e reclamam que o Parque foi diminuído em três vezes; vem aqui e reclama porque a gente quer abrir uma trilha; vem aqui e reclama porque a gente escreveu nas pedras, rabiscou as setinhas na pedra. Isso quando vem de uma pessoa, não de um ambientalista, quando vem de uma pessoa, igual o Sr. Y., aí você vê que ele tem um apego mesmo, é uma questão mesma de pertencimento: "Isso aqui faz parte da minha vida, não é só o meu ganha-pão".

O depoimento apresentado pode ser corroborado pelo que afirma Silva (2004), quando se trata da ligação das pessoas da localidade com a região, que transcende a esfera econômica, dos valores que podem ser auferidos com a prática turística em função da beleza cênica do lugar, mais em um contexto 
maior que envolve a história das pessoas, "a paisagem do parque não é, apenas, uma expressão dos atributos da natureza expostos à apreciação estética. Essa paisagem é, principalmente, o resultado de sensibilidades, de saberes e, antes de tudo, horizonte de vida" (SILVA, 2004, p. 11).

Pelo que expôs anteriormente a Agente A da Administração do PNCV, percebe-se que as pessoas do Distrito de São Jorge ainda têm uma preocupação econômica relacionada à conservação dos recursos do Parque Nacional, mas associada a essa questão pode-se observar uma mudança na conduta das pessoas, fruto de um processo instalado na região, com o advento do turismo, levando-as a valorizar também a questão ambiental. "Uma atividade socioeconômica modificou um modo de agir das pessoas, que buscavam a melhoria de suas condições de vida, atuando em seu plano condutual e interferiu em seus comportamentos em relação ao meio no qual estavam inseridos, não deixando de ser também uma ação educativa" (DOMICIANO, RIBEIRO e SILVA DOMICIANO, 2013, p. 556).

No tocante à mudança de comportamento das pessoas da localidade, novos valores são incorporados ao seu cotidiano em função do ecoturismo, "A realização de uma educação, enquanto processo permanente com base nas preocupações ambientais e transformação de mentalidades possibilita a preservação dos valores naturais e culturais, os quais sustentam a atividade turística" (SILVA, 2005, p. 42).

Em função da organização da comunidade e até de um movimento que ganhou força no Distrito, tentando focalizar um turismo de base comunitária e com viés mais sustentável, a questão ambiental, para algumas pessoas da localidade ganhou uma importância maior, quando se trata do valor do Parque Nacional.

\footnotetext{
O Parque Nacional, o valor dele maior prá mim, dentro de uma esfera não econômica é poder garantir, apesar da nascente do Rio Preto não nascer dentro do Parque, mas ter outras nascentes. Eu acho que o valor maior é poder garantir as espécies. As espécies que nós temos lá de todas as plantas, o conjunto de animais e tudo. É o que garante a vida para o planeta mesmo [...]. Se a gente não tem isso, você deixa de garantir, talvez, vida para as próximas gerações (moradora F, ex-garimpeira e proprietária de estabelecimento, entrevista, mar./2013).
}

Percebe-se então a formação de uma consciência de valor das pessoas, relacionada à questão da conservação dos bens e serviços do PNCV, mesmo que esses valores estejam fortemente ligados a garantia de sua renda. 


\subsection{E AGORA?}

Era para representar tudo, só que agora não tá representando mais nada, porque na verdade a gente mostrava as belezas para poder sobreviver (morador L, ex-garimpeiro e condutor de visitantes, entrevista, mar./2013).

Um fato que aconteceu no início de 2013, envolvendo a comunidade do distrito de São Jorge e a gestão do PNCV, relacionado à condução dos visitantes ilustra essa questão do valor que a UC tem para as pessoas da localidade, não só no aspecto econômico, mas também no social, cultural e ambiental.

O serviço de condução de visitantes foi um "arranjo" encontrado pelo IBAMA, no início dos anos 1990, para possibilitar que a comunidade de São Jorge encerrasse de vez a atividade de garimpagem no interior do Parque Nacional e passasse a se integrar de forma efetiva na defesa e manutenção da UC, com a prestação de serviço na condução de visitantes, nas trilhas abertas ao público.

Inicialmente, pagava-se uma taxa de entrada no Parque e uma para o condutor de visitantes. Depois de um tempo, essa taxa de entrada foi extinta, e o pagamento pela visita ao Parque ficou restrito somente à taxa do condutor. Segundo Ribemboim (2004, p. 6) "essa foi uma das formas encontradas pelo IBAMA para que parte dos gastos realizados pelos visitantes fosse revertida em alguma renda para o lugar" e constituiu-se "numa fórmula positiva para se conseguir o apoio da população local, tornando mais fácil a defesa do parque contra a depredação".

Essa parceria entre a UC e a comunidade prevaleceu de 1991, quando o Parque Nacional foi reaberto à visitação, até janeiro de 2013, tendo a administração da unidade adotado como norma a obrigatoriedade da contratação do serviço de condução de visitantes, embora desde de 2008, a Instrução Normativa (IN) $n^{\circ} 08$, do ICMBio, que trata da prestação de serviços vinculados à visitação e ao turismo em Unidades de Conservação Federais, por condutores de visitantes, passou a não exigir mais essa obrigatoriedade.

Em contato informal, com a chefia da UC, que antecedeu a chefia atual, o responsável alegou que tentou manter a obrigatoriedade da condução enquanto foi possível, como forma de garantir a renda das pessoas que se ocupavam dessa função, até que a partir de 10 de janeiro de 2013, a IN 08 do ICMBio, entrou em vigência definitivamente. Essa ocorrência causou uma tensão na comunidade, principalmente entre os condutores de visitantes, que tinham no serviço de condução nas trilhas do PNCV a sua principal fonte de renda. 
Essa medida foi tomada em um momento em que o ecoturismo chama a atenção da sociedade brasileira em virtude de seus números potenciais, como indicou um estudo realizado por diversas organizações de pesquisa, a pedido do MMA.

A visitação aos 67 Parques Nacionais existentes no Brasil tem potencial para atrair cerca de 13,7 milhões de pessoas por ano, entre brasileiros e estrangeiros, considerando investimentos planejados e o incremento do turismo projetados para o país em 2016. Esse fluxo de visitantes pode gerar, aproximadamente, entre 1,6 bilhão (cenário conservador) e 1,8 bilhão (cenário otimista) para as regiões onde estão localizados os parques nacionais, garantindo recursos para sua manutenção e dinamizando a economia local (MEDEIROS et al., 2011, p. 22).

Segundo Seabra (2013, p. 28-29), muitos parques nacionais foram criados no Brasil e a maioria deles apresenta problemas relacionados ao cumprimento de seus objetivos: "uma das contradições é a transformação dos parques nacionais em mercadorias para consumo de massas". Outro problema apontado pelo autor foi a ausência do Estado na proteção e fiscalização das UC e o espaço deixado nessa área para as ONG, com suas propostas de uso sustentável dos recursos naturais, passando a atuar com o governo federal na co-gestão dessas áreas protegidas (SEABRA, 1998; 2001).

Para Rodrigues e Godoy (2013, p. 84), “é desejável que essa atribuição seja desenvolvida em conjunto (parceria) com as empresas, comunidades locais e organizações da sociedade civil envolvidas na prestação de serviços de apoio à visitação nos parques nacionais e demais unidade de conservação".

Essa tendência de atrair a iniciativa privada para a gestão dos parques nacionais entrou em voga, em alegação de que os esforços do governo não eram suficientes para atender a prática do ecoturismo nas UC, uma vez que as mesmas não dispunham de planos de manejo, infraestrutura e condições para receber os visitantes. Dessa forma, a saída encontrada seria a abertura das UC para "investidores privados com base nos respectivos planos de manejo e nos estudos de viabilidade técnica e econômica" (ROCKTAESCHEL, 2006, p. 126).

Inserido nesse contexto mais amplo, Seabra (2013, p. 29) menciona

Para facilitar este processo, o Governo Federal criou em 2007, o Instituto Chico Mendes de Conservação da Biodiversidade - ICMBio, destinado a viabilizar a administração das unidades de conservação, mediante convênios assinados com o terceiro setor e licitações direcionadas às empresas prestadoras de serviço e operadoras de turismo.

O autor cita como exemplo dessas terceirizações o caso da empresa concessionária que atualmente administra os serviços de venda de ingressos, transporte, restaurantes e lojas no Parque Nacional do Iguaçu e que também opera no Parque Nacional de Fernando de Noronha. 
Em unidades de conservação com um volume de visitação alto, esse processo de terceirização pode até funcionar, asseguram Rodrigues e Godoy (2013, p. 86): “No caso do Parque Nacional do Iguaçu, o alto fluxo de visitantes, em comparação com todos os demais parques nacionais, é uma das principais justificativas para a consolidação de serviços compatíveis com essa demanda". Mas questionam se essa medida pode ser válida e viável em um parque com um fluxo de turistas médio ou pequeno inferior, por exemplo, a trinta mil visitantes por ano. No caso do PNCV nos últimos seis anos a visitação anual média ficou em torno de vinte mil pessoas.

Outrossim, as autoras ponderam a respeito desse processo de prestação de serviço que envolve as questões ambiental, econômica e social.

Nesse ponto, emerge a discussão sobre a ética que orienta o processo de prestação de serviço nos parques nacionais. Isso se coloca tanto em termos ambientais, que trazem à tona a questão da supremacia do mercado frente à conservação da natureza, quanto em termos socioeconômicos, que dizem respeito aos arranjos institucionais que possibilitem a inserção dos atores locais no processo de prestação de serviços (RODRIGUES e GODOY, 2013; p. 86).

Silva (2004, p.11) mencionou que a comunidade local argumenta que, diante da possibilidade da privatização ou terceirização dos serviços de visitação do PNCV, os moradores do Distrito se credenciariam, por intermédio de suas organizações, principalmente, a ACVCV, como os "mais capacitados" para assumirem essas atividades, visto que "almejam esse compromisso, acrescentando que são eles os maiores protetores do Parque".

Barbosa (2008) enfatizou as alterações no SNUC, principalmente aquelas relacionadas à gestão compartilhada das UC com uma Organização da Sociedade Civil de Interesse Público (OSCIP), no que se refere à exploração dos serviços relativos à visitação, recreação e turismo, aventando que essa possibilidade no PNCV inquietava os moradores do Distrito de São Jorge.

Em casos específicos, como o do PNCV, Rodrigues e Godoy (2013) enfatizam que a participação da comunidade é primordial, principalmente para alavancar o desenvolvimento local. "As iniciativas de micro e pequeno porte, por exemplo, tendem a possibilitar uma maior participação das comunidades locais na prestação de serviços de apoio à visitação, pois permitem uma composição com um reduzido investimento e com base em insumos locais" (RODRIGUES e GODOY, 2013; p.86).

Conforme observado e em entrevistas realizadas com agentes administrativos do PNCV, não existe nenhum processo de terceirização dos serviços relacionados ao turismo na unidade. O efetivo cumprimento da IN $\mathrm{n}^{\circ} 08$ do ICMBio foi uma decisão que se aplicou a todos os parques nacionais, 
como declarou a Agente A da Administração do PNCV (entrevista, mar./2013), que também frisou o caráter de excepcionalidade da obrigatoriedade do serviço de condução de visitantes na UC.

A guiagem opcional não foi algo que a equipe do Parque decidiu: Vamos tirar isso e pronto. É uma normativa, ela é aplicada no Brasil todo. Então, assim na verdade, essa peculiaridade da Chapada, ela era realmente uma peculiaridade. Não tem outros lugares do Brasil que tenha essa obrigatoriedade, os lugares que tem é porque tem alguma especificidade, que exige a condução obrigatória, por exemplo, caverna, pintura rupestre.

Antes da aplicação da IN $n^{\circ} 08$ do ICMBio, algumas reuniões foram realizadas entre a administração do PNCV e representantes dos condutores de visitantes para o esclarecimento da situação, segundo relatos de alguns moradores e proprietários de estabelecimentos turísticos, mas não se chegou a nenhuma providência a ser tomada para que se encontrasse uma saída alternativa para o fim da obrigatoriedade do serviço de condução no interior do Parque. O presidente da ACVCV argumentou que a aplicação da IN $n^{\circ} 08$ do ICMBio não levou em consideração a realidade da maioria dos condutores de visitantes da localidade, comunicando-se que era uma norma a ser cumprida.

Eles fizeram tudo e chegou aí e implantou e deixou. Isso aqui é uma Normativa de 2008, para todos os Parques Nacionais, que é parte de uso público, que tem guia, agora não será mais obrigatório. Sendo que não ouviu a comunidade, não ouviu nem um garimpeiro, não viu a história, eles chegaram aqui, simplesmente falou: Normativa tem que cumprir (morador $\mathrm{H}$, ex-garimpeiro, condutor de visitantes, entrevista, mar./2013).

Nesse período em que a IN n 08 do ICMBio começou a ser aplicada, houve a troca de chefia do Parque Nacional. Essa nova chefia tem procurado estabelecer contato com as lideranças da comunidade, inclusive, foi possível participar de uma reunião de boas vindas da mesma com os representantes das entidades e associações do Distrito, com o representante da Administração Local. Nessa reunião observou-se que as pessoas da localidade estavam reticentes em relação a essa questão, e não se tratou especificamente do assunto. A Agente A da Administração do Parque afirmou em entrevista (mar./2013) que tem se reunido em isolado, com as pessoas da localidade, principalmente com os condutores de visitantes, para falar do problema.

Essas atitudes demonstraram um protocolo de boas intenções, conforme relatos de alguns moradores locais, no estabelecimento de relações com a comunidade:

Cada um (chefe do Parque) teve o seu legado, fez uma coisa, a gente foi construindo tudo isso [...] eles são parceiros em potencial para ajudar aqui (moradora F, ex-garimpeira, proprietária de estabelecimento, entrevista, mar./2013). 
Segundo a Agente A da Administração do PNCV (entrevista, mar./ 2013), nota-se um constrangimento que se dá em função do rompimento de um acordo realizado entre a administração da UC e os exgarimpeiros, que viabilizou a situação do local para a visitação, e que para os condutores de visitantes, além da questão econômica, de ser o "ganha-pão" tem um valor sentimental que se perde nesse momento.

Foi feito um acordo no passado, que o Parque estava largado, e foi feito um acordo com os guias. Eles que deram de alguma forma, uma organizada no Parque. Então eu sinto assim que muitos estão se sentindo rejeitados agora.

Esses arranjos, como Diegues (2001, p. 120) qualificou de "acordos mais ou menos informais com instituições oficiais do meio ambiente, como o IBAMA", se deu no Brasil em função do processo de redemocratização do país, com o fortalecimento da sociedade civil, por meio de sua organização em associações, sindicatos, organizações não governamentais, movimentos sociais, etc. Assim, as comunidades locais puderam de certa forma garantir o seu modo de vida ou adequarem-se às situações locais, como foi o caso dos ex-garimpeiros que se tornaram condutores de visitantes mediante um acordo com o IBAMA e várias entidades interligadas pelo Projeto Veadeiros.

Ainda segundo o autor, não houve uma movimento maior em nível nacional que desse respaldo e notoriedade a esses acordos, que agora vão perdendo a sua validade, e também contribui para essa situação uma legislação ambiental inadequada, que não beneficia as comunidades das áreas naturais protegidas (DIEGUES, 2001).

Durante as duas últimas estadas no Distrito de São Jorge, em março e início de julho de 2013 (as férias escolares ainda não haviam iniciado) foi possível constatar pouca movimentação de condutores de visitantes com seus grupos, na entrada do Parque Nacional e nas ruas da localidade, em virtude de ser um período coincidente com a baixa temporada.

Entretanto, segundo os relatos das pessoas da comunidade, a medida da não obrigatoriedade na condução de visitantes nas trilhas do Parque Nacional interferiu na vida das pessoas da comunidade, principalmente no aspecto socioeconômico, como se pode denotar nos relatos a seguir, de um comerciante, e de dois condutores de visitantes:

Depois que eles abriram a portaria do Parque, acabou com a comunidade. Porque a sobrevivência dos guias era o turismo, que vinha cá guiava, ganhava cem reais por uma guiagem. Chegava aqui, comprava uma bolacha, comprava água, comprava um cigarro e comprava mais alguma coisa. Hoje você não vende nem balinha mais, porque não tem dinheiro, como é que você vai fazer, não são empregados. Como é que você vai fazer, não tem renda. (morador $\mathrm{N}$, excondutor de visitantes, dono de estabelecimento, entrevista, mar./2013). 
Hoje entrou dois grupos, entrou seis pessoas sem guia. Então essas seis pessoas já podia pegar um guia e levar, já aproveitava é já ter um dinheirinho prá hoje. A gente vem da roça muito quebrado. Eu trabalhei uma rocinha lá, tô cuidando de uma rocinha lá perto de Colinas num assentamento (de trabalhadores semterra) (morador J, ex-garimpeiro, condutor de visitantes, entrevista, mar./2013).

Qualquer um dinheirozinho com a guiagem dava prá sobreviver. Agora hoje, tirando (a condução de visitantes) é que não dá, isto sim, porque hoje ninguém arranja serviço. Até porque não tem lavoura (morador G, ex-garimpeiro e condutor de visitantes, entrevista, mar./2013).

Nos depoimentos dos condutores de visitantes, é possível depreender que os mesmos têm um vínculo com a atividade agrícola (lavoura). Para o primeiro a solução foi se deslocar da localidade para um acampamento de trabalhadores rurais sem terra, no município de Colinas do Sul. Para o outro, que alegou não ter condições de sair do Distrito de São Jorge, até a lavoura, que à época do garimpo garantia o sustento, agora já não é mais uma alternativa.

Para mostrar a importância da atividade para as pessoas que se dedicavam à condução de visitantes nas trilhas do Parque, mesmo que sob uma ótica econômica, percebe-se que a medida da desobrigatoriedade trouxe uma repercussão que afeta a vida das pessoas e da localidade. Por enquanto, a contabilização desses efeitos é monetária, e tem sido ressaltado o que se deixa de ganhar com a atividade em um determinado período. Ainda não se fez outra análise desse âmbito, como resumiu um morador, ex-garimpeiro e condutor de visitantes (entrevista, mar. 2013):

Durante um feriado aí, dá uns 15 mil (reais), nessa parte aí. Esse dinheiro fica tudo dentro de São Jorge, vai pros armazéns, vai prá qualquer coisa. Então o povo aqui, praticamente sobrevive do turismo e, tirando a obrigatoriedade do guia, ficou muito difícil.

Mesmo com essa celeuma criada recentemente em torno da não obrigatoriedade da condução de visitantes nas trilhas do Parque Nacional, o mesmo representou e representa um elemento transformador na realidade das pessoas da região, principalmente do distrito de São Jorge. De uma atividade depredatória que era a garimpagem, as pessoas conseguiram com o turismo, advindo da existência da UC modificar seu modo de vida, alteraram o seu plano condutual para atividades em consonância com os princípios da conservação ambiental, "reinventando cotidianamente os valores que os mantêm ligados à natureza", como afirmou Guanaes (2006, p. 203).

Essa relação com o meio natural, por intermédio do turismo, permitiu a sobrevivência socioeconômica da maioria das pessoas do Distrito de São Jorge, ao 
Propiciar à população local conhecimentos que viabilizem formas de ver a paisagem não somente como um produto a ser comercializado, mas acima de tudo que reconheça nela parte de sua história, do seu modo de vida, das suas lembranças, enfim, sua identidade. Quando o morador tem plena consciência do valor do seu lugar ele se dá conta de que a conservação é vital (SILVA, 2005, p. 42).

Dessa forma esse espaço passou por uma ressignificação de valores, mesmo que visto sob a ótica de "um olhar urbano sobre a natureza" como afirmou Rodrigues (2012, p. 244) e precisa "ser percebido também como reserva natural e cultural que deve ser respeitada e preservada". E que ao mesmo tempo tornou-se, como frisou Froehlic (2012, p. 204), um elemento de consumo dessas sociedades urbanas, ao usufruir de seus "bens simbólicos e materiais, e de práticas culturais, reconhecidos como próprios do dito mundo rural".

A atividade turística, ainda que pesem alguns aspectos que venham causar certos impactos no ambiente e às pessoas da localidade, apresenta vários benefícios socioeconômicos para a comunidade aí residente, pois propõe "a produção e/ou reconstrução do espaço e pelo surgimento de novas relações sociais" (RODRIGUES, 2012, p. 245) nesse meio. Também induz à reestruturação dessas localidades e trazem "a incorporação de novos 111

valores, novos hábitos e novas técnicas", desencadeando o processo denominado de ruralidade (FROEHLIC, 2012).

Essa atividade reforça a multifuncionalidade, uma característica atual marcante das áreas rurais ao lançar como desafio o que indica Rodrigues (2012, p. 245): "conciliar as funções 'turística', 'agrícola', 'ambiental' e 'social' do espaço rural sem comprometer os recursos naturais e as práticas tradicionais (aspectos culturais e econômicos)".

O PNCV tornou-se o principal catalisador das atividades turísticas numa região em que tradicionalmente as pessoas se dedicavam à garimpagem do cristal e também, complementarmente à atividade agrícola de subsistência. Nessas condições, o Parque propiciou "novas oportunidades à prestação de serviços ligados diretamente e indiretamente à sua existência" (HAUFF, 2004, p. 174).

Considerando que as áreas contíguas ao Parque Nacional, à exceção das sedes dos municípios de Alto Paraíso de Goiás, Cavalcante e Teresina de Goiás, são áreas eminentemente rurais, a UC tornou-se, como assegurou Hauff (2004, p. 175), um "fator de desenvolvimento local e, também regional, 
impulsionando os demais serviços e infra-estruturas necessárias a um melhor padrão de vida em ambientes rurais".

A região adquiriu uma nova função, com a implantação do PNCV, a de conservação ambiental e manutenção da paisagem e as atividades humanas da localidade se voltaram para esse fim, em um caráter multifuncional, segundo Carneiro $(2009$, p.185) e deve ser analisado "no âmbito dos valores que mobilizam atividades e atribuem outros sentidos a diversas práticas que até então não eram percebidas dentro da prática de 'função pública' porque não estavam inseridas no contexto do que já chamamos de 'ruralidade contemporânea'".

Assim o PNCV apresenta diversos valores para aquelas pessoas que usufruíram e usufruem dos seus bens e serviços. Para os moradores do Distrito de São Jorge, principalmente, esses valores estão arraigados ao seu fazer cotidiano, desde os tempos da garimpagem, ainda que tivessem uma relação "predatória" com esse espaço, até os dias atuais, quando, com a atividade turística, transformaramse, como os mesmos autodenominaram-se, em "anjos da guarda" do Parque, atuando na defesa de seus recursos naturais e de sua biodiversidade.

Para os turistas, o Parque também apresenta uma gama de valores, representados não somente pelo econômico, relacionados aos seus gastos realizados com a viagem para se beneficiarem das amenidades aí existentes, mas também aqueles valores que refletem a

preocupação das pessoas de outras localidades com o conjunto de bens e serviços que a UC possui. Nesse aspecto, Nogueira e Medeiros (1999, p. 66) destacam uma disponibilidade a pagar pela conservação desses bens e serviços, por parte das pessoas, ao destinarem uma parte de sua renda para manter "a existência de uma área de destacada beleza cênica ou um único e frágil ecossistema".

São os valores que o conjunto de bens e serviços do PNCV encerra, e que o transformaram em um elemento que alavancou o desenvolvimento socioeconômico de uma região rural, com base na preservação ambiental, por intermédio da atividade turística, dentro dos parâmetros do que preconiza a multifuncionalidade das atividades em áreas comumente vinculadas à agricultura.

Uma parcela desses valores foi elucidada nessa parte deste trabalho, quando tratou da importância do PNCV para a comunidade do Distrito de São Jorge, em que os valores foram ressaltados a partir de seus vínculos e as representações que tem com o local, deixando transparecer uma valorização desse ambiente por meio de sua historicidade. 
A noção de valores dos visitantes será abordada a seguir, com base numa vertente monetária, porém não perdendo de vista os outros valores atrelados a uma viagem a um parque como o PNCV, que agrega valores de natureza econômica, social, cultural e ambiental.

\section{VALORAÇÃO DOS BENS E SERVIÇOS DO PARQUE NACIONAL DA CHAPADA DOS VEADEIROS E ENTORNO}

\subsection{VALOR E VALORAÇÃO: UM CONSENSO ENTRE O ECONÔMICO E SOCIOAMBIENTAL}

O termo valor e todos os que derivam da sua raiz suscitam grandes discussões, desde o valor das coisas tangíveis, como os bens produzidos pela atividade humana, no processo econômico, até aqueles de natureza intangível, como um serviço ecossistêmico, de grandes proporções, que pode atingir todo o planeta, que é passível, segundo as técnicas de valoração econômico-ambiental, de se lhe atribuir um determinado valor. Segundo Houaiss e Villar (2009), a palavra valor, etimologicamente provém do latim tardio - valore 'id' - cuja sinomínia equivale à serventia, no sentido de utilidade ou utilização proveitosa das coisas. Destaca-se o fato de que, na sua essência, busca-se uma utilidade ou um benefício de alguma coisa, em favor do ser humano. Por extensão, valorar significa apreciar, analisar (algo), a fim de atribuir-Ihe valor ou julgamento. Mais especificamente, em termos de significação econômica, os autores afirmam que valor é "uma medida variável de importância que se atribui a um objeto (bem) ou serviço, que embora condicione o seu preço monetário, frequentemente não lhe é idêntico" (HOUAISS e VILLAR, 2009, p. 1920). Nesse aspecto, subentende-se que algo mais transcende o valor de um bem ou serviço, mesmo que lhes possam ser imputado um valor monetário.

Analisando-se a questão econômica, Faucheux e Noël (1995), apresentam a evolução das atividades humanas, desde Aristóteles até os fisiocratas, com destaque para os modos naturais e não naturais de aquisição de riquezas. No primeiro caso, encontra-se a economia propriamente dita, em que o ser humano, por meio de suas atividades, retirava da natureza o essencial para a sobrevivência da comunidade, cujo princípio baseava-se "num valor de uso concreto e apenas dá lugar a uma acumulação limitada" (FAUCHEUX; NOËL, 1995, p. 30). O segundo caso relaciona-se com a crematística, situada no campo das trocas monetárias, em que a moeda transmuta-se de um instrumento de troca para, a partir do empréstimo a juros, transformar-se numa causa própria, como pontuaram os autores: "o dinheiro deixa de ser um meio (de troca) para se tornar um fim. O desejo de dinheiro substitui o desejo de bens" (FAUCHEUX; NOËL, 1995, p. 31). 
Com os fisiocratas, a noção de valor surgiu com François Quesnay, em um artigo escrito em $1757^{8}$, em que ele distinguiu dois tipos de valores: valor venal ou de troca - valeur vénale - e o valor de uso valeur usuelle.

As riquezas são venais ou comerciáveis na medida em que os possuidores podem vendê-las e em que são procuradas por compradores. [...] O preço é o valor venal das riquezas comerciáveis. [...] Os homens necessitam, portanto, de diferentes riquezas de uso, e aquelas que eles têm em maior quantidade do que precisam devem servir para proporcionar-Ihes aquelas que lhes faltam e que desejam. [...] O valor de uso é sempre o mesmo, e sempre mais ou menos interessante para os homens segundo corresponda às suas necessidades ou ao desejo de desfrutá-lo (KUNTZ, 1984, p. 105-106).

Para os fisiocratas o princípio de toda a riqueza vinha da fertilidade da terra, com origem na produção agrícola, e os outros setores da economia, completavam o valor das mercadorias na proporção dos salários pagos aos fabricantes (KUNTZ, 1984), numa ideia implícita de complementação de valores. Outros elementos, como o ar, a água e bens superabundantes e comuns a todas as pessoas não eram passíveis de comercialização. Conforme Kuntz (1984) relatou, eram simplesmente bens e não riquezas, notando-se uma despreocupação com a questão relativa ao ambiente.

Na escola clássica da economia, foi Adam Smith quem desenvolveu a concepção de que toda produção de mercadorias gera valor, por meio do trabalho necessário para sua produção (LEMOS, 2005). Para Smith (1986), esse valor gerado pertencia aos trabalhadores, caso estes possuíssem os seus próprios meios de produção e subsistência. Smith (1986) também utilizou a tipificação "valor de uso" e "valor de troca" para expressar a utilidade de algum objeto e o poder de aquisição de outros bens que aquele objeto pudesse proporcionar. A sua contribuição se registra no tocante à relevância que deu ao fator trabalho no processo de estabelecimento de valor das mercadorias, quando comparado com as oscilações de valores tanto do trigo, quanto da prata, em épocas e locais distintos, como afirmou: "o trabalho, parece evidente, é a única medida universal e precisa do valor, ou o único padrão pelo qual podemos comparar os valores de diferentes mercadorias em qualquer tempo e lugar" (SMITH, 1986, p. 35-36).

Nesse mesmo pensamento, em que o trabalho agregado ao processo produtivo interferia diretamente no valor das mercadorias, Ricardo (1965) estabeleceu uma relação entre o valor relativo dos bens e do uso do fator capital, em especial o capital fixo, "todos os aperfeiçoamentos nas máquinas, ferramentas, edifícios e na obtenção de matérias-primas poupam trabalho e permitem-nos produzir mais facilmente os bens em que se verificou o mencionado aperfeiçoamento; por isso se altera o seu valor" (RICARDO, 1965, p. 57). O trabalho incorporado à produção de mercadorias influenciava em seu 
valor, juntamente com o capital, havendo um compartilhamento dos dois fatores na formação desse valor.

Ricardo (1965, p. 78) propôs o conceito de renda aplicado ao uso da terra, relacionado com a fertilidade desta, "pois a renda é sempre a diferença entre a produção obtida com a utilização de duas quantidades iguais de capital e trabalho". O autor ressaltou que terras férteis possuíam uma produção com valor de troca menor em função de menor dispêndio de trabalho para seu cultivo, ao passo que, as terras de pior qualidade, tinham a sua produção com valor de troca aumentado, porque necessitavam de maior quantidade de trabalho para ser obtida.

Segundo Lemos (2005), Marx valeu-se das proposições de Smith e Ricardo para desenvolver o conceito de valor-trabalho, em que enfatizou o tempo de trabalho socialmente necessário à produção das mercadorias, estabelecendo-se uma relação antagônica na sociedade entre as pessoas que contribuíam para o processo produtivo, uns detentores do capital, e outros, participantes com sua força de trabalho. "Os primeiros, proprietários dos meios de produção, se apropriam do tempo de trabalho, como valor e a mais-valia, originando o lucro" (LEMOS, 2005, p. 43).

Para Marx (2001), o valor de uso de um bem referia-se à sua utilidade, realizando-se com o seu consumo. O valor de troca guardava uma relação quantitativa entre valores de uso de bens de espécies diferentes, na proporção em que se permutavam, passando a ter um valor relativo. Dessa forma, quando no processo de permuta, o valor de uso de um bem se desvanecia, restando-lhe tão somente a proporção do trabalho humano abstrato que foi incorporado na sua produção, evidenciava-se o seu valor de troca, transformado em mercadoria, como assinalou:

As mercadorias, recordemos, só encarnam valor na medida em que são expressões de uma mesma substância social, o trabalho humano; seu valor é portanto, uma realidade apenas social, só podendo manifestar-se, evidentemente, na relação social em que uma mercadoria se troca por outra. Partimos do valor-de-troca ou da relação de troca das mercadorias, para chegar ao valor aí escondido" (MARX, 2001, p. 69).

Enquanto as tendências analisadas até o momento se preocuparam com a produção e as relações daí advindas, e tentavam correlacionar a estas os valores, na economia neoclássica o enfoque passa a ser o indivíduo e seu comportamento. Lemos (2005) afirma que o pensamento neoclássico baseou-se na ideia da utilidade dos bens, buscando a satisfação dos consumidores, ao concretizar "o conceito de valor subjetivo ou de valor-utilidade dos bens" (LEMOS, 2005, p. 44). Ainda, conforme destaca o autor, o mercado assume um papel decisivo na sociedade, em que homem-consumidor (Homo economicus ou Homo mercator) busca maximizar a satisfação de suas necessidades, com um mínimo de gasto. A 
racionalidade atribuída aos agentes econômicos é a solução simplificadora da realidade no mundo neoclássico e serviu para teorizar também, o comportamento das empresas nas esferas de produção e do mercado (LEMOS, 2005).

Para a economia neoclássica, o bem-estar se baseia na preferência dos indivíduos e esta, por sua vez, pode ser estendida à sociedade como um todo. Cada indivíduo tem uma utilidade para um bem qualquer, que lhe gera certa satisfação, correspondente a um determinado valor. Marshall (1985) relaciona o valor de uma coisa, um bem qualquer, com a satisfação de pagar para não se privar deste, "de modo que a satisfação que se obtém com a compra excede geralmente aquela que se priva ao pagar o seu preço, resultando, portanto, da compra de um excedente de satisfação" (MARSHALL, 1985, p. 123). Mueller (2012, p. 236) reforça essa visão utilitarista da análise neoclássica, do "bemestar social como uma função das satisfações (das utilidades) dos indivíduos em sociedade".

Essa linha de pensamento, que associa um valor a ser definido pelas preferências individuais, em termos monetários, revela uma disposição a pagar ou a receber, por um bem ou serviço ambiental, seja para o seu usufruto ou para suportar um dano, remete ao conceito da externalidade. Mueller (2012) aponta que há externalidades quando ações de um agente econômico (produtor ou consumidor) interferem na atividade de outro agente, de forma não intencional, sem haver compensações por aquele que produz o efeito externo àqueles que foram afetados. Nelson e Winter (2005, p. 521) afirmam ser o termo "utilizado para referir-se ao custo ou ao benefício envolvendo efeitos 'secundários' que os produtores (e/ou consumidores) não atenderiam, exceto sob incentivos ou sob controles reguladores - efeitos como a poluição, o barulho, a experiência de trabalho, ou vizinhanças mais seguras".

No caso do meio ambiente, destaca Mueller (2012), uma ação pode ser positiva e provocar a geração de produtos e serviços capazes de ampliar o bem-estar (a sua utilidade) das pessoas, como também pode causar desconforto e mal-estar. Como assinala Seroa da Motta (1997, p. 3), "quando os custos da degradação ecológica não são pagos por aqueles que a geram, estes custos são externalidades para o sistema econômico. Ou seja, custos que afetam terceiros sem a devida compensação". Por esse motivo, os estudiosos da economia neoclássica vêm desenvolvendo métodos e técnicas para atribuir valor, uma forma de valorar esses benefícios e danos. "Embora o uso de recursos ambientais não tenha seu preço reconhecido no mercado, seu valor econômico existe na medida que seu uso altera o nível de produção e consumo (bem-estar) da sociedade" (SEROA DA MOTTA, 1997, p. 2). 
Outra corrente que trata do valor referente aos bens e serviços ambientais, situa-se na perspectiva institucionalista, na qual em vez das preferências individuais, tendo o mercado como exclusivo balizador de valores, a atenção se volta para as instituições. Segundo Amazonas (2002, p. 177), pela economia institucionalista, os valores ambientais são dados "pela dinâmica da institucionalização instrumental de opções e conflitos em torno do progressivo desenvolvimento do conhecimento científico-tecnológico relativo ao ambiente". Amazonas (2009, p. 191) também afirma que as estruturas institucionais, incluso aí o mercado, formam o que se denomina valor instrumental e pode ser "entendido como o que a sociedade como um todo, dentro dos limites de seu grau de conhecimento é capaz de definir como 'sustentável'".

Nesse aspecto, a sociedade deve se organizar, baseada em padrões tecnológicos em constante mudança, com novas interações extramercado e uma abordagem que focaliza as circunstâncias e as demandas que requerem instrumentos de escolha coletiva, cujos gastos e valores estão constantemente sendo reformulados (NELSON e WINTER, 2005). As instituições, que representam a sociedade, formam os valores em processos dinâmicos de interação, constituindo a estrutura dos sistemas socioecológicos, em que as formas de governança e o conhecimento têm um papel relevante, reconhece Ostrom (2007).

Na economia ecológica, conforme destaca Amazonas (2009), várias abordagens esforçam-se em aproximar os ditames da teoria econômica aos do meio ambiente, numa tentativa de estabelecer uma interface econômico-ecológica, na procura de mostrar a importância das relações materiais e energéticas, todavia, não conseguem avançar, como assegura o autor, no percalço de seu "conteúdo valorativo".

Norgaard (2001) faz uma referência à noção de valor que vai além da questão econômica, permeando outros campos como o social, o político, o filosófico, não perdendo de vista a meta da sustentabilidade, em que a geração atual pode atingir um nível máximo de utilidade sem reduzir a utilidade das gerações futuras. As escolhas das pessoas devem ter um caráter moral que congregue diversos valores, nas variadas instâncias da sociedade.

Tais opções morais implicam juízos de valor, mas esses valores não são de índole econômica. Ao contrário, os valores morais propiciam condições operacionais para a economia no seio das quais os valores econômicos vão surgir. (...) Os valores econômicos, tal como se expressam por meio dos mercados, são determinados em conjunção com os valores morais, expressos pela política (NORGAARD, 2001, p. 85). 
Outro modelo que busca correlacionar preceitos econômicos com ecológicos é evidenciado por Amazonas (2009), na teoria do valor-energia, de Howard Odum, em que se analisa o consumo de energia para a formação dos elementos de uma cadeia ecológica. “Assim, o 'valor' de um elemento qualquer na natureza é definido em termos do conteúdo energético que foi necessário ser mobilizado até sua obtenção, ou seja, o conteúdo energético que nele se encontra 'incorporado', a sua energia (emergia = embodied-energy)" (AMAZONAS, 2009, p. 193).

Segundo Andrade e Romeiro (2009), é uma teoria de valor com base em princípios sistêmicos e da termodinâmica, em que a energia solar representa um insumo primordial que alimenta os sistemas ecológico e econômico. Também conhecida como "análise energética", determina o valor das mercadorias mediante unidades de energia solar necessárias para a sua produção.

Assim, o termo valor adquire várias conotações, dependendo do ponto de vista em que se esteja analisando - social, ambiental, cultural, político, econômico. Pearce e Turner (1990) enfatizam que os economistas, por exemplo, concentram-se no valor monetário expresso na preferência de consumo das pessoas. Esse fato deve ser levado em consideração ao se atribuir um determinado valor a um bem ou a um serviço, seja de qual natureza for, com a preocupação de fazer um recorte específico, baseado num dado referencial teórico que consubstancie o procedimento dessa valoração, como afirmaram Pearce e Turner (1990, p. 22), “um objeto dado, então, pode ter um número de valores afixados devido à percepção dos valores captados pelos valorizadores humanos e os diferentes contextos de valoração".

May et al. (1999) corroboram essa ideia ao elucidarem que a crescente integração dos povos via mercados e a tendência de homogeneização cultural colocam frente a frente diversas concepções de valores, desde aqueles ligados às origens de um grupo, aos atuais, extremamente de cunho monetário. "Os valores culturais ou religiosos associados à biodiversidade são particularmente difíceis de atribuir benefício financeiro" (MAY et al, 1999, p. 3).

Em se tratando desse trabalho, pretende-se atingir um escopo de natureza econômica para a questão valorativa, considerando que, conforme expôs Sheng (2001), os valores econômicos são pertinentes a um conjunto maior, os valores sociais, e, numa sociedade, estes abarcam a sua história, cultura, costumes, crenças, disponibilidade de informação, educação e consciência, apontando-Ihe rumos a seguir em direção a uma sustentabilidade, ou o tipo de sociedade que se almeja ter. 
Não obstante, optou-se por uma valoração de um conjunto de bens e serviços ambientais, seguindo os procedimentos da economia neoclássica, de acordo com a preferência das pessoas que desse conjunto fazem uso, por intermédio dos seus custos de viagem.

Amazonas (2009) frisa que mesmo entendendo que não haja mercados específicos para determinados bens ambientais, recomenda esse tipo de valoração baseado nas preferências das pessoas, utilizando mercados de recorrência. O autor afirma que se deva "recorrer aos valores existentes em outros mercados que possuam relação com o bem ambiental em questão" (AMAZONAS, 2009, p. 206). Nesse caso, as pessoas atribuem um valor referente a quanto estão dispostas a gastar com a realização da viagem.

Mueller (2012, p. 393), acrescenta que:

A economia ambiental neoclássica vem desenvolvendo técnicas de valoração cada vez mais sofisticadas para medir em termos monetários esses elementos, e suas aplicações têm sido cada vez mais amplas. A razão para esse afã de converter custos e benefícios ambientais em valores monetários está na necessidade de ter forma de medição uniforme de uma variada gama de aspectos e situações heterogêneos.

Em complemento à discussão desse tema, Mueller (2012) relata ainda casos concretos em que esse tipo de valoração se emprega, como na análise de projetos, considerando seus custos, benefícios socioeconômicos e ambientais; e também como referência, para o sistema judiciário, na estipulação de valores para efeitos de indenizações, em casos de danos ambientais provocados pela atividade humana.

Nesse contexto da economia neoclássica, que foca na utilidade e preferência pessoais, buscar-se-á na capacidade de apreensão das pessoas e na sua vontade ou disponibilidade a pagar, o valor de uso que estas conferem a um conjunto de bens e serviços ambientais, o PNCV, por intermédio do MCV, que será descrito a seguir, incluso na metodologia de valoração ambiental.

\subsection{VALORAÇÃO AMBIENTAL}

Por que valorar? Essa é a indagação de Seroa da Motta (1997) quando trata da valoração econômica dos bens e serviços ambientais, ainda mais que esses, de certa forma, não sejam transacionados diretamente em mercados e nem apresentem uma definição de preço, que se constitui no elemento quantitativo de valor de um bem ou serviço.

Os bens e serviços, de uma forma geral, suprem as necessidades humanas. Para a satisfação de suas necessidades, o ser humano lança mão da ocupação e da exploração do espaço natural, onde busca, 
nas denominadas funções ecossistêmicas, conjunto das constantes interações que existem entre os elementos estruturais de um ecossistema, os benefícios que são gerados a partir dos serviços ecossistêmicos (ANDRADE e ROMEIRO, 2009). Dentre tais serviços destacam-se os de provisão (abastecimento), de regulação, de suporte e culturais, sendo que, nos últimos figuram atividades de lazer, recreação e outros, base do setor turístico, um dos pilares que sustentam o objeto deste estudo.

As funções ecossistêmicas definem-se como os elementos estruturais que dão suporte à biodiversidade, e dela dependem processos vitais importantes para o desenvolvimento e a sobrevivência de todas as espécies de seres vivos, inclusive a humana. A exploração indiscriminada de um ecossistema pode comprometer os serviços oferecidos, afetando também a sua capacidade de recuperar-se de um dano que pode tornar-se irreversível. Para equacionar esses problemas, Romeiro (2006) aponta que mesmo que haja incertezas, estudos que relacionam biodiversidade e economia devem ser levados em conta, para estimar os danos que a atividade humana possa causar. Camphora e May (2006, p. 26) reforçam essa visão e mencionam alguns resultados, a partir da análise socioeconômica na gestão de políticas ambientais, "apesar das limitações dos mecanismos de mercado para atribuir valor financeiro a bens e serviços que careçam de preço".

Sheng (2001) também corrobora essa ideia, ao evidenciar que os valores econômicos, embora estejam enquadrados numa moldura maior de valores, são tomados como referências para as decisões das pessoas, quando assinala conquanto "os valores sociais serem partes dos determinantes fundamentais das atividades humanas, são os valores econômicos, com base nos preços de mercado, que frequentemente ditam quais atividades humanas devem ocorrer na maioria das sociedades" (SHENG, 2001, p. 169).

Em consonância com o que expôs Romeiro (2006), sobre a estimativa de valor da intensidade dos danos que a ação antrópica pode causar ao ambiente, Mueller (2012) justifica a utilização de instrumentos metodológicos utilizados na economia para avaliar esses efeitos. Ele se apoia na tese de que a esses danos deva-se atribuir um valor monetário, pois os mesmos, de alguma maneira, afetam o bem-estar da sociedade e dessa forma gerariam indicadores para subsidiar projetos e políticas voltadas para a gestão ambiental, com o intuito de atenuar, minimizar e/ou até compensar os efeitos de uma degradação no ambiente oriunda das atividades econômicas.

Dessa forma, os métodos de valoração ambiental, especialmente aqueles provenientes da orientação da economia neoclássica, revestem-se de importância e se destacam no papel de atribuir um valor monetário aos danos ambientais ou a um conjunto de bens e serviços ambientais presentes numa 
localidade, um Parque Nacional, por exemplo, que interfiram na qualidade de vida das pessoas que a estes estejam relacionados.

Essa visão do papel da valoração pressupõe que o meio ambiente seja neutro e que o principal resultado de intervenções humanas sobre este é a geração de produtos e serviços capazes de ampliar o bem-estar (e utilidade) dos indivíduos em sociedade. Reconhece-se, entretanto, que essas intervenções também produzem efeitos em termos de desconforto, de mal-estar, causados pela degradação ambiental (MUELLER, 2012, p. 395).

O ambiente atua com certo grau de estabilidade e a ação antrópica é um fator de desequilíbrio. Os danos por sua vez se estendem a toda uma comunidade, na forma de impactos, ocasionando externalidades, como aponta Mueller (2012, p. 395) "- em que os agentes que geram a degradação impõem danos e custos sobre a sociedade como um todo -", sendo esses custos não contabilizados por quem os produziu, porém sendo difundidos socialmente. Assim, a valoração funcionaria não só como instrumento de avaliação desses impactos, como também, indutora da preservação dos recursos naturais.

Por isso, a análise neoclássica vem motivando o desenvolvimento e o emprego de métodos para estimar, em termos monetários, esses custos e danos. $\mathrm{E}$, por motivos semelhantes, é igualmente importante que se achem formas de determinar, também em termos monetários, os efeitos de medidas e ações que objetivem reduzir a degradação ambiental causada pelo funcionamento do sistema econômico (MUELLER, 2012, p. 395).

Seroa da Motta (1997) destaca que o bem-estar das pessoas deve ser levado em consideração ao se analisar a relação custo-benefício, quando da implementação de políticas e ações ambientais, salientando que o bem-estar é a base da teoria microeconômica neoclássica e na qual se baseiam os métodos de valoração ambiental. “Estes métodos propõem justamente essa forma de análise custobenefício, em que valores sociais dos bens e serviços são considerados de forma a refletir variações de bem-estar e não somente seus respectivos valores de mercado" (SEROA DA MOTTA, 1997, p. 2). Nogueira et al. (2000) se posicionam da mesma maneira, ao enfatizar que os valores não devem ter somente o cunho financeiro, expressos monetariamente, é preciso avaliar os impactos econômicos e sociais de um projeto em que se empreenda a valoração, analisar seus benefícios e custos, confrontálos e obter subsídios para uma escolha que considere também a opção social.

Para Pearce e Turner (1990), o processo de valoração de um bem ou serviço ambiental deve gerar um valor expresso monetariamente, no sentido em que revela a preferência das pessoas, indicando a sua disposição a pagar (DAP), tanto para manter ou usufruir de um benefício, quanto para compensar ou cobrir os custos provocados por um dano ambiental, interferindo nas condições de vida das pessoas. 
“A justificativa para a valoração monetária reside na forma de como a moeda é utilizada como unidade de medida para indicar os ganhos e perdas em utilidade e bem-estar" (PEARCE; TURNER, 1990, p. 121).

Neste sentido, o esforço de atribuir valores econômicos para os benefícios ambientais não valorados no mercado deve ser entendido como a busca de parâmetros monetários que expressam o desejo das pessoas pelo usufruto de um benefício ou pela eliminação de um mal associado a modificações no meio ambiente. Portanto, as técnicas de valoração buscam correlacionar o desejo de conservação do meio ambiente com valores monetários. (YOUNG; FAUSTO, 1997, p. 2)

Os autores supracitados afirmam que as técnicas de valoração permitem a construção de instrumentos analíticos para dar suporte a projetos e políticas de desenvolvimento e preservação, facilitando o processo de tomada de decisões na gestão de recursos naturais, em virtude da sua escassez.

Pearce e Turner (1990), quando tratam de aspectos relacionados à política ambiental, fazem a ressalva de que os ganhos dessa valoração não produzem ganho monetário imediato, mas sim na qualidade de vida que proporciona à população, e lamentam o fato de que esses ganhos dificilmente sejam registrados em termos monetários nas contas nacionais, pela própria dificuldade de sua determinação e, assim, os setores econômicos ganhem com esse fato, ao não internalizarem os custos de um dano ambiental.

Existe uma dificuldade de se atribuir um valor aos bens e serviços ambientais de uma localidade qualquer, ainda mais em se tratando de um bem de "caráter público" ${ }^{9}$, como é o caso de uma UC, em que seus benefícios, a exemplo do que afirmaram Pearce e Turner (1990), não podem ser contabilizados na íntegra no ativo das contas de um país. llustrando essa situação, Medeiros et al. (2011, p. 6) relatam sobre as UC.

Elas fornecem direta e/ou indiretamente bens e serviços que satisfazem várias necessidades da sociedade brasileira, inclusive produtivas. No entanto, por se tratar de produtos e serviços em geral de natureza pública, prestados de forma difusa, seu valor não é percebido pelos usuários, que na maior parte dos casos não pagam pelo seu consumo ou uso. Em outras palavras, o papel das unidades de conservação não é facilmente "internalizado" na economia nacional.

Entretanto, a valoração ambiental dos bens e serviços de uma UC torna-se um elemento relevante em seu processo de gestão, pois, segundo Casimiro Filho (1999), esse instrumento possibilita uma reivindicação junto às autoridades administrativas para a formulação de políticas no sentido de minimizar os impactos que possam ocorrer. 
Para Maia e Romeiro (2008), a utilização dos métodos de valoração dos bens e serviços ambientais de uma UC, permite a viabilização de seu uso sustentável. Ademais, associada à questão da política da sustentabilidade, encontram-se aplicações mais práticas desse processo, pois

a valoração monetária da degradação ambiental é fundamental para, num plano mais geral, o processo de tomada de decisão em relação à definição de prioridades de políticas de preservação ambiental e, num plano específico, como elemento imprescindível em processos judiciais de indenizações por danos causados ao ambiente ou desapropriação de propriedades privadas para fins de preservação ambiental. (MAIA; ROMEIRO, 2008, p. 105)

A questão da valoração econômica dos bens e serviços ambientais tem implicação direta com a finitude dos recursos naturais, assevera Ortiz (2003), fato que se constitui num problema econômico e confere ao processo de valoração uma importância primordial, pois além de estimar os custos sociais do uso desses recursos ou da incorporação de seus benefícios, "permite inserir de forma mais realista o meio ambiente nas estratégias de desenvolvimento econômico, sejam estas locais, regionais ou nacionais" (ORTIZ, 2003, p.82).

Todavia, mesmo com a maioria das pessoas não conseguindo atribuir um valor diretamente a um conjunto de bens e serviços ambientais ou a um dano ambiental, existem, como já foi mencionado, metodologias e técnicas para aferir ou fazer uma aproximação desses valores, associando os mesmos a preços, e uma das maneiras de proceder essa verificação é por meio das preferências individuais, utilizando-se preceitos da economia ambiental neoclássica. Para tal, necessário se faz estabelecer uma tipificação desses valores, para, em seguida, relacionar a um método específico para sua determinação, a exemplo da valoração econômica do conjunto de bens e serviços de um Parque Nacional, como disposto no próximo item.

\subsubsection{MÉTODOS E TÉCNICAS DE VALORAÇÃO AMBIENTAL}

A metodologia usual para a avaliação de custos e benefícios ambientais provocados pela atividade econômica provém dos princípios da economia neoclássica, que se baseia no emprego dos preços de mercado e, em não havendo um mercado específico para bens e serviços ambientais, por serem de natureza de bem público (MUELLER, 2012), esses valores são estimados medindo as escolhas pessoais para aqueles. Convém ressaltar, como frisa Ortiz (2003, p. 82), que "o que está recebendo 'valor' não é o meio ambiente ou o recurso ambiental, mas as preferências das pessoas em relação a mudanças de qualidade ou quantidade ofertada de um recurso ambiental". 
A ideia básica é que "o que as pessoas querem" - preferências dos indivíduos deve ser a base de medição do benefício. A maneira mais fácil de identificar essas preferências é ver como as pessoas se comportam quando se apresenta com escolhas entre bens e serviços. É razoável supor que a preferência por algo positivo vai aparecer na forma de uma disposição a pagar por isso. (...) 0 conceito de disposição a pagar (DAP), assim dá um indicador monetário automático das preferências (PEARCE; TURNER, 1990, p. 125).

Essa estimativa a partir da preferência das pessoas, no caso, tratadas como consumidores, reflete os valores econômicos que estes estão dispostos a pagar por uma mudança na provisão ambiental, a despeito do que afirma Seroa da Motta (1997), inserida numa perspectiva maior de uma política de análise custo-benefício - e tratando-se do conjunto de bens e serviços de um Parque Nacional - em que os benefícios incorrem na conservação e na utilização deste pela sociedade, na busca de seu bemestar.

Então, dessa forma, o valor econômico dos bens e serviços ambientais vai estar vinculado ao uso e não-uso que as pessoas fazem dos mesmos, e também nos seus atributos ou características, que apresentam capacidade de gerar satisfação quando do seu usufruto. A literatura lista esses valores e os relaciona ao seu modo de utilização, como disposto a seguir.

Pearce e Turner (1990) identificam os valores como de uso e de não-uso dos bens e serviços ambientais. Os valores de uso expressam a utilização efetiva ou usufruto do bem ou serviço e dele se obtém um benefício, como um pescador, por exemplo, ou quem gosta de contemplar uma paisagem, uma beleza cênica, ou ainda captar uma imagem, por meio de fotografias, filmagens etc. Seroa da Motta (1997) e Young e Fausto (1997) qualificam como uso direto quando uma pessoa utiliza um bem ou serviço atualmente, por meio da extração, de alguma forma de produção ou consumo direto ou outra atividade, como visitação, lazer e recreação.

Para Mueller (2012), esse tipo de valor que se atribui ao ambiente, no caso de uma valoração econômica do conjunto de bens e serviços ambientais, deve levar em consideração as atividades econômicas aí desenvolvidas e as atividades potenciais, quando da decisão de conservação da localidade em questão.

Nessa categoria de valor encontram-se os bens e serviços de uso indireto, em que o benefício atual aparece na forma de uma função ecossistêmica, como a proteção de nascentes pela preservação de uma floresta, que pode estender-se para a regulação do clima ou a conservação dos solos de determinada localidade (SEROA DA MOTTA, 1997; YOUNG e FAUSTO, 1997). Ribemboim (2000) afirma que estes, por sua vez, prestam um serviço intermediário na produção de outros bens e serviços. 
Outra categoria de valor, segundo Pearce e Turner (1990), é a do valor de opção. "É essencialmente uma expressão de preferência, uma disposição a pagar para a preservação de um ambiente de encontro a alguma probabilidade de que o indivíduo vai fazer uso dele em uma data posterior" (PEARCE e TURNER, 1990, p. 130). Constitui-se na possibilidade de usos futuros, diretos ou indiretos, que podem gerar um benefício tal como a descoberta de um princípio ativo com aplicação medicinal em uma planta ou animal de uma dada região. Ribemboim (2000) equipara o valor de opção ao que denomina de "preço de opção" ("option price") e o relaciona a uma incerteza, em virtude de um consumo futuro, e corrobora com Pearce e Turner (1990, p. 130), quando afirmam que "desde que a incerteza sobre o uso futuro é uma incerteza sobre a disponibilidade, ou oferta, do ambiente, a teoria nos diz que é provável que o valor desta opção seja positivo".

Nogueira et al. (2000) mencionam uma variante dessa categoria ao referirem-se ao valor de quaseopção e destacam o seu papel no contexto de preservação da biodiversidade, pois este representaria "o valor de vetar as opções de uso futuro do recurso, dada uma hipótese de crescente conhecimento científico, técnico, econômico ou social sobre as possibilidades futuras do recurso ambiental sob investigação" (NOGUEIRA et al., 2000, p. 86).

Uma categoria de valor que não decorre do uso, ou mesmo com a opção de se usar ou não o bem ou serviço ambiental, circunscreve-se ao valor de existência, também denominado de valor intrínseco, ao qual Pearce e Turner (1990, p. 130) definiram como sendo "um valor que reside em alguma coisa e que não está relacionado ao ser humano por completo [...] e incluem preocupação, simpatia, respeito aos direitos ou bem-estar dos seres não-humanos". Seroa da Motta (1997), pelo fato do seu não-uso, qualifica-o como um valor passivo e associa com aspectos morais, culturais, éticos e altruísticos das pessoas que se preocupam com as espécies não humanas ou em preservar riquezas ambientais, mesmo que não façam uso atual ou futuro para si. Exemplos que contemplam essas atitudes podem ser vistos nas mobilizações das pessoas para o salvamento de algum ser vivo da extinção ou região ameaçada de destruição, onde estas não terão acesso ou sequer irão usufruir de algum benefício daí oriundo. Conforme destacou Mueller (2012, p. 415), "está associado à manutenção do recurso ambiental em estado préstino" e, embora afete o bem-estar de pessoas por todo o planeta, muitas vezes não resulta em melhorias nas condições das localidades em foco, a não ser que se criem mecanismos de transferência de recursos financeiros para tais regiões.

Pearce e Turner (1990) formulam o Valor Econômico Total, ao englobar o conjunto de valores referentes a um bem ou serviço: 
Valor Econômico Total (VET) = Valor de Uso (VU) + Valor de Opção (VO) + Valor de Existência (VE), sendo que VU = Valor de Uso Direto (VUD) + Valor de Uso Indireto (VUI).

Seroa da Motta (1997), da mesma forma, sintetiza os valores econômicos atribuídos aos serviços e bens ambientais da seguinte maneira, como no Quadro 3 a seguir:

\begin{tabular}{|c|c|c|c|}
\hline \multicolumn{4}{|c|}{ Valor Econômico do Recurso Ambiental ${ }^{10}$} \\
\hline \multicolumn{3}{|c|}{ Valor de Uso } & \multirow{2}{*}{$\begin{array}{c}\text { Valor de Não-Uso } \\
\text { Valor de Existência }\end{array}$} \\
\hline Valor de Uso Direto & Valor de Uso Indireto & Valor de Opção & \\
\hline $\begin{array}{l}\text { bens e serviços } \\
\text { ambientais apropriados } \\
\text { diretamente da } \\
\text { exploração do recurso e } \\
\text { consumidos hoje }\end{array}$ & $\begin{array}{l}\text { bens e serviços ambientais } \\
\text { que são gerados de funções } \\
\text { ecossistêmicas e } \\
\text { apropriados e consumidos } \\
\text { indiretamente hoje }\end{array}$ & $\begin{array}{l}\text { bens e serviços } \\
\text { ambientais de } \\
\text { usos diretos e } \\
\text { indiretos a serem } \\
\text { apropriados e } \\
\text { consumidos no } \\
\text { futuro }\end{array}$ & $\begin{array}{l}\text { valor não associado ao } \\
\text { uso atual ou futuro e } \\
\text { que reflete questões } \\
\text { morais, culturais, } \\
\text { éticas ou altruísticas }\end{array}$ \\
\hline
\end{tabular}

Quadro 3: Taxonomia geral do valor econômico de um bem ou serviço ambiental

Fonte: SEROA DA MOTTA (1997, p.12)

A utilização do valor econômico total do conjunto de bens e serviços ambientais de um determinado local deve ser levada em consideração ao se fazer a análise custo-benefício de qualquer empreendimento, visando a sua sustentabilidade, principalmente sob o ponto de vista do meio ambiente, em que aponta para o fato do mesmo ser viável ou não.

A necessidade de incluir a dimensão ambiental de forma mais abrangente na avaliação de projetos levou a análise custo-benefício a considerar o valor econômico total, com a estimativa do benefício líquido da preservação (da nãoexecução do projeto mantendo o meio ambiente intocado) (MUELLER, 2012, $p$ .413).

O autor menciona que, no caso do ambiente permanecer inalterado, como é o caso de uma UC, há uma prestação de serviços relevantes à sociedade, que se constituem nos benefícios da preservação, que englobam as três categorias de valores, de uso, de opção e de existência, podendo ser reportadas pela expressão que se segue:

$B p=V u+V o+V e$, onde 


\section{Bp = benefícios da preservação,}

$\mathrm{Vu}=$ valor de uso,

Vo = valor de opção, e

Ve = valor de existência.

Assim, para a estimação desses valores, métodos e técnicas foram sendo criados e aprimorados, relacionando-se com cada categoria de valor, em função da natureza ou do objetivo de cada valoração do conjunto de bens e serviços ambientais de uma determinada localidade, como disposta adiante.

Seroa da Motta (1997) tipifica os métodos como de função de produção e de função de demanda. No primeiro conjunto, elenca os métodos de produtividade marginal e de mercados de bens substitutos (reposição, gastos defensivos ou custos evitados e custos de controle). Nesse caso, os valores dos benefícios e custos dos bens e serviços ambientais são balizados por preços de mercado de bens e serviços privados, que servem para estimar o valor econômico do bem ou serviço ambiental analisado e é obtido "pelo produto da quantidade variada do recurso, vezes o seu valor econômico estimado. Por exemplo, a perda de nutrientes do solo causada por desmatamento pode afetar a produtividade agrícola" (SEROA DA MOTTA, 1997, p. 13).

O segundo grupo de métodos da função de demanda relaciona-se com o mercado de bens complementares, que compreende os métodos dos preços hedônicos e do custo de viagem e, mais o método da valoração contingente. Os valores dos bens e serviços ambientais aqui derivam de uma disposição a pagar ou aceitar das pessoas por um serviço ou bem privado complementar ou formalizados em mercados hipotéticos para essa situação, conforme destaca Seroa da Motta (1997, p. 15), em que "estimam-se as variações do nível de bem-estar pelo excesso de satisfação que o consumidor obtém quando paga um preço (ou nada paga) pelo recurso abaixo do que estaria disposto a pagar". Essa variação, de acordo com o autor, denomina-se excedente do consumidor e revela uma disponibilidade a pagar por um bem ou serviço ambiental.

Para Nogueira et al. (2000), não existe uma classificação unânime aceita para os métodos de valoração ambiental, fazendo, portanto, uma explanação de diversas metodologias aplicadas em várias situações, sintetizando-as em aproximações por afinidade de procedimentos. Um grupo, como o Método do Custo de Reposição (MCR) e o Método de Dose-Resposta (MDR), analisa preços de mercado do bem ou serviço ambiental que sofre interferência de um impacto ambiental. Outro grupo faz suas estimativas de valor monetário por intermédio dos preços de mercados substitutos ou 
complementares, destacando-se o Método dos Preços Hedônicos (MPH), o MCV e o Método dos Custos Evitados (MCE). E um terceiro grupo, trabalha com preceitos da captação de preferências das pessoas via mercados hipotéticos, com base em questões simuladas, o Método da Valoração Contingente (MVC).

Alguns autores preferem sistematizar os métodos de valoração de bens e serviços ambientais em diretos e indiretos, como o faz Ortiz (2003). O primeiro grupo de autores busca inferir as preferências individuais por bens ou serviços ambientais diretamente com as pessoas, inquirindo-as sobre suas preferências acerca das propriedades de determinado ambiente.

Neste grupo cita-se a valoração contingente, cujo mote principal é identificar monetariamente as preferências das pessoas com relação a bens e serviços não transacionados em mercados. São criados mercados hipotéticos para o bem e serviço ambiental, e há manifestações individuais sobre a DAP ou a disposição a aceitar (DAA) para manter um ganho ou evitar um dano, provocados por uma interferência no ambiente (ORTIZ, 2003).

Outro método dessa linha é o ranqueamento contingente, em que as pessoas revelam suas preferências por um conjunto de bens e serviços ambientais, organizando-o e atribuindo valores relativos numa escala de importância dentro de um contexto. “A lógica para sua utilização é que as pessoas teriam maior facilidade em expressar suas preferências através da ordenação de bens e serviços usuais nos seus cotidianos do que em termos monetários" (ORTIZ, 2003, p. 97).

O segundo grupo de autores determina os valores do conjunto de bens e serviços ambientais com base no "comportamento das pessoas em mercados relacionados com o ativo ambiental, sejam estes de bens complementares ao consumo do recurso ambiental ou de bens substitutos ao mesmo" (ORTIZ, 2003, p. 85). Neste caso, as pessoas revelam suas disposições a pagar por certo bem ou serviço, demonstrando sua preferência, ao adquirir bens de mercado, relacionada ao uso ou consumo de um bem ou serviço ambiental, como por exemplo, o fato dos gastos incorridos para estar em um local de belezas cênicas, como por exemplo um Parque Nacional. Destacam-se nessa modalidade o MCV e o $\mathrm{MPH}$, e sua principal característica dos métodos é a estimação do valor de uso do bem ou serviço em análise.

Mueller (2012), ao descrever os métodos de valoração ambiental, os distingue, primeiramente, como técnicas de mensuração, que se baseiam nos preços diretos de mercado ou nas mudanças dos níveis de produtividade de um empreendimento, provocadas por alterações ambientais. Dentre tais 
procedimentos, o autor cita o método do custo de oportunidade, o método da mudança de produtividade, o método do capital humano e o método do custo de restauração.

Num segundo grupo, Mueller (2012) destaca as técnicas ou métodos indiretos de valoração, que estabelecem valores monetários aos conjuntos de bens e serviços ambientais de acordo com preços de mercado referentes aos de bens e serviços substitutos ou complementares. Nesse grupo evidenciam-se o MPH e o MCV, este a ser tratado com mais detalhes posteriormente.

A hipótese básica por detrás de seu uso é a de que o comportamento dos agentes econômicos pode revelar o valor implícito de aspectos do meio ambiente. Assim, em alguns casos, uma decomposição de preços em termos de elementos que afetam sua determinação pode servir de base para a atribuição de valores monetários a atributos do meio ambiente que, em si, não são transacionados em mercados (MUELLER, 2012, p. 400).

Ainda, conforme Mueller (2012), um terceiro grupo enquadra as técnicas diretas de valoração, entre as quais prepondera o método de valoração contingente. Tal método perscruta a disposição em pagar ou em receber (indenização) das pessoas, em virtude de um ganho ou perda do usufruto de um conjunto de bens e serviços ambientais, numa dada condição a que tem direito. O mesmo estabelece um mercado hipotético (contingente) de um bem ou serviço ambiental e na sua operacionalização as pessoas são instigadas a manifestar suas preferências sobre as questões propostas, bem como revelar "sua indiferença entre quantias de dinheiro e a disponibilidade do atributo" - bem ou serviço ambiental - (MUELLER, 2012, p. 404).

Assim, esses métodos e técnicas permitem fazer uma estimativa dos diversos valores encerrados no conjunto dos bens e serviços ambientais de uma dada localidade, e cada um especificamente se adequa a uma determinada realidade, como no caso em questão, em que se pretende determinar o valor do conjunto de bens e serviços do Parque Nacional da Chapada dos Veadeiros, por intermédio do MCV, a ser tratado no item a seguir.

\subsubsection{MÉTODO DO CUSTO DE VIAGEM}

Na literatura internacional sobre valoração ambiental, este método é denominado de Travel Cost Method (Método do Custo de Viagem - TCM) e aplica-se a locais abertos à visitação pública em geral, como é o caso de algumas Unidades de Conservação brasileiras, dentre estas se destacando os Parques Nacionais, e mais especificamente o PNCV.

Segundo vários autores afirmaram, entre os quais citam-se Nogueira et al (2000), Haab e McConnell (2002) e Ribemboim (2004), pode-se pleitear que o método seja a técnica mais antiga de que se tem 
conhecimento de valoração de bens e serviços não comercializados em mercado. Proposta pelo economista Hotelling, em meados do século passado, no Oeste dos Estados Unidos, inserido em um contexto envolvendo o uso competitivo de terras públicas com atividades econômicas como a mineração, a extração de madeira e a pecuária, que mais tarde (final dos anos 1950) passou a ser utilizado para atribuir valores para amenidades em áreas de visitação, conforme Haab e McConnell (2002, p. 137).

\begin{abstract}
Em um notório desenvolvimento, o método do custo de viagem foi sugerido por Harold Hotelling, em uma carta inédita, em resposta a funcionários do Departamento do Interior (do Serviço de Parques), solicitando um meio de avaliar os benefícios de terras públicas. Em uma das primeiras aplicações, Clawson computou o custo das taxas de visitação por 100000 pessoas, para os principais parques nacionais nos Estados Unidos.
\end{abstract}

Por esse método é possível aferir o valor econômico que as pessoas estipulam a um determinado conjunto de bens e serviços ambientais de um local que possui atrativos naturais, em função do dispêndio monetário e do tempo gasto, para nessas localidades poderem aproveitar dos seus benefícios e até para sua manutenção e conservação. "Em se utilizando a quantidade de dinheiro e o tempo gasto para se atingir um sítio recreativo e dele se usufruir das atrações e amenidades, é possível se obter uma estimativa das disposições a pagar das pessoas que o freqüentam" (RIBEMBOIM, 2004, p. 3). Uma visita a um sítio recreativo, um Parque Nacional com seus atrativos, revela uma preferência das pessoas associada ao uso e consumo de bens e serviços ambientais. "Cada visita ao lugar de recreação envolve uma transação implícita, na qual o custo total de viajar a esse lugar é o preço que se paga para utilização dos serviços recreativos do parque" (ORTIZ, SEROA DA MOTTA e FERRAZ, 2001, p. 2).

Segundo Maia e Romeiro (2008), os gastos públicos realizados pelos visitantes envolvem despesas que incluem o transporte, hospedagem, alimentação, taxas de entrada nos atrativos, gastos complementares, bem como com o tempo gasto na viagem. Convém ressaltar que na aplicação dessa técnica de valoração, o tempo gasto na viagem deve ser considerado como um custo de oportunidade (PEARCE; TURNER, 1990; MUELLER, 2012) e há uma forte necessidade de correlacionar o "valor tempo" com o custo da viagem, conforme afirmam Haab e McConnell $(2002$, p. 142)

Modelos de demanda por lazer são essencialmente modelos de alocação de tempo e, como tal, deve atender a restrição do tempo do indivíduo e restrição de renda. [...] Se as restrições de tempo e renda podem ser captadas, determina a facilidade com que o tempo pode ser contabilizado corretamente na demanda por recreação. 
Para elucidar essa situação, suponha-se um exemplo bem corriqueiro de uma pessoa que se desloca de Brasília até o PNCV, distrito de São Jorge, em Alto Paraíso de Goiás, para conhecer a sua beleza cênica e suas amenidades, no período de um dia normal de expediente. Sabe-se que as duas localidades distam uma da outra, em média, $250 \mathrm{~km}$ e que o tempo gasto com locomoção dura em torno de seis horas. A referida pessoa tem uma renda mensal de $\mathrm{R} \$ 3.110,00$ e registra as seguintes despesas com o passeio: $R \$ 100,00$ de combustível, $R \$ 25,00$ de alimentação e $R \$ 10,00$ com a taxa do condutor de visitantes no Parque (essa taxa é variável em função do número de pessoas, sendo que um condutor cobra $\mathrm{R} \$ 100,00$ para conduzir um grupo de no máximo 10 pessoas). O passeio por uma das duas trilhas do Parque dura cerca de seis horas. Somando-se os gastos diretos com o passeio, a pessoa desembolsou um total de $\mathrm{R} \$ 135,00$. Porém, ela apresenta um custo adicional de deixar de receber o seu salário correspondente ao dia de trabalho, de $\mathrm{R} \$ 113,20$ (3110: 220 horas $x 8$ horas/dia), que nesse caso representa um custo de oportunidade, equivalente à sua remuneração diária. O custo total da viagem, dessa forma, perfaz uma quantia de $\mathrm{R} \$ 248,20$, que representa a disposição a pagar dessa pessoa, por um dia de usufruto dos benefícios do conjunto de bens e serviços que provêm do Parque Nacional.

Como são consideradas somente a disposição a pagar pelos visitantes ao conjunto de bens e serviços ambientais, "as estimativas econômicas do MCV costumam referir-se apenas a valores de uso direto dos serviços prestados pelo patrimônio natural" (MAIA; ROMEIRO, 2008, p. 107), o valor de uso direto por meio do pagamento efetuado pelos atributos de lazer e recreação do local visitado.

O MCV é um modelo baseado na teoria da função de demanda do consumidor, mais especificamente no modelo de mercados de bens complementares, onde os bens e serviços não possuem preços próprios, mas a visita a um local com atrativos naturais incorre em vários custos diretos e indiretos, como visto anteriormente, em que as pessoas demonstram ou revelam uma DAP para desfrutar dos benefícios aí encontrados (PEARCE e TURNER, 1990; SEROA DA MOTTA, 1997; MIKHAILOVA e BARBOSA, 2004).

Ribemboim (2004) menciona que o método, por sua vez, além de aferir os custos totais dos visitantes de um parque, permite, por meio dessas informações, estabelecer as suas curvas de demanda e inferir o valor do mesmo, e até o quanto esses visitantes estão dispostos a pagar por sua melhoria e conservação, a partir das variações no excedente do consumidor, resultantes do deslocamento de tais curvas. Para Maia e Romeiro (2008, p. 107), isso tem relação com os benefícios gerados por um conjunto de bens e serviços ambientais de um local e permite a identificação das variáveis de estudo. 
O excedente do consumidor é uma medida do bem-estar da população, obtido a partir da diferença entre a disposição a pagar da população por um bem ou serviço e seu custo efetivo de apropriação. Pode ser facilmente calculado quando se conhece a função demanda pelo bem ou serviço que, no caso do MCV, relacionaria a variável dependente, número de visitantes (taxa de visitação), à variável independente, custo de viagem, ao patrimônio natural.

Avaliando-se a abordagem da demanda do consumidor, que é o suporte teórico do MCV, baseandose em Marshall (1985), observa-se que cada consumidor tenha uma certa renda e que o mesmo esteja disposto a pagar um dado preço (P) para obter uma determinada quantidade (Q) de um bem ou serviço, gerando, então, a função de demanda (D), como ilustra a Figura 3 a seguir.

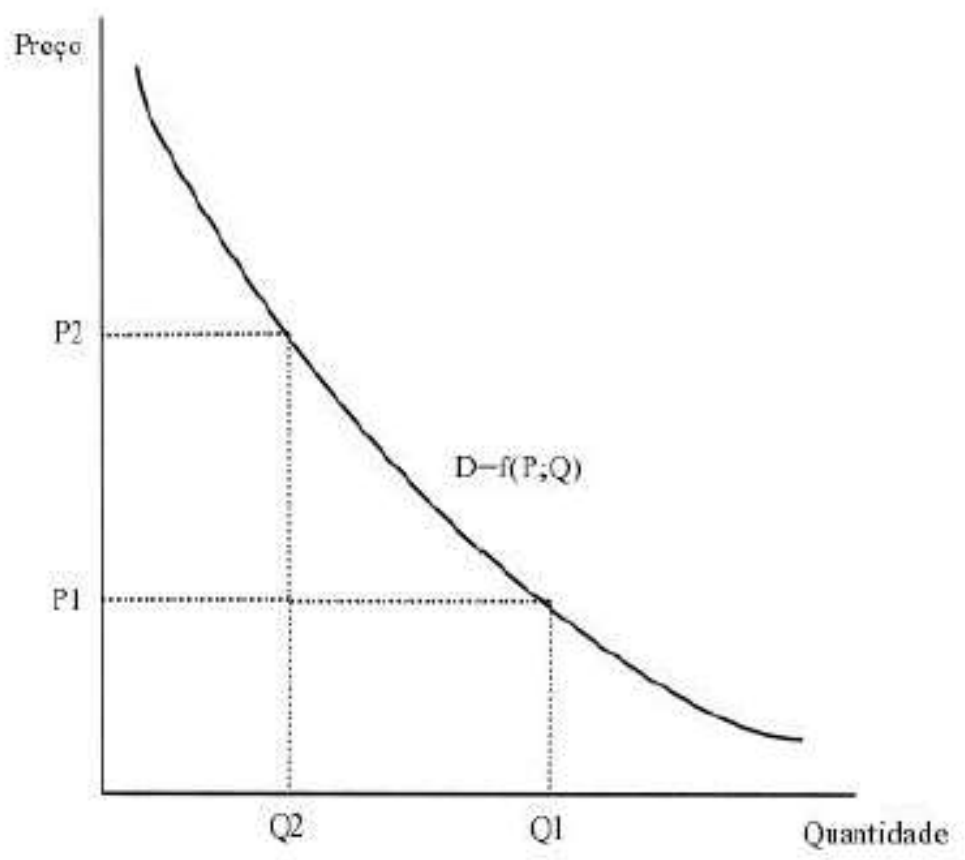

Figura 3: Função de demanda (elaboração própria)

Conforme exposto no gráfico, um consumidor, na possibilidade de uma renda, dispõe-se a adquirir ao preço P1 a quantidade Q1 e, havendo um aumento desse preço, passando para P2, haverá uma tendência de retração da quantidade Q2 a ser adquirida, permanecendo a renda constante. Em tese, supondo um preço próximo de zero, a quantidade a ser consumida tende ao infinito, não havendo dessa forma um limite para a função de demanda (D). Todavia, existe um limite por parte da produção, que é o custo de produção de um bem ou serviço, o qual determina o preço mínimo no mercado. Mas, na hipótese de mais vendedores atuarem nesse mercado e praticarem preços variados, acima desse preço mínimo aceitável, e diversos consumidores se dispuserem a pagar tais preços, o somatório das diferenças dos preços pagos que sobrepuserem o preço mínimo de mercado vai dar origem ao Excedente do Consumidor (EC), ilustrado na Figura 4 à frente. 


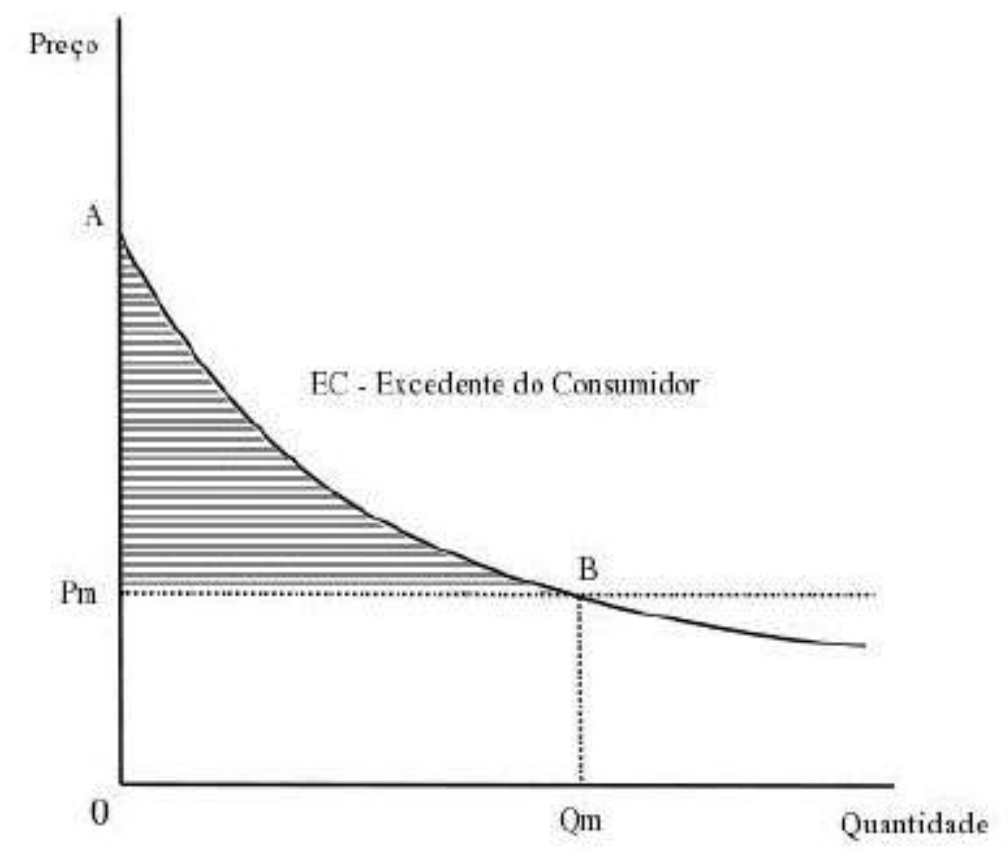

Figura 4: Caracterização do excedente do consumidor (elaboração própria)

Ao se deter na Figura 4, denota-se que a área estabelecida entre os pontos OABQm, equivale ao valor que os consumidores estão dispostos a pagar pelo bem ou serviço. A área situada entre os pontos $\mathrm{OPmBQm}$ refere-se ao valor total pago efetivamente pelos consumidores e a área entre os pontos PmAB, representa a diferença entre as duas áreas, definindo o EC. O ponto Pm indica o preço de mercado e todos os preços que extrapolam o mesmo mostram o quanto os consumidores estariam dispostos a pagar a mais pelo bem ou serviço. Pearce e Turner (1990, p. 126-127) estabelecem uma conexão entre esse modelo marshalliano com os pressupostos referenciais da valoração ambiental, em especial no que tange aos benefícios provindos de um conjunto de bens e serviços ambientais.

Esse princípio da economia neoclássica, que revela a preferência do consumidor, é o elemento que fundamenta o MCV, como afirmam Pearce e Turner (1990, p. 126-127)

A base intuitiva para a medição do benefício monetário é, portanto, bastante simples. As pessoas revelam suas preferências pelas coisas que desejam mostrando sua disposição a pagar por elas. O preço de mercado é o nosso guia inicial para o quanto as pessoas estão dispostas a pagar e, portanto a despesa total com o bem é a nossa primeira aproximação com o benefício recebido. Porém desde que haja pessoas dispostas a pagar mais do que o preço de mercado e, portanto, que irá garantir um excedente de benefício em relação às despesas, a disposição a pagar total irá exceder as despesas totais. $O$ que buscamos na medição do benefício, então, é uma medida de áreas sob as curvas de demanda. 
Para Ribemboim (2004), o MCV é um instrumento que facilita a valoração de um parque, pois é de fácil aplicabilidade, requerendo uma amostragem dos visitantes in loco, principalmente se a viagem é de motivo único, ou seja, direcionada exclusivamente para aquela localidade, ao contrário de uma viagem de múltiplos propósitos, que pode provocar vieses com o truncamento das variáveis. Dessa forma a análise de dados de uma viagem a um local único não sofre interferências de outros atrativos que não estejam relacionados ao motivo principal do passeio, como afirmaram Gürlük e Rehber (2007, p. 1335): "visitantes com um forte interesse em uma recreação baseada na natureza e os aspectos técnicos da ecologia acreditam que alguns parques nacionais são únicos e não possuem substitutos". Haab e McConnell (2002, p. 151) indicam que os trabalhos de campo devem se basear "numa pesquisa de interceptação, onde uma amostra dos usuários do local de recreação é escolhida ao acaso", podendo os dados serem coletados "em um período compreendido em uma temporada ou um ano, ou menos" (HAAB; McCONNELL, p. 158).

Outro fator a ser considerado no MCV é a distância da residência dos visitantes ao local onde está localizado o conjunto de bens e serviços ambientais, os atrativos naturais. Segundo Haab e McConnell (2002, p. 181), o MCV trabalha desde a sua formulação com um modelo zonal, que consiste na formação de círculos traçados, cujos centros coincidem com o local de destino dos visitantes, "uma zona dada, a área entre dois círculos concêntricos, implicará uma distância dada e, portanto, um custo de viagem dado". Os autores mencionam que tais zonas podem ser substituídas por áreas de jurisdições políticas, como estados, países, pela dificuldade de se obter dados demográficos das áreas dos círculos, uma vez que abrangem diversas regiões administrativas. Ribemboim (2000) resolveu essa questão, dividindo as regiões por faixas de distâncias aproximadas, numa escala que abarcava representativamente as regiões de origem dos visitantes, "em círculos concêntricos nem sempre pode ser feita de forma assim tão geométrica, restando, ao invés, a divisão segundo uma logística de acesso ao parque, e com diferentes custos de viagem" (RIBEMBOIM, 2000, p.102). Mikhailova e Barbosa (2004) utilizaram as zonas concêntricas, com distâncias crescentes, adotando custos similares para os visitantes de cada região, ao que denominaram de demanda zonal.

Seroa da Motta (1997, p. 30) adverte, que um dos vieses a serem observados quando se analisa a questão da distância e se correlaciona com o custo da viagem, é o fator tempo, que tem uma relevância nesse tipo de estimativa. "Dada uma determinada distância, custos para certos meios de transporte são mais baixos do que para outros, mas podem requerer tempos de viagens maiores. Da mesma forma, o tempo de visita no local também mantém uma relação direta com a distância". Dessa 
forma, o custo de oportunidade desse tempo agrega-se aos custos incorridos com a viagem, e se torna um elemento importante porque a uma distância maior, dependendo do meio de transporte utilizado, rodoviário por exemplo, há um maior dispêndio de tempo para o percurso e há uma tendência de aumento de tempo de permanência na localidade, aumentando assim as despesas com a viagem, em função dos gastos com hospedagem e alimentação. Outra consideração a ser feita relativa ao transporte é que certos meios de transporte, como o aéreo, diminuem o tempo para vencer grandes distâncias e isso faz tender para uma diminuição do tempo de viagem, e consequentemente com seu custo de oportunidade.

O MCV, segundo Ortiz, Seroa da Motta e Ferraz (2001), deve ser aplicado a uma UC específica, considerando-se as suas peculiaridades, seus atrativos e opções de lazer e recreação que possa oferecer e as características inerentes de seus visitantes, com as suas preferências enquanto consumidores de bens e serviços ambientais, e que lhes atribui um certo valor, que pode, por essa técnica, ser valorado monetariamente. Nesse caso, esses valores podem ser norteadores para medidas de tomadas de decisão na gestão dessas localidades, onde os bens e serviços ambientais como afirma Ribemboim (2000, p. 5), "são geralmente ofertados a preços menores do que deveriam ser e, dificilmente, chegam a cobrir os seus custos de 'produção' (no sentido amplo, envolvendo custos ambientais, sociais etc.)" e também subsidiar políticas públicas voltadas para a área de conservação ambiental.

\subsection{VALORIZAÇÃO TURÍSTICA: PARA ALÉM DO VALOR MONETÁRIO}

Mesmo que possa ser atribuído um valor monetário a um bem ou serviço, o mesmo encerra valores que o transcendem. Para Levin (1997), o valor monetário ou mercantil atribuído a um bem ou serviço, que equivale ao seu preço, pode não expor a magnitude de seu valor, ao afirmar que "a solução do problema do valor enquanto substância social é curso e decurso prático antes de ser discurso teórico. O valor constitui uma essência objetiva, um processo de 'abstração real'” (LEVIN, 1997, p. 2).

Lemos (2005) corrobora esse pensamento e acrescenta ao que expôs Marx (2001), sobre o valor relacionado a uma mercadoria com o trabalho utilizado para produzí-la. O autor afirma que a concepção de valor deve ser mais ampla do que a marxista, "no sentido de que existam relações sociais exógenas àquela que gera a mercadoria" (LEMOS, 2005, p. 169), um bem ou um serviço. 
Em se tratando da questão ambiental, a noção de valor pode variar em função de vários aspectos que extrapolam o econômico e se baliza em elementos de cunho cultural, e até mesmo físicos, dos quais as pessoas retiram recursos para sua sobrevivência, revelando, de certa forma, as suas escolhas.

Indivíduos têm preferências e valoram o meio ambiente, mesmo que não o
façam da maneira que os economistas sugerem. Mais ainda, considerando uma
sociedade específica, o que alguns grupos sociais podem identificar como
positivo, de acordo com seus símbolos religiosos e culturais, para outros grupos
será negativo. Um exemplo é a criação de um novo parque numa área específica
para preservar uma região atingida ou potencialmente atingida pela
depredação humana. Os grupos favoráveis à sua criação atribuirão valores
positivos ao parque, enquanto que os eventuais residentes (por exemplo,
pescadores) da área objeto de preservação atribuirão valores negativos
(NOGUEIRA e MEDEIROS, 1999, p. 77-78).

No caso em estudo, os valores correlacionam uma atividade econômica, o turismo, à questão ambiental. A atividade turística deve ser entendida como um fenômeno de produção social, em que os bens e serviços não têm seu valor encerrado no ato de consumo e permanece sendo processado nas relações sociais (LEMOS, 2005). Assim surge o valor turístico, que abarca as diversas "interações que se ativam no tecido social, tanto da célula de produção turística como nas demais relações sociais envolvidas (atividades econômicas, culturais, religiosas, tecnológicas, etc.), que se imbricam no processo de valorização do valor" (LEMOS, 2005, p. 169).

Segundo o mesmo autor, esse processo de valorização deve ser validado não só pelas pessoas das localidades visitadas, mas também pelos visitantes, conferindo o chancelamento do atrativo turístico. "É preciso que a comunidade valide a configuração de seus valores locais como valores turísticos, e que os turistas experimentem os elementos que constituem e os validem" (LEMOS, 2005, p. 172), atribuindo aos bens e serviços dos locais visitados o seu valor.

Por sua vez as comunidades devem atuar coletivamente para manter a sua atratividade turística, seja no aspecto socioeconômico como ambiental, por intermédio de seu capital social. Lemos (2005) assegura que o trabalho cooperativo demanda mais tempo e esforço de coordenação, mas pode ser o que mais se aproxima de um modelo de atividade turística sustentável.

Pelo lado do turista a validação do valor se manifesta em seu comportamento. "Ao mesmo tempo em que o turista busca valores distintos de seu padrão, mantém como referência o seu padrão" (LEMOS, 2005 , p. 191). Os turistas intentam conhecer outras culturas, visando experienciar a interação com outros grupos sociais e/ou ambientes. 
Swarbrooke e Horner (2002), ao analisarem o comportamento dos consumidores em práticas turísticas relacionaram algumas linhas que norteiam as motivações das pessoas a se deslocarem para um local com certo atrativo, definindo uma tipologia das motivações composta dos seguintes fatores, com suas respectivas atividades.

Físicos: relaxamento; banho de sol; exercício e saúde; sexo.

Emocionais: nostalgia; romance; aventura; escapismo; fantasia; busca de alimento espiritual.

Pessoais: visitar amigos e parentes; fazer novos amigos; necessidade de satisfazer outras pessoas; fazer economia, em caso de rendimentos reduzidos.

Desenvolvimento pessoal: aumentar conhecimento; aprender algo novo.

Status: exclusividade; fator moda; fazer um bom negócio; oportunidades de gastar de maneira ostensiva.

Culturais: visitas a lugares de interesses; vivência de outras culturas. (SWARBROOKE e HORNER, 2002, p. 86).

Esses elementos relacionados por Swarbrooke e Horner (2002) foram agrupados e concatenados em um modelo denominado de Leisure Motivation Scale (Escala Motivacional do Lazer) proposto por Mounir G. Ragheb e Jacob G. Beard, em 1983, no qual se basearam vários estudos de motivação turística. Conforme o modelo, os fatores motivacionais se dividem nos seguintes componentes.

(a) O componente intelectual, que determina até que ponto os indivíduos são incentivados a práticas de lazer envolvendo atividades mentais como aprender, explorar, descobrir, pensar ou imaginar.

(b) O componente social, que determina até que ponto os indivíduos participam de atividades de lazer por razões sociais. Este componente inclui duas necessidades básicas, a de amizade e a de relações interpessoais, a segunda sendo a necessidade da estima de outras pessoas.

(c) O componente domínio-competência, que determina até que ponto os indivíduos se envolvem em atividades de lazer para alcançar, dominar, desafiar e competir. As atividades costumam ser de natureza física.

(d) O componente estímulo-escapismo, que determina o desejo de fugir a situações de vida excessivamente estimulantes. É a necessidade que alguns indivíduos têm de evitar o contato social, buscar a solidão e situações de calmaria; para outros, é a busca do descanso e do espairecimento (SWARBROOKE e HORNER, 2002, p. 87).

Esse modelo indica que a pessoa quando procura um destino turístico, vai ao encalço da satisfação de necessidades que extrapolam as do campo econômico, como maximizar a sua satisfação para um valor monetário a ser gasto. Outros elementos devem ser levados em consideração, como mencionou Lemos (2005, p. 189) “o turismo não se limita a uma relação de consumo, os elementos culturais e as relações sociais interagem com os motivos da viagem, resultando em níveis de satisfação e de 
preferências mais complexos". Dessa forma, esse trabalho preocupou-se em analisar não só a questão econômica do valor, mas os aspectos que permeiam os elementos socioculturais e ambientais das pessoas que constituem o cotidiano do PNCV.

Silva $(2005$, p. 42) corrobora esse pensamento, em que a pessoa quando se desloca para uma localidade turística alia bem-estar com valores extra-econômicos, indicando certos valores decorrentes da atividade: "o turismo é um caminho para a busca da qualidade de vida que valoriza novos conhecimentos, auto-reflexão, oportunidades de interação e equilíbrio com meio ambiente".

Para Casemiro Filho (1999), uma pessoa quando visita um parque ecológico depara-se com alguns valores aí presentes, em função de suas amenidades, beleza cênica e outros bens e serviços que possa apresentar e oferecer ao visitante. Pearce e Turner (1990) relaciona esses valores ao tipo de uso que as pessoas fazem desses bens e serviços, se diretamente ou indiretamente, se de imediato ou no futuro, representando uma opção de o fazê-lo e, de não uso, ligado ao fato do existir, do bem ou serviço, ou até mesmo de um ser vivo.

Por essa linha de pensamento do uso ou não uso de um bem ou serviço de Pearce e Turner (1990), Casemiro Filho (1999, p. 54) aponta que "o valor de um bem ou serviço ambiental é entendido como a expressão monetária dos benefícios obtidos de sua provisão do ponto de vista pessoal de cada indivíduo". Relativo aos bens e serviços que um parque ecológico pode prover, designados como amenidades, o autor relacionou os seguintes valores, com base em Pearce e Turner (1990).

Valor de uso: refere-se ao valor atribuído pelos indivíduos pela participação numa determinada atividade, isto é, pelo uso atual da amenidade ambiental. $[\ldots]$

Valor de opção: diz respeito à disposição a pagar dos indivíduos para conservar um determinado recurso ou amenidade ambiental que poderá ser usado no futuro. $[\ldots]$

Valor de existência: quando os indivíduos obtêm benefícios pelo simples conhecimento de que determinada amenidade ambiental ou certa espécie existe, sem que haja a intenção de apreciá-las ou usá-las de alguma forma (CASEMIRO FILHO, 1999, p. 54-55).

Assim, buscou-se uma referência de valores que os turistas atribuíram ao PNCV, em função dos gastos que tiveram para a realização do passeio, inferindo que, as despesas, ou os valores monetários despendidos são aqueles valores que os visitantes correlacionaram com o usufruto dos bens e serviços que o Parque oferece, revelando o seu valor de uso direto. 


\subsection{RESULTADOS E DISCUSSÕES}

\subsubsection{PESQUISA PILOTO}

Essa pesquisa foi realizada nos dias 22 e 23 de junho de 2012, cujos objetivos estão listados a seguir:

- testar o questionário de pesquisa (Apêndice B) que foi aplicado em trabalho de campo para a valoração ambiental do PNCV por intermédio do MCV;

- sondar as condições de campo para a pesquisa de campo, tais como os melhores horários de abordagem dos visitantes, os locais mais adequados para as entrevistas, entre outros;

- identificar possíveis falhas na aplicação dos questionários, bem como no transcorrer da pesquisa;

- treinar a realização da parte operacional da pesquisa de campo como parte de um processo de aprendizagem.

Em estudos que envolvem trabalhos de campo, nos quais vão ser desenvolvidos e aplicados técnicas e instrumentos para a coleta de dados de um determinado fenômeno ou evento, é necessário que se proceda a realização de uma pesquisa piloto (ADAMS et al., 2003), com o intuito de verificar in loco todos os detalhes a serem vivenciados pelo pesquisador, quando do desenrolar das atividades e da pesquisa propriamente dita.

Esse procedimento, pesquisa piloto, utilizou-se de uma amostragem não-probabilística, escolhendose aleatoriamente elementos desconhecidos, dentro de um universo de visitantes que chegavam ao PNCV para a visita. Tratou-se de uma amostragem de conveniência, em que o entrevistado foi abordado pelo pesquisador de acordo com a oportunidade de aproximação (DENCKER, 2007).

Primeiramente, a pesquisa foi iniciada no portão de entrada do PNCV, local para onde todos os visitantes afluíam, para a formação de grupos, com seus respectivos condutores e para os devidos registros de entrada. Nesse instante foi feita a abordagem ao acaso das pessoas que aguardavam a formação dos grupos. Segundo Haab e McConnell (2002), para o MCV essa amostragem é a mais recomendada, por ser menos dispendiosa financeiramente do que uma pesquisa sobre a população total, em especial quando uma pequena proporção desta se desloca para a localidade, e também porque aí há a maior probabilidade de se interceptar os visitantes mais interessados no passeio "recreadores ávidos" -, conforme os autores.

Foram aplicados dezesseis questionários, previamente elaborados e padronizados, com dez quesitos de respostas diretas (estimuladas e fechadas), alguns deles admitindo mais de uma resposta e 
especificações complementares. Além dessas, ao final foram lançadas três questões de natureza mais subjetiva (espontâneas e abertas), para captar a percepção do entrevistado a respeito dos valores atribuídos ao passeio. Os questionários foram apresentados aos visitantes por volta de oito horas da manhã, antes do início dos trajetos nas trilhas do PNCV, sendo facultada a resposta ao final do passeio, principalmente para aqueles que o faziam pela primeira vez. Após o passeio, este procedimento foi realizado nas pousadas onde os visitantes estavam hospedados, em restaurantes ou ainda abordados nas vielas do Distrito de São Jorge, ao entardecer. Destes, cinco questionários foram aplicados antes, um durante e dez depois dos percursos, na intenção de captar, além dos custos incorridos com a viagem, as expectativas, as emoções e os "sentimentos" a respeito do passeio.

O responsável técnico pela pesquisa aplicou doze questionários, e quatro foram aplicados por dois estudantes auxiliares ${ }^{11}$ em visita técnica ao PNCV, com o intuito de detectar possíveis vieses de aplicadores não envolvidos diretamente com o desenvolvimento da pesquisa. Esse fato apresentou relevância, pois na aplicação dos questionários para a realização do trabalho final contou-se com a cooperação de colaboradores, em virtude do grande número de questionários a serem aplicados, num curto espaço de tempo.

O tempo de aplicação de cada questionário foi cronometrado para avaliação do desempenho do aplicador-pesquisador e também para uma avaliação do teor das respostas, principalmente as de natureza mais subjetiva.

\subsubsection{RESULTADOS DA PESQUISA PILOTO}

Dos visitantes entrevistados que compareceram ao Distrito de São Jorge, entre 22 e 23 de junho de 2012, com o intuito de visitar o PNCV, 31,25\% tinham procedência da região circunscrita até $500 \mathrm{~km}$ de distância da localidade (Brasília principalmente); 62,5\% provinham de uma faixa de $500 \mathrm{~km}$ até $1500 \mathrm{~km}$ (em maior peso do estado do Rio de Janeiro), e um percentual de 6,25\% de regiões afastadas a mais de $1500 \mathrm{~km}$.

Desses visitantes, $25 \%$ utilizaram o carro próprio como meio de locomoção, 31,25\% fizeram uso de avião e carro alugado, $31,25 \%$ de avião e ônibus, 6,25\% de ônibus e outros 6,25\% de ônibus e carona. Notou-se que os percentuais dos deslocamentos de visitantes com carro próprio e de ônibus coincidiram com os percentuais daqueles que eram oriundos da região de até $500 \mathrm{~km}$ da localidade, sendo este o meio de locomoção mais adequado ao seu transporte. Os percentuais daqueles que utilizaram avião e carro/ônibus coincidiram com os visitantes procedentes da faixa situada entre 
$500 \mathrm{~km}$ e $1500 \mathrm{~km}$, denotando ser essa combinação modal de transporte a mais usual para esse trajeto, a saber que o início do deslocamento terrestre se dava em Brasília, distante em média 250km da localidade.

Dos entrevistados, $56,25 \%$ eram do sexo masculino e $43,75 \%$, do sexo feminino, com idade variando na seguinte proporção: 18,75\% entre 16 e 25 anos, 50,0\% na faixa de 26 e 35 anos, 6,25\% entre 36 e 45 anos e $25,0 \%$ no intervalo de 46 e 60 anos. O grau de escolaridade dos mesmos mostrou que cerca de $75 \%$ possuíam no mínimo uma graduação completa e que $25 \%$ tinham o ensino médio.

Da comparação entre os dois grupos de dados anteriores, pode-se observar que os visitantes, em sua grande maioria, apresentaram idade variando entre 26 e 60 anos, com um grau mais elevado de escolaridade, sendo que não se observou nenhuma pessoa situada na faixa de idade caracterizada como terceira idade, presumindo-se que esse tipo de turismo está vinculado a um perfil de pessoas mais jovens e de meia idade, com um grau mais elevado de escolaridade.

Em relação ao motivo da viagem, praticamente todos os respondentes afirmaram estar fazendo turismo, à exceção de 6,25\%, que não mencionaram essa motivação. Ainda, $12,5 \%$ aludiram à motivação de retiro e reflexão e outros $12,5 \%$ aliaram o passeio ao trabalho. O PNCV foi destacado como motivo principal da viagem por $62,5 \%$ dos entrevistados, a mesma proporção para aqueles que declararam ser esta a primeira visita. Outros $56,25 \%$ dos visitantes afirmaram ser o PNCV um dos componentes de um roteiro de viagens realizado pela Chapada dos Veadeiros, incluindo atrativos particulares no entorno do Parque, no Distrito de São Jorge, em outras localidades no município de Alto Paraíso de Goiás e até no município de Cavalcante. Uma grande maioria desses turistas, 81,25\%\%, revelou já ter visitado outro Parque Nacional ou unidade de conservação da natureza, o que se permitiu perceber que pertencem a um grupo específico do turismo denominado de ecoturistas (BENI, 2002).

Na maioria dos casos, em 87,50\% das oportunidades, esses turistas viajaram acompanhados, sendo os grupos não maiores que quatro pessoas, predominando as duplas em $62,50 \%$ das ocasiões. Os viajantes solitários representaram $12,50 \%$ do total dos entrevistados.

Quanto às ocupações, os visitantes mostraram-se em profissões variadas, em que se sobressaiu o grupo dos bancários, com 18,75\%, dentre outras onze categorias diferentes, sendo que 12,50\% declararam-se desempregados ou sem ocupação oficial. 
Concernente à renda das pessoas que visitam o local, 12,50\% declararam-se sem renda no momento da pesquisa; $18,75 \%$ declararam receber até dois salários mínimos mensais, 25,0\% situaram-se na faixa de dois a cinco salários mínimos mensais; outros 25,0\%, na faixa de cinco a dez salários mínimos mensais e ainda, $18,75 \%$ disseram auferir mais de dez salários mínimos mensais. Do total de visitantes entrevistados, observou-se que mais de $2 / 3$ dos mesmos tinham remuneração superior a dois salários mínimos mensais.

Quanto ao pagamento para usufruto dos bens e serviços ambientais do PNCV, valor monetário referente à taxa do condutor de visitantes, 37,5\% dos visitantes consideraram barata e acessível, $50,0 \%$ mediana e $12,5 \%$ cara e elevada. Nesse aspecto, ponderou-se a questão de um grupo sair completo e cada visitante pagar $\mathrm{R} \$ 10,00$ pelo passeio, ao que atribuiu-se um valor acessível e, à medida em que a possibilidade de formação de um grupo maior fosse diminuindo, esse valor aumentaria, o que levou alguns visitantes a considerar um preço elevado. Fato observado quando, no primeiro dia de pesquisa, três visitantes deixaram de fazer o passeio, por não se dispuserem a pagar um preço equivalente a $R \$ 33,33$ por pessoa para efetuar um dos percursos. Outra constatação foi a de que vários visitantes chegavam ao portão de entrada do PNCV e dispunham-se a aguardar alguns minutos a mais, para a formação de um grupo maior de pessoas ou até fechado, para diminuir o custo do passeio. Também foi observada a entrada de alguns grupos com duas pessoas, denotando uma disposição a pagar um maior preço pelo passeio no Parque.

Nesta pesquisa piloto foi lançada para os visitantes entrevistados uma pergunta sobre a possibilidade do PNCV cobrar uma taxa de entrada, ao que 56,25\% dos respondentes concordaram em pagar um preço por essa entrada, para o passeio, contrastando com $43,75 \%$ das pessoas ouvidas, que foram contra esse procedimento de cobrança. Dos entrevistados, 31,25\% estariam dispostos a pagar até $\mathrm{R} \$ 10,00$ pela entrada, além da taxa do condutor de visitantes; $6,25 \%$ concordariam em pagar até $\mathrm{R} \$ 30,00$ pelo passeio, acrescida da taxa de condução; $12,5 \%$ mostraram desejo de pagar um preço acima de $R \$ 30,00$, somando-se ainda a taxa do condutor, para perfazer um dos percursos nas trilhas e, ainda, $6,25 \%$, não emitiram opinião a respeito do assunto.

Finalizando essa pesquisa piloto, foi solicitado de cada entrevistado que indicasse os valores equivalentes incorridos com a viagem, incluindo-se nestes gastos com transporte, alimentação, hospedagem, despesas com atrativos, aí incluídas as taxas dos condutores do PNCV e em propriedades particulares, com equipamentos, com produtos locais, de artesanato, lembranças e outros, como produtos farmacêuticos, por exemplo. Do total apurado das despesas e calculada a sua média, 
encontrou-se um valor de $\mathrm{R} \$ 2.034,94$ por visitante entrevistado, com um desvio padrão de $\mathrm{R} \$ 1.387,65$ para a amostra, sabendo que o menor valor mencionado foi de $\mathrm{R} \$ 95,00$ e o maior valor de $\mathrm{R} \$ 5.000,00$, para um período médio de cinco dias de permanência no local.

Em relação às questões de natureza subjetiva, com indagações cujas respostas poderiam ser abertas e espontâneas, relacionadas com o passeio no PNCV, buscando o porquê da viagem, respondidas de maneira sintetizada se valeu a pena pagar pelas despesas desse passeio e que valores fazem valer a pena, e que são expressos monetariamente nesses gastos, encontrou-se muitos retornos ligados principalmente aos valores intrínsecos, de existência. São valores cujas mensurações são impossíveis de serem captadas e aferidas pelo MCV, mas que permeiam o universo dos valores monetários que foram atribuídos em virtude das despesas incorridas para a realização do passeio, refletidos ou expressados como um "valor de sentimento", assim qualificado por Sebold e Djalma da Silva (2004).

Dessa forma, ficou subentendido que as experiências fundamentam-se nas emoções que as localidades trazem e ficam registradas nas lembranças de quem as vive, e que, para tal tem um dispêndio, como afirmaram Pérez-Nebra e Torres (2010, p.83): “pressupõe-se que o turismo, para a maior parte das pessoas, seja uma atividade de alto envolvimento, por ser relativo às férias das pessoas (momento de prazer e descanso de trabalho), planejado (em sua maioria) com altos custos financeiros, cognitivo e psicológico".

Assim esses custos, de certa maneira refletiram os valores que as pessoas atribuíram ao conjunto de bens e serviços ambientais que um sítio natural propicia, nesse caso o PNCV, principalmente em função de seus gastos monetários, numa demonstração da sua disponibilidade a pagar para o seu usufruto.

\subsubsection{CONSIDERAÇÕES FINAIS DA PESQUISA PILOTO}

Ao final da realização dessa pesquisa piloto, pôde-se constatar que os objetivos propostos foram atingidos, além de proporcionar uma aproximação maior com a comunidade local, do Distrito de São Jorge, para o apoio logístico e operacional da pesquisa de campo, desenvolvida em julho de 2012.

Quanto ao teste do questionário aplicado aos visitantes, pequenas alterações foram feitas, tais como reagrupamento de quesitos para melhor concatenação das informações, facilitando posteriormente a sua tabulação e análise dos resultados. Um ou outro item foi suprimido, como por exemplo, no quesito 6, um item sobre a motivação da viagem por vontade de outra pessoa, que se mostrou sem efeito no resultado da pesquisa. 
Em relação às condições de campo para a realização da pesquisa, observou-se que a melhor situação era estar a postos no portão do PNCV, por volta de oito horas da manhã, para abordar alguns visitantes na chegada, enquanto aguardavam a formação dos grupos, aplicando alguns questionários e agendando outras aplicações em locais e horários oportunos e convenientes aos turistas, após o passeio. Outra constatação feita foi a de que as entrevistas realizadas no período que antecedia o passeio deveriam ser mais direcionadas, mais rápidas, para não tomar tempo do visitante, ao passo que as que ocorreram após o trajeto foram mais ricas em detalhes de informação, principalmente nas questões subjetivas.

A aplicação desses questionários permitiu a percepção da reação dos entrevistados ante as indagações feitas na sua primeira parte, com respostas de natureza objetiva, para criar uma empatia com o respondente e, na segunda parte, poder obter mais informações subjetivas sobre o passeio. Outro fator importante foi a mensuração do tempo de aplicação dos questionários, transcorrendo em tempo mínimo para tal de cerca de 10 minutos, e outros, com duração de cerca de 40 minutos, que depois de realizada a sua aplicação, evoluíram para uma "boa conversa" sobre o assunto em questão.

Concluindo-se, a realização da pesquisa piloto proporcionou um estágio preparatório para o desenvolvimento do trabalho de campo propriamente dito e notou-se, no transcorrer dos dois dias, uma melhoria no desempenho da aplicação dos questionários, frutos de um auto ajuste, próprio dos processos de aprendizagem.

\subsubsection{PESQUISA DE CAMPO}

Essa pesquisa foi realizada entre os dias 13 e 27 de julho de 2012 e apresentou o seguinte intento:

- aplicar questionário (Apêndice C) junto aos visitantes do PNCV para coletar informações para a aplicação do MCV;

- perscrutar junto aos visitantes os motivos do passeio ao PNCV;

- acompanhar e observar as experiências dos visitantes nos atrativos do PNCV.

Conforme afirmaram Freitas et al. (2000, p.106), “o ambiente natural é a melhor situação para estudar o fenômeno de interesse", para registro dos dados a respeito da viagem dos visitantes do PNCV. O contato inicial com os visitantes foi realizado pela equipe de trabalho no portão de entrada do PNCV, pela manhã (de 8:30 às 11:30), utilizando-se a abordagem de conveniência (DENCKER, 2007), de 
acordo com a sua ordem de chegada ao local e enquanto aguardavam a formação dos grupos para se dirigirem às trilhas, com seus condutores.

Alguns visitantes preferiam não responder os questionários naquele momento, em virtude da formação rápida dos grupos, que de acordo com as normas do PNCV, não devem exceder a 10 pessoas, ou agendaram sua participação para depois do passeio, ali naquele local, ou ainda, nas pousadas e áreas de camping onde estavam hospedados ou alojados, em ocasião oportuna. Foi possível observar uma certa ansiedade em realizar mais rapidamente o passeio, numa forma de aproveitar mais o tempo nos locais de recreação por parte de alguns desses visitantes, os "recreadores ávidos", qualificação utilizada por Haab e McConnell (2002).

As aplicações dos questionários, pelo período da manhã, foram realizadas com um tempo mais rápido, com duração de 10 minutos em média, ao passo que as realizadas após o passeio, apresentavam um tempo mais longo, com mais detalhes, principalmente nos quesitos relativos às motivações e valores inerentes à viagem.

Os resultados apresentados referem-se aos quesitos que tratam da caracterização socioeconômica dos visitantes do PNCV, tais como a região de proveniência; os dados pessoais relativos ao gênero, idade, escolaridade e ocupação; a motivação da viagem; o número de pessoas na mesma, o meio de locomoção utilizado para a realização da viagem, o tempo de duração da viagem; a renda pessoal e familiar, e por fim, o custo da viagem, com a totalização de despesas com transporte, alimentação, atrativos, hospedagem, produtos locais (lembranças, produtos de artesanato, souvenirs, produtos da terra etc.) e outros gastos (como medicamentos, imprevistos etc.).

Para a realização dessa fase da pesquisa de campo foram aplicados 389 questionários, de uma amostragem aleatória, calculada sobre a média do número de visitantes do PNCV (19891 pessoas) dos últimos seis anos antes da realização da pesquisa (Apêndice $D$ ), conforme os números apresentados no Quadro 4 abaixo.

\begin{tabular}{|c|c|c|c|c|c|c|}
\hline Ano & 2006 & 2007 & 2008 & 2009 & 2010 & 2011 \\
\hline Visitantes & 17.441 & 20.173 & 17.407 & 23.104 & 20.617 & 20.607 \\
\hline
\end{tabular}

Quadro 4: Número de visitantes do PNCV - 2006-2011

Fonte: Administração do PNCV (2012). 
Segundo informações da administração do PNCV, em julho de 2012 o Parque recebeu 4714 visitantes, perfazendo um total parcial de 14622 visitantes até aquele momento, no ano.

Dos 389 questionários aplicados junto aos visitantes do PNCV e seu entorno, 16 deles por insuficiência de informações e não permitirem o cálculo do custo de viagem dos respondentes, perfazendo um total de 373 questionários analisados, cujos resultados preliminares serão descritos a seguir.

\subsubsection{ANÁLISE DESCRITIVA DA AMOSTRA}

Dos visitantes do PNCV, relativamente à região de origem da viagem, eles foram considerados provenientes de 3 regiões distintas, parte do "modelo zonal" proposto por Haab e McConnell (2002), que no caso foi adaptado em conjunto de Unidades Federativas (UF) que estivessem dentro de uma área, até uma certa distância da localidade, conforme disposto a seguir, no Quadro 5.

\begin{tabular}{|c|c|c|}
\hline Região & Distância & Localidade \\
\hline I & até $500 \mathrm{~km}$ & GO e DF \\
\hline II & 501 a $1500 \mathrm{~km}$ & BA, ES, MG, MS, MT, RJ, SP \\
\hline III & acima de $1500 \mathrm{~km}$ & $\mathrm{CE}, \mathrm{PA}, \mathrm{PE}, \mathrm{PR}, \mathrm{SC}, \mathrm{RS}$, \\
& & EXTERIOR. \\
\hline
\end{tabular}

Quadro 5: Regiões de origem dos visitantes do PNCV - jul. 2012

Fonte: o autor

Analisando-se a região de procedência dos visitantes, observou-se que 49,33\% eram oriundos da região I; $42,63 \%$ da região II, enquanto que, 8,04\% provinham da região III, notando um equilíbrio entre as regiões I e II, com até 1500 km de distância do local, conforme a Figura 26.

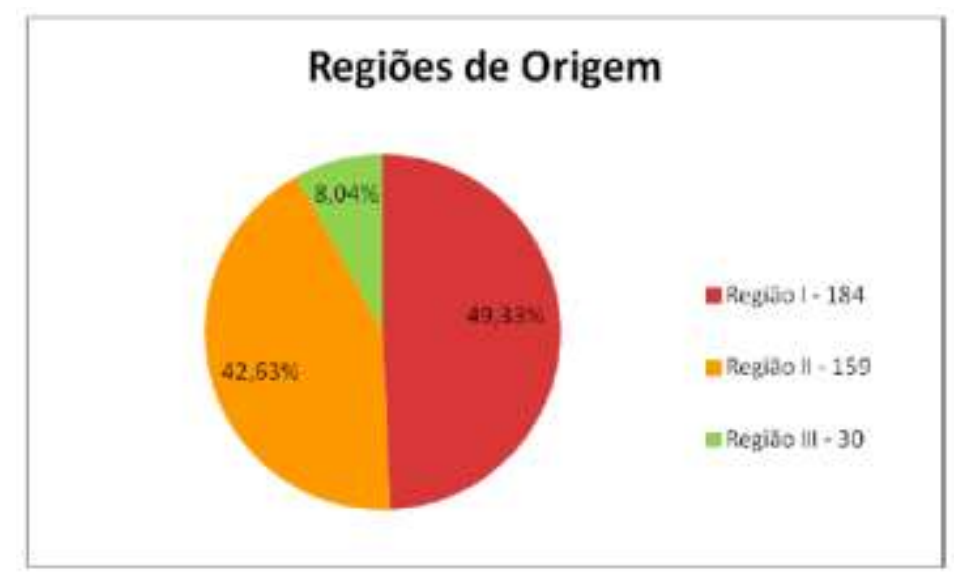

Figura 26: Regiões de procedência dos visitantes do PNCV Fonte: pesquisa de campo 2012 
Entre as UF, destacaram-se o Distrito Federal, com 36,73\% do total de visitantes, cuja distância média não excede a $250 \mathrm{~km}$ do PNCV, fator que facilita o deslocamento das pessoas para a localidade; seguido por São Paulo, com $26,27 \%$ dos casos, perfazendo as duas unidades mais da metade do número dos visitantes do Parque Nacional. O estado de Goiás, que é a UF que sedia o Parque, contribuiu com 12,6\% do total dos visitantes, de acordo com a Figura 27.

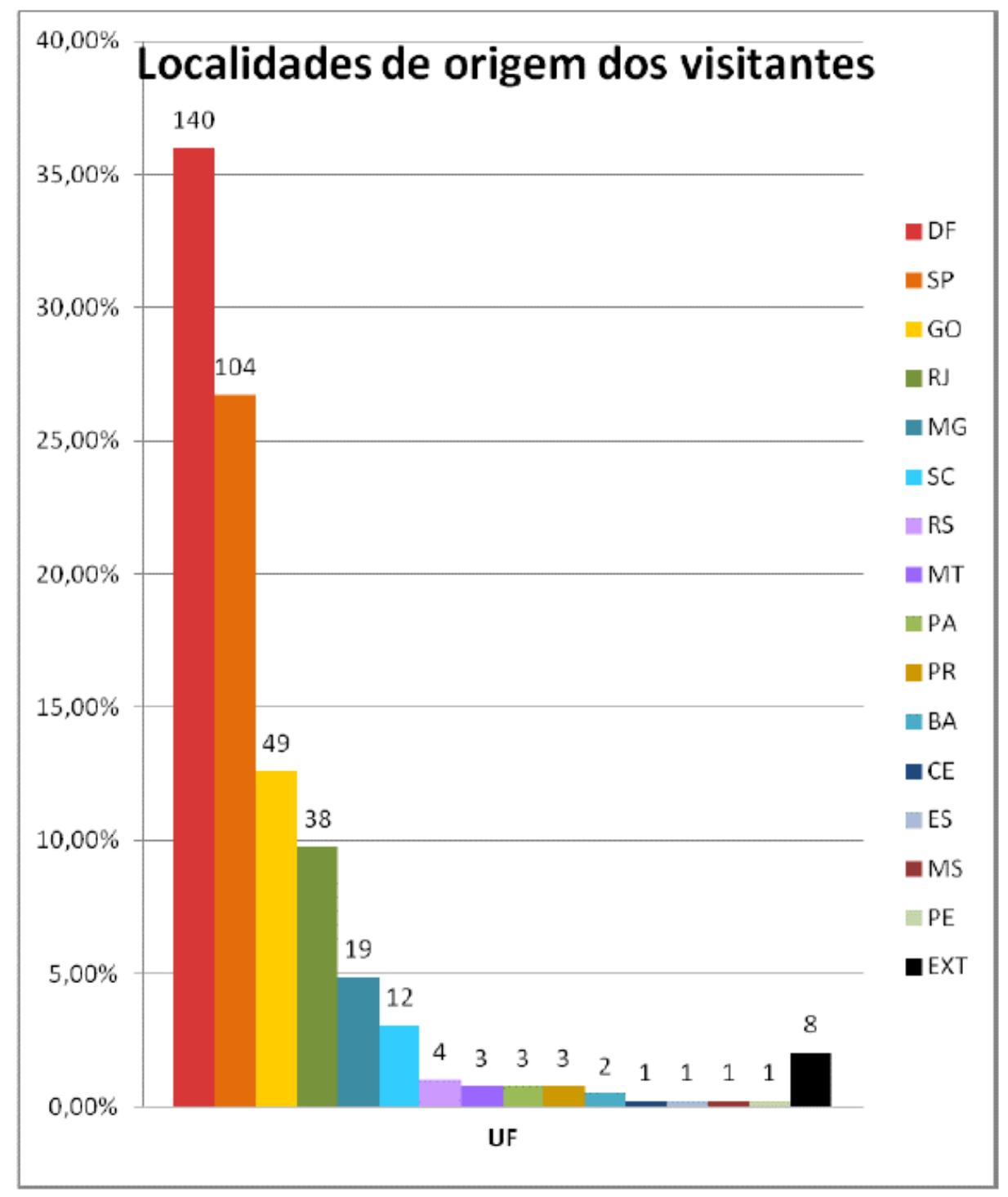

Figura 27: Estados de procedência dos visitantes do PNCV

Fonte: pesquisa de campo 2012

Pela distribuição das UF com seus respectivos visitantes, pode-se notar que todas as regiões administrativas do país contribuíram para formar o universo analisado que visitou o PNCV nesse período, destacando as regiões Centro-Oeste e Sudeste, pela proximidade com o local. Segundo Lemos (2005, p. 187), em que pese o desenvolvimento da infraestrutura e dos meios de transporte, "o 
turismo continua sendo um fenômeno de fronteiras [...] A distância define para a localidade receptora seu mercado geográfico".

Quanto à presença de visitantes provenientes do exterior, observou-se um pequeno número deles, em torno de $1,61 \%$ do total de visitas, sendo que, destas, uma parcela declarou-se brasileira radicada em outro país. De acordo com a administração do PNCV, este período não é o de maior procura por parte de visitantes de outro país, pois tal período coincide com os meses de agosto e setembro.

Em relação ao sexo dos visitantes pesquisados no PNCV, 65,68\% eram do sexo masculino e 34,32\% do sexo feminino. Convém ressaltar que essa proporção não reflete a realidade dos visitantes do Parque, sendo que visualmente pode-se observar uma distribuição mais equânime entre homens e mulheres. O que se constatou em muitos casos, no momento da abordagem das pessoas para responder aos questionários, principalmente se referindo a casais, muitas mulheres passavam a tarefa aos homens, ao saberem do fato de que se tratava de uma pesquisa relacionada aos custos de viagem.

Quando se analisa a faixa etária dos visitantes abordados no PNCV, notou-se que nenhum respondente tinha menos do que 16 anos; que 17,69\% possuiam idade entre 16 e 25 anos; que 41,02\% estavam na faixa entre 26 e 35 anos; que 19,84\% situavam-se no intervalo entre 36 e 45 anos; que 20,38\% se encontravam entre 46 e 60 anos e que apenas 1,07\% estava na faixa de idade acima dos 61 anos, como mostra a Figura 28, a seguir.

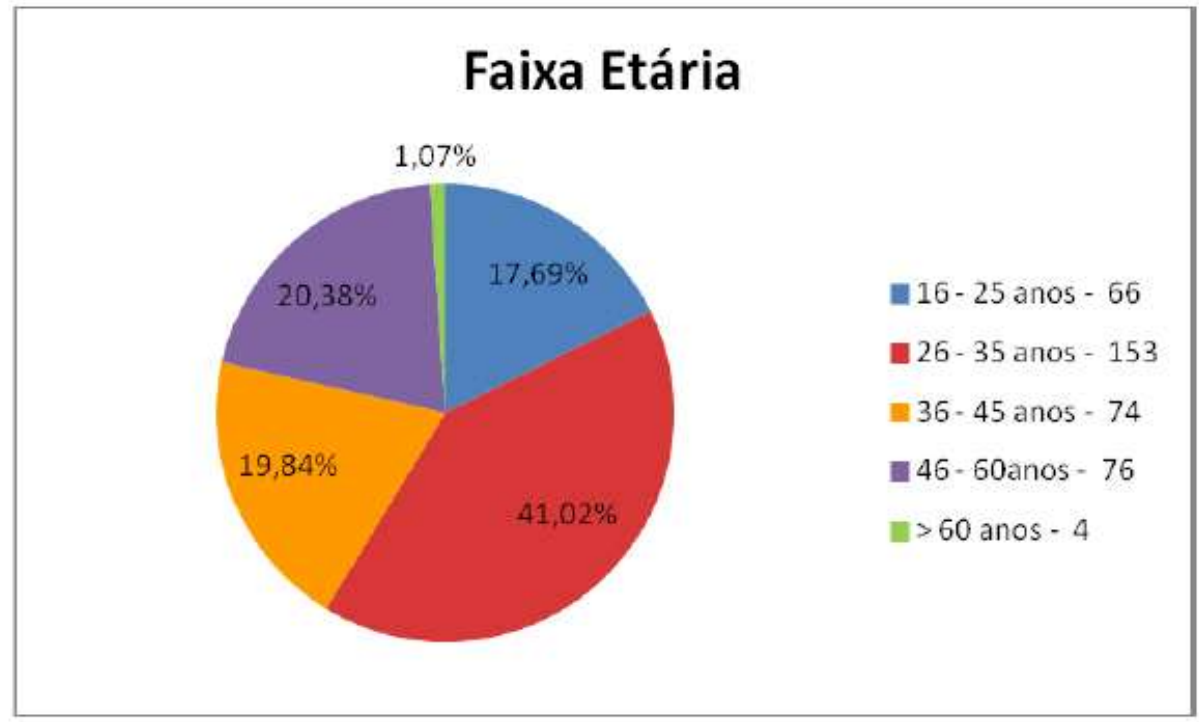

Figura 28: Faixa etária dos visitantes do PNCV

Fonte: pesquisa de campo 2012

Embora nenhum respondente tenha declarado possuir menos de 16 anos, foi possível observar pessoas dessa idade, acompanhadas de seus familiares, sabendo que crianças menores de 5 anos de 
idade não podem fazer o passeio pelas trilhas do PNCV, conforme normas do mesmo estabelecidas para as visitas. Analisando-se os dados da faixa etária, notou-se também que aquelas pessoas mais jovens perfizeram um percentual superior do que as pessoas com maior idade, em virtude do grau de dificuldade para o percurso das trilhas, devido à extensão das mesmas (aproximadamente $10 \mathrm{~km}$ entre ida e volta) e ao terreno acidentado. O percentual de seus percorrentes entre 16 e 45 anos girou em torno de $80 \%$.

Relativo ao nível de escolaridade dos visitantes do PNCV, pode-se constatar que $19,57 \%$ declararam possuir o ensino médio completo; $57,91 \%$, um curso de graduação e $22,52 \%$ do total relataram ter concluído um curso de graduação, e ter cursado ou estar cursando uma pós-graduação, segundo podese visualizar na Figura 29, à frente.

Concernente às áreas de formação dos respondentes e que declararam possuir um curso de graduação, 22,33\% afirmaram que seus estudos apresentavam vínculo ou aproximavam-se do objeto de análise desse trabalho, destacando-se as áreas mais citadas: Geografia, com 14 referências; Economia, com 12 referências; Biologia, com 10 referências; Gestão Ambiental, com 9 referências; Ecologia com 5 referências, Turismo com 4 referências e mais 13 referências relacionadas à área das Ciências da Terra. Desses, uma parcela considerável relatou como motivação da viagem o turismo aliado ao conhecimento específico da área de formação.

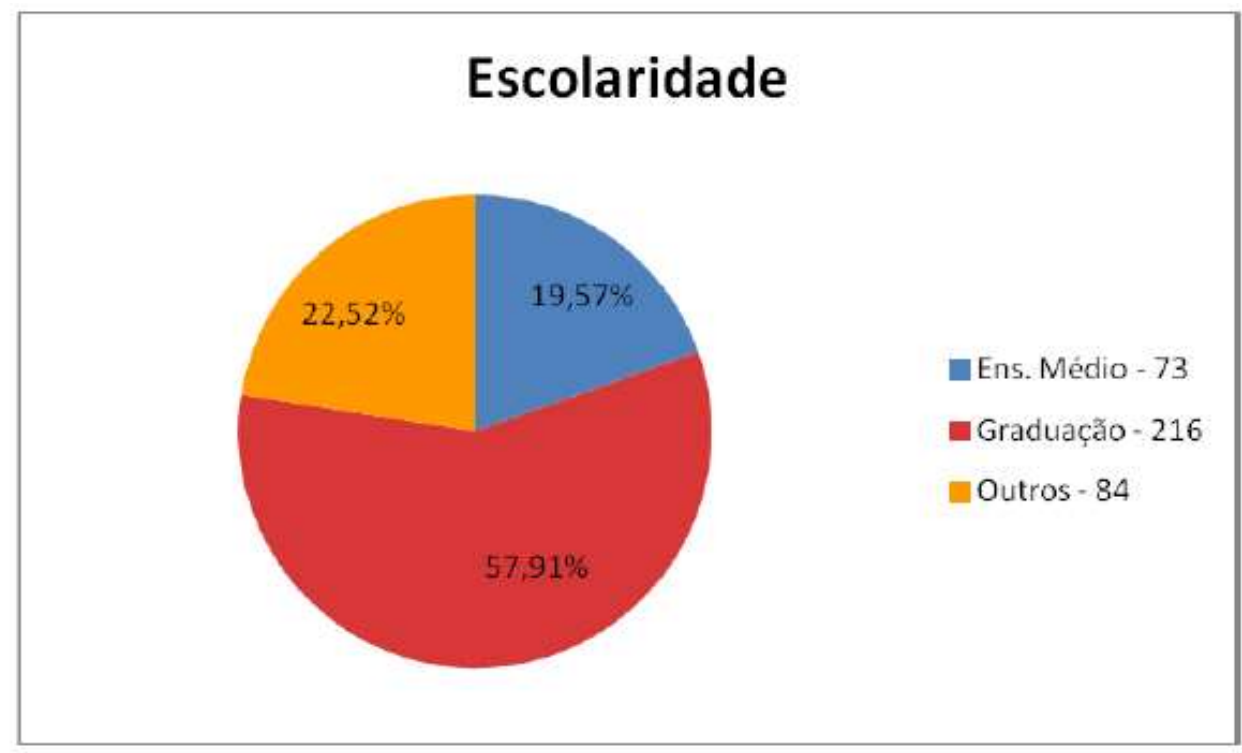

Figura 29: Escolaridade dos visitantes do PNCV Fonte: pesquisa de campo 2012

Quanto ao objetivo da viagem, os visitantes poderiam assinalar as seguintes respostas a seguir: turismo, retiro/reflexão, trabalho e outros, a especificar o motivo. O equivalente a $81,5 \%$ 
mencionaram o turismo como principal indutor da viagem, caracterizando bem a atividade turística como preponderante no PNCV e entorno, enquanto que 4,56\% responderam que o retiro/reflexão correspondia à razão exclusiva da viagem, ao passo que $0,54 \%$ dos respondentes acusaram o trabalho como a finalidade da viagem, e 13,4\% apontaram fatores combinados variados (tendo o turismo como principal fator aliado a outros tais como visita a familiares e amigos, passeio cultural, viagem relacionada com a área de estudo, etc.).

Alusivo à motivação da viagem ao PNCV e seu entorno, analisando-se as respostas dadas a duas perguntas abertas constantes no questionário e comparando-se com a Escala Motivacional de Lazer proposta por Mounir G. Ragheb e Jacob G. Beard (SWARBROOKE e HORNER, 2002), os resultados foram os seguintes: $39,41 \%$ dos entrevistados referiram-se à busca do conhecimento que a região proporciona; $27,35 \%$ destacaram a fuga da agitação dos centros urbanos e busca de tranquilidade no local; 6,17\% mencionaram a importância do convívio social nesse tipo de viagem; 0,8\% relataram isoladamente o ítem domínio- competência, vinculado ao gosto pela aventura e os desafios que um passeio como esse propicia; $24,39 \%$ relacionaram os diversos motivos combinados, sendo que destes mais de 2/3 dos respondentes aliaram o ítem domínio-competência com outro quesito da escala; e $1,88 \%$ preferiram não responder, conforme a Figura 30 a seguir.

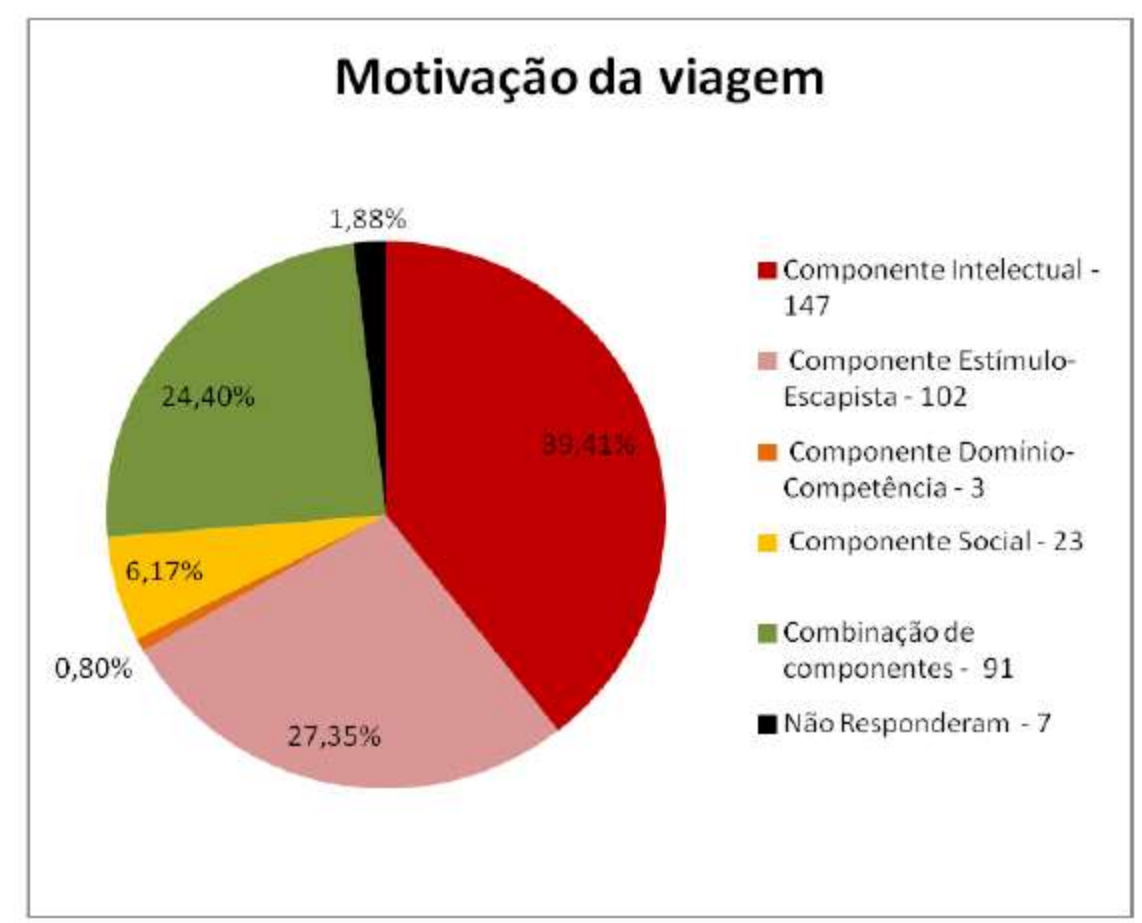

Figura 30: Motivação da viagem dos visitantes do PNCV / Fonte: pesquisa de campo 2012 
Considerando-se a tipificação da viagem, convém esclarecer que duas opções foram apresentadas: ser o PNCV o principal indutor da viagem ou fazer parte de um roteiro turístico. Esse roteiro poderia, num primeiro instante, incluir o Distrito de São Jorge e seu entorno; num segundo, englobar a Chapada dos Veadeiros, principalmente os municípios de Alto Paraíso e Cavalcante e, num terceiro, se estender a outras localidades de Goiás e até outros estados. Nesse aspecto, 33,78\% dos visitantes afirmaram ser o PNCV o principal motivo da viagem, enquanto que $65,15 \%$ atrelaram a visita ao Parque Nacional a outras localidades, na maior parte das vezes aos atrativos de seu entorno, nas proximidades do Distrito de São Jorge. Isso mostra que os visitantes já descobriram os atrativos fora do Parque. Ainda 1,07\% dos visitantes não responderam a esses quesitos.

Com relação ao fato de ser essa viagem a primeira a ser realizada pelos visitantes ao PNCV, 66,22\% dos respondentes disseram que sim, marcando a viagem como a primeira no Parque, em contraste com $33,24 \%$ que responderam já tê-lo visitado em outras oportunidades, enquanto que $0,54 \%$ deixou de responder essa questão. $\mathrm{O}$ fato dos visitantes responderem em maior quantidade ser a primeira viagem demonstra que o PNCV continua atraindo novos visitantes.

Respectiva à visitação a outras UC dessa natureza, sejam nacionais ou estaduais, 81,50\% afirmaram já ter tido a oportunidade de conhecer outras similares, como os Parques Nacionais da Chapada Diamantina (BA) e da Chapada dos Guimarães (MT), entre outros, contrastando com 18,50\%, que apontaram não ter visitado qualquer outro tipo de UC.

Esse aspecto reforça e mostra o perfil do visitante que se dirige ao PNCV, caracterizando-o como ecoturista, a exemplo do que qualificou Beni (2002), aquele tipo de turista que frequenta ou cujo destino são as UC, dentre estas, os Parques Nacionais.

Em relação ao fato de como os visitantes do PNCV estavam viajando, sozinhos ou acompanhados, com a família ou com os amigos: $12,60 \%$ dos respondentes relataram estar realizando a viagem individualmente; enquanto que 31,37\% afirmaram estar em viagem acompanhados de seus cônjuges ou companheiros(as); já os visitantes que estavam viajando em família ou grupos familiares representaram 27,35\%; os que viajaram em grupos de amigos ou em excursões somaram $28,69 \%$, de acordo com a Figura 31. 


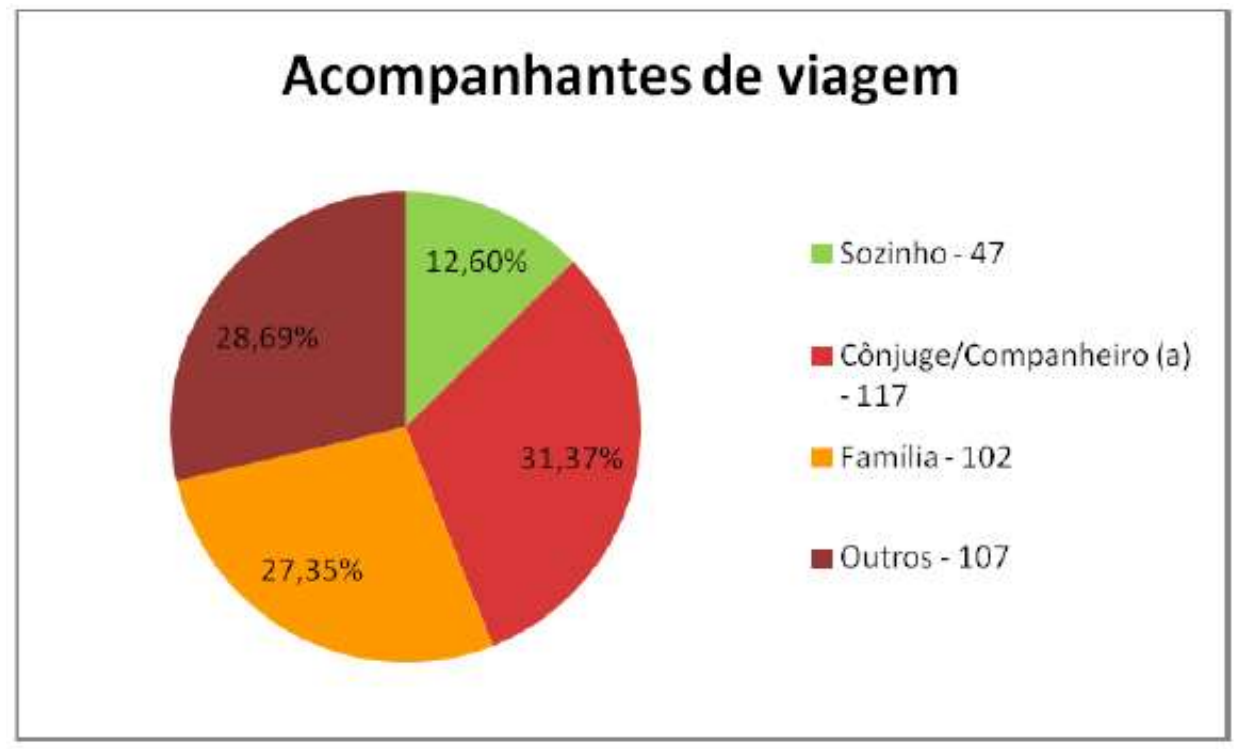

Figura 31: Acompanhantes de viagem dos visitantes do PNCV

Fonte: pesquisa de campo 2012

Analisando a forma de como os visitantes do PNCV estavam viajando, conforme visualizado anteriormente e ponderando em função da totalização de seus acompanhantes de viagem, apurou-se uma média de 3 pessoas por grupo em geral, entre viajantes solitários, casais e grupos familiares ou de amigos, para o total dos visitantes pesquisados. Entre os grupos formados por familiares, a média do número de pessoas viajantes ficou em torno de 3,8 pessoas, e nos grupos de amigos, principalmente, essa média subiu para 4,2 pessoas por grupo.

Em se tratando do meio de locomoção utilizado para o deslocamento dos visitantes até o PNCV, 60,59\% usaram somente o automóvel próprio para atingirem o seu destino, enquanto que 6,97\% o fizeram apenas com a utilização de ônibus. Nesse quesito observou-se a combinação de modais de transporte, em que $25,74 \%$ dos respondentes optaram pelo transporte aéreo agregado ao de carro de aluguel ou serviço de ônibus. Ainda 6,70\% dos visitantes fizeram uso de outros meios de transporte, como motocicletas e de carona, para se locomoverem e chegarem ao PNCV, cujo panorama aparece na Figura 32. 


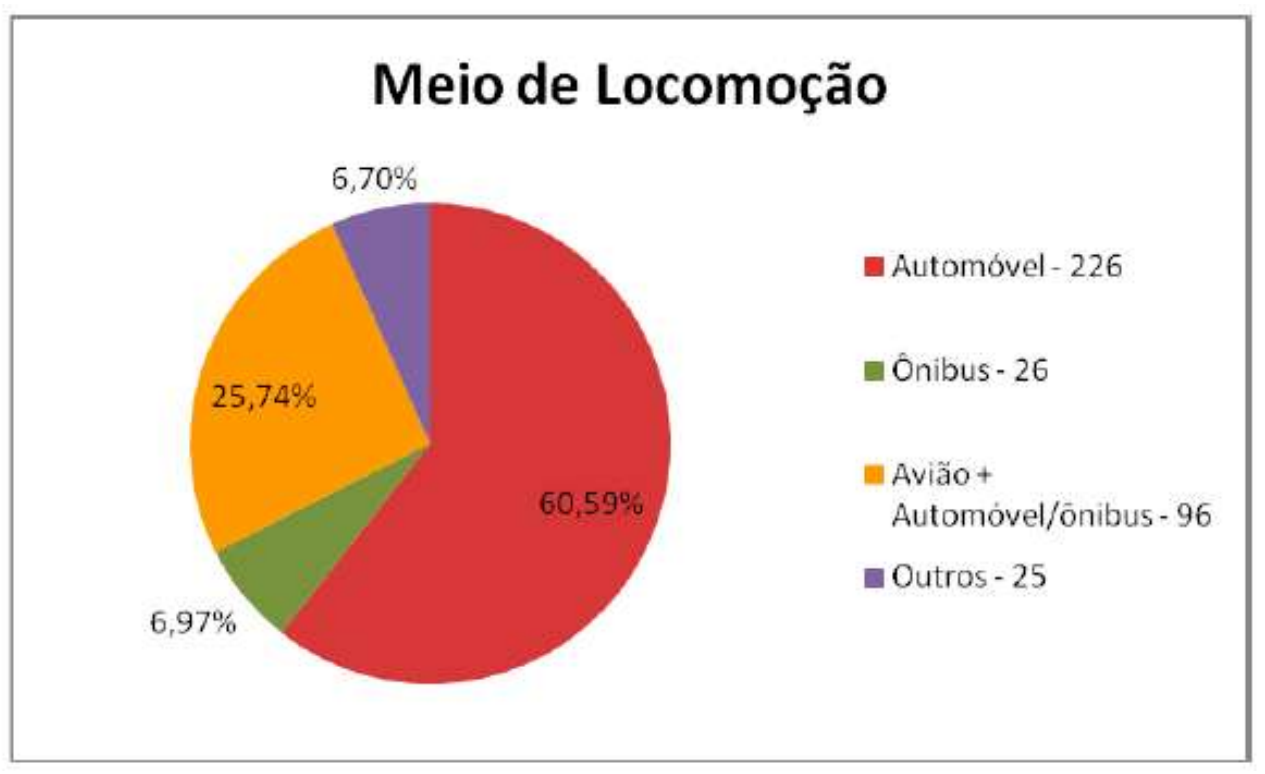

Figura 32: Meio de locomoção dos visitantes do PNCV

Fonte: pesquisa de campo 2012

O percentual elevado do uso de carros como meio de locomoção tem uma ligação proporcional com o percentual de visitantes da região I, do Distrito Federal e do estado de Goiás, mostrando-se ser o meio de locomoção mais adequado para os seus visitantes. Já os visitantes de regiões mais distantes, que não utilizaram o carro em todo o percurso, fizeram uso do avião, com parada em Brasília, optando pelo aluguel de um automóvel ou o serviço de empresas de ônibus, para completar o percurso da viagem.

Relativo ao tempo de viagem e permanência no local, na maioria das vezes nas pousadas e áreas de camping do Distrito de São Jorge, os visitantes do PNCV declararam gastar aproximadamente, em média, 6 dias. Esse elemento é um fator importante a ser considerado, pois no MCV, o custo de oportunidade do tempo das pessoas deve ser computado como um componente do custo de viagem. Quanto ao aspecto da renda pessoal, os visitantes do PNCV e seu entorno se enquadram nas seguintes faixas salariais, baseadas no salário mínimo vigente ( $R \$ 622,00): 5,90 \%$ declararam-se sem renda ou sem uma renda fixa mensal; 8,04\% afirmaram receber uma quantia de até 2 salários mínimos; 27,08\% colocaram-se numa faixa que varia de 2 a 5 salários mínimos; 23,86\% situaram-se num intervalo entre 5 e 10 salários mínimos; $35,12 \%$ dos respondentes declararam auferir uma renda superior a 10 salários mínimos, como dispõe a Figura 33. 


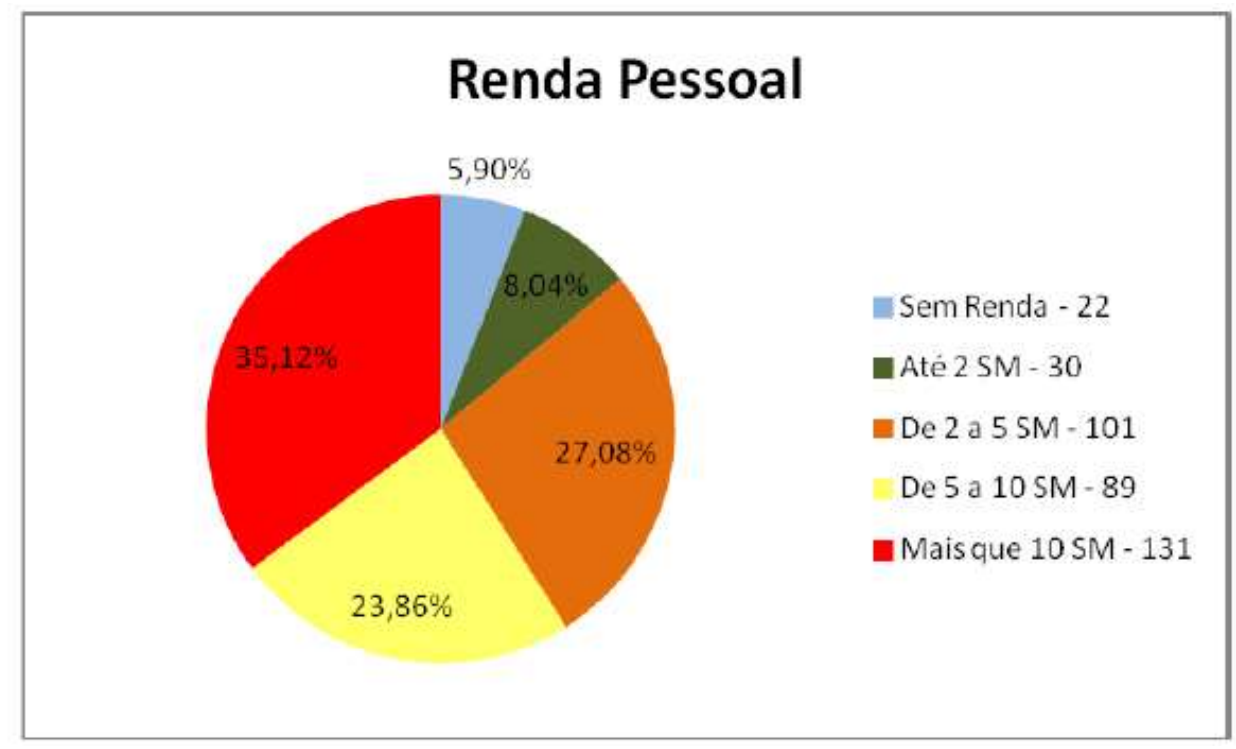

Figura 33: Renda pessoal dos visitantes do PNCV

Fonte: pesquisa de campo 2012

Convém ressaltar que uma boa parte dos respondentes das duas primeiras parcelas, os que se autodenominaram sem renda ou com renda até 2 salários mínimos, declararam-se como estudantes e recebiam bolsas ou mesadas de suas famílias, enquanto que na faixa salarial mais alta, acima de 10 salários mínimos, observou-se uma incidência maior de pessoas que exercem atividades profissionais da iniciativa privada, como empresários, consultores ou de carreiras ocupacionais ligadas à medicina, odontologia e direito, principalmente.

No que se refere à renda familiar, os visitantes do PNCV apresentaram a seguinte distribuição, seguindo o critério das faixas baseadas no salário mínimo vigente ( $R \$ 622,00)$ : 6,43\% situaram-se num intervalo de até 4 salários mínimos; 40,48\% localizaram-se numa faixa intermediária entre 4 e 10 salários mínimos e 53,08\% dispuseram-se num patamar acima de 10 salários mínimos, conforme mostra a Figura 34, a seguir. 


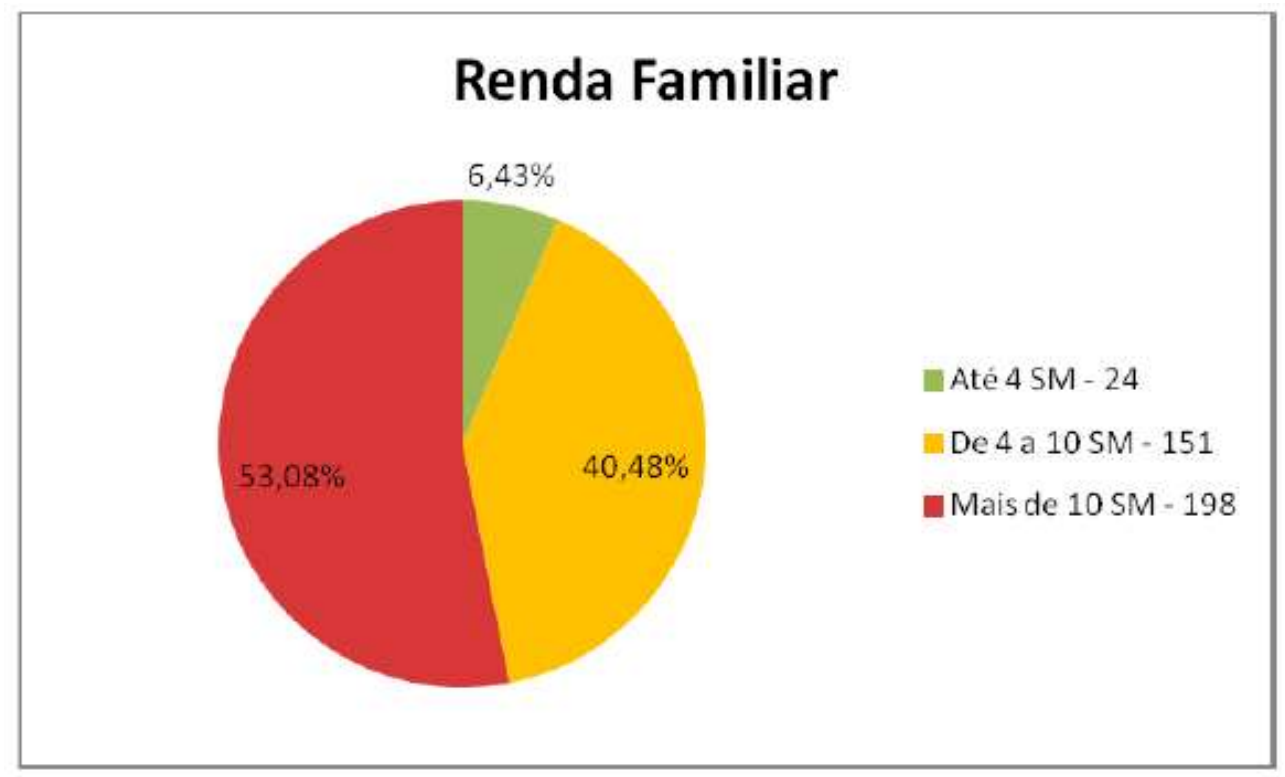

Figura 34: Renda familiar dos visitantes do PNCV

Fonte: pesquisa de campo 2012

Notou-se que, praticamente a metade dos visitantes do PNCV e seu entorno estão situados numa faixa de renda mais elevada, o que demonstra um maior poder aquisitivo das pessoas que praticam o ecoturismo e se destinam a sítios naturais para usufruir dos seus benefícios.

A entrada no PNCV é gratuita, porém até a data da pesquisa exigia-se o acompanhamento obrigatório de condutores de visitantes. Inquiridos sobre esse valor, $35,39 \%$ o consideraram barato; $55,50 \%$ mediano; 7,5\% caro e 1,61\% não responderam ao quesito.

Além desse valor foi indagado aos visitantes sobre uma disposição a pagar por um valor que representasse uma taxa de ingresso no PNCV, dos quais $51,21 \%$ concordaram com a existência da mesma, numa faixa que variou de $\mathrm{R} \$ 2,00$ a $\mathrm{R} \$ 50,00$. Destes, $48,79 \%$ do total dos respondentes estipularam um valor monetário para a entrada no Parque, atingindo um valor médio equivalente a $\mathrm{R} \$ 10,65$, que se somaria ao valor cobrado pelos condutores de visitantes para a realização do passeio.

\subsubsection{ANÁLISE ESTATÍ́STICA E DISCUSSÕES}

Para análise dos resultados das informações que foram extraídas dos questionários aplicados aos visitantes, procedeu-se uma comparação entre as variáveis número de pessoas (NP), tempo de viagem $(T)$, custo de viagem $(C V)$, região de origem $(R)$, meio de locomoção $(M L)$, acompanhantes de viagem (V), renda pessoal (RP), renda familiar (RF), taxa de entrada no Parque (TX), disponibilidade a pagar (DAP), dentre outras, no intuito de verificar a influência das mesmas na variação do custo de viagem, 
que se relaciona diretamente com os valores que os visitantes atribuem ao conjunto de bens e serviços do PNCV 12 .

Na comparação da variável região de origem $(R)$ com as demais variáveis apresentou significância com relação aos gastos na viagem a variável meio de locomoção (ML), conforme se pode visualizar na Tabela 1 abaixo:

Tabela 1: Comparação da variável região de origem em relação à variável ML.

\begin{tabular}{|c|c|c|c|c|c|c|}
\hline \multirow{2}{*}{ Região de origem } & \multicolumn{2}{|c|}{ até $500 \mathrm{~km}$} & \multicolumn{2}{|c|}{501 até $1500 \mathrm{~km}$} & \multicolumn{2}{c|}{$>1500 \mathrm{~km}$} \\
\hline Meio de locomoção & $\mathrm{n}$ & $\%$ & $\mathrm{n}$ & $\%$ & $\mathrm{n}$ & $\%$ \\
\hline automóvel & 170 & 92,4 & 53 & 33,3 & 3 & 10,0 \\
\hline ônibus & 10 & 5,4 & 15 & 9,4 & 0 & 0,0 \\
\hline avião & 0 & 0,0 & 73 & 45,9 & 23 & 76,7 \\
\hline outros & 4 & 2,2 & 18 & 11,3 & 4 & 13,3 \\
\hline Total & 184 & 100,0 & 159 & 100,0 & 30 & 100,0 \\
\hline
\end{tabular}

Fonte: elaboração própria

Na região I, devido a proximidade com o PNCV, o deslocamento dos visitantes se dá em sua grande maioria por automóvel $(92,4 \%)$, fato que faz com que o custo da viagem tenda a diminuir em função desse modal de transporte implicar em gastos menores.

Para a região II, houve uma divisão entre os modais de transporte dos visitantes, sendo que o deslocamento por automóvel (33,3\%) e por avião e automóvel/ônibus (45,9\%), representaram os maiores percentuais, havendo um aumento nos custos da viagem, por influência do custo maior do transporte aéreo.

Observando a região III, o percentual do deslocamento por via aérea é maior (76,7\%), o que indica uma tendência a um aumento do custo de viagem. É conveniente esclarecer que o deslocamento aéreo se dá até Brasília, e o restante da viagem é completado pelo aluguel de automóveis ou por ônibus.

Analisando-se a variável idade (I) quando comparada com as variáveis acompanhantes de viagem (V), renda pessoal (RP), renda familiar (RF), se o Parque deveria cobrar uma taxa de entrada (TX) e a disponibilidade a pagar (DAP) pela entrada no Parque, verificou-se os seguintes resultados, de acordo com a Tabela 2, a seguir: 
Tabela 2: Comparação da variável idade em relação às variáveis $V, R P, R F, T X, D A P$.

\begin{tabular}{|c|c|c|c|c|c|c|c|c|c|c|}
\hline \multirow{2}{*}{ Idade } & \multicolumn{2}{|c|}{$\begin{array}{c}16 \text { e } 25 \\
\text { anos }\end{array}$} & \multicolumn{2}{|c|}{$\begin{array}{c}26 \text { e } 35 \\
\text { anos }\end{array}$} & \multicolumn{2}{|c|}{$\begin{array}{c}36 \text { e } 45 \\
\text { anos }\end{array}$} & \multicolumn{2}{|c|}{$\begin{array}{c}46 \text { e } 60 \\
\text { anos }\end{array}$} & \multicolumn{2}{|c|}{$>61$ anos } \\
\hline & $\mathrm{n}$ & $\%$ & $\mathrm{n}$ & $\%$ & $\mathrm{n}$ & $\%$ & $\mathrm{n}$ & $\%$ & $\mathrm{n}$ & $\%$ \\
\hline \multicolumn{11}{|c|}{ Acompanhantes de viagem } \\
\hline Sozinho & 8 & 13,1 & 24 & 16,2 & 11 & 13,1 & 4 & 5,3 & 0 & 0,0 \\
\hline Cônjuge/companheiro & 17 & 27,9 & 52 & 35,1 & 26 & 31,0 & 20 & 26,7 & 2 & 40,0 \\
\hline Família (filhos / pais) & 8 & 13,1 & 24 & 16,2 & 26 & 31,0 & 42 & 56,0 & 2 & 40,0 \\
\hline Outros & 28 & 45,9 & 48 & 32,4 & 21 & 25,0 & 9 & 12,0 & 1 & 20,0 \\
\hline Total & 61 & 100,0 & 148 & 100,0 & 84 & 100,0 & 75 & 100,0 & 5 & 100,0 \\
\hline \multicolumn{11}{|l|}{ Renda Pessoal (SM) } \\
\hline até $2 \mathrm{SM}$ & 17 & 40,5 & 10 & 6,8 & 2 & 2,4 & 1 & 1,3 & 0 & 0,0 \\
\hline 2 a $5 \mathrm{SM}$ & 17 & 40,5 & 55 & 37,7 & 17 & 20,5 & 11 & 14,7 & 1 & 25,0 \\
\hline 5 a $10 \mathrm{SM}$ & 7 & 16,7 & 42 & 28,8 & 22 & 26,5 & 17 & 22,7 & 1 & 25,0 \\
\hline$>10 \mathrm{SM}$ & 1 & 2,4 & 39 & 26,7 & 42 & 50,6 & 46 & 61,3 & 2 & 50,0 \\
\hline Total & 42 & 100,0 & 146 & 100,0 & 83 & 100,0 & 75 & 100,0 & 4 & 100,0 \\
\hline \multicolumn{11}{|l|}{ Renda Familiar (SM) } \\
\hline até $4 \mathrm{SM}$ & 8 & 13,1 & 13 & 8,8 & 2 & 2,4 & 1 & 1,3 & 0 & 0,0 \\
\hline 4 a $10 \mathrm{SM}$ & 24 & 39,3 & 75 & 50,7 & 28 & 33,3 & 22 & 29,3 & 2 & 40,0 \\
\hline$>10 \mathrm{SM}$ & 29 & 47,5 & 60 & 40,5 & 54 & 64,3 & 52 & 69,3 & 3 & 60,0 \\
\hline Total & 61 & 100,0 & 148 & 100,0 & 84 & 100,0 & 75 & 100,0 & 5 & 100,0 \\
\hline \multicolumn{11}{|c|}{ O Parque deveria cobrar taxa de entrada } \\
\hline $\operatorname{Sim}$ & 18 & 29,5 & 71 & 49,3 & 53 & 63,9 & 44 & 60,3 & 5 & 100,0 \\
\hline Não & 43 & 70,5 & 73 & 50,7 & 30 & 36,1 & 29 & 39,7 & 0 & 0,0 \\
\hline Total & 61 & 100,0 & 144 & 100,0 & 83 & 100,0 & 73 & 100,0 & 5 & 100,0 \\
\hline
\end{tabular}

\section{Disponibilidade a pagar pelo ingresso}

\begin{tabular}{|c|r|r|r|r|r|r|r|r|r|r|}
\hline Não & 45 & 73,8 & 78 & 52,7 & 34 & 40,5 & 34 & 45,3 & 0 & 0,0 \\
\hline Sim & 16 & 26,2 & 70 & 47,3 & 50 & 59,5 & 41 & 54,7 & 5 & 100,0 \\
\hline Total & 61 & 100,0 & 148 & 100,0 & 84 & 100,0 & 75 & 100,0 & 5 & 100,0 \\
\hline
\end{tabular}

Fonte: elaboração própria

Quanto aos acompanhantes de viagem, os visitantes mais jovens, entre as faixas de 16-25 anos, com $45,9 \%$ e de $26-35$ anos, com $32,4 \%$, tenderam a viajar em grupos, buscando hospedagens alternativas, como as áreas de camping, com diárias mais baratas e dividindo as outras despesas, como alimentação, o que pode tornar o custo de viagem mais baixo em relação às pessoas em faixas maiores 
de idade. À época da pesquisa, as diárias de uma área de camping variavam entre $R \$ 10,00$ e $R \$ 20,00$ por pessoa.

Os visitantes com faixas de idade maiores, de $36-45$ anos, com $31,0 \%$, e de $46-60$ anos, com $56,0 \%$, viajaram em família, tendiam a se hospedar em pousadas com diárias mais caras, que variavam entre $R \$ 50,00$ e $R \$ 200,00$ por pessoa, fazendo o custo de viagem aumentar.

Em relação às rendas pessoal e familiar, a tendência era de haver um aumento das mesmas, de acordo com que havia um aumento das faixas de idade, indicando a possibilidade de haver um maior gasto com a viagem, à medida em que as duas variáveis aumentaram.

Quanto à possibilidade de pagamento de uma taxa de entrada no Parque (TX) e uma disponibilidade a pagar por um ingresso (DAP) constatou-se que, à medida em que a faixa de idade ia aumentando, havia um aumento do percentual dos que eram favoráveis a essa cobrança.

Comparando-se a variável escolaridade (E) com as rendas pessoal (RP) e familiar (RF) e também com a possibilidade de cobrança da taxa de entrada no Parque (TX) e a disponibilidade a pagar (DAP) pelos visitantes notou-se o seguinte resultado (Tabela 3).

Tabela 3: Comparação da variável escolaridade em relação às variáveis RP, RF, TX, DAP.

\begin{tabular}{|c|c|r|r|r|r|r|}
\hline \multirow{2}{*}{ Escolaridade } & \multicolumn{2}{|c|}{ Ensino Médio } & \multicolumn{2}{c|}{ Graduação } & \multicolumn{2}{c|}{ Outros } \\
\cline { 2 - 7 } & $\mathrm{n}$ & \multicolumn{1}{|c|}{$\%$} & $\mathrm{n}$ & $\%$ & $\mathrm{n}$ & \multicolumn{1}{|c|}{$\%$} \\
\hline Renda Pessoal (SM) & 18 & 34,0 & 11 & 5,1 & 1 & 1,2 \\
\hline até 2 SM & 21 & 39,6 & 67 & 31,2 & 13 & 15,9 \\
\hline 2 a 5 SM & 6 & 11,3 & 56 & 26,0 & 27 & 32,9 \\
\hline 5 a 10 SM & 8 & 15,1 & 81 & 37,7 & 41 & 50,0 \\
\hline >10 SM & 53 & 100,0 & 215 & 100,0 & 82 & 100,0 \\
\hline Total
\end{tabular}




\begin{tabular}{|c|r|r|r|r|r|r|}
\hline Renda Familiar (SM) \\
\hline até 4 SM & 10 & 13,7 & 12 & 5,6 & 2 & 2,4 \\
\hline 4 a 10 SM & 33 & 45,2 & 90 & 41,7 & 28 & 33,3 \\
\hline >10 SM & 30 & 41,1 & 114 & 52,8 & 54 & 64,3 \\
\hline Total & 73 & 100,0 & 216 & 100,0 & 84 & 100,0 \\
\hline O Parque deveria cobrar taxa de entrada \\
\hline Sim & 23 & 31,9 & 110 & 51,6 & 58 & 71,6 \\
\hline Não & 49 & 68,1 & 103 & 48,4 & 23 & 28,4 \\
\hline Total & 72 & 100,0 & 213 & 100,0 & 81 & 100,0 \\
\hline Disponibilidade a pagar pelo ingresso & 52 & 71,2 & 111 & & & \\
\hline Não & 21 & 28,8 & 105 & 48,6 & 56 & 66,7 \\
\hline Sim & 73 & 100,0 & 216 & 100,0 & 84 & 100,0 \\
\hline Total &
\end{tabular}

Fonte: elaboração própria

Pode-se observar que os níveis de renda pessoal mais baixos estavam relacionados com um grau de escolaridade mais baixo, e que à medida em que o grau de escolaridade ia crescendo para o item que incluía uma pós-graduação, a renda pessoal aumentava. A renda familiar também seguia essa tendência.

Em relação a possibilidade de cobrança de entrada no Parque e a disponibilidade a pagar por essa entrada, observou-se que quanto maior o grau de instrução maior a aceitabilidade em pagar por uma taxa de entrada e a disponibilidade a pagar pela mesma, que pode significar que existe uma intenção de pagamento para a conservação dos bens e serviços do PNCV, à medida que aumenta o grau de escolaridade.

Analisando a variável meio de locomoção (ML) em relação a renda pessoal (RP) e familiar (RF) dos visitantes do PNCV, observou-se os seguintes resultados, de acordo com a Tabela 4 a seguir.

Tabela 4: Comparação da variável meio de locomoção em relação às variáveis RP, RF. 


\begin{tabular}{|c|c|c|c|c|c|c|c|c|}
\hline \multirow{2}{*}{ Meio de locomoção } & \multicolumn{2}{|c|}{ Automóvel } & \multicolumn{2}{|c|}{ Ônibus } & \multicolumn{2}{|c|}{ Avião } & \multicolumn{2}{|c|}{ Outros } \\
\hline & $\mathrm{n}$ & $\%$ & $\mathrm{n}$ & $\%$ & $\mathrm{n}$ & $\%$ & $\mathrm{n}$ & $\%$ \\
\hline \multicolumn{9}{|l|}{ Renda Pessoal (SM) } \\
\hline até $2 \mathrm{SM}$ & 14 & 6,4 & 4 & 20,0 & 8 & 9,0 & 4 & 17,4 \\
\hline 2 a $5 \mathrm{SM}$ & 54 & 24,8 & 10 & 50,0 & 28 & 31,5 & 9 & 39,1 \\
\hline 5 a $10 \mathrm{SM}$ & 63 & 28,9 & 6 & 30,0 & 16 & 18,0 & 4 & 17,4 \\
\hline$>10 \mathrm{SM}$ & 87 & 39,9 & 0 & 0,0 & 37 & 41,6 & 6 & 26,1 \\
\hline Total & 218 & 100,0 & 20 & 100,0 & 89 & 100,0 & 23 & 100,0 \\
\hline \multicolumn{9}{|l|}{ Renda Familiar (SM) } \\
\hline
\end{tabular}

\begin{tabular}{|c|r|r|r|r|r|r|r|r|}
\hline até $4 \mathrm{SM}$ & 11 & 4,9 & 4 & 16,0 & 6 & 6,3 & 3 & 11,5 \\
\hline 4 a $10 \mathrm{SM}$ & 87 & 38,5 & 15 & 60,0 & 37 & 38,5 & 12 & 46,2 \\
\hline$>10 \mathrm{SM}$ & 128 & 56,6 & 6 & 24,0 & 53 & 55,2 & 11 & 42,3 \\
\hline Total & 226 & 100,0 & 25 & 100,0 & 96 & 100,0 & 26 & 100,0 \\
\hline
\end{tabular}

Fonte: elaboração própria

Visualizando-se a tabela acima, constatou-se que na medida em que a renda pessoal e a renda da família dos visitantes foram aumentando, houve um aumento nos percentuais daqueles que fizeram o trajeto da viagem de automóvel ou de avião, combinado com aluguel de automóveis ou ônibus, contribuindo para o aumento do custo de viagem. Aqueles que apresentaram uma faixa intermediária de renda pessoal e/ou familiar viajaram de ônibus, um fator que concerne para a diminuição do custo de viagem.

Ao se comparar a variável renda familiar (RF) com as variáveis acompanhantes de viagem (V) e a disponibilidade a pagar (DAP), constatou-se os seguintes resultados, conforme disposto na Tabela 5.

Tabela 5: Comparação da variável renda familiar em relação às variáveis V, DAP.

\begin{tabular}{|c|c|c|c|c|c|c|}
\hline \multirow{2}{*}{ Renda Familiar (SM) } & \multicolumn{2}{|c|}{ Até $4 \mathrm{SM}$} & \multicolumn{2}{|c|}{4 a $10 \mathrm{SM}$} & \multicolumn{2}{|c|}{$>10 \mathrm{SM}$} \\
\hline & $\mathrm{n}$ & $\%$ & $\mathrm{n}$ & $\%$ & $\mathrm{n}$ & $\%$ \\
\hline \multicolumn{7}{|c|}{ Acompanhantes de viagem (V) } \\
\hline Sozinho & 10 & 41,7 & 22 & 14,6 & 15 & 7,6 \\
\hline Cônjuge/companheiro & 6 & 25,0 & 39 & 25,8 & 72 & 36,4 \\
\hline Família (filhos / pais) & 1 & 4,2 & 34 & 22,5 & 67 & 33,8 \\
\hline Outros & 7 & 29,2 & 56 & 37,1 & 44 & 22,2 \\
\hline Total & 24 & 100,0 & 151 & 100,0 & 198 & 100,0 \\
\hline \multicolumn{7}{|c|}{ Disponibilidade a pagar pelo ingresso (DAP) } \\
\hline Não & 17 & 70,8 & 83 & 55,0 & 91 & 46,0 \\
\hline $\mathrm{Sim}$ & 7 & 29,2 & 68 & 45,0 & 107 & 54,0 \\
\hline Total & 24 & 100,0 & 151 & 100,0 & 198 & 100,0 \\
\hline
\end{tabular}

Fonte: elaboração própria 
Diante do exposto na Tabela 5, observou-se que os visitantes que viajaram sozinhos, cerca de $40 \%$ deles tem renda familiar de até 4 salários mínimos, o que pode ser um limitante do custo de viagem destes. Ao passo que a renda vai aumentando, o percentual de quem viajou acompanhado com cônjuge ou em família foi crescendo, o que contribuiu para aumentar o custo de viagem.

Na comparação da região de origem $(R)$ com as variáveis número de pessoas (NP), tempo de viagem (T) e custo de viagem (CV), o resultado foi o seguinte, conforme a Tabela 6.

Tabela 6: Comparação da região de origem em relação às variáveis NP, T, CV.

\begin{tabular}{|c|c|c|c|c|c|c|}
\hline \multirow[t]{2}{*}{ Região de origem } & \multicolumn{2}{|c|}{ Até $500 \mathrm{~km}(\mathrm{n}=184)$} & \multicolumn{2}{|c|}{$\begin{array}{c}501 \text { até } 1500 \mathrm{~km} \\
(\mathrm{n}=159)\end{array}$} & \multicolumn{2}{|c|}{$>1500 \mathrm{~km}(\mathrm{n}=30)$} \\
\hline & Media & DP & Media & DP & Media & DP \\
\hline Número de pessoas & 3,16 & 2,11 & 2,76 & 2,16 & 3,30 & 2,63 \\
\hline Tempo de viagem & 3,92 & 1,93 & 7,32 & 3,72 & 8,40 & 11,58 \\
\hline Custo de Viagem & 1297,32 & 844,35 & 2666,02 & 1929,47 & 4579,00 & 5341,60 \\
\hline
\end{tabular}

Fonte: elaboração própria

Pelo exposto, pode-se perceber que a região de origem não apresentou uma interferência significativa na variável número de pessoas, cuja média se equiparou para as 3 regiões. Entretanto, constatou-se uma influência no tempo de viagem dos visitantes, mostrando que, quanto mais distante a região, maior a média dos dias permanecidos na localidade.

Para a região I, a média de dias permanecidos na localidade é de aproximadamente 4 dias. Uma viagem de final de semana prolongado, em que com dois dias se conhecia o Parque Nacional, em suas duas trilhas mais dois dias para conhecer os atrativos particulares da região.

Para a regiões II e III, a média de dias gastos com a viagem variavam em torno de 7 e 8 dias, respectivamente. Uma viagem de uma semana, típica de férias, sabendo que nesse tempo inclui-se o tempo de deslocamento, que toma um tempo considerável da viagem, interferindo no acréscimo do tempo de permanência na localidade visitada. Essa variação é confirmada por Lemos (2005, p. 187), "é estabelecida uma relação direta entre tempo de deslocamento origem-destino e tempo de permanência. Quanto maior o primeiro, maior tende a ser o segundo".

Relativo ao custo de viagem, observou-se que o mesmo foi crescente em relação ao distanciamento das regiões ao PNCV. Para a região I, o custo médio foi de $\mathrm{R} \$ 1.297,32$ por respondente, mais que dobrando para a região II, cujo custo médio foi de R\$ 2.666,02; e também quase dobrando em relação a segunda região, para a região III, esse custo foi de $R \$ 4.579,00$. 
Pela análise desses dados pode-se deduzir que o tempo de viagem e o custo de viagem aumentaram em função do aumento da distância da região de origem em relação ao PNCV.

Ao se proceder a análise comparativa entre as variáveis número de pessoas (NP), tempo de viagem (T) e custo de viagem (CV) com a idade (I) dos visitantes, chegou-se aos resultados constantes na Tabela 7.

Tabela 7: Comparação da idade em relação às variáveis NP, T, CV.

\begin{tabular}{|l|c|c|c|c|c|c|c|c|c|c|}
\hline \multirow{2}{*}{ Idade } & \multicolumn{2}{|c|}{$\begin{array}{c}16 \text { e } 25 \text { anos } \\
(\mathrm{n}=61)\end{array}$} & \multicolumn{2}{c|}{$\begin{array}{c}26 \text { e } 35 \text { anos } \\
(\mathrm{n}=148)\end{array}$} & \multicolumn{2}{c|}{$\begin{array}{c}36 \text { e } 45 \text { anos } \\
(\mathrm{n}=84)\end{array}$} & \multicolumn{2}{c|}{$\begin{array}{c}46 \text { e } 60 \text { anos } \\
(\mathrm{n}=75)\end{array}$} & \multicolumn{2}{c|}{$>61$ anos (n=05) } \\
\cline { 2 - 13 } & Media & DP & Media & DP & Media & DP & Media & DP & Media & DP \\
\hline $\begin{array}{l}\text { Número de } \\
\text { pessoas }\end{array}$ & 3,11 & 2,91 & 2,75 & 1,94 & 2,74 & 1,62 & 3,47 & 2,08 & 6,40 & 4,51 \\
\hline $\begin{array}{l}\text { Tempo de } \\
\text { viagem }\end{array}$ & 6,23 & 3,58 & 5,64 & 5,46 & 6,21 & 4,99 & 4,87 & 2,81 & 6,75 & 4,27 \\
\hline $\begin{array}{l}\text { Custo de } \\
\text { Viagem }\end{array}$ & 1528,72 & 1064,08 & 1974,38 & 2570,81 & 2491,71 & 2614,13 & 2547,36 & 1754,86 & 2831,40 & 1775,79 \\
\hline
\end{tabular}

Fonte: elaboração própria

Ao se observar as médias do número de pessoas, percebeu-se que todas as faixas de idade seguiram com números próximos da média (que foi de 3 pessoas por grupo), com exceção da faixa daquelas pessoas maiores de 61 anos de idade, que apresentou média superior a 6 pessoas por grupo. Convém ressaltar que os visitantes dessa faixa de idade viajaram com suas famílias, incluindo no grupo os filhos e netos.

Para o custo de viagem, foi possível observar uma variação crescente, à medida em que a idade do visitante foi aumentando, aproximando-se do dobro, a exemplo, quando se confrontou a 1a faixa (1625 anos), cujo custo de viagem foi de $R \$ 1528,77$ com a última faixa (maior de 61 anos), cujo custo de viagem foi de $R \$ 2831,40$.

Analisando-se a comparação entre as variáveis número de pessoas (NP), tempo de viagem (T) e custo de viagem (CV) com a escolaridade (E), pode-se notar o seguinte, como visto na Tabela 8.

Tabela 8: Comparação da escolaridade em relação às variáveis NP, T, CV.

\begin{tabular}{|l|c|c|c|c|c|c|}
\hline \multirow{2}{*}{ Escolaridade } & \multicolumn{2}{|c|}{ Ensino Médio $(\mathrm{n}=73)$} & \multicolumn{2}{c|}{ Graduação $(\mathrm{n}=216)$} & \multicolumn{2}{c|}{ Outros $(\mathrm{n}=84)$} \\
\cline { 2 - 7 } & Media & DP & Media & DP & Media & DP \\
\hline Número de pessoas & 2,85 & 2,18 & 2,94 & 2,11 & 3,29 & 2,36 \\
\hline Tempo de viagem & 5,93 & 3,91 & 5,80 & 4,99 & 5,33 & 4,27 \\
\hline Custo de Viagem & 1804,38 & 1837,99 & 2192,31 & 2371,11 & 2318,01 & 2291,35 \\
\hline
\end{tabular}

Fonte: elaboração própria 
Ao se observar a variável custo de viagem foi possível perceber que de um nível de escolaridade para outro, houve um acréscimo desse custo, pois um visitante com ensino médio apresentou um custo de viagem em torno de $\mathrm{R} \$ 1804,38$, enquanto um visitante com graduação teve um custo aproximado de $\mathrm{R} \$ 2192,31$ e, por sua vez, um visitante da categoria que possuía uma pós-graduação, esse custo foi de $\mathrm{R} \$ 2318,01$ em média. Essa variação mostrou que, à medida em que o nível de escolaridade evoluiu, o custo de viagem aumentou.

Quando se comparou as variáveis número de pessoas (NP), tempo de viagem (T) e custo de viagem (CV) com a variável meio de locomoção (ML), constatou-se os resultados a seguir, na Tabela 9.

Tabela 9: Comparação do meio de locomoção em relação às variáveis NP, T, CV.

\begin{tabular}{|l|c|c|c|c|c|c|c|c|}
\hline \multirow{2}{*}{\begin{tabular}{c}
\multirow{2}{*}{$\begin{array}{c}\text { Meio de } \\
\text { locomoção }\end{array}$} \\
\cline { 2 - 10 }
\end{tabular}} & \multicolumn{2}{|c|}{$\begin{array}{c}\text { Automóvel } \\
\text { (n=226) }\end{array}$} & \multicolumn{2}{c|}{ Ônibus (n=25) } & \multicolumn{2}{c|}{ Avião (n=96) } & \multicolumn{2}{c|}{ Outros (n=26) } \\
\cline { 2 - 9 } & Media & DP & Media & DP & Media & DP & Media & DP \\
\hline $\begin{array}{l}\text { Número de } \\
\text { pessoas }\end{array}$ & 3,31 & 2,05 & 2,68 & 4,06 & 2,47 & 1,40 & 2,58 & 2,70 \\
\hline $\begin{array}{l}\text { Tempo de } \\
\text { viagem }\end{array}$ & 4,51 & 2,66 & 7,48 & 4,59 & 7,32 & 4,61 & 8,65 & 10,87 \\
\hline Custo de Viagem & 1695,97 & 1247,40 & 1411,04 & 1215,74 & 3070,98 & 2511,94 & 3330,54 & 5427,08 \\
\hline
\end{tabular}

Fonte: elaboração própria

Analisando o resultado da comparação entre o número de pessoas e o meio de locomoção, pode-se perceber que a média do número de viajantes nos variados modais de transportes não diferiu da média dessa variável, indicando um pequeno aumento para os grupos que viajaram de automóvel.

Quanto ao tempo de viagem, observou-se que os visitantes que viajaram de automóvel tenderam a gastar menos dias na viagem, enquanto aqueles visitantes que fizeram uso de outros meios de locomoção tenderam a aumentar seu tempo de viagem. O menor tempo gasto na viagem está vinculado também a uma menor distância da região de origem com a localidade, o que facilita o uso do automóvel como meio de locomoção. Ao passo que essa distância vai aumentando, o tempo de viagem também aumenta e exige um deslocamento mais rápido como a utilização do avião. Nesse aspecto, Lemos (2005, p. 187) assegura que “a lógica é que haja uma relação entre menores distâncias e transporte rodoviário, e maiores distâncias a transporte aéreo".

No que se refere ao custo de viagem em relação aos meios de locomoção, os visitantes que o fizeram por ônibus apresentaram a menor média de custo de viagem, na ordem de $R \$ 1411,08$, seguido pelo 
visitantes que fez o deslocamento por meio de automóvel, com valor próximo de $\mathrm{R} \$ 1695,97$; indicando que o visitante que fez o transporte rodoviário apresentou um menor custo de viagem.

O visitante que fez o deslocamento por meio de avião combinado com aluguel de automóvel, ou com ônibus, apresentou um custo de viagem em torno de $\mathrm{R} \$ 3070,98$. Enquanto que aquele visitante que o fez utilizando além do avião, mais de uma combinação de meios de transporte (automóvel alugado, ônibus ou táxi, em diversos percursos da viagem) teve um custo médio próximo de $\mathrm{R} \$ 3330,54$.

Por esses resultados pode-se observar que o custo de viagem tendeu a ser maior para aqueles visitantes que fizeram parte de sua viagem utilizando o transporte aéreo como meio de locomoção.

Ao se comparar as variáveis número de pessoas (NP), tempo de viagem (T) e custo de viagem (CV) com a renda familiar (RF) dos visitantes, observou-se os seguintes resultados, conforme se pode visualizar na Tabela 10 abaixo.

Tabela 10: Comparação da renda familiar em relação às variáveis NP, T, CV.

\begin{tabular}{|l|c|c|c|c|c|c|}
\hline \multirow{2}{*}{ Renda Familiar (SM) } & \multicolumn{2}{|c|}{ até 4 SM (n=24) } & \multicolumn{2}{c|}{4 a 10 SM (n=151) } & \multicolumn{2}{c|}{$>10 \mathrm{SM}(\mathrm{n}=198)$} \\
\cline { 2 - 7 } & Media & DP & Media & DP & Media & DP \\
\hline Número de pessoas & 2,96 & 3,36 & 2,89 & 2,05 & 3,09 & 2,11 \\
\hline Tempo de viagem & 7,13 & 4,38 & 6,15 & 5,64 & 5,22 & 3,65 \\
\hline Custo de Viagem & 1690,92 & 1921,94 & 2108,05 & 2626,41 & 2227,66 & 1980,95 \\
\hline
\end{tabular}

Fonte: elaboração própria

Foi possível notar uma variação do custo de viagem em função do nível da faixa salarial. Os visitantes com renda familiar na faixa de até 4 salários mínimos apresentou um custo de viagem de $\mathrm{R} \$ 1690,92$; enquanto que aqueles que se situaram numa faixa entre 4 e 10 salários mínimos tiveram um custo de viagem próximo de $\mathrm{R} \$ 2108,05$ e, aqueles cuja renda familiar ultrapassou os 10 salários mínimos, o custo de viagem ficou em $\mathrm{R} \$ 2227,66$. Essa variação mostra uma proporcionalidade entre o custo de viagem e a renda familiar do visitante.

Em relação a disponibilidade a pagar por um ingresso no PNCV, além da taxa do condutor, em comparação com as variáveis número de pessoas (NP), tempo de viagem (T) e custo de viagem (CV), apurou-se os resultados a seguir, como mostrado na Tabela 11. 
Tabela 11 - Comparação da disponibilidade a pagar pelo ingresso em relação às variáveis NP, T, CV.

\begin{tabular}{|l|c|c|c|c|}
\hline \multirow{2}{*}{$\begin{array}{l}\text { Disponibilidade a } \\
\text { pagar pelo ingresso }\end{array}$} & \multicolumn{2}{|c|}{ Não $(\mathrm{n}=191)$} & \multicolumn{2}{c|}{$\operatorname{Sim}(\mathrm{n}=182)$} \\
\cline { 2 - 5 } & Media & DP & Media & DP \\
\hline Número de pessoas & 3,04 & 2,13 & 2,96 & 2,24 \\
\hline Tempo de viagem & 5,83 & 3,44 & 5,61 & 5,63 \\
\hline Custo de Viagem & 2057,03 & 2022,09 & 2236,70 & 2486,81 \\
\hline
\end{tabular}

Fonte: elaboração própria

Ao se observar o exposto na Tabela 11, constatou-se que os visitantes que admitiram uma disponibilidade a pagar pelo ingresso no Parque apresentaram um custo de viagem maior que aqueles que não concordaram com tal pagamento. Esse fato redundaria em custo a mais para o visitante, 0 que pode indicar que o mesmo não se importaria em ter um custo adicional.

Para avaliar as variáveis quantitativas número de pessoas (NP) e tempo de viagem (T) em relação ao custo de viagem (CV), que inclui despesas com transporte, alimentação, hospedagem, atrativos, produtos locais e outros, foi realizada uma análise de regressão linear simples, conforme a Tabela 12 abaixo.

Tabela 12: Análise de regressão linear entre as variáveis NP, T e CV.

\begin{tabular}{|l|c|c|c|}
\hline Fator & Media & DP & b \\
\hline Número de pessoas & 3,00 & 2,18 & 286,29 \\
\hline Tempo de viagem & 5,72 & 4,63 & 309,57 \\
\hline Custo de Viagem & 2144,70 & 2259,53 & \\
\hline
\end{tabular}

Fonte: elaboração própria

A partir da regressão, pode-se denotar que, a cada pessoa a mais em um grupo de viajantes, o custo de viagem aumenta em $\mathrm{R} \$ 286,29$. Na Figura 35, visualiza-se a distribuição do número de pessoas por grupo de viagem apontado pelos entrevistados. 


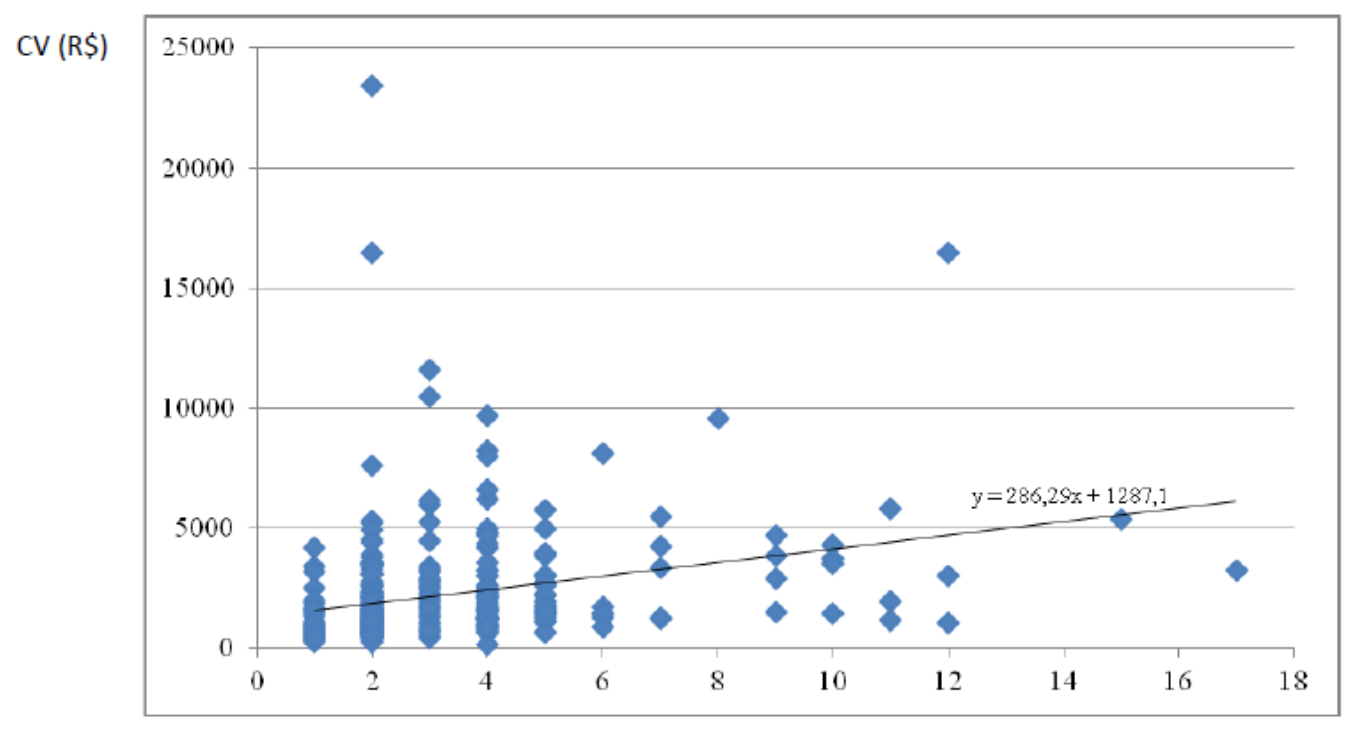

NP

Figura 35: Gráfico da distribuição do número de pessoas (NP) em relação ao custo de viagem Fonte: elaboração própria

Na Figura 36 a seguir, é possível observar a distribuição do tempo de viagem por grupo indicado pelos entrevistados. Constatou-se que cada dia a mais na duração da viagem representa um aumento de $R \$$ 309,57 no custo de viagem.

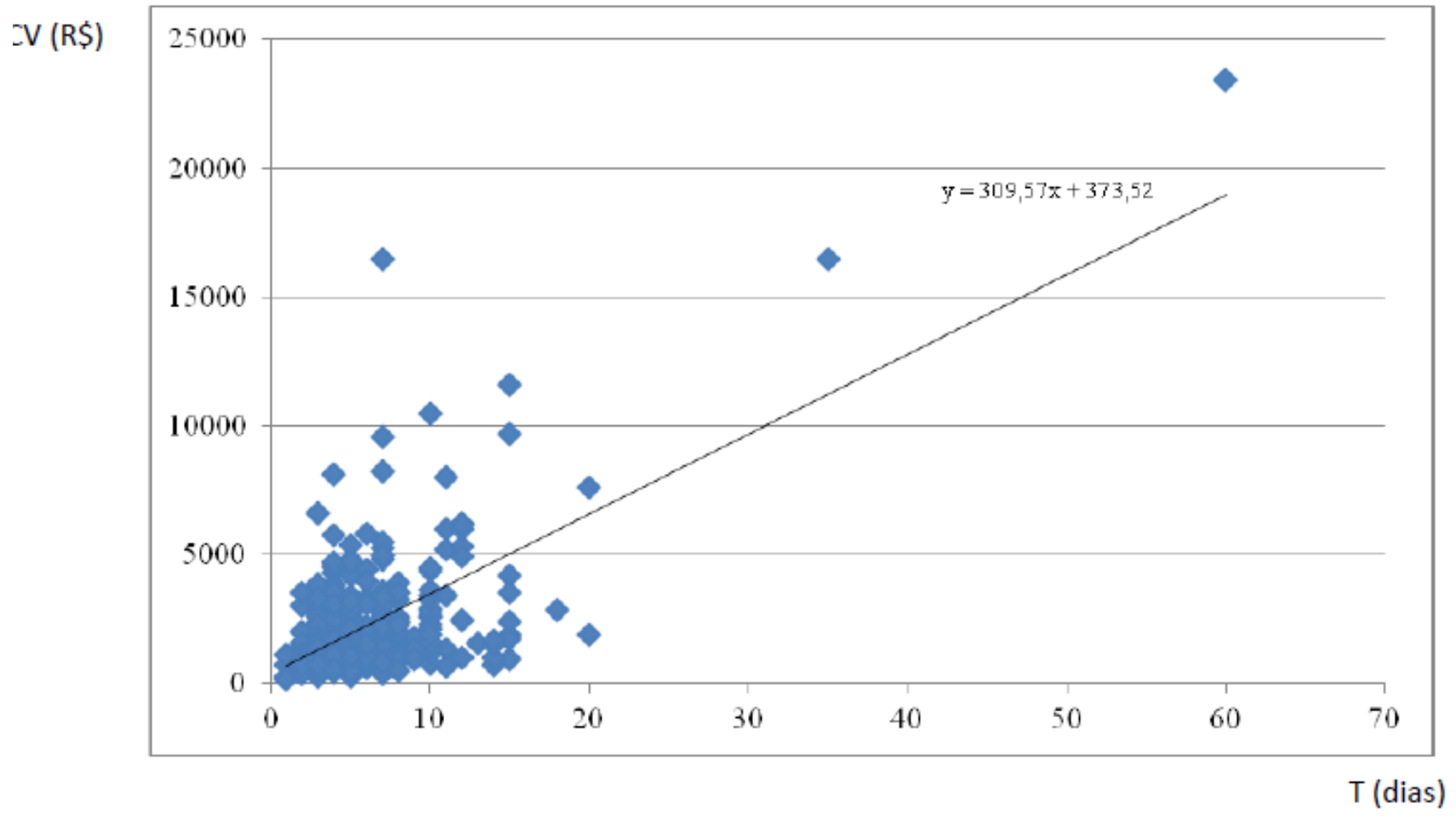

Figura 36: Gráfico da distribuição do tempo de viagem em relação ao custo de viagem.

Fonte: elaboração própria 
Ao se analisar as curvas de tendência nas Figuras 35 e 36, observa-se que as mesmas possuem uma inclinação positiva, o que denota uma proporcionalidade direta entre o número de pessoas e o tempo de viagem com relação ao custo de viagem, indicando que, ao se aumentar o valor de qualquer uma das duas primeiras, haverá um acréscimo no custo de viagem.

Ao se analisar as variáveis NP, T e CV, conforme disposto na Quadro 6 abaixo, observou-se que o número mínimo de pessoas viajando por grupo foi de 1 pessoa, permanecendo por 1 dia na localidade e que o menor custo de viagem correspondeu a $\mathrm{R} \$ 170,00$; ao passo que o número máximo de pessoas viajando em um grupo foi de 17 pessoas, o maior número de dias de viagem foi de 60 dias e que o maior custo de viagem atingiu $\mathrm{R} \$ 23.400,00$.

\begin{tabular}{|l|c|c|c|c|c|}
\hline Variável & Min & Max & 1 Quartil & 2 Quartil & 3 Quartil \\
\hline Número de pessoas & 1,0 & 17,0 & 2,0 & 2,0 & 4,0 \\
\hline Tempo de viagem & 1,0 & 60,0 & 3,0 & 5,0 & 7,0 \\
\hline Custo de Viagem & 170,0 & 23400,0 & 920,0 & 1500,0 & 2600,0 \\
\hline
\end{tabular}

Quadro 6 - Distribuição da amostra por quartis Fonte: elaboração própria

Referente ao primeiro quartil da amostra, pode-se notar que o número de pessoas foi de 2 por grupo, com um tempo de viagem de 3 dias e um custo de viagem de até $R \$ 920,00$. Para o segundo quartil o número de pessoas por grupo permaneceu o mesmo, aumentando-se o tempo de viagem para 5 dias e o custo de viagem para até $\mathrm{R} \$ 1.500,00$. No terceiro quartil, o número de pessoas passou para 4 por grupo, com um tempo de viagem de até 7 dias e o custo de viagem atingiu o valor de $R \$ 2.600,00$.

Quanto ao custo total da viagem, por parte dos visitantes do PNCV, este foi calculado somando-se as despesas com transporte, alimentação, pagamento de entradas em atrativos, hospedagem, produtos locais (como artesanato, lembranças, etc.) e outros (medicamentos, gastos imprevistos), foi apurada

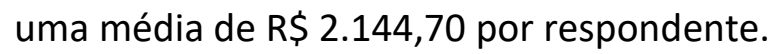

Desmembrando-se os dados e fazendo os cálculos de acordo com as Regiões I, II e III (modelo zonal), os custos de viagem (CV), número de viajantes (NP) e o número de dias de duração da viagem (T) com suas respectivas médias, os resultados apresentaram-se da seguinte forma como a Tabela 14, na sequência. 
Tabela 14: Dados comparativos do CV, T e NP dos visitantes do PNCV das Regiões I, II e III - julho/2012

\begin{tabular}{|c|c|c|c|c|}
\hline Região & $\mathrm{CV}(\mathrm{R} \$)$ & $\mathrm{NP}$ (pessoas) & $\mathrm{T}$ (dias) & $\mathrm{R} \$ /$ pes./dia \\
\hline I & $1.297,32$ & 3,16 & 3,92 & 104,73 \\
\hline II & $2.666,02$ & 2,76 & 7,32 & 131,96 \\
\hline III & $4.579,00$ & 3,30 & 8,40 & 165,19 \\
\hline Geral* & $2.144,70$ & 3,00 & 5,72 & 124,98 \\
\hline
\end{tabular}

* O item Geral refere-se à média agregada dos ítens das regiões I, II e III.

Assim, foi possível determinar, conforme se pode visualizar na Tabela 14 acima, que o custo de viagem agregado para as 3 regiões ficou em torno de $R \$ 124,98$ por pessoa/dia, sendo que esse item referente à região I, R\$104,73 por pessoa/dia, não atingiu a média geral, enquanto que os custos das regiões II e III, $R \$ 131,96$ por pessoa/dia e $R \$ 165,19$ por pessoa/dia, respectivamente, excederam a média agregada de custo de viagem das 3 regiões.

\section{CONSIDERAÇÕES FINAIS}

Embora a criação das áreas protegidas brasileiras tenha sido implantada seguindo o modelo da natureza intocada, percebe-se que as mesmas apresentam uma ligação muito forte com as comunidades que lhes rodeiam, ou que até mesmo residem em seu interior.

No caso dos Parques Nacionais, ainda que sejam unidades de proteção integral, as pessoas residentes no seu entorno de certa forma dependem dos bens e serviços que estes possuem para sobreviver, seja na forma de uso direto ou indireto, e até mesmo de não uso, o que lhes confere uma importância por sua existência.

A preocupação em conservar esses bens e serviços para usufruto das gerações atuais, como das vindouras, revela que se lhes atribuem uma determinada valorização. Ainda que não se tenha definido um mercado específico para esses bens e serviços, já se vislumbra um valor para os mesmos. Ao se buscar a natureza do valor e entender o valor da natureza, é possível trabalhar pela sustentabilidade, em garantia da conservação dos ecossistemas que essas unidades encerram.

Também é necessário frisar que esses processos de conservação devem levar em consideração a presença das pessoas nos diversos meios e que deve haver uma integração que congregue os processos sociais e os ecológicos, numa "conciliação" em que nos modos de vida das populações se 
incluam a manutenção da biodiversidade, a exemplo do que afirmou Bensusan (2006). As relações homem-natureza devem ser vistas como um meio para transformar as comunidades locais, mantendo a sua reprodução econômica e social.

Nesse aspecto, o PNCV, mesmo seguindo os expedientes normais para a implantação de uma Unidade de Conservação na Chapada dos Veadeiros, representou e tem representado um agente de transformação da realidade das pessoas da localidade do Distrito de São Jorge e das suas imediações.

Em um século de menções da atividade humana na região, a primeira metade foi restrita às atividades da garimpagem associada à agricultura de subsistência, atividades estas que de certa forma contribuíram para deixar suas marcas no ambiente local.

A garimpagem por sua vez era uma atividade depredatória do ambiente, em que o garimpeiro se preocupava simplesmente em "fazer riqueza", explorando cada vez mais os recursos daquele local, para atender a uma demanda que também se pautava por uma visão economicista. Esse fato pode ser ilustrado pelo que expôs um ex-garimpeiro, "a destruição vai arrancando é tudo, (se não chegasse o pessoal do MA) tinha arrasado com tudo" e pode ser visto nas catas do Morro do Garimpão, vestígios que marcaram uma época de extrema exploração.

Assim que se instalou a UC, em 1961, nos trinta anos subsequentes as relações são marcadas por confrontos e conflitos, envolvendo a questão da posse da terra para os fazendeiros e posseiros, e para os garimpeiros a proibição de exercer a atividade do garimpo, "não podia trabalhar mesmo, de qualquer maneira".

Na década de 1990, com o advento e com o ganho de força da atividade turística, as pessoas voltaram seu olhar para a nova atividade, que não deixou de lhes garantir renda, mas exigiu uma nova postura frente ao meio ambiente. Nesse momento houve um enaltecimento da conservação ambiental, especialmente dos ex-garimpeiros, que se trasformaram em condutores de visitantes, nas trilhas do PNCV, como também nas trilhas das propriedades dos arredores de São Jorge.

Aconteceu então uma reconfiguração do modo de vida das pessoas da localidade, e não só os garimpeiros mudaram a sua conduta frente aos domínios do Parque Nacional. Outras pessoas também começaram a usufruir dos benefícios propiciados por um dos objetivos da UC, o de ser locus da prática do ecoturismo. Donas de casa abriram restaurantes, outros moradores montaram pousadas, áreas de camping, estabelecimentos comerciais para receber os turistas, pessoas de outras localidades também ali se estabeleceram buscando oportunidades decorrentes da atividade turística. 
Toda essa transformação alterou as referências de valores das pessoas da localidade, como frisou um morador, o turismo mudou a visão das pessoas, o "sujeito que valorizou mais as coisas, tinha uma visão de construir as coisas prá ele", contrapondo-se à época da garimpagem, quando conforme afirmou outro morador "todo mundo vivia isolado no meio do mato".

Foi necessária uma organização das pessoas da comunidade para até mesmo entender o processo da atividade que se iniciava. Criaram-se as associações (ASJOR, ACVCV, dentre outras) e por meio delas conseguiram resolver problemas de acesso a serviços básicos como abastecimento de água, energia elétrica, serviços de saúde e educação, melhorando as condições de vida dos moradores da vila.

A criação do Parque Nacional, e com ele o desenvolvimento da atividade turística, induziu as pessoas a trabalharem coletivamente, o que garantiu, de certa forma, o seu empoderamento frente a uma nova realidade. Esse fortalecimento se deu pela via da questão ambiental, que levou a uma mudança de mentalidade em relação ao Parque, fazendo surgir novos valores ligados ao meio ambiente.

Os donos de propriedades rurais das imediações do Distrito, na Zona de Amortecimento do Parque Nacional, que antes praticavam uma agricultura voltada para a subsistência, cumprindo uma função produtiva, em virtude das restrições da criação da UC, abriram suas porteiras para os turistas, aproveitando os atrativos aí presentes. Da função produtiva deslocaram-se para a função de conservação ambiental em seus domínios, enquadrando-se no âmbito da multifuncionalidade dos espaços rurais.

Houve uma mudança no foco das atividades do fazer dos moradores da localidade, em que a conservação do meio ambiente passou a ter um valor maior e foi se tornando uma fonte de renda, garantindo o "sustento" das pessoas. Esse processo, alavancado pelo funcionamento do Parque Nacional, tornou-se o carro chefe do turismo desenvolvido na Chapada dos Veadeiros.

Além do caráter econômico, o Parque também passou a ter o seu valor no aspecto cultural e de identificação das pessoas com o local. Muitos dos ex-garimpeiros e condutores de visitantes associam todo o seu conhecimento e sua experiência de vida com os caminhos do Parque, que se confundem com as suas histórias, como se referiu a Agente Administrativa da UC, a uma questão de pertencimento, ao mencionar quando um condutor de visitantes relatou, "isso aqui faz parte da minha vida, não é só o meu ganha-pão" (nas discussões sobre a efetivação da aplicação da IN 08 do ICMBio, que liberou a obrigatoriedade do acompanhamento do condutor de visitantes nas trilhas do PNCV). 
Esse fato revelou a noção dos valores que o Parque representa para as pessoas da localidade e pode indicar como os mesmos estão presentes no cotidiano do lugar. Essa nova situação mostra bem como a valorização do Parque está colocada para os moradores, e que também pode interferir em suas concepções de valores, que surgiram com a instalação da UC.

Percebe-se que o Parque Nacional representa uma gama de valores para as pessoas residentes no Distrito de São Jorge e suas imediações. Primeiramente um valor na esfera econômica, pois é o principal elemento indutor para a formação de renda, possibilitando a reprodução socioeconômica dos moradores da região, por intermédio da atividade turística.

Também se reveste de um valor ambiental, pois por suas características ímpares, permitem a conservação da biodiversidade do cerrado que é restrita à região. Muitos dos moradores, e principalmente os ex-garimpeiros, têm um conhecimento sobre as plantas e suas propriedades, e hoje destacam a importância do Parque para sua preservação.

Outra referência de valor reside no aspecto sociocultural, pois a história transcorrida na região, com a garimpagem do cristal e depois com a instalação da UC, permitiu mostrar as várias nuances da relação homem-natureza, em que houve o contraste de uma atividade altamente depredatória do ambiente, com atitudes voltadas para a conservação ambiental. Esse aspecto desvendou à sociedade em geral, que é possível montar "arranjos" e modelos mais sustentáveis em relação à exploração do conjunto de bens e serviços de uma localidade.

Em suma, pode-se afirmar que o PNCV constitui-se em um elemento de desenvolvimento socioeconômico e ambiental para a região do Território da Chapada dos Veadeiros, em benefício de sua população.

No caso, com o emprego do MCV, buscou-se uma referência ao valor monetário de uso direto dos bens e serviços do PNCV. Valores esses baseados nas preferências dos consumidores e que mostram uma disposição a pagar pelo usufruto desses bens e serviços ambientais, constituindo-se em um indicador automático dessas preferências. Se as pessoas pagam um determinado valor monetário, para a realização dessa viagem, supõe-se ser o quanto estipulam que valham tais bens e serviços.

Como esses bens e serviços não possuem um mercado com preços estabelecidos, subentende-se que, baseado na teoria da demanda do consumidor, no modelo de mercado de bens complementares, os visitantes atribuíram valores monetários aos mesmos equivalentes às despesas que tiveram com a viagem. Essas despesas incorreram nos gastos diretos e indiretos com o passeio e revelaram uma 
disposição a pagar para usufruir dos bens e serviços que o Parque e os atrativos dos arredores do Distrito oferecem.

No geral, a média do custo de viagem por visitante foi de $\mathrm{R} \$ 124,98$ por pessoa, ao dia, no período pesquisado, conforme os dados da pesquisa. Esse é o valor monetário revelado pelos visitantes entrevistados, com base em suas despesas, para realizar a viagem e que os mesmos estavam dispostos a pagar para usufruir dos bens e serviços que o PNCV e os atrativos dos arredores do Distrito de ao Jorge propiciaram. Um valor econômico de uso direto, dos bens e serviços que esses atrativos podem proporcionar. É conveniente ressaltar, que no mês de julho de 2012, quando a pesquisa foi realizada, passaram pelo Parque Nacional 4.714 visitantes, e ao final do ano somaram-se 23.014 visitantes, conforme a administração da UC. São os valores revelados por meio do MCV, de forma monetária, pois essa é a forma de apreensão de valores para a teoria econômica.

Além dos valores monetários revelados pelos visitantes, que reflete a esfera econômica de uma viagem a um sítio com suas belezas naturais, foi possível captar junto a essas pessoas outros valores associados a um passeio como esse. Os valores de não uso presentes no PNCV e nos atrativos dos arredores não foram quantificados e determinados monetariamente porque o MCV não é uma metodologia apropriada para tal, contudo a pesquisa captou que eles existem entre os entrevistados.

Os elementos culturais e relações sociais também se somam aos motivos da viagem, e o visitante busca outros valores, como a interação com outras comunidades e o próprio contato com o meio ambiente, são os valores extra-monetários.

Ao se questionar os visitantes sobre o porquê da viagem e a motivação da viagem, foi possível perceber que outros valores permeiam um passeio como esse, e que foram captados, seguindo a Escala Motivacional do Lazer, proposta por Ragueb e Beard, descrita por Swarbrooke e Horner (2002). Desses valores não monetários destacados, aqueles que se relacionavam com o conhecimento foram os que mais os visitantes mencionaram. O conhecimento do bioma cerrado, principalmente por parte daqueles visitantes que se deslocaram de outras regiões do país, a exemplo do que relatou um entrevistado ao apontar o passeio como "uma experiência integrativa, passando por vários ambientes (biomas) e acompanhando a expansão das fronteiras".

Nesse quesito do conhecimento, os visitantes destacaram também a questão do auto-conhecimento, que uma viagem como essa proporciona às pessoas, o "conhecimento de si mesmo diante da natureza", por intermédio da interação e do equilíbrio com o meio ambiente. 
Observou-se nas respostas dos visitantes, principalmente aqueles que viajaram com suas famílias, uma preocupação de se transmitir aos filhos com a viagem valores ligados ao "respeito de uma forma mais ampla, não só aos seus limites, como também aos da natureza", cujo respondente qualificou como o valor relacionado à questão ambiental.

Outro componente citado pelos visitantes foi a possibilidade de, com a viagem, as pessoas poderem sair um pouco das grandes cidades, a fuga da dinâmica urbana, buscando a tranquilidade de um local no interior, em contato com as paisagens que um Parque Nacional pode oferecer.

O convívio entre as pessoas, não só nos grupos de viajantes, mas também o contato com outras culturas foi ressaltado por parte dos visitantes, ao que atribuíram como sendo elementos que revestem de valores sociais, que uma viagem como essa propicia.

Como se pode observar nas localidades de origem dos visitantes, grande parte dos entrevistados provieram de grandes centros urbanos do país, principalmente de Brasília e São Paulo. Tais pessoas traziam consigo uma visão de valorização dos bens e serviços que um sítio natural possui. A chegada desses visitantes ao Distrito de São Jorge constituiu em um elemento para também transformar a visão acerca do ambiente dos moradores da localidade, que por sua vez, passaram a valorizar aquele local, não só como o meio de garantir a sua subsistência, mas para atuarem na defesa e na preservação ambiental.

Assim, na visão dos visitantes, há um conjunto de bens e serviços no PNCV e nos arredores do Distrito de São Jorge que encerram valores monetários e não monetários. Os monetários foram aqueles revelados pelos seus gastos com a viagem - o custo de viagem - que expressam uma disposição a pagar pelo usufruto dos bens e serviços da localidade. Os não monetários foram percebidos e destacados pelas pessoas em geral, mas que pela metodologia adotada nesse estudo não foram mensurados, todavia não deixam de existir.

Assim o PNCV, o Distrito de São Jorge e suas imediações apresentam em si diversos valores em função dos bens e serviços ambientais que possuem e oferecem. Esses valores foram se transmutando ao longo do tempo e das atividades socioeconômicas que aí se desenvolveram, a partir do ponto de vista das várias pessoas que encontravam uma significação para o local, os garimpeiros, os agricultores, os extrativistas, os moradores em geral, os representantes das instituições, os condutores de visitantes, os donos de estabelecimentos, os turistas e outros mais. 
E essa noção de valor vai se balizar nas relações que a sociedade tiver com a natureza, em um dado momento. Por isso, essa temática socioambiental suscitará novos estudos e análises para rever e avaliar esses novos valores surgidos. 


\section{REFERÊNCIAS}

ABRAMOVAY, Ricardo. O capital social dos territórios: repensando o desenvolvimento rural. Revista Economia Aplicada, Ribeirão Preto, v. 4, n. 2, abr./jun. 2000.

- Para uma teoria dos estudos territoriais. In: ORTEGA, Antonio C. \& ALMEIDA FILHO, Niemeyer. (orgs.). Desenvolvimento Territorial, Segurança Alimentar e Economia Solidária. Campinas: Editora Alínea, 2007.

.Agricultura familiar e desenvolvimento territorial. Reforma Agrária: Revista da Associação Brasileira de Reforma Agrária. Campinas, v. 28/29, 1999. Disponível em: <http://www.econ.fea.usp.br/abramovay/artigos_cientificos.htm> Acesso em: 15 dez. 2012.

ADAMS, Cristina et al. Valoração econômica do Parque Estadual Morro do Diabo (SP). São Paulo: Páginas \& Letras Editora e Gráfica, 2003.

ALBERTI, Verena. História oral: a experiência do CPDOC. Rio de Janeiro: Centro de Pesquisa e Documentação de História Contemporânea do Brasil, 1989.

ALBUQUERQUE, José A. M. A construção do espaço na Chapada dos Veadeiros. In: DUARTE, Laura M. G.; BRAGA, Maria L. S. (Orgs.) Tristes cerrados. Sociedade e biodiversidade. Brasília: Ed. Paralelo 15, 1998, p.223-257.

ANDRADE, Daniel A. e ROMEIRO, Ademar R. Serviços ecossistêmicos e sua importância para o sistema econômico e o bem-estar humano. Texto para discussão. IE/Unicamp, Campinas, n.155, fev. 2009.

AMAZONAS, Maurício C. Valor ambiental em uma perspectiva heterodoxa institucional-ecológica. Revista economia e sociedade, Campinas, v. 18, n. 1 (35), p.183-212, abr. 2009.

. Desenvolvimento sustentável e teoria econômica: o debate conceitual nas perspectivas neoclássica, institucionalista e da economia ecológica. In: NOBRE, Marcos; AMAZONAS, Maurício C. Desenvolvimento sustentável: a institucionalização de um conceito. Brasília: Ed. IBAMA, 2002. p. 107-286.

BARBOSA, Álan G. As estratégias de conservação da biodiversidade na Chapada dos Veadeiros: conflitos e oportunidades. 2008. Dissertação (Mestrado em Desenvolvimento Sustentável), Universidade de Brasília. Brasília, 2008. Disponível em:

<http://repositorio.unb.br/bitstream/10482/1040/1/2008_AlanGoncalvesBarbosa.pdf> Acesso em: 03 jul. 2012.

BEHR, Miguel von. Berço das águas e do novo milênio: Chapada dos Veadeiros, Goiás, Brasil. Brasília: Editora UnB: Editora IBAMA, 2000.

BENI, Mário C. Análise estrutural do turismo. 7 ed. São Paulo: Editora SENAC São Paulo, 2002.

BENSUSAN, Nurit. Conservação da biodiversidade em áreas protegidas. Rio da Janeiro: Editora FGV, 2006. 
BERTRAN, Paulo. História de Niquelândia: do Julgado de Traíras ao Lago de Serra da Mesa. Brasília: Verano Editora, 2002.

BEZERRA DA SILVA, Cleide. Chapada dos Veadeiros: uma utopia em construção ou um novo discurso para velhas práticas? In: DUARTE, Laura M. G.; BRAGA, Maria L. S. (Orgs.) Tristes cerrados. Sociedade e biodiversidade. Brasília: Ed. Paralelo 15, 1998, p.191-221.

BRAGA, Maria L. S. e PIRES, Mauro O. Parques ecológicos e população no Distrito Federal: à procura da "natureza" e do lazer. In: DUARTE, Laura M. G. e THEODORO, Suzi H. (Orgs.). Dilemas do cerrado: entre o ecologicamente (in)correto e o socialmente (in)justo. Rio de Janeiro: Garamond, 2002, p. 2756.

BRANDÃO, Carlos. Território e Desenvolvimento: as múltiplas escalas entre o local e o global. Campinas: Editora da UNICAMP, 2007.

. Territórios com classes sociais, conflitos, decisão e poder. In: ORTEGA, Antonio C. e ALMEIDA FILHO, Niemeyer (Orgs.). Desenvolvimento territorial, segurança alimentar e economia solidária. Campinas: Editora Alínea, 2009, p. 39-61.

BRANDÃO, Paulo A.C.A.; BARRETO, Renata V. Impactos Ambientais do Ecoturismo na Vila de São Jorge, entrada do Parque Nacional do Parque dos Veadeiros. In: STEINBERGER, Marília. Territórios Turísticos no Brasil Central. Brasília: LGE Editora, 2009, p. 353-378.

BRASIL. Lei federal no 9.985, de 18 de julho de 2000. Regulamenta o art.225, § 1o, incisos I, II, III e VII da Constituição Federal, institui o Sistema Nacional de Unidades de Conservação da Natureza e dá outras providências. Brasília, 2000. Disponível em:

<http://www.planalto.gov.br/ccivil_03/leis/I9985.htm> Acesso em: 14 jan. 2013.

BRASIL, Ministério do Meio Ambiente, Instituto Chico Mendes de Conservação da Biodiversidade. Instrução Normativa № 08, de 18 de setembro de 2008. Brasília, 2008.

BRASIL. Ministério do Meio Ambiente. Instituto Chico Mendes de Conservação da Biodiversidade. Plano de Manejo do Parque Nacional da Chapada dos Veadeiros. Brasília, 2009. Disponível em: <www.icmbio.gov.br/parna_veadeiros> Acesso em 19 out. 2010.

BRASIL, Ministério do Meio Ambiente. Conselho Nacional do Meio Ambiente. Resolução № 428, de 17 de dezembro de 2010. Brasília, 2010.

BRASIL, Ministério do Desenvolvimento Agrário. Territórios da cidadania. Brasília: 2013.

CAMPHORA, Ana L. e MAY, Peter H. A valoração ambiental como ferramenta de gestão em unidade de conservação: há convergência de valores para o bioma Mata Atlântica? Revista Megadiversidade: Desafios econômicos para a conservação ambiental, Belo Horizonte, vol. 2, n.1-2, p.24-38, 2006.

CARNEIRO, Maria J. Pluriatividade da agricultura no Brasil: uma reflexão crítica. In: SCHNEIDER, Sérgio. (Org.). A diversidade da agricultura familiar. Porto Alegre: Ed. da UFRGS, 2009, p. 167-187.

. Ruralidades contemporâneas: modos de viver e pensar o rural na sociedade brasileira. Rio de Janeiro: Mauad X: FAPERJ, 2012. 
CARNEIRO, Maria. J. \& TEIXEIRA, Vanessa. L. Pluriatividade, novas ruralidadese e identidades sociais. In: CAMPANHOLA, C. \& GRAZIANO DA SILVA, J. O novo rural brasileiro: novas ruralidades e urbanização. Brasília: Embrapa Informação Tecnológica, 2004, p. 15-38.

- De terra de plantação à terra de lazer. In: CARNEIRO, Maria. J. (Org.). Ruralidades contemporâneas: modos de viver e pensar o rural na sociedade brasileira. Rio de Janeiro: Mauad X: FAPERJ, 2012, p. 67-100.

CASIMIRO FILHO, Francisco. Valoração monetária de amenidades ambientais: algumas considerações. In: Revista Teoria e Evidência Econômica, Passo Fundo, v.7, n.13, p.53-68, nov./1999. Disponível em <http://www.upf.br/cepeac/download/rev_n13_1999_art3.pdf> Acesso em: 23 maio 2012.

CASTRO, Edna. Território, biodiversidade e saberes de populações tradicionais. In: DIEGUES, Antonio C. (Org.). Etnoconservação: novos rumos para a conservação da natureza. São Paulo: NUPAUB/USP, 2000, p. 165-182.

CASTRO NETO, João C. P. Determinação do tamanho de uma amostra. Curitiba: FESP/PR, 2004. Disponível

em

<http://www.fesppr.br/ centropesq/Calculo_do_tamanho_da_amostra/Tamanho\%20da\%20Amostr a\%20-\%201.pdf> Acesso em: 09 jul. 2012.

CHALITA, Marie. A. N. Desenvolvimento rural, agricultura e natureza: novas questões de pesquisa. Agricultura São Paulo. São Paulo, v. 52, n. 1, p. 97-113, jan./jun. 2005. Disponível em <http://www.iea.sp.gov.br/out/publicacoes/pdf/asp-1-05-7.pdf> Acesso em: 29 ago. 2012.

CHIZZOTTI, Antonio. Pesquisa em ciências humanas e sociais. 11 ed. São Paulo: Cortez, 2010.

COLCHESTER, Marcus. Resgatando a natureza: comunidades tradicionais e áreas protegidas. In: DIEGUES, Antonio C. (org.). Etnoconservação: novos rumos para a conservação da natureza. São Paulo: NUPAUB/USP, 2000, p. 225-256.

CMMAD (Comissão Mundial sobre Meio Ambiente e Desenvolvimento). Nosso futuro comum. Rio de Janeiro: FGV, 1991.

CORIOLANO, Luzia N. M. T. O ecoturismo e os hóspedes da natureza. In: BARRETO, Margarita e TAMANINI, Elizabete (Orgs). Redescobrindo a ecologia no turismo. Caxias do Sul: EDUCS, 2002, p. 35 70.

DENCKER, Ada F. N. Pesquisa em turismo: planejamento, métodos e técnicas. São Paulo: Futura, 2007.

DENZIN, Norman K. e LINCOLN, Yvonna S. Introdução: a disciplina e a prática da pesquisa qualitativa. In: DENZIN, Norman K. e LINCOLN, Yvonna S. (Orgs.) O planejamento da pesquisa qualitativa: teorias e abordagens. Porto Alegre: Artmed, 2006, p. 15-41.

DIAS, Reinaldo. Turismo sustentável e meio ambiente. São Paulo: Atlas, 2003.

DIEGUES, Antonio C. e NOGARA, Paulo J. O nosso lugar virou parque: estudo sócio-ambiental do Saco de Mamanguá - Parati - Rio de Janeiro. 2. Ed. São Paulo: NUPAUB/USP, 1999. 
DIEGUES, Antonio C. Repensando e recriando as formas de apropriação comum dos espaços e recursos naturais. In; DIEGUES, Antonio C. e MOREIRA, André de C. C. (Orgs.). Espaços e recursos naturais de uso comum. São Paulo: NUPAUB/USP, 2001, p. 97-124.

Hucitec/NUPAUB/USP, 2000.

O mito moderno da natureza intocada. 3. ed. São Paulo:

DOLES, Dalísia E. M. Interpretação histórica da economia de Goiás e posicionamento do setor agropecuário no contexto econômico e social da região. Goiânia: Secretaria de Agricultura e Abastecimento do Estado de Goiás, 1995.

DOMICIANO, Carlos S.; CAUME, David J. Inserção no agronegócio pelo cooperativismo: a experiência da "Cooperaçafrão" em Mara Rosa-GO. Pesquisa Agropecuária Tropical, Goiânia, v. 38, p. 169-179, jul./set. 2008.

DOMICIANO, Carlos S.; OLIVEIRA, Ivanilton J. Cartografia dos impactos ambientais no Parque Nacional da Chapada dos Veadeiros (GO). Mercator, Fortaleza, vol.11, n.25, p.179-199, mai/ago 2012. Disponível em <www.mercator.ufc.br> Acesso em 23 ago. 2012.

DOMICIANO, Carlos S., RIBEIRO, Francis L. e SILVA DOMICIANO, Felipe. Ecoturismo: desenvolvimento pela via do capital social. In: ENCONTRO NACIONAL DE EDUCAÇÃO AMBIENTAL E V ENCONTRO NORDESTINO DE BIOGEOGRAFIA, CNEA. III. 2013, João Pessoa. Anais... João Pessoa: Editora da UFPB, 2013, p. 548-559.

DUARTE, Laura M. G. Globalização, agricultura e meio ambiente: o paradoxo do desenvolvimento dos cerrados. In: DUARTE, Laura M. G. (org.) e BRAGA, Maria L. S. Tristes cerrados. Sociedade e biodiversidade. Brasília: Ed. Paralelo 15, 1998, p. 11-22.

. Desenvolvimento sustentável: um olhar sobre os cerrados brasileiros. In: DUARTE, Laura M. G.; THEODORO, Suzi H. Dilemas do cerrado: entre o ecologicamente (in)correto e o socialmente (in)justo. Rio de Janeiro: Garamond, 2002, p. 11-24.

ESTEVAM, Luiz A. Agricultura tradicional em Goiás. In: PEREIRA, A. A. et al. Agricultura de Goiás: análise e dinâmica. Goiânia: A. A. Pereira, 2004.

EUROPEAN COMMUNITIES. A economia dos ecossistemas e da biodiversidade: um relatório preliminar. Cambridge (Reino Unido): Banson, 2008.

FACHEUX, S.; NOËL, J. F. Economia dos recursos naturais e do meio ambiente. Lisboa: Instituto Piaget, 1995.

FLICK, Uwe. Introdução à pesquisa qualitativa. Tradução: Joice Elias Costa. - 3. ed. - Porto Alegre: Artmed, 2009.

FREITAS, Henrique et al. O método de pesquisa survey. Revista de administração. São Paulo, v. 35, n. 3, p. 105-112, jul./set. 2000. Disponível em:

<http://www.clam.org.br/bibliotecadigital/uploads/publicacoes/1138_1861_freitashenriquerausp.p df> Acesso em: 14 ago. 2012. 
FROEHLICH, José M. Identidades e tradições reinventadas: o rural como tema e cenário. In: CARNEIRO, Maria. J. (Org.). Ruralidades contemporâneas: modos de viver e pensar o rural na sociedade brasileira. Rio de Janeiro: Mauad X: FAPERJ, 2012, 201-226.

GOLDENBERG, Mirian. A arte de pesquisar: como fazer pesquisa qualitativa em ciências sociais. 4 ed. Rio de Janeiro: Record, 2000.

GRAZIANO DA SILVA, José. O novo rural brasileiro. Campinas: Editora UNICAMP, 2002a.

. Velhos e novos mitos do rural brasileiro: implicações para as políticas públicas. In: CASTRO, Ana C. Desenvolvimento em debate. Rio de Janeiro: Ed. Mauad/BNDES, 2002b, p. 411-435. Disponível em:

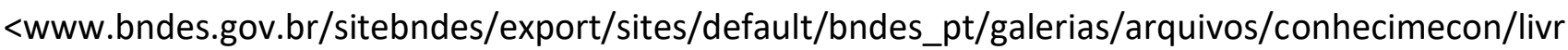
o_debate/3-desenvolvimento rural.pdf> Acesso em: 07 dez. 2010.

GUANAES, Senilde A. "Meu quintal não é Parque!": populações locais e gestão ambiental no Parque Nacional da Chapada Diamantina - BA. 2006. Tese (Doutorado em Ciências Sociais) Universidade Estadual de Campinas, Campinas, 2006.

GUANZIROLLI, Carlos E. Experiências de desenvolvimento territorial rural no Brasil. Texto para discussão $n^{\circ}$ 188. Niterói, 2006. Disponível em:

<http://www.uff.br/econ/download/tds/UFF_TD188.pdf> Acesso em 25 set. 2012.

GÜRLÜK, Serkan e REHBER, Erkan. A travel cost study to estimate recreacional value for a bird refuge at Lake Manyas, Turkey. In: Journal of ennironmental management 88, 2008, p.1350-1360. Disponível em <www.elsevier.com/locate/jenvman> Acesso em: 30 maio 2012.

HAAB, Timothy C.; McCONNELL, Kenneth E. Valuing environmental and natural resources: the econometrics of non-market valuation. Cheltenham: Edward Elgar Publishing Limited: Northamptom: Edward Elgar Publishing, Inc., 2002.

HAGUETTE, Teresa. M. F. Metodologias qualitativas na Sociologia. Petrópolis: Ed. Vozes, 2001.

HAUFF, Shirley N. Relações entre comunidades rurais locais e administração de parques no Brasil: subsídios ao estabelecimento das zonas de amortecimento. 2004. 224 f. Tese (Doutorado em Engenharia Florestal), Universidade Federal do Paraná, Curitiba, 2004. Disponível em: <http://www.floresta.ufpr.br/pos-graduacao/defesas/pdf_dr/2004/t163_0183-D.pdf> Acesso em: 17 out. 2013.

HERCOWITZ, Marcelo; MATTOS, Luciano; SOUZA, Raquel P. Estudos de casos sobre serviços ambientais. In: MATTOS, L. \& HERCOWITZ, M. Economia do meio ambiente e serviços ambientais: estudo aplicado à agricultura familiar, às populações tradicionais e aos povos indígenas. Brasília: Embrapa Informação Tecnológica, 2011, p. 163-294.

HOUAISS, Antônio; VILLAR, Mauro S. Dicionário Houaiss da língua portuguesa. Rio de Janeiro: Objetiva, 2009.

HUGHES, Buz. Plano de ação para a conservação do pato-mergulhão. Brasília: MMA/IBAMA, 2006. 
INSTITUTO BRASILEIRO DE GEOGRAFIA E ESTATÍSTICA - IBGE. Censo Agropecuário 2006. Disponível em:

http://www.cidades.ibge.gov.br/xtras/temas.php?lang=\&codmun=520060\&idtema=3\&search=goias |alto-paraiso-de-goias|censo-agropecuario-2006. Acesso em jan. 2014.

. Censo 2010. Disponível em

<http://www.ibge.gov.br/cidadesat/topwindow.htm?1> Acesso em 20 ago. 2012.

. Produção Agrícola Municipal 2012. Rio de Janeiro: IBGE, 2013. Disponível em: http://cidades.ibge.gov.br/xtras/temas.php?lang=\&codmun=520060\&idtema=122\&search=goias | alt o-paraiso-de-goias | lavoura-permanente-2012. Acesso em jan. 2013.

IRVING, Marta. A. Refletindo sobre o turismo como mecanismo do desenvolvimento local. Revista de Desenvolvimento Econômico. Salvador, Ano IV, n. 7, p. 69-74, dez. 2002.

IRVING, Marta de A., RODRIGUES, Camila G. O. e NEVES FILHO, Nilton C. Construindo um modelo de planejamento turístico de base comunitária - um estudo de caso. In: IRVING, Marta de A. e AZEVEDO, Julia. Turismo: o desafio da sustentabilidade. São Paulo: Futura, 2002, p. 93-112.

KAGEYAMA, Ângela. A. Desenvolvimento rural: conceitos e aplicação ao caso brasileiro. Porto Alegre: Editora da UFRGS, 2008.

. Desenvolvimento rural no Rio Grande do Sul. In: SCHNEIDER, Sérgio. (Org.). A diversidade da agricultura familiar. Porto Alegre: Editora da UFRGS, 2009, p. 245-272.

KUNTZ, Rolf. François Quesnay: Economia. Tradução Mary M. C. Neves et al. São Paulo: Ática, 1984.

LAVILLE, Christian.; DIONNE, Jean. A construção do saber: manual de metodologia da pesquisa em ciências humanas. Porto Alegre: Ed. Artes Médicas Sul; Belo Horizonte: Ed. UFMG, 1999.

LEFF, Enrique. A complexidade ambiental. Tradução - Eliete Wolff. São Paulo: Cortez, 2003.

Vozes, 2009. . Ecologia, capital e cultura: a territorialização da racionalidade ambiental. Petrópolis:

LEMOS, Leandro. O valor turístico na economia da sustentabilidade. São Paulo: Aleph, 2005.

LEVIN, Pablo. El capital tecnológico. Buenos Aires (Arg.): Editorial Catálogos, 1997. Disponível em: <http://www.econ.uba.ar/www/intitutos/economia/ceplad/publicaciones/siglo/101.htm> Acesso em: 18 jan. 2012.

LIMA, Ricardo B. de. Natureza: uma categoria do social. In: DUARTE, Laura M. G.; BRAGA, Maria L. S. (Orgs.) Tristes cerrados. Sociedade e biodiversidade. Brasília: Ed. Paralelo 15, 1998, p. 25-62.

LUCHIARI, Maria T. D. P. Turismo e território: sustentabilidade para quem? In: BARRETO, Margarita e TAMANINI, Elizabete (Orgs). Redescobrindo a ecologia no turismo. Caxias do Sul: EDUCS, 2002, p. 111125. 
MAIA, A. Gori.; ROMEIRO, Ademar R. Validade e confiabilidade do método do custo de viagem: um estudo aplicado ao Parque Nacional da Serra Geral. Revista Economia Aplicada, São Paulo, v.12, n.1, p.103-123, janeiro-março 2008.

MARSHALL, Alfred. Princípios de economia: tratado introdutório. Tradução Rômulo Almeida e Ottolmy Strauch - 2 ed. São Paulo: Nova Cultural, 1985.

MATTOS, Luciano; BRONDÍZIO, Eduardo; HERCOWITZ, Marcelo. Capital social e participação social na gestão de políticas públicas. In: MATTOS, L. \& HERCOWITZ, M. Economia do meio ambiente e serviços ambientais: estudo aplicado à agricultura familiar, às populações tradicionais e aos povos indígenas. Brasília: Embrapa Informação Tecnológica, 2011, p. 119-139.

MARTINS, Elias. Parque Nacional da Chapada dos Veadeiros - 50 anos (1961-2011). Brasília: MMA/ICMBio, 2011.

MARX, Karl. O capital: crítica da economia política: livro I. Tradução Reginaldo Sant'Anna - 18 ed. Rio de Janeiro: Civilização Brasileira, 2001.

MAY, Peter H. et al. Valoração econômica da biodiversidade no Brasil: revisão da literatura. In: ENCONTRO DA SOCIEDADE BRASILEIRA DE ECONOMIA ECOLÓGICA-ECO-ECO. III. 1999, Recife, Anais... Recife: 1999. Disponível em: <www.race.nuca.ie.ufrj.br/eco/trabalhos/mesa1/4.doc> Acesso em 20 maio 2012.

MAZZETTO SILVA, Carlos E. Ordenamento territorial no cerrado brasileiro: da fronteira monocultora a modelos baseados na sociobiodiversidade. Desenvolvimento e meio ambiente, Curitiba, n. 19, p. 89109, jan./jun. 2009. Disponível em:

<http://ojs.c3sl.ufpr.br/ojs/index.php/made/article/view/16407/10887> Acesso em 21 jul. 2013.

MEDEIROS, R. et al. Contribuição das unidades de conservação brasileiras para a economia nacional. Sumário Executivo. Brasília: UNEP-WCMC, 2011.

MENDES, Ana B. V. Conservação ambiental e direitos multiculturais: reflexões sobre justiça. 2009. Tese (Doutorado em Ambiente e Sociedade), Universidade Estadual de Campinas, Campinas: 2009. Disponível em: <http://www.bibliotecadigital.unicamp.br/document/?view=000449431> Acesso em 24 set. 2013.

MIKHAILOVA, Irina e BARBOSA, Francisco A. R. Valorando o capital natural e os serviços ecológicos de unidade de conservação: o caso do Parque Estadual do Rio Doce-MG, Sudeste do Brasil. Texto para discussão $n^{\circ}$ 230. Belo Horizonte: UFMG/Cedeplar, 2004. Disponível em <www.cedeplar.ufmg.br/pesquisas/td/TD\%20230.pdf> Acesso em 18 jan. 2010.

MIOR, Luiz C. Desenvolvimento rural: a contribuição da abordagem das redes sociais e sociotécnicas. In: SCHNEIDER, S. (Org.). A diversidade da agricultura familiar. Porto Alegre: Editora da UFRGS, 2009, p. 273-298.

Argos, 2005.

. A gricultores familiares, agroindústrias e redes de desenvolvimento rural. Chapecó: 
MIRANDA, Carlos L.; ADIB, Alberto R. Multifuncionalidade e desenvolvimento rural sustentável. Marco Social, Rio de Janeiro, n. 9, p. 8-11. Diponível em:

http://www.institutosouzacruz.org.br/groupms/sites/ins_8bfk5y.nsf/vwPagesWebLive/D08G4PXT/\$ FILE/medMD8G4QA4.pdf?openelement. Acesso em jun. 2014.

MUELLER, Charles C. Os economistas e as relações entre o sistema econômico e o meio ambiente. Brasília: Editora Universidade de Brasíla, 2012.

NELSON, Richard R.; WINTER, Sidney G. Uma teoria evolucionária da mudança econômica. Tradutor: Cláudio Heller. Campinas: Editora da UNICAMP, 2005.

NOGUEIRA, Jorge M. et al. Valoração econômica do meio ambiente: ciência ou empiricismo? Caderno de Ciência \& Tecnologia, Brasília, v.17, n.2, p. 81-115, mai/ago. 2000.

NOGUEIRA, Jorge M. e MEDEIROS, Marcelino A. A. Quanto vale aquilo que não tem valor? Valor de existência, economia e meio ambiente. Cadernos de ciência e tecnologia. Brasília, v. 16, n. 3, p. 59-83, set./dez. 1999. Disponível: <http://seer.sct.embrapa.br/index.php.cct/article/download/8905/5026> Acesso em 08 out. 2012.

NORDER, Luiz A. C. Mercantilização da agricultura e desenvolvimento territorial. In: SCHNEIDER, Sergio (Org.). A diversidade da agricultura familiar. Porto Alegre: Editora da UFRGS, 2009, p. 59-83.

NORGAARD, Richard. Valoração ambiental na busca de um futuro sustentável. Tradução Anatailde P. Crêspo. In: CAVALCANTI, Clóvis (Org.). Meio ambiente, desenvolvimento sustentável e políticas públicas. 3 ed. São Paulo: Cortez, Recife: Fundação Joaquim Nabuco, 2001. p. 83-92.

NOVAES, Pedro C. Da participação ao desenvolvimento: modernidade, cidadania e sustentabilidade na Chapada dos Veadeiros. 2002. Dissertação (Mestrado em Ciência Ambiental) Universidade de São Paulo. São Paulo: 2002.

NOVAES, Pedro C., LOBO, Fábio e FERREIRA, Manuel E. Pobreza, desenvolvimento e conservação da biodiversidade em Goiás. In: FERREIRA JÚNIOR, Laerte G. (Org.). A encruzilhada socioambiental: biodeiversidade, economia e sustentabilidade no cerrado. Goiânia: Editora da UFG, 2008, p. 127-149.

OLIVEIRA, Ivanilton J. Cartografia turística para a fruição do patrimônio natural da Chapada dos Veadeiros (GO). 2007. Tese (Doutorado em Geografia) Universidade de São Paulo. São Paulo, 2007.

OLIVEIRA, José R. História dos garimpos de cristal da Chapada dos Veadeiros. Goiânia: Kelps, 2009.

ORTEGA, Antônio C. e MENDONÇA, Nilton C. Estratégia de desenvolvimento territorial rural no Brasil: continuidades e rupturas. In: ORTEGA, Antonio C. e ALMEIDA FILHO, Niemeyer (Orgs.). Desenvolvimento territorial, segurança alimentar e economia solidária. Campinas: Editora Alínea, 2007, p. 93-121.

ORTIZ, Ramon A.; SEROA DA MOTTA, R.; FERRAZ, Claudio. Estimando o valor ambiental do Parque Nacional do Iguaçu: uma aplicação do método do custo de viagem. Texto para discussão. IPEA, Rio de Janeiro, janeiro 2001. 
ORTIZ, Ramon A. Valoração econômica ambiental. In: MAY, Peter H.; LUSTOSA, Maria C.; VINHA, Valéria. Economia do meio ambiente. Rio de Janeiro: Campus, 2003. p. 81-99.

OSTROM, Elinor. The governance challenge: matching institutions to the structure of social-ecological systems. In: TEIXEIRA, Erly C. e BRAGA, Marcelo J. Instituições e desenvolvimento econômico. Viçosa: Os Editores, 2007.

PAULILLO, Luiz F. Redes de poder \& territórios produtivos: indústria, citricultura e políticas públicas no Brasil do século XX. São Carlos: Rima: Editora da UFSCar, 2000.

PEARCE, David W. e TURNER, R. Kerry. Economics of natural resources and the environment. Baltimore: The Johns Hopkins University Press, 1990.

PEREIRA, Bárbara E. e DIEGUES, Antonio C. Conhecimento de populações tradicionais como possibilidade de conservação da natureza: uma reflexão sobre a perspectiva da etnoconservação. Desenvolvimento e meio ambiente, Curitiba, n. 22, p. 37-50, jul./dez. 2010. Disponível em: <http://ojs.c3sl.ufpr.br/ojs/index.php/made/article/view/16054/13504> Acesso em 16 jul. 2013.

PEREIRA, Eliane C. et al. Reservas particulares do patrimônio natural como zona de amortecimento do Parque Nacional da Chapada dos Veadeiros. Goiânia: NUPENGE/UCG, 2004. Disponível em <http://www2.ucg.br/nupenge/pdf/artigo004.pdf> Acesso em: 14 dez. 2012.

PÉREZ-NEBRA, Amália R. e TORRES, Cláudio V. Medindo a imagem do destino turístico: uma pesquisa baseada na teoria de resposta ao item. Revista RAC, Curitiba, v.14, n.1, art.5, p.80-99, jan./fev. 2010. Disponível em <http://www.scielo.br/pdf/rac/v14n1/06.pdf> Acesso em: 23 ago. 2012.

PIMBERT, Michel P. e PRETTY, Jules N. Parques, comunidades e profissionais: incluindo "participação" no manejo de áreas protegidas. In: DIEGUES, Antonio C. (Org.). Etnoconservação: novos rumos para a conservação da natureza. São Paulo: NUPAUB/USP, 2000, p. 183-223.

PINDYCK, Robert S.; RUBINFELD, Daniel L. Microeconomia. São Paulo: Prentice Hall, 2002.

PIRES, André. Um sentido dentre outros possíveis: o rural como representação. In: CAMPANHOLA, C. \& GRAZIANO DA SILVA, J. O novo rural brasileiro: novas ruralidades e urbanização. Brasília: Embrapa Informação Tecnológica, 2004, p. 149-174.

PREFEITURA MUNICIPAL DE ALTO PARAíSO DE GOIÁS. Plano Diretor Ambiental/Urbano. Alto Paraíso de Goiás, 1998. Disponível em: <www.alto.paraiso.nom.br/aparaiso/solos.htm> Acesso em: 17 out. 2011.

RIBEMBOIM, Jacques A. Valoração monetária do uso direto de parques nacionais e o caso da Chapada dos Veadeiros. 2000. Tese (Doutorado em Economia), Universidade Federal de Pernambuco. Recife, 2000.

RIBEMBOIM, Jacques A. População visitante e local: efeitos na dinâmica econômico-ambiental e valoração monetária do Parque Nacional da Chapada dos Veadeiros. In:

ENCONTRO NACIONAL DE ESTUdOS POPULACIONAIS, ABEP. XIV. 2004. Caxambú-MG. Anais... Caxambú: 2004. Disponível em: 
<www.abep.nepo.unicamp.br/site_eventos_abep/PDF/ABEP2004_123.pdf> Acesso em: 23 nov. 2009.

RICARDO, David. Princípios de economia política e de tributação. Tradução Maria A. Ferreira. Lisboa: Fundação Calouste Gulbenkian, 1965.

ROCHA, Genival F. et al. Detecção de desmatamentos no bioma cerrado entre 2002 e 2009: padrões, tendências e impactos. RBC. Revista Brasileira de Cartografia (Online), v. 63, p. 341-349, 2011. Disponível em: http://www.lapig.iesa.ufg.br/lapig/index.php/produtos/publicacoes/viewdownload/8periodicos/517-deteccao-de-desmatamentos-no-bioma-cerrado-entre-2002-e-2009-padroestendencias-e-impactos. Acesso em jun. 2014.

ROCKTAESCHEL, Benita M.M.M. Terceirização em áreas protegidas: Estímulo ao ecoturismo no Brasil. São Paulo: Editora Senac, 2006.

RODRIGUES, Camila G. O. e GODOY, Larissa R C. Atuação pública e privada na gestão de Unidades de Conservação: aspectos socioeconômicos da prestação de serviços de apoio à visitação em parques nacionais. Desenvolvimento e meio ambiente, Curitiba, v. 28, p. 75-88, jul./dez. 2013. Disponível em: <http://ojs.c3sl.ufpr.br/ojs2/index.php/made/article/viewFile/31280/21658> Acesso em: 10 jul. 2013.

RODRIGUES, Camila G. O. O turismo e a reconstrução do espaço rural. In: CARNEIRO, M J. (Org.). Ruralidades contemporâneas: modos de viver e pensar o rural na sociedade brasileira. Rio de Janeiro: Mauad X: FAPERJ, 2012, p. 227-246.

RODRIGUES, Waldecy e FREDRYCH, Thelma V. O dilema das comunidades tradicionais em unidades de conservação: o caso da comunidade Mumbuca no Parque Estadual do Jalapão (TO). Boletim Goiano de Geografia, Goiânia, v. 33, n. 3, p. 63-79, et./dez. 2013. Disponível em:

<http://www.revistas.ufg.br/index.php/bgg/article/view/27331/15605> Acesso em: 02 set. 2013.

ROMEIRO, Ademar R. Economia e biodiversidade. Revista Megadiversidade - Desafios econômicos para a conservação ambiental, Belo Horizonte: vol. 2, n.1-2, p.7-9, 2006.

ROZO, Edna. El turismo sustentable como promotor del desarrollo de las comunidades locales. In: KRUMHOLZ, Daniel M. Turismo e desarollo sostenible. Bogotá: Universidad Externado de Colombia. 2002. p.123-140.

SACHS, Ignacy. Ecodesenvolvimento: crescer sem destruir. São Paulo: Vértice, 1986.

SANTOS, Milton. Espaço e método. 4. ed. São Paulo: Nobel, 1997.

SARAIVA, Regina C. F. Saberes, fazeres e natureza nas vozes de mulheres da Chapada dos Veadeiros Goiás. Revista História Oral, v. 1, n. 15, p. 209-229, jan./jun. 2012. Disponível

em:

<http://revista.historiaoral.org.br/index.php?journal=rho\&page=article\&op=view\&path\%5B\%5D=24 8\&path\%5B\%5D=283> Acesso em: 07 ago. 2012. 
SCHNEIDER, Sérgio. et al. (2009) A pluriatividade e as condições de vida dos agricultores familiares do Rio Grande do Sul. In: Schneider, S. (Org.). A diversidade da agricultura familiar. Porto Alegre: Editora da UFRGS, 2009, p. 139-166.

SEABRA, Giovanni. Educação ambiental: conceitos e aplicações. In: SEABRA, Giovanni (Org.). Educação ambiental: conceitos e aplicações. João Pessoa: Editora da UFPB, 2013, p. 15-33.

. Natureza, cultura e turismo em unidades de conservação. In: PORTUGUEZ, Anderson P. et al. (Orgs.). Turismo, espaço e estratégias de desenvolvimento local. João Pessoa: Editora da UFPB, 2012.

2001.

. Ecos do turismo: o turismo ecológico em áreas protegidas. Campinas: Papirus,

Do garimpo aos ecos do turismo: o Parque Nacional da Chapada Diamantina. 1998. Tese (Doutorado em Geografia), Universidade de São Paulo. São Paulo, 1998.

SEBOLD, Sérgio e DJALMA DA SILVA, Aparecido. Uma aplicação do método dos custos de viagem para valoração de um parque ambiental. Revista Produção, Florianópolis, v.4, n.3, p.1-15, agosto 2004. Disponível em <www.producaoonline.org.br/rpo/article/download/312/412> Acesso em: 18 mar. 2012.

SEROA DA MOTTA, Ronaldo. Manual para valoração econômica de recursos naturais. Rio de Janeiro: IPEA/MMA/PNUD/CNPq, 1997. Disponível em:

<http://www.em.ufop.br/ceamb/petamb/cariboost_files/manual_20serroa_20motta.pdf> Acesso em: 28 mar. 2012.

SHENG, Fulai. Valores em mudança e construção de uma sociedade sustentável. Tradução Norma Gerjoy. In: CAVALCANTI, Clóvis (org.). Meio ambiente, desenvolvimento sustentável e políticas públicas. 3. ed. São Paulo: Cortez: Recife: Fundação Joaquim Nabuco, 2001. p.165-178.

SILVA, Clarinda A. Parques nacionais: elementos para um turismo desejável. Cadernos temáticos, Brasília, n. 7, p. 38-43, dez. 2005. Disponível em:

<http://portaldoprofessor.mec.gov.br/storage/materiais/0000013542.pdf> Acesso em: 30 jun. 2013.

Paisagem e paisagens do Parque Nacional da Chapada dos Veadeiros: o olhar dos "de dentro" e "dos de fora". Observatório geográfico de Goiás, Goiânia, 2004. Disponível em: <http://observatoriogeogoias.iesa.ufg.br/uploads/215/original_Silva_clarinda_aparecida_paisagem_ paisagens.pdf> Acesso em: 26 jun. 2013.

Paisagem - campo de visibilidade e de significação sociocultural: Parque Nacional da Chapada dos Veadeiros e Vila de São Jorge. 2003. Dissertação (Mestrado em Geografia), Instituto de Estudos Sócio-Ambientais, Universidade Federal de Goiás. Goiânia, 2003a.

. Parque Nacional da Chapada dos Veadeiros: o olhar dos "de dentro" e dos "de fora". In: ALMEIDA, Maria G (Org.). Paradigmas do turismo. Goiânia: Alternativa, 2003b, p. 71-85. 
SMITH, Adam. Uma investigação sobre a natureza e causa da riqueza das nações. Tradução Norberto de Paula Lima. Rio de Janeiro: Ediouro, 1986.

SWARBROOKE, John e HORNER, S. O comportamento do consumidor no turismo. Tradução de Saulo Krieger - São Paulo: Aleph, 2002.

VAN DER PLOEG, Jan D. O modo de produção camponês revisitado. In: SCHNEIDER, Sergio (Org.). A diversidade da agricultura familiar. Porto Alegre: Editora da UFRGS, 2009, p. 15-56.

VEIGA, J. E. Sustentabilidade: a legitimação de um novo valor. São Paulo: Editora Senac SP, 2010.

Garamond, 2008.

Desenvolvimento sustentável: o desafio do século XXI. Rio de Janeiro: Editora - Do crescimento agrícola ao desenvolvimento rural. In: CASTRO, Ana C. Desenvolvimento em debate. Rio de Janeiro: Ed. Mauad/BNDES, 2002, p. 383-409. Disponível em:

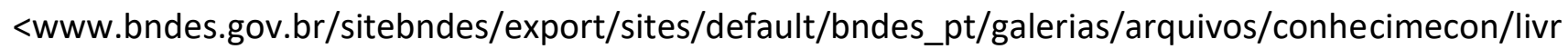
o_debate/3-desenvolvimento rural.pdf> Acesso em: 13 dez. 2010.

WANDERLEY, Maria. N. B. Prefácio. In: CARNEIRO, Maria. J. (Org.). Ruralidades contemporâneas: modos de viver e pensar o rural na sociedade brasileira. Rio de Janeiro: Mauad X: FAPERJ, 2012, p. 1517.

YIN, Robert K. Estudo de caso: planejamento e métodos. 2. Ed. Porto Alegre: Bookman, 2001.

YOUNG, Carlos E. F. e FAUSTO, José R. B. Valoração de recursos naturais como instrumento de análise da expansão da fronteira agrícola na Amazônia. Texto para discussão $n^{\circ} 490$. In: ENCONTRO DA SOCIEDADE BRASILEIRA DE ECONOMIA ECOLÓGICA. I. 1996. Campinas/Águas de Lindóia. Anais... Campinas/Águas de Lindóia, 1996. 


\section{Roteiro moradores}

$\rightarrow$ Relação do indivíduo com o meio ambiente:

- $\quad$ resgate de sua forma de instalação na localidade;

- $\quad$ relação com o lugar;

- $\quad$ atividades exercidas - garimpagem/extrativismo/agricultura;

- $\quad$ de quem eram as terras?

$\rightarrow$ Contexto sócio/econômico/ambiental

- $\quad$ qual a atividade que mais pesava na formação da renda? (garantia o sustento);

- $\quad$ como funcionava(m) a(s) atividade(s);

- $\quad$ quais elementos (pessoas) davam suporte para a atividade?

- $\quad$ como se adquiria material de trabalho (ferramentas, insumos)?

- a quem de destinava o produto do trabalho?

- como funcionava o comércio do produto? (existência de intermediários)

- $\quad$ existia alguma organização das pessoas?

- $\quad$ qual o relacionamento social entre as pessoas (festas, mutirões, grupos de ajuda familiar ou extra-familiar);

- $\quad$ existia alguma fiscalização? Quem controlava as atividades?

- $\quad$ a sua atividade "marcava" muito o ambiente?

$\rightarrow$ Contexto espaço-temporal das atividades

- descrição das atividades antes e depois da criação do PNCV;

- $\quad$ com a criação do PNCV, qual a sua atividade principal?

- $\quad$ com o PNCV, o que mudou na sua atividade?

- $\quad$ a criação do PNCV representou uma mudança no modo de viver das pessoas?

- $\quad$ quais oportunidades o PNCV trouxe para as pessoas da Vila;

- $\quad$ qual a relação das pessoas do local com a administração do PNCV?

- $\quad$ o que o PNCV e seus "recursos" representam para as pessoas do lugar;

- $\quad$ que valores você atribui a esse conjunto de recursos? 


\section{Roteiro condutores de visitantes (guias)}

$\rightarrow$ Relação indivíduo/ambiente

- $\quad$ relação com o lugar: nativo ou de fora?

- $\quad$ qual atividade antes de ser condutor

- tem outra atividade?

- $\quad$ mora no Distrito?

- $\quad$ pertence a alguma associação?

$\rightarrow$ Questões sócio/econômico/ambientais

- $\quad$ processo de qualificação

- a atividade é suficiente para garantir a sobrevivência?

- qual o papel dos condutores em relação à conservação dos "recursos" do PNCV?

- $\quad$ qual a relação dos condutores e suas organizações com a administração do PNCV?

- qual a relação dos condutores com os donos de pousadas, restaurantes e estabelecimentos comerciais do distrito?

- $\quad$ qual o papel do condutor no processo do ecoturismo do $\mathrm{PNCV}$ e região?

- $\quad$ o que o PNCV e seus "recursos" representam para as pessoas do lugar?

- que valores você atribui a esse conjunto de "recursos"? 


\section{Roteiro - donos de pousadas/ áreas de camping/ restaurantes}

$\rightarrow$ Relação indivíduo/ambiente

- $\quad$ relação com o lugar: nativo ou de fora?

- qual atividade exercia antes de ser dono de pousada?

- $\quad$ exerce outra atividade?

- faz parte de alguma organização do distrito?

- $\quad$ quais as dificuldades/oportunidades de ser dono de um estabelecimento ligado ao turismo em São Jorge?

$\rightarrow$ Questões sócio/econômica/ambientais

- $\quad$ processos de qualificação para a atividade

- a atividade é suficiente para garantir a sobrevivência?

- qual o papel dos donos de estabelecimentos no processo do ecoturismo no PNCV e região?

- qual o tipo de relacionamento dos donos de estabelecimento com os turistas?

- qual a relação dos donos de estabelecimento com a administração local e municipal?

- $\quad$ qual a relação dos donos de estabelecimento com a administração do PNCV?

- qual o papel dos donos de estabelecimentos em relação à conservação dos bens e serviços ambientais do PNCV e região?

- $\quad$ qual a relação entre os donos de estabelecimentos

* pousadas e restaurantes/comércio

* pousadas de nativos e de fora

- o que o PNCV e seus "recursos" representam para as pessoas do lugar?

- que valores você atribui a esse conjunto de "recursos"? 


\section{Roteiro donos de propriedades particulares}

$\rightarrow$ Relação indivíduo/ambiente

- $\quad$ relação com o lugar: nativo ou de fora?

- $\quad$ qual atividade exercia (ou exerce) antes de ser dono de propriedade?

- $\quad$ faz parte de alguma organização?

- quais são as dificuldades/oportunidades de ser dono de uma propriedade com "recursos naturais" em São Jorge e mediações?

- $\quad$ qual a relação com a terra (dono/posseiro/arrendatário)?

$\rightarrow$ Questões sócio/econômico/ambientais

- $\quad$ essa atividade é a principal para a formação da renda? Proporciona o seu sustento?

- $\quad$ como funciona(m) a(s) atividade(s)?

- $\quad$ antes de exercer essa atividade, o que se fazia na propriedade?

- $\quad$ se exercia atividade agrícola, o que explorava: plantação, pecuária, outro.

- $\quad$ exploram alguma atividade extrativista (plantas)?

- $\quad$ com a criação do PNCV, que restrições vieram?

- $\quad$ qual a relação dos proprietários com os turistas?

- $\quad$ qual a relação dos proprietários com os administradores do PNCV?

- vocês recebem algum incentivo (de governos) para conservar os "recursos naturais" das propriedades?

- $\quad$ qual a relação com os condutores de visitantes?

- qual a relação com os donos de pousadas/estabelecimentos comerciais de São Jorge?

- $\quad$ o que o PNCV e seus "recursos" representam para as pessoas do lugar?

- que valores você atribui a esse conjunto de "recursos"? 


\section{Roteiro administradores locais}

$\rightarrow$ Relação indivíduo/ambiente

- $\quad$ relação com o lugar: nativo ou de fora?

- $\quad$ que atividades exercia (ou exerce) em paralelo com a da administração?

$\rightarrow$ Questões sócio/econômico/administrativo/ambientais

- como é a forma de se chegar ao cargo: eleito? duração? atribuições? remunerado?

- qual o papel do administrador junto à localidade e às pessoas?

- $\quad$ quais os aspectos de natureza administrativa mais relevantes no Distrito? (antes e depois do PNCV)

- $\quad$ qual a sua visão da ambiência do Distrito? (antes e depois do PNCV)

- qual as principais demandas do Distrito?

- $\quad$ quais os principais aparelhos urbanos do Distrito? (infra-estrutura)

- $\quad$ qual a capacidade de carga do Distrito?

* capacidade de alojamento;

* número de pousadas/campings

- qual a relação da administração local com a administração municipal? do PNCV? com as organizações locais e extra-locais (ONGs nacionais e estrangeiras, governos estrangeiros)

- quais as ações para integração das atividades do PNCV com as atividades desenvolvidas no Distrito?

- qual a importância da atividade turística para as pessoas do Distrito?

- $\quad$ o que o PNCV e seus "recursos" representam para as pessoas do lugar?

- que valores você atribui a esse conjunto de "recursos"? 


\section{Roteiro: Administração do Parque Nacional (PN)}

1 - Instalação do Parque Nacional

- Como se deu o processo de instalação do PN?

- Qual a situação em relação a posse das terras na área do PN quando da sua instalação?

- De quem eram essas terras?

- Houve um processo de desapropriação ou similar?

- Se houve tal processo, como foi feito o ressarcimento das terras?

- Existiu ou existe na região conflitos em relação à posse da terra? (mesmo que seja em áreas adjacentes ao PN)

- Como o IBAMA/ICMBio tratou e trata essas questões relacionadas à posse da terra na região?

- Porque houve uma variação na dimensão do PN, ao longo dos anos, desde a sua criação?

- Houve alguma "pressão" por parte dos donos de terra para a ocorrência dessa variação?

2 - Distribuição das terras na região

- Como se dá a distribuição da terra no entorno do PN?

- Qual o percentual de pequenas, médias e grandes propriedades na região do entorno do PN?

- Qual o módulo rural do município de Alto Paraíso?

- Qual a realidade da exploração agropecuária no município de Alto Paraíso e entorno do PN?

3 - Zona de amortecimento

- A chamada "zona de amortecimento" tem um respaldo legal? Como está a situação atualmente?

- Qual a relação do IBAMA/ICMBio com os proprietários rurais da zona de amortecimento ao longo do tempo, desde a criação do PN?

- Quais eram as atividades praticadas na terra antes e depois da criação do PN?

- Atualmente como andam essas atividades?

- Existe uma pressão dos proprietários de terra para a exploração agrícola na zona de amortecimento?

- Com o advento do ecoturismo na região, houve um redirecionamento das atividades no entorno do PN? 
- As propriedades rurais, para exercerem atividade turística, precisam de algum cadastro/registro?

- Existe um controle do número de propriedades rurais no entorno do PN?

- Na região de São Jorge, quantas são as propriedades rurais?

- Para o exercício da atividade agropecuária nas propriedades rurais da zona de amortecimento, é necessário algum tipo de licença?

- Que atividades mais ameaçavam a integridade da biodiversidade do PN?

- Como é o relacionamento da direção do PN com os proprietários rurais do entorno do PN?

- Há alguma orientação técnica, parcerias, projetos em conjunto? 


\section{Roteiro: Administração Municipal}

1 - Geral

- Qual a vocação econômica do município?

- Principais atividades desenvolvidas (peso nas contas do município de cada uma delas).

- Importância da agropecuária (Secretaria de Agricultura).

- Importância do turismo (Secretaria de Turismo).

- Distribuição da propriedade de terra no município - grande, média, pequena propriedade (módulo rural de Alto Paraíso).

- Propriedades no entorno do PN (características).

- Multifuncionalidade da agricultura - turismo (ecoturismo e turismo rural).

- Existe alguma política de compensação para os proprietários que têm áreas de preservação?

- O município recebe algum benefício? (compensações)

- Apoio dos governos Estadual e Federal.

\section{2 - Distrito de São Jorge}

- Relação da administração municipal com o Distrito.

- Representação da administração municipal no Distrito.

- Ações da administração na localidade.

- Projetos, programas, parcerias no local.

- Relação com os proprietários rurais da região.

- O fato do Distrito estar praticamente no interior do PN exige medidas especiais? (expansão, abastecimento, esgoto, lixo).

\section{3 - Parque Nacional}

- Relação com a administração do PN.

- Parcerias

- Compensações em função da existência do PN.

- Questões fundiárias resolvidas ou por resolver.

- Zona de amortecimento no município - conflitos com os produtores rurais. 


\section{Roteiro: Instituições EMATER/AGRODEFESA}

- Aptidão econômica do município.

- Atividade agrícola:

- principais explorações;

- peso de cada uma delas;

- importância socioeconômica.

- Propriedades agrícolas:

- relação com a terra;

- divisão das propriedades (grande, média, pequena);

- módulo rural;

- programas governamentais;

- incentivos e compensações.

- Propriedades agrícolas no entorno do Parque Nacional

- regulamentação das propriedades;

- restrições das atividades agrícolas;

- parcerias com o PN para desenvolvimento de atividades;

- ecoturismo/turismo em áreas rurais.

- Relação com o PN

- política da aproximação - treinamento, atuação em conjunto;

- cadastramento de propriedades no limite do PN;

- direcionamento das atividades desenvolvidas. 


\section{Universidade Federal de Goiás - PRPPG/Ciências Ambientais Valoração Ambiental do Parque Nacional da Chapada dos Veadeiros por Intermédio do Método do Custo de Viagem. \\ Questionário}

Caso não queira responder este questionário neste momento, por favor, indique um local e horário para respondê-lo posteriormente.

Pousada: Horário:

Este questionário tem por objetivo obter informações básicas para subsidiar uma valoração do conjunto de bens ambientais que constituem o PNCV. As respostas obtidas terão tratamento estatístico, diluindo-se tais informações no universo pesquisado, mantidas sob reserva e discrição, bem como o sigilo de sua identidade.

1) Data:

Cidade:

2) Proveniência - Estado: Distância do PNCV: $\mathrm{Km}$

3) Dados pessoais: Sexo: $M($ ) $F($ )

$$
\begin{aligned}
& \text { Idade: ( ) menor de } 16 \text { anos ( ) entre } 16 \text { e } 25 \text { anos } \\
& \text { ( ) entre } 26 \text { e } 35 \text { anos ( ) entre } 36 \text { e } 45 \text { anos } \\
& \text { ( ) entre } 46 \text { e } 60 \text { anos ( ) mais que } 61 \text { anos } \\
& \text { ( ) graduação ( ) outros }
\end{aligned}
$$

Especificar área:

Profissão:

4) Motivos da viagem (passeio)

( ) turismo ( ) retiro/reflexão ( ) trabalho ( ) outros. Especificar:

5) Você está viajando: ( ) sozinho ( ) cônjuge/companheiro(a)

Quantas pessoas:

$$
\text { ( ) família (filhos, pais) ( ) outros }
$$

Meio de locomoção: ( ) automóvel ( ) ônibus ( ) avião ( ) outros

Tempo da viagem: Trajetória: No local:

6) Assinalar as alternativas que correspondem ao seu caso:
( ) A visita ao Parque é o principal motivo da viagem.
( ) A visita ao Parque faz parte de um roteiro da viagem. Qual?
( ) A visita ao Parque foi motivada pela vontade de outra pessoa.
( ) É a primeira vez que visita o Parque.
( ) Já visitou o Parque outras vezes. Quantas:
( ) Já visitou outros Parques dessa natureza.

7) Pagamento pela visita ao Parque - taxa do guia

( ) barata ( ) mediana ( ) cara

Sobre o guia - serviço: ( ) normal ( ) especial - Por quê?

Você acha que o Parque deveria cobrar uma taxa de visita? ( ) sim ( ) não Até quanto você estaria disposto a pagar para visitar o Parque? R\$

8) Gastos com a viagem:

Transporte: R\$

Alimentação: R\$ 
Hospedagem: R\$

Atrativos: R\$

Equipamentos: R\$

Lembranças/produtos locais: R\$

Outros: R\$

9) Renda Pessoal: ( ) até 2 salários mínimos ( ) de 2 a 5 salários mínimos

( ) de 5 a 10 salários mínimos ( ) mais de 10 salários mínimos

10) Renda Familiar: ( ) até 4 salários mínimos

( ) de 4 a 10 salários mínimos

( ) mais de 10 salários mínimos

11) O porquê da viagem? Resumir em uma expressão ou frase.

Valeu a pena pagar esses valores por esse passeio?

Além dos valores monetários, que valores mais você atribui a esse passeio?

\section{Obrigado!}




\section{APÊNDICE C: QUESTIONÁRIO DA PESQUISA DE CAMPO}

Universidade Federal de Goiás - UFG - PRPPG/Doutorado - Ciências Ambientais Pesquisa de Valoração Ambiental do Parque Nacional da Chapada dos Veadeiros por Intermédio do Método do Custo de Viagem.

Doutorando: Carlos Shiley Domiciano

Orientadora: Prof ${ }^{a}$. Dr ${ }^{a}$. Francis Lee Ribeiro

Este questionário tem por objetivo obter informações básicas para subsidiar uma valoração monetária do conjunto de bens ambientais que constituem o PNCV. As respostas obtidas terão tratamento estatístico, diluindose no universo pesquisado, mantidas sob reserva e discrição, bem como o sigilo de sua identidade. Por favor, indique um local e horário caso queira responder o questionário posteriormente. Pousada: Horário:

1) Data: _/ / 2012. Início:

2) Proveniência - Estado: Cidade:

Final:

3) Dados pessoais: Sexo: $\overline{\mathrm{F}(\mathrm{)}} \mathrm{M}(\mathrm{)}$

Idade: ( ) menor de 16 anos ( ) entre 16 e 25 anos ( ) entre 26 e 35 anos

( ) entre 36 e 45 anos ( ) entre 46 e 60 anos ( ) mais que 61 anos

Escolaridade: ( ) ensino fundamental ( ) ensino médio ( ) graduação ( ) outros Especificar área: Ocupação:

4) Motivos da viagem (passeio)

( ) turismo ( ) retiro/reflexão ( ) trabalho ( ) outros. Especificar:

( ) É o principal motivo da viagem.

( ) Faz parte de um roteiro da viagem. Qual?

( ) É a primeira vez que visita o Parque.

( ) Já visitou o Parque outras vezes. Quantas:

( ) Já visitou outros Parques dessa natureza.

5) Você está viajando: ( ) sozinho ( ) cônjuge/companheiro(a)

( ) familia (filhos, pais) ( ) outros. Quantas pessoas:

Meio de locomoção: ( ) automóvel ( ) ônibus ( ) avião ( ) outros

Tempo da viagem e permanência no local:

6) Pagamento pela visita ao Parque - taxa do condutor (especificar valor)

( ) barata ( ) mediana ( ) cara $\quad \mathrm{N}^{\circ}$ de pessoas no grupo:

Você acha que o Parque deveria cobrar uma taxa de visita? ( ) sim ( ) não

Até quanto você estaria disposto a pagar para visitar o Parque? R\$

7) Gastos com a viagem:

Transporte:R\$_Alimentação:R\$

R\$_ Produtos Locais: R\$_ Outros: R\$

Atrativos:R\$

Hospedagem:

8) Renda Pessoal em Salários Mínimos (SM):

( ) até $2 \mathrm{SM} \mathrm{(} \mathrm{)} \mathrm{de} 2$ a $5 \mathrm{SM} \mathrm{(} \mathrm{)} \mathrm{de} 5$ a $10 \mathrm{SM}$ ( ) acima de $10 \mathrm{SM}$

9) Renda Familiar em Salários Mínimos (SM):

( ) até $4 \mathrm{SM} \mathrm{(} \mathrm{)} \mathrm{de} 4$ a $10 \mathrm{SM}$ ( ) acima de $10 \mathrm{SM}$

10) O porquê da viagem? Resumir em uma expressão ou frase.

Além dos valores monetários, que valores mais você atribui a esse passeio? 
Universidade Federal de Goiás - PRPPG/Ciências Ambientais

Pesquisa de Valoração Ambiental do Parque Nacional da Chapada dos Veadeiros por Intermédio do Método do Custo de Viagem

Doutorando: Carlos Shiley Domiciano

Orientadora: Prof ${ }^{a}$. Dr ${ }^{a}$. Francis Lee Ribeiro

CONSENTIMENTO DA PARTICIPAÇÃO DA PESSOA COMO SUJEITO DA PESQUISA

$\mathrm{Eu}$,

RG: abaixo assinado, concordo em participar da pesquisa

Valoração Ambiental do Parque Nacional da Chapada dos Veadeiros por Intermédio do Método do Custo de Viagem, como sujeito. Fui devidamente informado(a) e esclarecido(a) pelo pesquisador sobre o estudo, seus objetivos, procedimentos nele envolvidos e a garantia de privacidade dos participantes, evidenciando que providências serão tomadas para preservar a minha identidade pessoal na divulgação dos resultados e publicação do trabalho.

Alto Paraíso de Goiás, de de 2012. 
Formulação estatística, para a determinação da amostra baseada na estimativa de uma proporção populacional (CASTRO NETO, 2004).

$$
n=\frac{N \cdot \hat{p} \cdot \hat{q} \cdot\left(Z_{\alpha / 2}\right)^{2}}{\hat{p} \cdot \hat{q} \cdot\left(Z_{\alpha / 2}\right)^{2}+(N-1) \cdot E^{2}}
$$

Sabendo-se que:

n-amostra

$\mathrm{N}$ - população (19891- número médio de visitantes de 2006-2011)

$\mathrm{p}$ - proporção de indivíduos da categoria $(50 \%=0,5)$

$\mathrm{q}$ - proporção de indivíduos não pertencentes à categoria $(50 \%=0,5)$

$(\mathrm{Z} . \alpha / 2)=1,96$ - valor crítico do intervalo de confiança a $95 \%$

$\mathrm{E}$ - margem de erro $(5 \%=0,05)$.

Aplicando-se a fórmula:

$\mathrm{n}=19891 \cdot 0,5 \cdot 0,5 \cdot(1,96)^{2} / 0,5 \cdot 0,5 \cdot(1,96)^{2}+(19891-1) \cdot 0,05^{2}=376,89 \approx 377$

$\mathrm{n}=377$ 


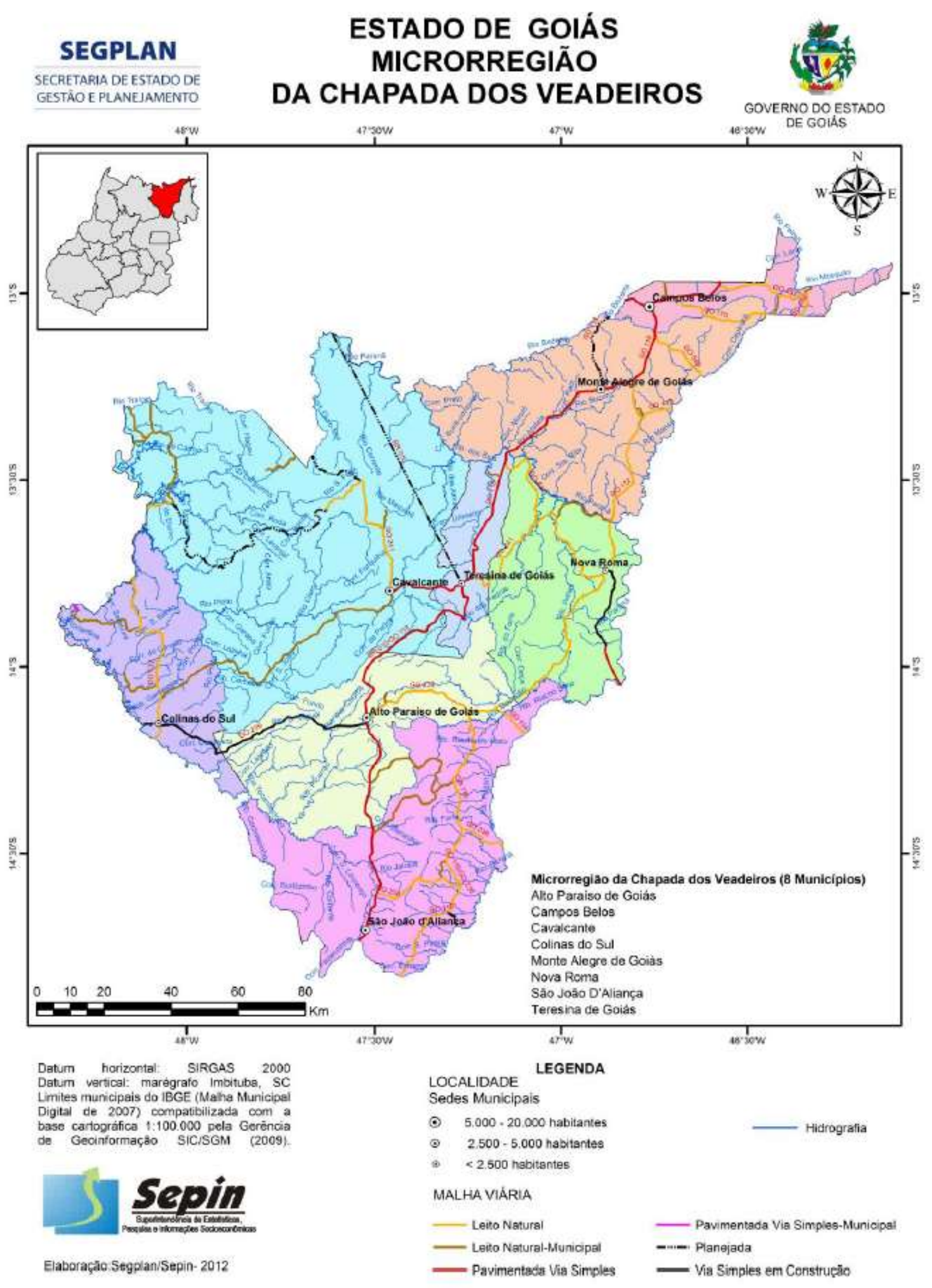


ANEXO B: ÁREAS DO PNCV CONFORME OS DECRETOS DE SUA REGULAMENTAÇÃO
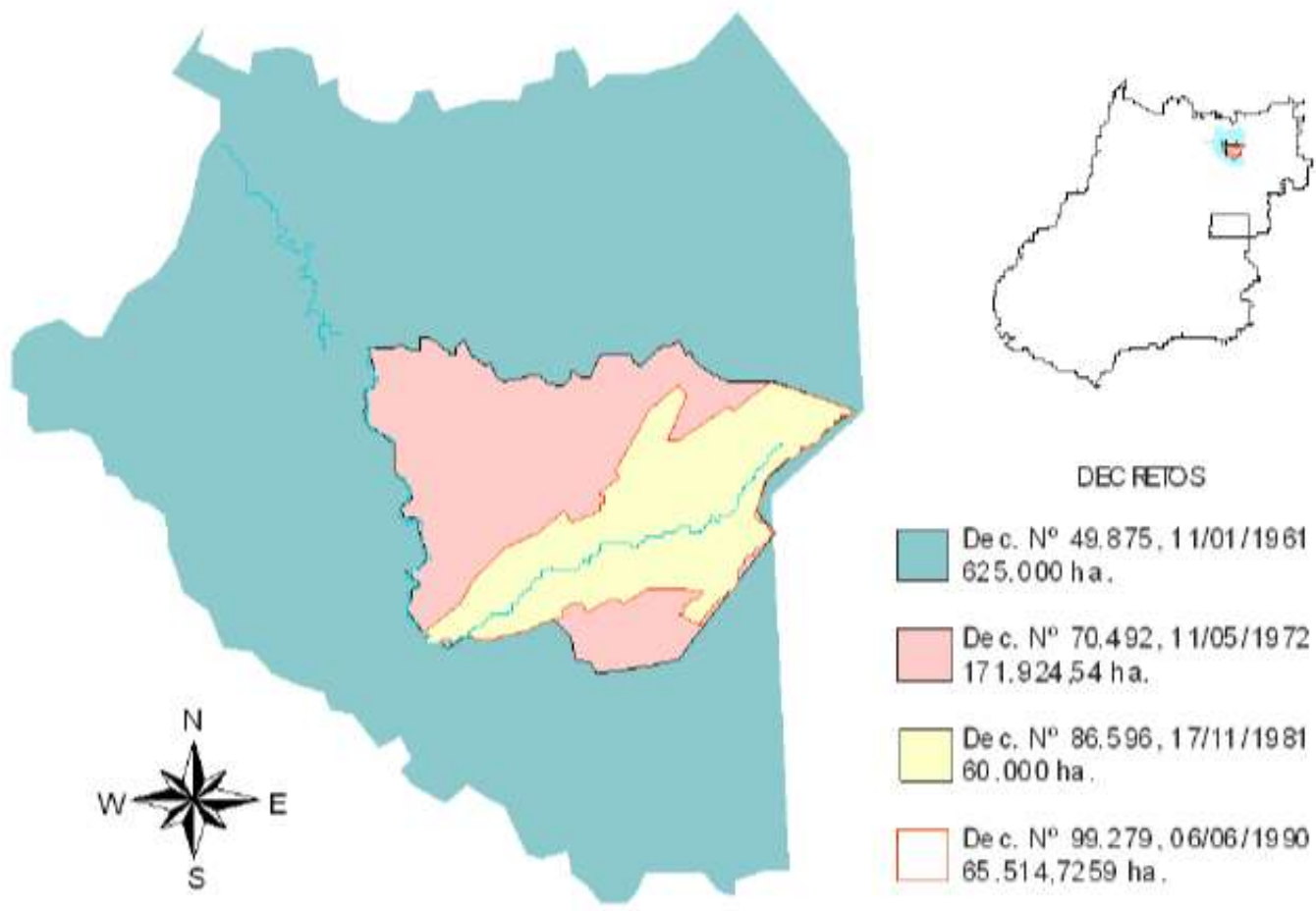

Dec. $N^{\circ} 49.875,11 / 01 / 1961$ 625.000 ha.

Dec. $N^{\circ} 70,492,11 / 05 / 1972$ 171.92454 ha.

Dec. $N^{\circ} 86,596,17 / 11 / 1981$ 60,000 ha

De c. $N^{\circ} 99,279,06 / 06 / 1990$ $65,514,7259$ ha.

Fonte: Brasil (2009) 